\title{
Species-Specific Effects on the Carbon and Nitrogen Cycle in Temperate Deciduous Forest
}

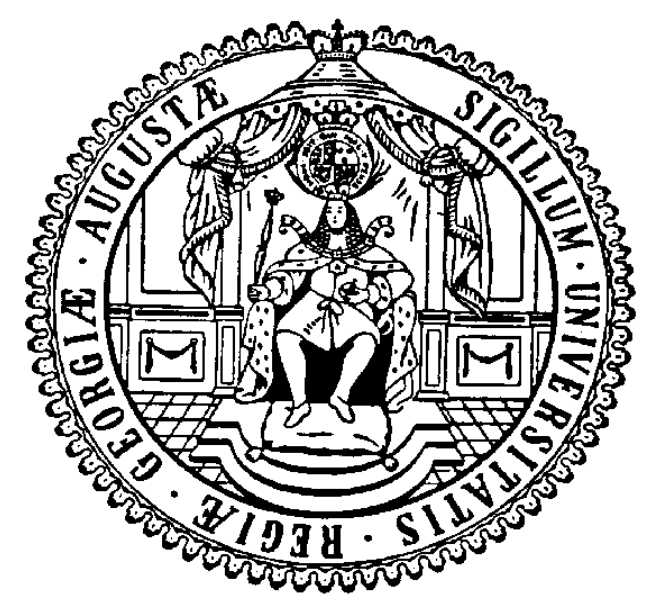

Dissertation

for the award of the degree "Doctor rerum naturalium" (Dr.rer.nat.)

of the Georg-August-University Göttingen

within the doctoral program Biodiversity and Ecology of the Georg-August University School of Science (GAUSS)

\author{
submitted by \\ Janine Sommer \\ from Querfurt \\ Göttingen, October 2016
}




\section{Betreuungsausschuss}

Prof. Dr. Yakov Kuzyakov, Ökopedologie der gemäßigten Zonen, Georg-August Universität, Göttingen

Prof. Dr. Prof. Dr. Andrea Carminati, Devision of Soil Hydrology, Georg-August Universität, Göttingen

Prof. Dr. Christian Ammer, Silviculture and Forest Ecology of the Temperate Zone, Georg-August Universität, Göttingen

\section{Mitglieder der Prüfungskommission}

Referent: Prof. Dr. Hermann Behling, Department of Palynology and Climate Dynamics, Georg-August Universität, Göttingen

Korreferent: Prof. Dr. Bergmeier, Vegetation Analysis \& Plant Diversity Georg-August Universität, Göttingen

2. Korreferent: Christoph Scherber, Research Group Animal Ecology and multitrophic interactions, University Münster

Tag der mündlichen Prüfung: 02.12.2016 


\section{Table of Content}

TABLE OF CONTENT

SUMMARY

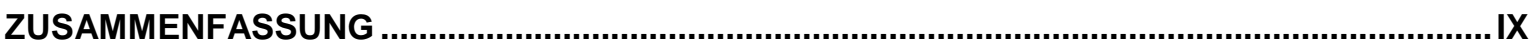

LIST OF FIGURES

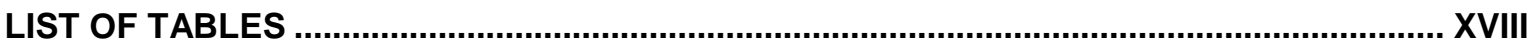

ABBREVIATIONS

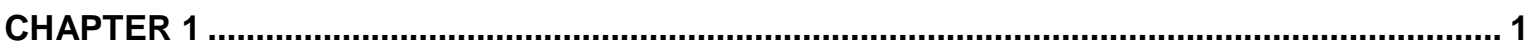

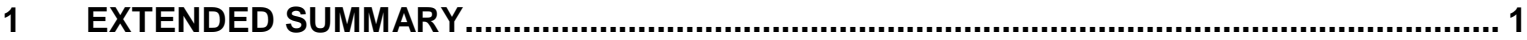

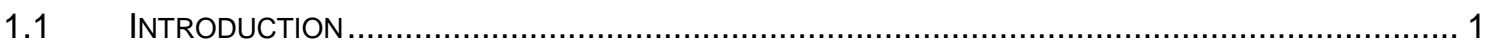

1.1.1 The link between biodiversity and ecosystem functioning ..................................... 1

1.1.2 The species effects on the $C$ and nutrient cycles belowground ............................. 3

1.1.3 Use of stable isotopes for tracing $C$ and $N$ in the plant- soil system ......................... 8

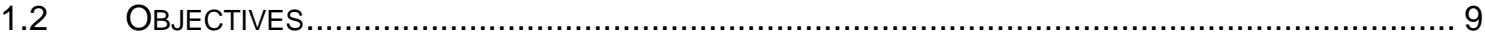

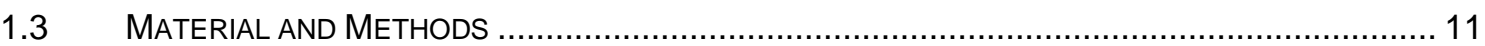

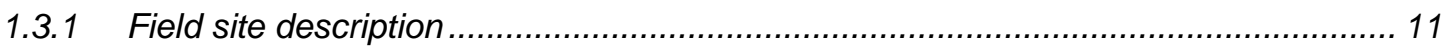

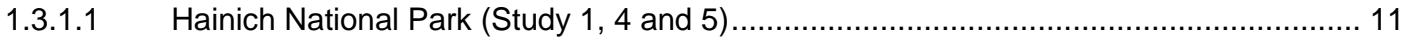

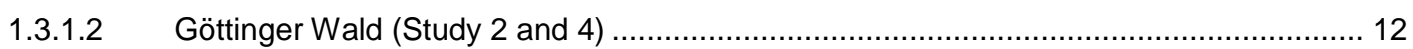

1.3.1.3 Short rotation coppice / Agroforest site Reiffenhausen (Study 6) ................................. 13

1.3.2 Experimental setup and realization of study 1, 4 and 5....................................... 14

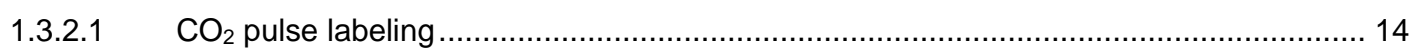

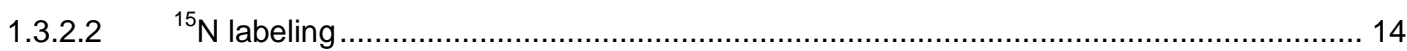

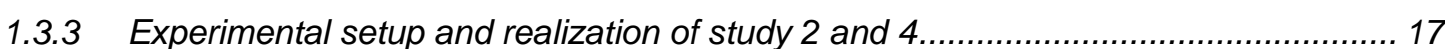

1.3.4 Experimental setup and realization of study 6 ...................................................... 19

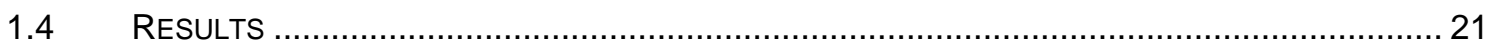

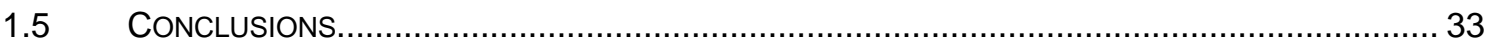

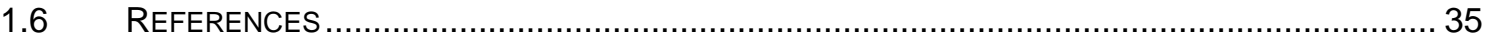

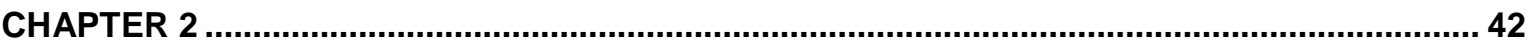

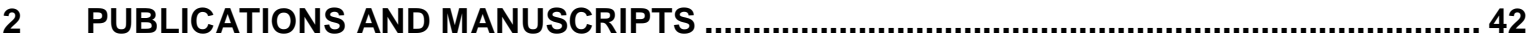

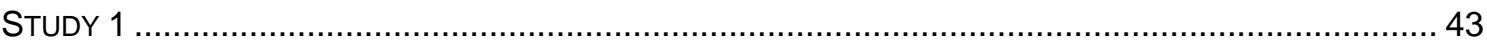

2.1 AlLOCATION AND DYNAMICS OF C AND N WITHIN PLANT-SOIL SYSTEM OF ASH AND BEECH..... 43

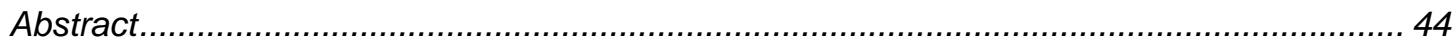

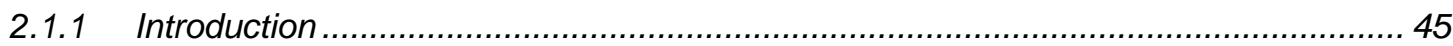




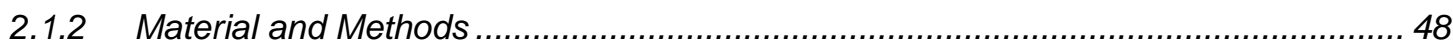

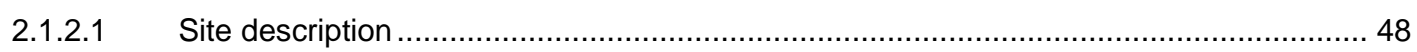

2.1.2.2 Experimental design and sampling setup .............................................................. 48

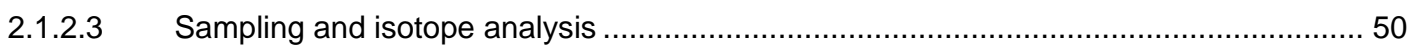

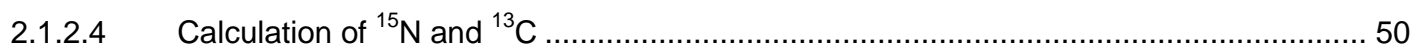

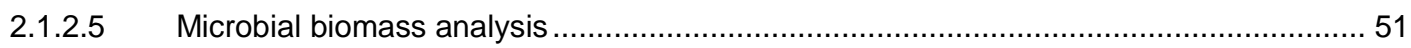

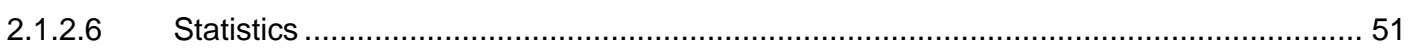

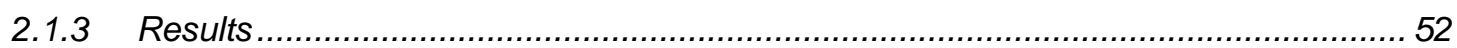

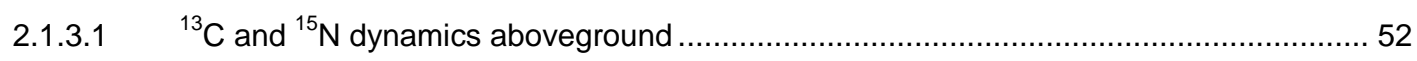

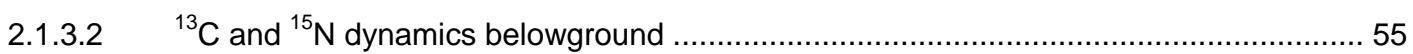

2.1.3.3 Spatial gradients of ${ }^{15} \mathrm{~N}$ and ${ }^{13} \mathrm{C}$ allocation around the trees .................................... 57

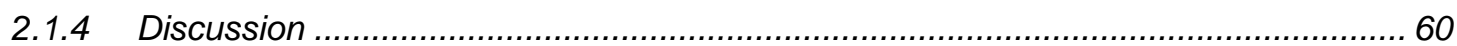

2.1.4.1 C allocation within plant-soil system depending on tree species .................................60 60

2.1.4.2 N allocation within plant-soil system depending on tree species ................................. 63

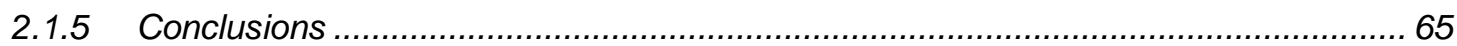

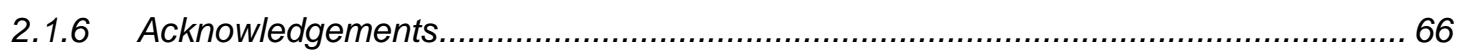

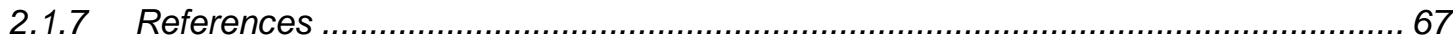

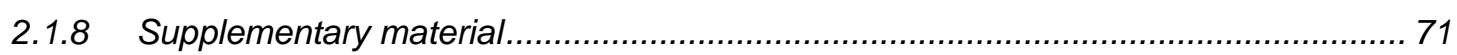

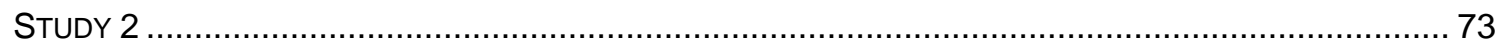

2.2 THE TREE SPECIES MATTERS: BELOWGROUND CARBON INPUT AND UTILIZATION IN THE MYCO-

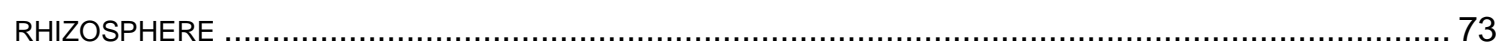

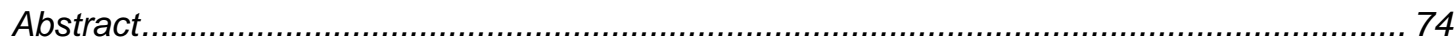

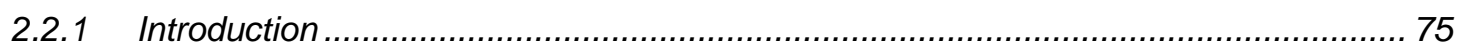

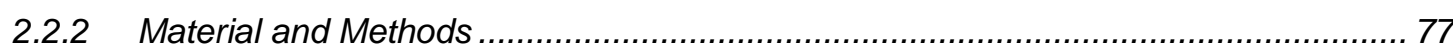

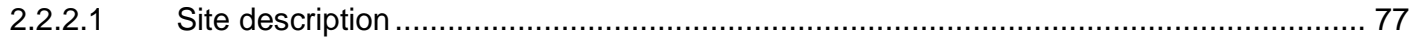

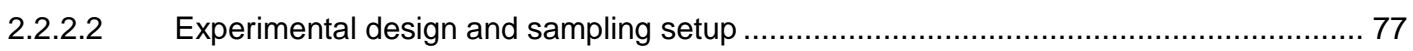

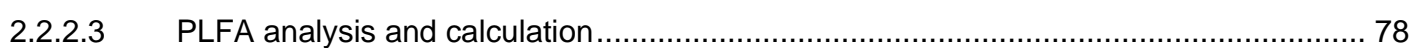

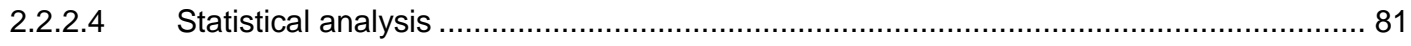

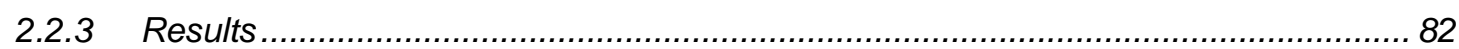

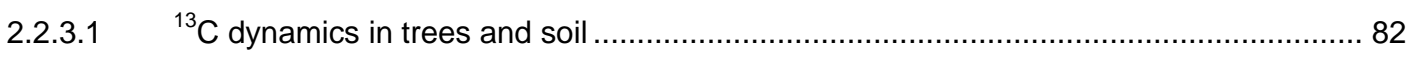

2.2.3.2 Abundance of microbial groups in ash and beech soil.......................................... 83

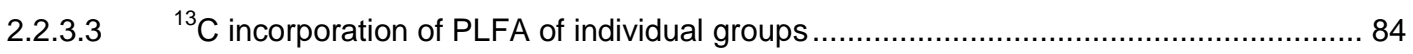

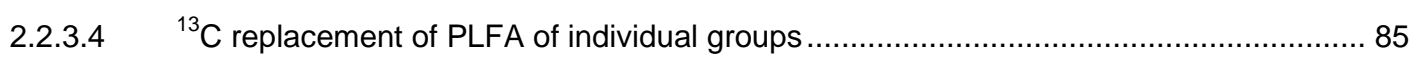

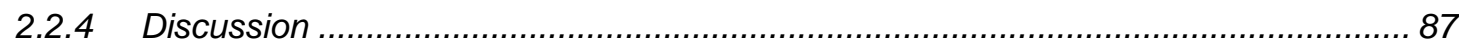

2.2.4.1 C allocation within the plant-soil system as affected by tree species.......................... 87

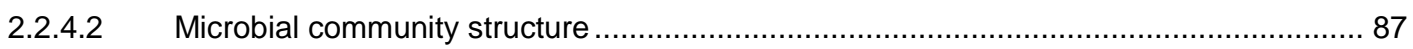

2.2.4.3 Incorporation and replacement of root $\mathrm{C}$ into the microbial community ......................... 88

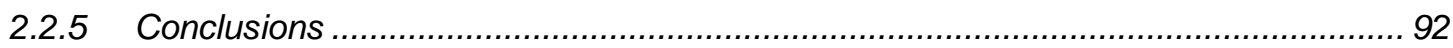

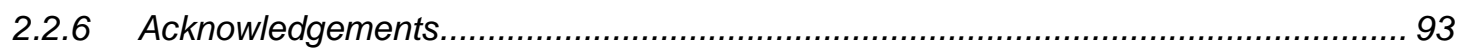

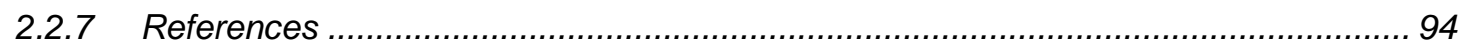

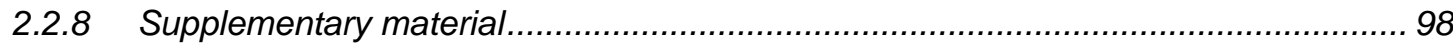

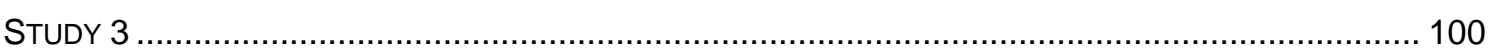

2.3 MECHANISMS OF PHOSPHATE ACQUISITION BY MYCORRHIZA ...................................... 100 


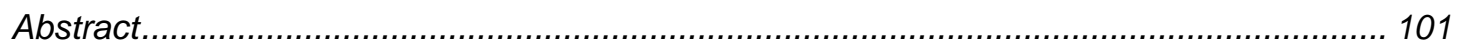

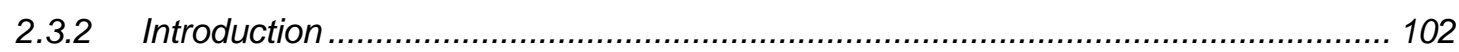

2.3.3 Phosphorus availability in soil................................................................. 107

2.3.4 Phosphorus uptake by fungus ............................................................ 110

2.3.4.1 Phosphorus uptake in Ectomycorrhizal Fungi...................................................... 110

2.3.4.2 Phosphorus uptake in Arbuscular Mycorrhizal Fungi............................................... 111

2.3.4.3 Phosphorus uptake in orchid mycorrhiza......................................................... 112

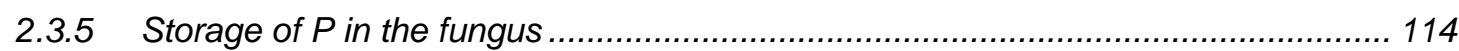

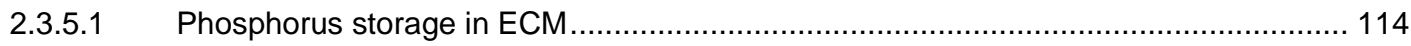

2.3.5.2 Phosphorus storage in AM ............................................................................. 115

2.3.6 Transport of $P$ in the fungus-plant interface ........................................... 117

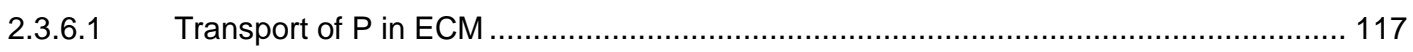

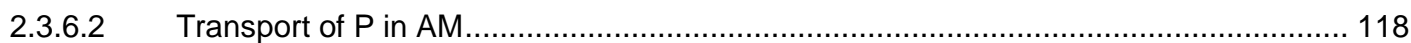

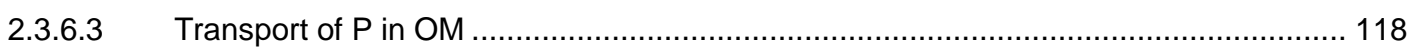

2.3.7 Phosphorus deficient ecosystems ............................................................. 121

2.3.8 Epiphytic orchids-a special case in P deficient survival .................................... 123

2.3.9 Conclusions .......................................................................................... 125

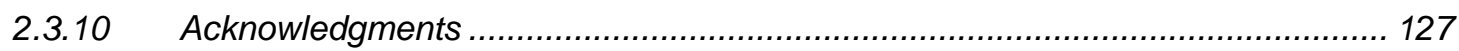

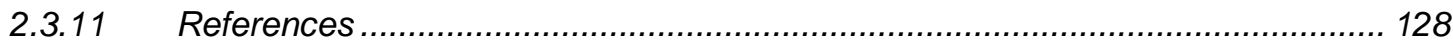

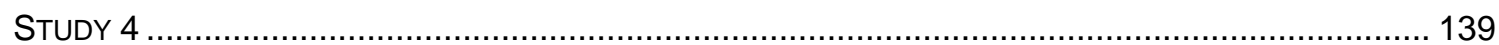

2.4 DIFFERENT RESPONSES OF ASH AND BEECH ON NITRATE VERSUS AMMONIUM LEAF LABELING 139

Abstract. 140

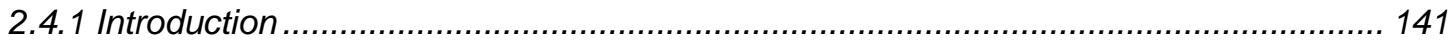

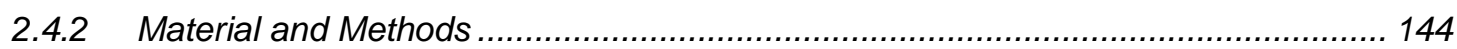

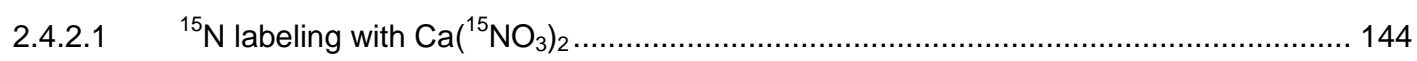

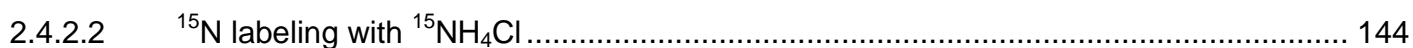

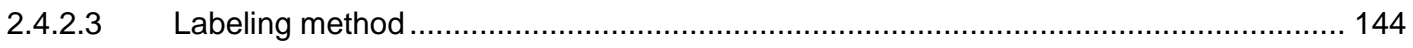

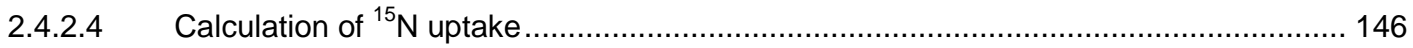

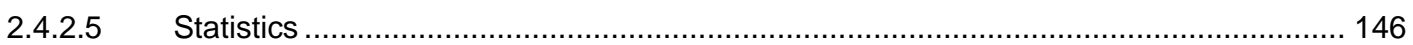

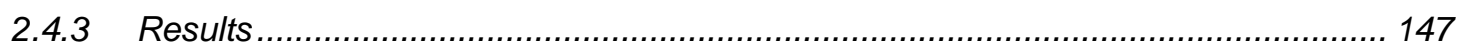

2.4.2.1 $\quad{ }^{15} \mathrm{~N}$ incorporation into plant tissues and soil.................................................... 147

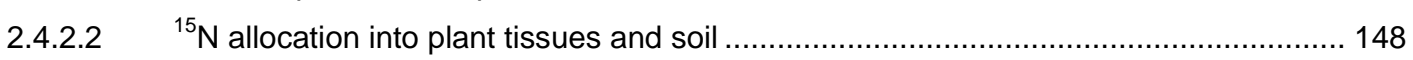

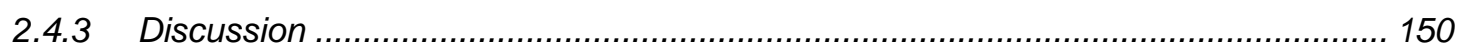

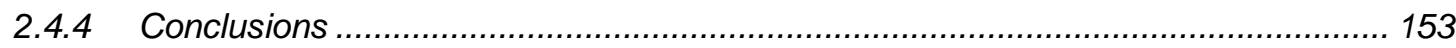

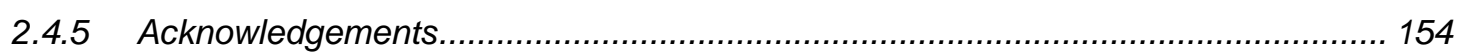

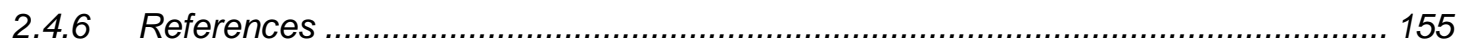

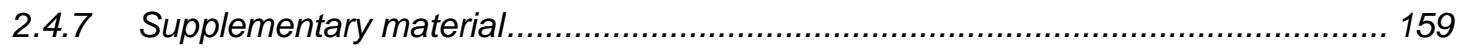

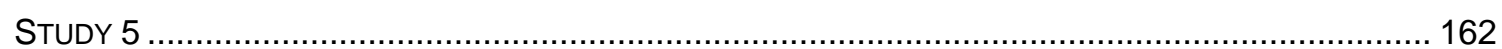

2.5 BEECH TREES FUEL SOIL ANIMAL FOOD WEBS VIA ROOT DERIVED NITROGEN.................. 162

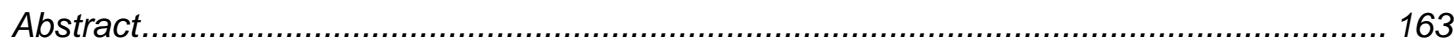

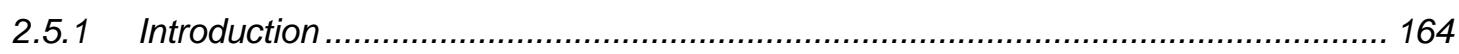

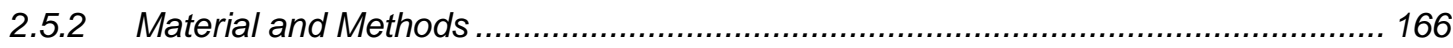




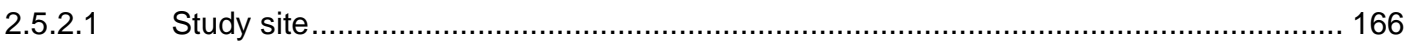

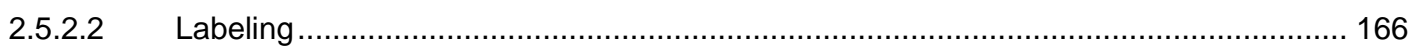

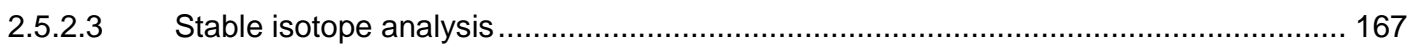

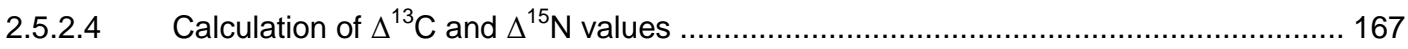

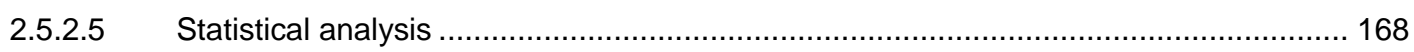

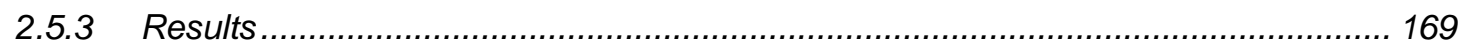

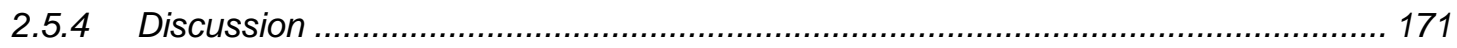

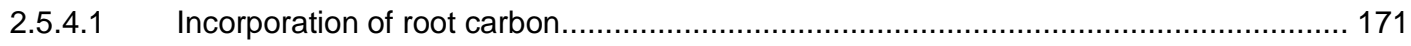

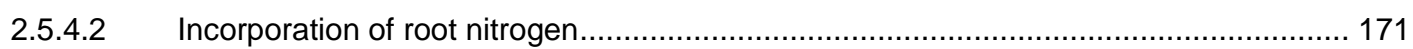

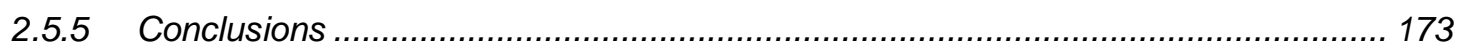

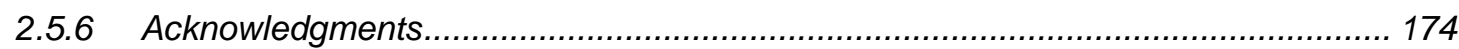

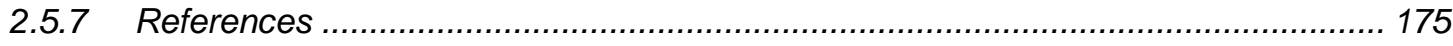

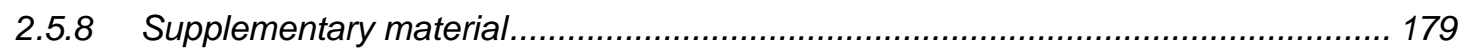

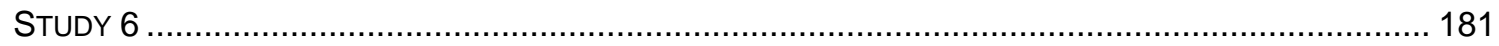

2.6 SPECIFIC N $N_{\text {MIN }}$ UPTAKE PATTERNS OF TWO WIDELY APPLIED POPLAR AND WILLOW CLONES FOR SHORT ROTATION COPPIESES - IMPLICATIONS FOR MANAGEMENT PRACTICES ............................. 181

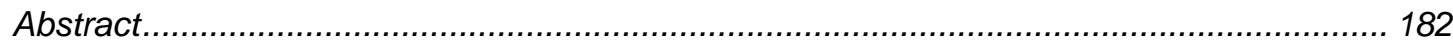

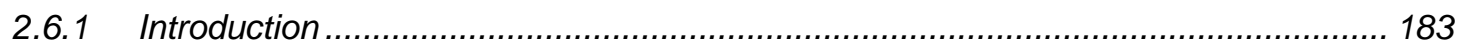

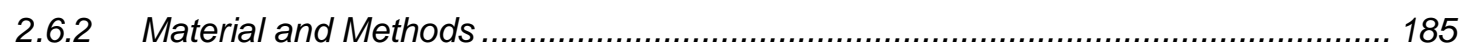

2.6.2.1 Soil characteristics and soil sampling setup ....................................................... 185

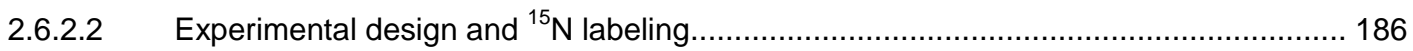

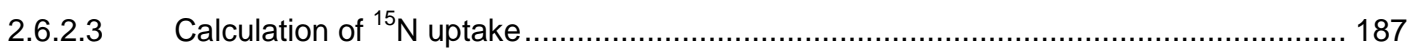

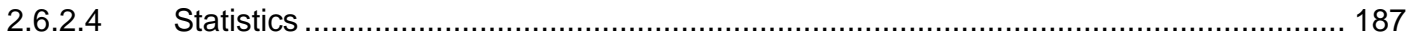

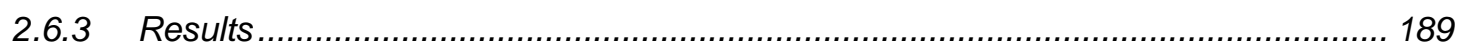

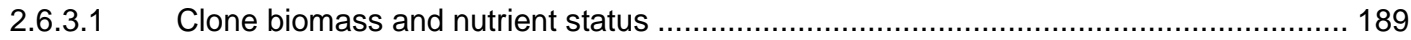

2.6.3.2 $\quad{ }^{15} \mathrm{~N}$ recovery into plant compartments ......................................................... 190

2.6.3.3 $\quad{ }^{15} \mathrm{~N}$ allocation into tree compartments................................................................ 191

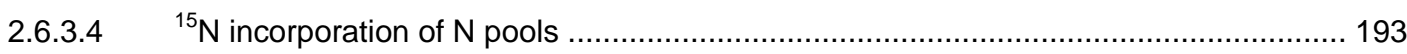

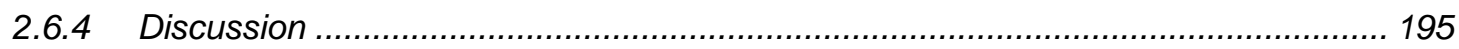

2.6.4.1 Species-specific uptake of ammonium and nitrate ............................................ 195

2.6.4.2 Species-specific N allocation and incorporation pattern .......................................... 196

2.6.4.3 Criteria for selection of poplar versus willow for SRCs …........................................ 197

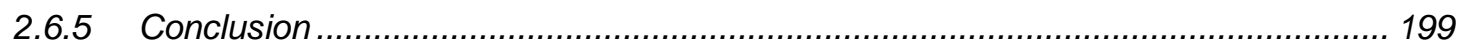

2.6.6 Acknowledgements........................................................................ 200

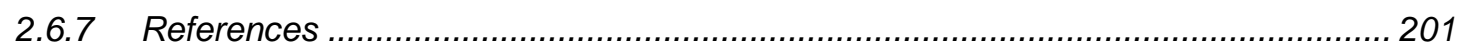

2.6.8 Supplementary material..................................................................... 205

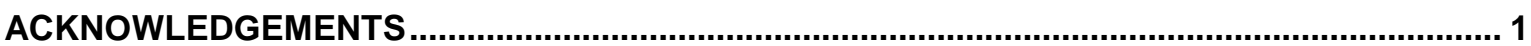

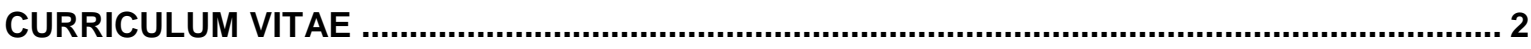

DECLARATION OF ORIGINALITY AND CERTIFICATE OF AUTHORSHIP ................................ 5 


\section{Summary}

Various studies suggest that the main mechanism of biodiversity effects on ecosystem function is niche complementarity, but it is challenging to assess complementarity among plant species understanding its key mechanisms. The essential idea of niche differentiation is that individual species with complementary niches in an ecosystem will use resources more effectively leading to a higher primary productivity than in the corresponding monocultures. Therefore, we focused on differences in carbon (C) and nitrogen $(\mathrm{N})$ allocation patterns above- and belowground between beech (Fagus sylvatica L.) and ash (Fraxinus excelsior L.) as one mechanism of niche differentiation in forests. The species-specific rhizodeposition and $\mathrm{N}$ nutrition, the linked microbial activity and the involved soil fauna play a crucial role on the $\mathrm{C}$ and $\mathrm{N}$ cycle in the tree-soil system. Interest on research regarding deciduous forests as an important sink for atmospheric carbon dioxide $\left(\mathrm{CO}_{2}\right)$ and tree species which are able to enhance that function has increased in the last decades. Currently, we have a much more profound understanding on the significance of litter of individual tree species on the $C$ and nutrient dynamics in deciduous forest, than that which exists on root-mediated effects. Root derived $\mathrm{C}$ and $\mathrm{N}$ enters the soil as exsudates, leakages or decaying root materials and stimulates microbial growth and activity in the rhizosphere and controls the turnover of $\mathrm{C}$ and $\mathrm{N}$ in the soil food web. However, there is a lack of comprehensive understanding how species identity affects the amount of plant-derived $\mathrm{C}$ and $\mathrm{N}$ and, consequently, the activity of the soil organisms in temperate mixed deciduous forests. For that reason this thesis aims to investigate the effect of beech and ash on the $\mathrm{C}$ and $\mathrm{N}$ cycle and its dynamics in the tree and the nutrient link to microbes, with special emphasize on mycorrhiza.

Stable isotope analysis has been increasingly used to investigate and trace $C$ and nutrient cycles and their structure, quantities and underlying mechanisms even in natural ecosystems in steady state. However, it has not been applied to quantitatively characterize species-specific in situ $\mathrm{C}$ and $\mathrm{N}$ dynamics in deciduous trees at the level of all major compartments above- and belowground. Therefore, I coordinated a pulse labeling experiment in the National Park Hainich were ${ }^{13} \mathrm{CO}_{2}$ and $\mathrm{Ca}\left({ }^{15} \mathrm{NO}_{3}\right)_{2}$ were applied on the canopy of beech and ash to focus on $\mathrm{C}$ and $\mathrm{N}$ allocation patterns from above- to belowground. The incorporation and allocation of $\mathrm{C}$ and $\mathrm{N}$ in the different tree compartments and the root-derived $\mathrm{C}$ and $\mathrm{N}$ in the soil food web were examined for 60 days. Beech assimilated twice as much of the applied ${ }^{13} \mathrm{CO}_{2}$ as ash $(20 \%$ versus $9 \%$, respectively) and transported the fixed $\mathrm{C}$ and $\mathrm{N}$ more rapidly than ash belowground. The 
incorporated ${ }^{15} \mathrm{~N}$ amounts (45\%) into leaves were similar in both tree species. However, ash preferentially accumulated ${ }^{15} \mathrm{~N}$ and ${ }^{13} \mathrm{C}$ in the roots and beech released more of this initially assimilated ${ }^{13} \mathrm{C}$ and ${ }^{15} \mathrm{~N}$ via rhizodeposition into the soil, which was also subsequently recovered in microbial biomass. Thus more root-derived $\mathrm{N}$ was incorporated into soil animals under beech in comparison to ash and therefore was the contribution of root $\mathrm{N}$ to soil animal nutrition tree species - specific. After all plant-derived $\mathrm{C}$ and $\mathrm{N}$ could be detected in mesofauna decomposer and revealed therefore not only a $\mathrm{C}$ transfers from fungi and microbial biomass to the next higher trophic levels and demonstrated therefore that species-specific root $\mathrm{N}$ deposition has an imprint on the soil animal food webs. Additionally, the tracer recovery in soil and microbial biomass was determined three dimensionally (vertically and horizontally) and revealed horizontally a homogenous distribution to a distance of $55 \mathrm{~cm}$ from stem but also a clear vertically species-specific effect. The ${ }^{13} \mathrm{C}$ and ${ }^{15} \mathrm{~N}$ allocation decreased with soil depth under beech up to $30 \mathrm{~cm}$ but ash allocated more ${ }^{13} \mathrm{C}$ in $10-20 \mathrm{~cm}$ soil. Those results reflect the differences in root morphology of beech and ash and demonstrate again the tree species effect on the $C$ and $\mathrm{N}$ cycle in the soil.

Alongside with the major field experiment a laboratory study was performed. This experiment addressed specifically the tree species effect on the associated microbial rhizosphere community, which were identified, and its $C$ uptake from tree quantified by following an isotopic labelling approach with ${ }^{13} \mathrm{CO}_{2}$ of $1 \mathrm{~m}$ high beeches and ashes. The ${ }^{13} \mathrm{C}$ incorporation into phospholipid fatty acids (PLFA) reflected that utilization of the rhizodeposits by individual microbial community members was strongly affected by the tree species although differences in the overall community structure were less pronounced under the investigated tree species. Saprotrophic and ectomycorrhizal fungi under beech and ash - but also arbuscular mycorrhizal fungi and Gram negative bacteria under ash - revealed the vast majority of the ${ }^{13} \mathrm{C}$ recovered in PLFA. $30 \%$ of the fungal PLFA C was replaced within 5 days by rhizodeposit-derived ${ }^{13} \mathrm{C}$ under beech and $10 \%$ under ash, whereas freely associated bacterial groups reached maximally $3 \%$ replacement of their membrane lipids by ${ }^{13} \mathrm{C}$. This suggests that the direct $\mathrm{C}$ allocation via mycorrhizal symbioses dominates 1 ) the $C$ allocation belowground in deciduous forests and 2) the $C$ nutrition of fungi and makes PLFA to a valuable tool to differentiate $C$ fluxes from trees into different types of mycorrhiza (ECM versus AMF). Despite the investigated differences of the tree species - specific C rhizodeposition, reviewing the role of mycorrhiza in various natural ecosystems and mycorrhization types revealed that presumably this high $\mathrm{C}$ allocation dynamics towards fungal partners is vastly driven by the $P$ cycle, i.e. an exchange of $C$ versus $P$. Consequently, the impact of mycorrhization on $P$ cycling is a topic of global relevance requiring much higher attention in future research. 
I compared two ${ }^{15} \mathrm{~N}$ leaf pulse labeling approaches to be able to trace ${ }^{15} \mathrm{~N}$ in belowground processes after rhizodeposition. Thus, suitability of these labeling approaches for the production of highly ${ }^{15} \mathrm{~N}$ enriched litter for subsequent decomposition studies could be evaluated. The leaf labeling with $\mathrm{Ca}\left({ }^{15} \mathrm{NO}_{3}\right)_{2}$ and ${ }^{15} \mathrm{NH}_{4} \mathrm{Cl}$ enabled both to focus on $\mathrm{N}$ allocation patterns from above- to belowground with the key purpose of understanding the linkages of the tree species and the soil $\mathrm{N}$ cycle in temperate mixed deciduous forests. ${ }^{15} \mathrm{NH}_{4} \mathrm{Cl}$ resulted in a higher incorporation and more homogenous distribution between the tree compartments in ash and beech and therefore, ${ }^{15} \mathrm{NH}_{4} \mathrm{Cl}$ labelling is more appropriate for allocation studies. Both ${ }^{15} \mathrm{~N}$ tracers enable long-term labeling in in situ field studies on $\mathrm{N}$ rhizodeposition and allocation in soils as they did not cause any damage of the leaves but the leaf labeling with $\mathrm{Ca}\left({ }^{15} \mathrm{NO}_{3}\right)_{2}$ might be the better choice to produce highly enriched ${ }^{15} \mathrm{~N}$ leaf litter in comparison to ${ }^{15} \mathrm{NH}_{4} \mathrm{Cl}$, because more ${ }^{15} \mathrm{~N}$ remains in the leaves for further long term in situ litter decomposition and turnover studies.

The species-specific plant-derived $\mathrm{C}$ allocation and maybe also $\mathrm{N}$ allocation are implying an increased microbial activity. This may presumably lead to higher $\mathrm{N}$ plant availability belowground and might therefore be one of the explanations for the positive effect of plant diversity on forest stand productivity due to niche partitioning. Such species - niche partitioning between trees might not only increase productivity of natural ecosystem but might similarly enhance productivity in tree-based land use systems. Therefore, the $\mathrm{N}$ cycle of a short rotation coppice was studied in an in-situ labeling approach with ${ }^{15} \mathrm{NH}_{4} \mathrm{NO}_{3}$ and $\mathrm{NH}_{4}{ }^{15} \mathrm{NO}_{3}$ on fast growing willow and poplar tree cuttings. The experiment aimed to investigate $\mathrm{N}$ uptake and allocation within the tree soil system from belowground with the focus on biomass, especially wood production in the initial growth period. Poplar produces more biomass in the initial growth period and incorporated twice as much ${ }^{15} \mathrm{NO}_{3}{ }^{-}$from the $\mathrm{N}$ soil pool in comparison to the willow and might be therefore the better choice whenever nitrate surplus at agricultural sites should rapidly be bound in biomass. Poplar incorporated also three times more ${ }^{15} \mathrm{NO}_{3}{ }^{-}$than ${ }^{15} \mathrm{NH}_{4}{ }^{+}$, whereas willow incorporated exactly the same amount of ${ }^{15} \mathrm{~N}$ from both tracers. Those results broaden the general notion that deciduous trees prefer nitrate in contrast to ammonium and is evidence for species - specific uptake of $\mathrm{NH}_{4}^{+}$or $\mathrm{NO}_{3}^{-}$in deciduous trees. However, further experiments which close the link between plant-derived $\mathrm{N}$ deposition as driver for decomposer activity and $\mathrm{N}$ uptake from the soil food web to raise wood productivity are required to understand the key mechanisms controlling the $\mathrm{N}$ cycle in such agroforest systems.

In summary, this thesis deepens our understanding of the effect of tree species on the $C$ and $\mathrm{N}$ cycles in soil. It demonstrates that rhizodeposition, fueling very specifically the activity of distinct microbial and fungal groups is one of the main mechanisms underlying 
the observed tree-specific effects on $\mathrm{C}$ and $\mathrm{N}$ dynamics. This calls for further application of the here presented and evaluated labeling methods for other natural forests or agroforest ecosystems. 


\section{Zusammenfassung}

Diverse Studien deuten darauf hin, daß das wichtigste Instrumentarium für die Wirkung der Artenvielfalt auf die Funktionen eines Ökosystems die Nischen-Komplementarität ist, aber auch daß es sehr schwierig ist diese wechselseitige Ergänzung und ihre wesentlichen Mechanismen zwischen den Pflanzenarten zu verstehen. Der Grundgedanke der Nischendifferenzierung ist, daß individuelle Arten mit sich ergänzenden Nischen die in einem Ökosystem vorhandenen Ressourcen besser nutzen, um eine höhere primäre Produktivität zu erreichen als in Monokulturen. Darum haben wir uns auf die Unterschiede in der ober- und unterirdischen Verteilung von Kohlenstoff (C) und Stickstoff (N) zwischen Buche und Esche als ein Mechanismus der Nischendifferenzierung in Wäldern konzentriert. Die artenspezifische Rhizodeposition und der Stickstoffernährungszustand und die damit verbundene mikrobielle Aktivität spielen genauso wie die beteiligte Bodenfauna eine erhebliche Rolle im C und N Kreislauf des Baum-Boden Systems. Das Interesse der Forschungsvorhaben in den letzten Jahrzehnten bezog sich auf Laubwälder als wichtige Speicher für atmosphärisches $\mathrm{CO}_{2}$ und Baumarten die in der Lage sind diese Funktion zu verbessern. Derzeit haben wir umfassendere Kenntnisse über die Bedeutung von Streu von einzelnen Baumarten auf die Kohlenstoff- und Nährstoffdynamik im Laubwald als über wurzelbezogene Effekte. Wurzelbürtiger $\mathrm{C}$ und $\mathrm{N}$ werden in den Boden als Exsudate, Verlust durch Auslaufen oder zerfallendes Wurzelmaterial abgegeben. Hier regen sie einerseits mikrobielles Wachstum und Aktivität in der Rhizosphäre an und kontrollieren andererseits den C und N Umsatz in der Nahrungskette im Boden. Dennoch fehlt uns das Verständnis wie sich spezielle Arten auf die Menge des pflanzenbürtigen $\mathrm{C}$ und $\mathrm{N}$ auswirken und somit die Aktivität von Bodenorganismen in Laubwäldern der gemäßigten Zone beeinflussen. Aus diesem Grund erforscht diese Dissertation die Effekte von Buche und Esche auf den C und N Kreislauf und seine Dynamik im Baum und weiterhin den Zusammenhang zwischen Nährstoffen und Mikroben, mit Fokus auf Mycorrhiza und Bodenfauna.

Die stabile Isotopenanalyse wurde vermehrt eingesetzt um C und N Nährstoffkreisläufe und ihre Struktur, Mengen und die zugrunde liegenden Mechanismen zu untersuchen, und sogar um Prozesse in natürlichen Ökosystemen im Fließgleichgewicht verfolgen zu können. Trotzdem ist diese Methode bisher noch nicht angewandt worden um die artspezifische $\mathrm{C}$ und N Dynamik in Laubwäldern in allen wesentlichen Kompartimenten ober- und unterirdisch zu beschreiben. Deshalb koordinierte ich ein Pulse Markierungsexperiment im National Park Hainich, bei dem ${ }^{13} \mathrm{CO}_{2}$ und $\mathrm{Ca}\left({ }^{15} \mathrm{NO}_{3}\right)_{2}$ auf das 
Laubdach von Buche und Esche aufgebracht wurde, um die $\mathrm{C}$ und $\mathrm{N}$ Verteilung von oben bis in den Boden genauer untersuchen zu können. Die Aufnahme und Verteilung von $\mathrm{C}$ und $\mathrm{N}$ in den verschieden Baumkompartimenten und der wurzelbürtige $\mathrm{C}$ und $\mathrm{N}$ in der Nahrungskette im Boden wurden 60 Tage lang untersucht. Buche assimilierte zweimal so viel ${ }^{13} \mathrm{CO}_{2}$ wie Esche (20 bzw. 9\%) und transportierte das aufgenommene $\mathrm{C}$ und $\mathrm{N}$ schneller in den Boden als Esche. Die von den Blättern aufgenommene Menge ${ }^{15} \mathrm{~N}(45 \%)$ war ähnlich in beiden Baumarten. Esche jedoch akkumuliert bevorzugt ${ }^{15} \mathrm{~N}$ und ${ }^{13} \mathrm{C}$ in der Wurzel während Buche gibt mehr von dem anfangs assimilierten ${ }^{13} \mathrm{C}$ und aufgenommenen ${ }^{15} \mathrm{~N}$ via Rhizodeposition an den Boden abgibt, welcher dann anschließend in der mikrobiellen Biomasse wieder gefunden werden konnte. Deshalb wurde auch mehr wurzelbürtiger $\mathrm{N}$ in die Bodenfauna unter Buche eingebaut als unter Esche, somit ist der Eintrag von Wurzelstickstoff in die Bodenfauna baumartspezifisch. Aufgrund der Tatsache, daß pflanzenbürtiger $\mathrm{C}$ und $\mathrm{N}$ in den Mesofauna Zersetzern wiedergefunden werden konnte, ist nicht nur bewiesen worden, daß ein $C$ Transport von den Pilzen und der mikrobiellen Biomasse zu der nächst höheren trophischen Ebene stattfindet, sondern auch, daß die artspezifische Wurzel N Deposition einen Einfluss auf das Nahrungsnetz im Boden hat. Zusätzlich wurde die Tracer Wiederfindung im Boden und in der mikrobiellen Biomasse dreidimensional (vertikal und horizontal) bestimmt; diese zeigte horizontal eine homogene Verteilung bis zu $55 \mathrm{~cm}$ vom Stamm aber vertikal eine artspezifische Verteilung. Die Verteilung $\operatorname{von}{ }^{13} \mathrm{C}$ und ${ }^{15} \mathrm{~N}$ war mit zunehmender Bodentiefe $(0-30 \mathrm{~cm})$ unter Buche abnehmend, doch Esche gab mehr ${ }^{13} \mathrm{C}$ in die Tiefe von $10-20 \mathrm{~cm}$ in den Boden ab. Diese Ergebnisse reflektieren die Unterschiede in der Wurzelmorphologie von Buche und Esche und zeigten nochmals den Baumarteneffekt auf den $\mathrm{C}$ und $\mathrm{N}$ Kreislauf im Boden.

Neben dem hauptsächlichen Feldversuch wurde ein Laborversuch durchgeführt. Dieses Experiment adressierte besonders den Baumarteneffekt auf die dazugehörigen mikrobiellen Gruppen, welche mit der ${ }^{13} \mathrm{CO}_{2}$ Isotopenmarkierungsmethode an $1 \mathrm{~m}$ hohen Buchen und Eschen identifiziert wurden. Die ${ }^{13} \mathrm{C}$ Aufnahme in die Phospholipid Fettsäuen (PLFA) reflektierte, daß die Verwendung der Rhizodeposite von einzelnen mikrobiellen Gruppen stark von der Baumart beeinflusst wurde, obwohl die Struktur der mikrobiellen Gemeinschaft sich zwischen den untersuchten Baumarten nicht unterschied. Saprotrophe- und Ektomycorrhiza - Pilze von Buche und Esche - aber auch Arbuskuläre Mycorrhiza Pilze und gramnegative Bakterien unter der Esche - zeigten den Hauptteil des in den PLFA wieder gefundenen ${ }^{13} \mathrm{C}$. Von der pilzlichen PLFA C wurden innerhalb von fünf Tagen $30 \%$ durch das ${ }^{13} \mathrm{C}$ aus der Rhizodeposition der Buche ersetzt und $10 \%$ aus der Rhizodeposition der Esche, freie assoziierte Bakterien hingegen tauschten nur max. $3 \%$ ihrer Membranfette aus. Das deutet darauf hin, dass die direkte Verteilung von $\mathrm{C}$ via 
Mycorrhiza-Symbiose sowohl die unterirdische Verteilung des $C$ in Laubwäldern als auch die C Versorgung von Pilzen dominiert. Weiterhin hat sich die PLFA als eine geeignete Methode erwiesen, um Unterschiede im Kohlenstoffkreislauf von den Bäumen in die verschiedenen Mycorrhizaarten feststellen zu können. Die festgestellten Unterschiede in der ${ }^{13} \mathrm{C}$ Aufnahme und Umsetzung von der ganzen Myco-Rhizosphäre beweisen auch, dass der Kohlenstoffkreislauf im Boden erheblich von der artspezifischen Rhizodeposition und den Verbindungen der Wurzel mit anderen Organismen abhängt. Beim Rezensieren der Rolle von Mycorrhiza in verschieden natürlichen Ökosystemen und der Mycorrhizaarten kam zum Vorschein, dass vermutlich die hohe $\mathrm{C}$ Verteilung zu den Pilzpartnern hauptsächlich durch den Phosphorkreislauf gesteuert wird, z.B. als Austausch von C gegen P (Phosphor). Demnach ist der Einfluss der Mycorrhizierung auf den Phosphorkreislauf ein Thema, welches weltweite Relevanz hat und nach mehr Aufmerksamkeit in der zukünftigen Forschung verlangt.

Ich habe zwei ${ }^{15} \mathrm{~N}$ Pulsmarkierungsexperimente am Blatt durchgeführt um ${ }^{15} \mathrm{~N}$ in den unterirdischen Prozessen nach der Rhizodeposition verfolgen zu können. Dadurch konnte man diese Markierungsmethoden für die Produktion von hoch angereicherter Streu für weitere Zersetzungsstudien evaluieren. ${ }^{15} \mathrm{NH}_{4} \mathrm{Cl}$ hatte eine höhere Aufnahme und eine homogenere Verteilung zwischen den Baum Kompartimenten in Buche und Esche zur Folge und deswegen ist sie geeigneter für Allokations-Studien. Beide ${ }^{15} \mathrm{~N}$ Tracer erlauben in situ Langzeit-Markierungsexperimente der N Rhizodeposition und Allokation im Boden, da sie keinen Schaden an den Blättern hinterlassen. Dennoch ist die Markierung der Blätter mit $\mathrm{Ca}\left({ }^{15} \mathrm{NO}_{3}\right)_{2}$ im Vergleich $\mathrm{zu}{ }^{15} \mathrm{NH}_{4} \mathrm{Cl}$ die bessere Wahl, um hoch ${ }^{15} \mathrm{~N}$ angereichertes Blattstreu zu produzieren, da mehr des aufgenommenen ${ }^{15} \mathrm{~N}$ in den Blättern verbleibt für langzeitige Streu-Zersetzungs- und Umsatzstudien. Die artspezifische pflanzenbürtige C Allokation und vielleicht auch N Allokation impliziert einen Anstieg der mikrobiellen Aktivität. Das kann vermutlich zu einer höheren unterirdischen $\mathrm{N}$ Verfügbarkeit für Pflanzen führen und eine Erklärung für den positiven Effekt der Planzendiversität auf die Produktivität des Waldbestandes aufgrund von Nischen Partitionierung sein. Diese Arten - Nischen Partitionierung zwischen Bäumen könnte nicht nur die Produktivität in natürlichen Ökosystemen erhöhen, sondern auch die Produktivität von auf Holz basierenden Landnutzungssystemen. Deshalb wurde der Stickstoffkreislauf von einer Kurzumtriebsplantage mit einem Markierungsexperiment mit ${ }^{15} \mathrm{NH}_{4} \mathrm{NO}_{3}$ und $\mathrm{NH}_{4}{ }^{15} \mathrm{NO}_{3}$ an Weiden- und Pappelstecklingen untersucht. Das Experiment untersuchte die $\mathrm{N}$ Aufnahme und Allokation im Baum - Boden System von unten, mit Fokus auf die Biomasse und insbesondere auf die Holzproduktion in der anfänglichen Wachstumsphase. Die Weide zeigte keine Präferenz zwischen $\mathrm{NH}_{4}{ }^{+}$und $\mathrm{NO}_{3}{ }^{-}$, aber es konnte mehr $\mathrm{NH}_{4}{ }^{+}$als bei der Pappel in den Baumkompartimenten gefunden werden. Die 
Pappel hingegen produzierte mehr Biomasse in der anfänglichen Wachstumsphase, dennoch ist die Weide möglicherweise die bessere Wahl wenn Nitratüberschuss auf Agrarflächen schnell in Biomasse umgewandelt werden soll. Weitere Experimente, die eine Verknüpfung zwischen pflanzenbürtigem $N$ Eintrag als treibende Kraft für die Zersetzungsaktivität und die Stickstoffaufnahme vom Bodennahrungsnetz und der wachsenden Nachfrage nach Holz untersuchen, sind erforderlich, um die Hauptmechanismen in der Regulation des Stickstoffhaushaltes zu verstehen.

Zusammenfassend vertieft diese Dissertation unser Verständnis über Auswirkungen einzelner Arten auf den C und N Kreislauf im Boden. Sie zeigt, dass die Rhizodeposition, die einem baumartspezifischen Einfluss auf den $\mathrm{C}$ und $\mathrm{N}$ Kreislauf unterliegt, im Besonderen die Aktivität bestimmter mikrobieller und pilzlicher Gruppen verstärkt. Die untersuchten Markierungsmethoden bedürfen weiterer Anwendung in anderen Waldökosystemen und Landnutzungssystemen wie z.B. dem Agroforest. 


\section{List of Figures}

Figure 1.2-1: Overview of the studies within this thesis; Partitioning of photosynthetically fixed ${ }^{13} \mathrm{C}$ and assimilated ${ }^{15} \mathrm{~N}$ between plant and soil pools. The colors of the arrows and symbols show which fluxes and pools are quantified in the different Studies. The partitioning of ${ }^{13} \mathrm{C}$ and ${ }^{15} \mathrm{~N}$ was determined between leaf, root-, and microbial biomass, bulk soil and soil meso- and macrofauna to determine the incorporation of assimilated $C$ and $N$ following pulse labeling into the shown pools. 10

Figure 1.3-1: General conditions in the National Park Hainich; Leaf cover (A); Multiple aged trees stand (B); Stagnic Luvisol up to $30 \mathrm{~cm}$ depth (C) 12

Figure 1.3-2: General conditions Göttinger Wald; Multiple aged trees stand (A); Redzina (picture from beech forest Teutoburger Wald (Begonia, 2010)

Figure 1.3-3: General set up in the short rotation coppice / agroforest site Reiffenhausen (modified Hartmann et al. 2014). 13

Figure 1.3-4: Chambers that were used for simultaneous in situ ${ }^{13} \mathrm{CO}_{2}$ pulse labeling of 20 replicates per tree species $(A)$. Ventilation system inside the chamber $(B)$; split tube for soil sampling with three replicates per tree (C), $7 \mathrm{~cm}$ soil cores taken subsequently from the soil surface down to $30 \mathrm{~cm}$ depth $(D)$.

Figure 1.3-5: Setup used for ${ }^{15} \mathrm{~N}$ labeling with $\mathrm{Ca}\left({ }^{15} \mathrm{NO}_{3}\right)_{2}$ and ${ }^{15} \mathrm{NH}_{4} \mathrm{Cl}(\mathrm{A})$, labeling chamber for ${ }^{13} \mathrm{CO}_{2}$ pulse labeling of 20 replicates per tree species (B).; split tube for soil sampling $(C)$

Figure 1.3-6: Setup that was used for ${ }^{15} \mathrm{~N}$ labeling of willow and poplar cuttings with ${ }^{15} \mathrm{NH}_{4} \mathrm{NO}_{3}, \mathrm{NH}_{4}{ }^{15} \mathrm{NO}_{3}$ and reference treatment with $\mathrm{NH}_{4} \mathrm{NO}_{3}$

Figure 1.4-1: Summary of main results (all numbers show the incorporation in \% of the applied tracer 5 days after the labeling for $C$ values and 8 days for $N$ values; $C$ values are always displayed in black, $N$ values in red) 21

Table 1.4-7: Literature knowledge of basic research in italic type and novel research in regular type 
Figure 2.1-1: Upper panels: Total ${ }^{13} \mathrm{C}$ incorporation on day 1 in above- (left) and belowground (right) $C$ pools; Lower panel: Total ${ }^{15} \mathrm{~N}$ allocation of the maximal incorporated $\mathrm{Ca}\left(\mathrm{NO}_{3}\right)_{2}$ on day 13 for beech and day 8 for ash in above- (left) and belowground (right) $N$ pools; in 0-30 cm depth and at a distance of $15 \mathrm{~cm}$ radius from the tree, beech (black symbols) and ash (red symbols). Error bars show SEM. * shows significant $(p<0.05)$ differences of the different compartments between ash and beech.

Figure 2.1-2: ${ }^{13} \mathrm{C}$ allocation (in \% of the initially assimilated ${ }^{13} \mathrm{CO}_{2}$ at day one) in (A) leaves (diamonds) and stem (squares), (B) roots (triangle) and soil (circles), $0-30 \mathrm{~cm}$ depth at a distance of $15 \mathrm{~cm}$ from the tree. Relative ${ }^{15} \mathrm{~N}$ allocation of the maximal incorporated $\mathrm{Ca}\left(\mathrm{NO}_{3}\right)_{2}$ (day 13 for beech and day 8 for ash) in (C) leaves and stem $(D)$ roots and soil at $15 \mathrm{~cm}$ distance from tree at $0-30 \mathrm{~cm}$ depth in beech (black symbols) and ash (red symbols); Error bars show SEM; * shows significant $(p<0.05)$ differences of leaves and roots between beech and ash for individual sampling dates. \# shows significant $(p<0.05)$ differences of stem and soil between beech and ash for individual sampling dates.

Figure 2.1-3: Relative ${ }^{13} \mathrm{C}$ allocation (\% of the initially assimilated ${ }^{13} \mathrm{CO}_{2}$ at day one) in (A) soil at 0-10 cm depth (circle), $10-20 \mathrm{~cm}$ depth (triangles), 20-30 cm depth (diamonds) and (B) microbial biomass depending on depth and time at $15 \mathrm{~cm}$ distance from the tree and in beech (black symbols) and ash (red symbols). Relative ${ }^{15} \mathrm{~N}$ allocation of the maximal incorporated $\mathrm{Ca}\left(\mathrm{NO}_{3}\right)_{2}$ (day 13 for beech and day 8 for ash) in (C) soil and (D) microbial biomass depending on depth and time. Error bars show SEM; * shows significant $(p<0.05)$ differences between beech and ash at one depth of $0-10 \mathrm{~cm}$, \# at a depth of 10-20 cm; small letters show differences between depths in one tree species: (a) shows significant $(p<0.05)$ differences between beech soil at a depth of 0 $10 \mathrm{~cm}$ to both other depths for individual sampling dates (b) shows differences between ash soil at a depth of $10-20 \mathrm{~cm}$ to both other depths for individual sampling dates.

Figure 2.1-4: Relative ${ }^{13} \mathrm{C}$ allocation (in \% of the initially assimilated ${ }^{13} \mathrm{CO}_{2}$ ) with linear fits in soil at 0-10 cm depth (circle/solid line), 10-20 cm depth (triangles/long dash line), $20-30 \mathrm{~cm}$ depth (diamonds/dotted lines) and distance from the tree at day 5 after labeling and in beech (black symbols/lines) and ash (red symbols/lines). For parameters of the linear regressions see Table 2.1-3. 
Relative $N$ allocation of the maximal incorporated ${ }^{15} \mathrm{~N}$ (day 13 for beech and day 8 for ash) with linear fits in soil depending on depth and distance from the tree. Error bars show SEM. 58

Figure 2.1-5: Relative ${ }^{13} \mathrm{C}$ allocation (in \% of the initially assimilated 13CO2) with linear fits in microbial biomass at $0-10 \mathrm{~cm}$ depth (circle/solid line), $10-20 \mathrm{~cm}$ depth (triangles/long dash line), $20-30 \mathrm{~cm}$ depth (diamonds/dotted lines) depending on depth and distance from the tree at day 5 after labeling and in beech (black symbols/lines) and ash (red symbols/lines). For parameters of the linear regressions see Table 2.1-3. Relative $N$ allocation of the maximal incorporated ${ }^{15} \mathrm{~N}$ (day 13 for beech and day 8 for ash) with linear fits in microbial biomass depending on depth and distance from the tree. Error bars show SEM. 59

Figure 2.2-1: Total ${ }^{13} \mathrm{C}$ incorporation (\% $\pm S E M, N=10$ ) of the applied ${ }^{13} \mathrm{CO}_{2}$ in leaves, stem, roots and soil (0-10 cm depth) on day 5 and 20 after labeling of beech (black circles) and ash (grey triangles). * significant $(p<0.05)$ differences in ${ }^{13} \mathrm{C}$ incorporation in compartments between ash and beech on day $5,+$ significant differences on day 20 after labeling. Lower case letters show significant $(p<0.05)$ differences between day 5 and day 20 after labeling in beech (b) and ash (a).

Figure 2.2-2: Amount of fatty acids ( $\mu \mathrm{g} \mathrm{g}^{-1}$ soil) in microbial groups in ash (grey triangle) and beech soil (black circle). Error bars show SEM $(N=10)$; * significant ( $p<$ 0.05) differences between the tree species 5 days after the start of the ${ }^{13} \mathrm{C}$ labeling. 84

Figure 2.2-3: ${ }^{13} \mathrm{C}$ incorporation into PLFAs (\% of ${ }^{13} \mathrm{C}$ input) of applied $\mathrm{CO}_{2}$ in microbial groups in ash (grey triangle) and beech soil (black circle). Error bars show SEM $(N=10)$; + significant $(p<0.05)$ differences between beech and ash at day 5 and * at day 20 after labeling. Lower case letters indicate significant ( $p<$ 0.05) differences between day 5 and day 20 after labeling in beech (b) and $\operatorname{ash}(a)$.

Figure 2.2-4: ${ }^{13} \mathrm{C}$ replacement (\% of PLFA-C) of microbial PLFAs in ash (grey triangle) and beech soil (black circle). Error bars show SEM $(N=10)$; symbols indicate significant differences to all other microbial groups in beech ( $\left.{ }^{*}\right)$ and ash (+) 20 days after labeling and in beech (\#) 5 days after ${ }^{13} \mathrm{C}$ labeling $(p<0.05)$. Lower case letters $(a, b, c)$ indicate significant differences between microbial groups in ash 5 days after ${ }^{13} \mathrm{C}$ labeling $(p<0.05)$. .86 
Figure 2.3-1: Nutrient uptake modes and life cycle differences in orchid mycorrhizal associations. a) The nutritional modes of orchids from complete autotrophs to mycoheterotrophs. There is an increasing reliance on fungal derived nutrients such as $P, C, N$ and micronutrients (brown triangle) towards nonphotosynthetic mycoheterotrophs, conversely there is an increasing reliance on photosynthetically derived sources of $C$ and fungal derived sources of $P, N$ and micronutrients towards the autotrophic orchids (green triangle). b) The reliance of orchids on their fungal partners can change from mycoheterotrophic seedling to degrees of autotrophy in the adult stage......104

Figure 2.3-2: Phosphorus forms in soil and its pathways to the plant uptake 108

Figure 2.3-3: Phosphorus retention map with selected biodiversity hotspots in $P$ deficient regions (Myers et al., 2000; Reich, 2015) 121

Figure 2.4-1: ${ }^{15} \mathrm{~N}$ incorporation of applied $\mathrm{Ca}\left({ }^{15} \mathrm{NO}_{3}\right)_{2}$ (black symbols; $\mathrm{N}=4$ ) and ${ }^{15} \mathrm{NH}_{4} \mathrm{Cl}$ (grey symbols; $N=10$ ) eight days after the start of the labeling for beech (left) and ash (right) in leaves (diamonds), stem (squares), roots (triangle) and soil (circles). Error bars show SEM. Small letters show significant $(p<0.05)$ differences of ${ }^{15} \mathrm{~N}$ in leaves between the tree species and between the ${ }^{15} \mathrm{~N}$ forms.

Figure 2.4-2: Relative ${ }^{15} \mathrm{~N}$ allocation of applied $\mathrm{Ca}\left({ }^{15} \mathrm{NO}_{3}\right)_{2}$ (black symbols; $\mathrm{N}=4$ ) and ${ }^{15} \mathrm{NH}_{4} \mathrm{Cl}$ (grey symbols; $N=10$ ) eight days after the start of the labeling for beech (left) and ash (right) in leaves (diamonds), stem (squares), roots (triangle) and soil (circles). Error bars show SEM.

Figure 2.5-1: Enrichment in $\Delta^{13} \mathrm{C}$ and $\Delta^{15} \mathrm{~N}$ in soil animals (average of all species analyzed) under beech (dark grey) and ash (light grey) 20 days after labeling with ${ }^{13} \mathrm{CO}_{2}$ and $\mathrm{Ca}^{15} \mathrm{NO}_{3}$. Means and standard deviation are back-transformed values of log-transformed data

Figure 2.5-2: Enrichment in $\Delta^{15} \mathrm{~N}$ in soil animal species 20 days after labeling with ${ }^{13} \mathrm{CO}_{2}$ and $\mathrm{Ca}^{15} \mathrm{NO}_{3}$. Means and standard deviation are back-transformed values of log-transformed data.

Figure 2.6-1: Dry matter yield of poplar cv. Max 1 and willow cv. Tordis after 56 days of growth ( $N=12$ ); leaves (white), twigs (grey), stems (dark grey) and roots (black). Stars shows significant differences $(p<0.05)$ of dry matter content between the tree species. Error bars show SEM. 190 
Figure 2.6-2: ${ }^{15} \mathrm{~N}$ recovery in \% of applied $\mathrm{NH}_{4}{ }^{15} \mathrm{NO}_{3}$ (black symbols; $\mathrm{N}=4$ ) and ${ }^{15} \mathrm{NH}_{4} \mathrm{NO}_{3}$ (grey symbols; $N=4$ ) seven days after the start of the labeling for poplar (left) and willow (right) in leaves (diamonds), twigs (squares), stem (triangle), roots (circles) and the all measured compartments of the tree (star). Error bars show SEM. Plus (+) shows significant differences $(p<0.05)$ of ${ }^{15} \mathrm{~N}$ in that plant compartment between the tree species. Lower case letters show significant differences $(p<0.05)$ of ${ }^{15} \mathrm{~N}$ in that plant compartment between the $N_{\text {min }}{ }^{-}$ species in poplar (a) and willow (b). 191

Figure 2.6-3: ${ }^{15} \mathrm{~N}$ allocation in \% of assimilated ${ }^{15} \mathrm{NO}_{3}$ (black symbols; $\mathrm{N}=4$ ) and ${ }^{15} \mathrm{NH}_{4} \mathrm{NO}_{3}$ (grey symbols; $N=4$ ) seven days after the start of the labeling for poplar (left) and willow (right) in leaves (diamonds), twigs (squares), stem (triangle), roots (circles). Error bars show SEM. Plus (+) shows significant differences $(p<0.05)$ of ${ }^{15} \mathrm{~N}$ in that plant compartment between the tree species. Lower case letters show significant differences $(p<0.05)$ of ${ }^{15} \mathrm{~N}$ in that plant compartment between the $N_{\text {min }}$-species in poplar (a) and willow (b). 192

Figure 2.6-4: ${ }^{15} \mathrm{~N}$ incorporation in \% of $\mathrm{N}$ pool, ${ }^{15} \mathrm{NO}_{3}$ (black symbols; $\mathrm{N}=4$ ) and ${ }^{15} \mathrm{NH}_{4} \mathrm{NO}_{3}$ (grey symbols; $N=4$ ) seven days after the start of the labeling for poplar (left) and willow (right) in leaves (diamonds), twigs (squares), stem (triangle), roots (circles). Error bars show SEM. Plus (+) shows significant differences ( $p<$ 0.05) of ${ }^{15} \mathrm{~N}$ in that plant compartment between the tree species. Lower case letters show significant differences $(p<0.05)$ of ${ }^{15} \mathrm{~N}$ in that plant compartment between the $N_{\text {min }}$-species in poplar (a) and willow (b). 193 


\section{List of Tables}

Table 1.3-1: General soil properties of the investigated area. Data were taken from Guckland et al. (2009)

Table 1.3-2: Summary of the material and methods used in study 1,4 and 5 ................16

Table 1.3-3: Summary of the material and methods used in study 2 and 4 18

Table 1.3-4: Summary of the material and methods usd in study 6 20

Table 1.4-1: Overview of the objectives and main results of the study 1. 22

Table 1.4-2: Overview of the objectives and main results of the study 2. 23

Table 1.4-3: Overview of the objectives and main results of the study 3. 24

Table 1.4-4: Overview of the objectives and main results of the study 4. 25

Table 1.4-5: Overview of the objectives and main results of the study 5 26

Table 1.4-6: Overview of the objectives and main results of the study 6 . 27

Table 2.1-1: Mean above biomass. 48

Table 2.1-2: Mean temperature and humidity, during the labeling period for ${ }^{13} \mathrm{C}$ from 8 am to $7 \mathrm{pm}$. 72

Table 2.1-3: Parameter list for the Linear Regression of ${ }^{13} \mathrm{C}$ and ${ }^{15} \mathrm{~N}$ incorporation over time

Table 2.2-1: Identified microbial groups and their specific fatty acid amounts (mean \pm SEM) in soil of beech and ash seedlings. 79

Table 2.2-2: Mean plant biomass ( \pm SEM), soil mass and specific leaf area of beech and ash

Table 2.2-3: Fatty acids in the external standard. 99

Table 2.3-1: Summary of types of mycorrhizal associations. 103

Table 2.3-2: Phosphorus uptake in AM, ECM and OM. 112 
Table 2.3-3: Phosphorus budget expressed as percentage of whole plant $P$ allocated to various organs of mycorrhizal plants. The molybdite blue (Murphy and Riley, 1962) or adapted methods were used to estimate the percentage of $P$ in the organs of mycorrhizal plants.

Table 2.4-1: Mean aboveground biomass 160

Table 2.4-2: Factorial ANOVA table of results for the ${ }^{15} \mathrm{~N}$ incorporation of the applied tracer and their variance between tree species, between ${ }^{15} \mathrm{~N}$ forms and between tree species and ${ }^{15} \mathrm{~N}$ forms effects of ${ }^{15} \mathrm{~N}$ incorporation of different plant compartments / soil. 160

Table 2.4-3: Factorial ANOVA results of the relative ${ }^{15} \mathrm{~N}$ allocation of the assimilated tracer between tree species, between ${ }^{15} \mathrm{~N}$ forms and between tree species and ${ }^{15} \mathrm{~N}$ form effects of relative ${ }^{15} \mathrm{~N}$ allocation to plant compartments and soil. 161

Table 2.5-1: $\Delta^{13} \mathrm{C}$ and $\Delta^{15} \mathrm{~N}$ values of species of Acari: Oribatida and Myriapoda: Chilopoda of beech and ash trees 20 days after labelling. 180

Table 2.6-1: Chemical soil properties at the beginning of the experiment $(N=3) \pm S E M .186$

Table 2.6-2: Mean ( \pm SEM) nutrient content of poplar leaves and willow leaves $(N=12) \pm$ SEM, optimal nutrient supply according to Röhricht and Ruscher [25]. 189

Table 2.6-3: T-test for independent samples of results for the ${ }^{15} \mathrm{~N}$ recovery of the applied tracer and their differences between tree species and between the $N_{\text {min }}{ }^{-}$ species in poplar cv. Max 1 and willow cv. Tordis of different plant compartments. 206

Table 2.6-4: T-test for independent samples of results for the ${ }^{15} \mathrm{~N}$ allocation of assimilated tracer and their differences between tree species and between the $N_{\text {min }}$ species in poplar cv. Max 1 and willow cv. Tordis of different plant compartments. 207

Table 2.6-5: T-test for independent samples of results for the ${ }^{15} \mathrm{~N}$ incorporation of the $\mathrm{N}$ pool and their differences between tree species and between the $N_{\min }$-species in poplar cv. Max 1 and willow cv. Tordis of different plant compartments...208 


\section{Abbreviations}

${ }^{13} \mathrm{C}$ Stable Carbon Isotope, mass of $13 \mathrm{~g} \mathrm{~mol}^{-1}$ ${ }^{15} \mathrm{~N}$ Stable Nitrogen Isotope, mass of $15 \mathrm{~g} \mathrm{~mol}^{-1}$

Ac. Actinomycetes

AMF. .Arbuscular Mycorrhiza ANOVA .Analysis of Variance

C Carbon

$\mathrm{C}_{\text {org }}$ Organic Carbon

DOC Dissolved Organic Carbon

ECM Ectomycorrhiza ERM Ericoid Mycorrhiza FAME Fatty acid methyl esters

$\mathrm{G}+$ Gram positive bacteria

GGram negative bacteria HSD Honestly Significant Difference IS Internal Standard $\mathrm{N}$ Nitrogen

OM Orchid Mycorrhiza $P$. Phosphorus

$\mathrm{Pi}$ Inorganic Phosphate

PLFA Phospholipid Fatty Acid

$\operatorname{Pr}$ Protozoa

SEM. Standard Error of Mean

SF Saprothrophic fungi SOC. Soil Organic Carbon SOM Soil Organic Matter $\mathrm{SRC}$ Short rotation coppices 
Chapter 1

\section{Extended Summary}




\section{$1.1 \quad$ Introduction}

\subsubsection{The link between biodiversity and ecosystem functioning}

Global sustainability and human economic wealth depend on ecosystem products and services that result from biodiversity and associated ecological functions such as primary productivity, soil formation, and especially nutrient cycling (Wu, 2013; Wu et al., 2015). Previous research has made major progress in describing the relationship between species diversity and ecosystem processes and their underlying mechanisms to identify functionally important species (Loreau et al., 2001). However, even if most researchers have focused on the relationship of biodiversity and ecosystem function researchers have conducted most of their experiments to date in the grasslands and made only a few attempts in forests (Hector et al., 1999; Paquette and Messier, 2011; Spehn et al., 2005; Tilman et al., 1996). More research focused on the soil biochemistry of conifer forests, rather than deciduous forests, because procedures regarding afforestation and increased timber production and therefore planting of large areas of productive coniferous tree species in monocultures were imposed (Augusto et al., 2002; Berger et al., 2009a; Berger et al., 2009b; Mareschal et al., 2010).

Ecological experiments and observations confirmed that ecosystem properties depend greatly on biodiversity in terms of the functional characteristics of organisms presents and their distribution and abundance over space and time in the ecosystem (Hooper et al., 2005). Dynamics and amounts of $\mathrm{C}$ and $\mathrm{N}$ and other nutrient cycles are determined by the composition of aboveground diversity and belowground communities interacting with each other (Berger et al., 2009a; Berger et al., 2009b). Interestingly, the strongest effects of species richness on productivity were discovered in grasslands with a relatively low number of species (Hector et al., 1999; Tilman et al., 1996). Northern European forests, where beech is the most common deciduous tree, are also characterized by a low plant biodiversity (Thünen-Institut, 2012). European beech grows robustly under diverse environmental conditions and hydrological and soil chemical factors including soil moisture and nitrogen availability, due to its interspecific competitiveness and is preferentially used for the conversion of coniferous monocultures into mixed stands (Leuschner et al., 2006). However, the sensitivity of European beech to environmental constraints depends on neighborhood identity and competitive complementarity (Metz et al., 2016). 
We expect that in such low-diversity ecosystems individual species and species composition might have an intensive impact on $\mathrm{C}$ and nutrient cycles above- and belowground and such effects can be controlled via litter and / or rhizodeposits. The following sections and the experiments of this thesis therefore provide new insights about plant-derived $\mathrm{C}$ and $\mathrm{N}$ input in the tree soil system and how they are influenced by tree species. 


\subsubsection{The species effects on the $C$ and nutrient cycles belowground}

Various studies suggest that the main mechanism of biodiversity effects on ecosystem function is niche complementarity, but it is challenging to clearly quantify complementarity among plant species and to explain its key mechanisms (Wu et al., 2015). The essential idea of niche differentiation or facilitation is that different species with complementary niches in an ecosystem will use resources more effectively and this leads to higher primary productivity than in the corresponding monocultures (Cadotte, 2013; Loreau and Hector, 2001). Therefore, we conducted four studies to link $C$ and $N$ in the forest canopy with $\mathrm{C}$ and $\mathrm{N}$ in the soil and focused on differences in $\mathrm{C}$ and $\mathrm{N}$ allocation patterns aboveand belowground between ash and beech as one mechanism of niche differentiation in forests (Studies 1, 2, 4, 5). Study 3 focused on mycorrhiza as link between $P$ and $C$ for further studies and the sixth study regarded a SRC as intermediate systems bringing the advantages of forests nutrient dynamics at least partially into agroecosystems and focused on primary productivity.

One of the key ecosystem functions of forests, as a sink for atmospheric $\mathrm{CO}_{2}$, is mediated by the tree species which assimilate the $\mathrm{CO}_{2}$ and allocate it towards the soils as storage reservoir - and thus control the stored SOM (Goodale et al., 2002; Oostra et al., 2006; Vesterdal et al., 2008). The path from C rhizodeposition of plants continues via microbial uptake and mineralization or physical stabilization by occlusion in aggregates and micropores. Sequestration of $\mathrm{C}$ can also result in interactions with surfaces and metal ions or biochemical stabilization due to the molecular structure of the organic matter. The plant species influence not only the storage of $C$ but also ecosystem processes such as plant biomass production, decomposition and especially nutrient cycling. (Gamfeldt et al., 2008; Hooper et al., 2005; Wu et al., 2015). Hence the sink function of the forest soil may be increased by the appropriate choice of tree species - a fact of increasing importance in light of global climate change. Therefore, we conducted an in situ pulse labeling experiment with ${ }^{13} \mathrm{CO}_{2}$ on beech and ash to investigate the species-specific flux of treederived $\mathrm{C}$ into the soil to be able to quantify the allocation of assimilates (Study 1 and 2).

Most biodiversity experiments to date have focused on the species effects on aboveground processes and very little is known about belowground processes, soil microorganisms, and the soil fauna and their link to tree species in mixed-species forests (Scherer-Lorenzen et al., 2005). There is a knowledge gap regarding the amount, composition and dynamic of tree species-specific rhizodeposits and their effects the $\mathrm{C}$ and 
$\mathrm{N}$ cycle in the soil food web. Rhizodeposits include a variety of compounds, such as sugars, amino and aromatic acids, proteins and enzymes to attract beneficial organisms in the rhizosphere. Approximately $30 \%$ of root-derived C is metabolized as low molecular substances by bacterial communities (Badri et al., 2009; Holtkamp et al., 2011). Soil microbes occur as active, viable, living, dormant, passive, dying, or dead organisms but only active microbes process the available substrate of the rhizodeposition and rely therefore on the species-specific amount and availability of plant derived organic carbon $\left(\mathrm{C}_{\text {org }}\right)$ (Blagodatskaya and Kuzyakov, 2013; Johnsen et al., 2001; Lennon and Jones, 2011). Beech roots for example are associated with ECM while ash roots are associated with AMF (Meinen et al., 2009) and therefore it can be expected that not only the rhizodeposition is species - specific but also a divers microbial community and especially fungi will impact amounts and dynamics in the $\mathrm{C}$ and $\mathrm{N}$ cycle belowground. But very little is known about root derived $\mathrm{C}$ and $\mathrm{N}$ allocations in the microbial community in situ under trees. In the present study, we were able to trace by ${ }^{13} \mathrm{C}$ incorporation into phospholipid fatty acids (PLFA) of the identified microbial groups, the microbial uptake and utilization of the rhizodeposits of beech and ash which gave us the possibility to study the effects of tree species diversity on microbial community structure (Study 2 ).

The results of study two demonstrated the vital role of the microbial community and especially the mycorrhizal association on the $C$ cycle in forest ecosystem. To broaden our understanding on the role of mycorrhiza in forest and other ecosystems, we reviewed the functions of the major mycorrhiza types on the nutritional cycles in the soil in diverse ecosystems (Study 3). Besides our own data from study 2, many previous reviews showed that in deciduous forests, large quantities of photoassimilates become allocated to mycorrhiza and rhizosphere microbes (Högberg et al., 2008)(cite here more), and mycorrhizal fungi function as pathways for $\mathrm{C}$ and nutrient exchange with and between plants (Klein et al., 2016; Perry et al., 1992). Actually most terrestrial plants are associated with mycorrhizal fungi and spend a significant part of their $C$ resources for trading with fungi for nutrients, especially phosphorus (Allen, 1991). Mycorrhiza improves plant fitness using biochemical and biophysical strategies to increase the effectiveness and absorption surface to mobilize $P$ and $N$ from the soil (Johnson et al., 2010). The identity and composition of the microbial community and especially fungal species may influence plant community structure and ecosystem productivity (van der Heijden et al., 1998). The present study focused on the species-specific rhizodeposits of beech and ash into the PLFAs of different microbial groups to be able to estimate the fungal activity of the associated mycorrhiza (Study 2). As a result, mycorrhizal associations fuel the autotrophic system by maintaining nutrient supply and are therefore crucial constituents in ecosystem resilience especially facing the challenges of global change (Hynson et al., 2012; 
Wallander et al., 2011). Consequently, an understanding of fungi in future management practices in order to maintain diverse ecosystems and their overall role for all kind of ecosystems, including deciduous forests, would benefit understanding of these crucial processes (Study 3).

Besides direct allocation of $\mathrm{C}$ to mycorrhizal fungi, exchanging $\mathrm{C}$ for nutrients, plant rhizodeposits induce higher microbial activity for many microbial groups in the rhizosphere and consequently may lead to a higher SOM decomposition and $\mathrm{N}$ release from SOM - a process termed rhizosphere priming effect (Kuzyakov, 2002). Many recent studies suggest that the question, whether rhizodeposition causes a positive or negative rhizopriming - i.e. promotes SOM decomposition or stabilization - is driven by the microorganism's need for N (Bengtson et al., 2012; Cheng et al., 2014; Fontaine and Barot, 2005; Fontaine et al., 2003). Consequently, the $\mathrm{N}$ cycle is likely have a controlling function over SOM and other nutrient cycles and should receive particular consideration in natural ecosystems. This includes processes controlled microbially, i.e. from belowground like mineralization, nitrification, plant assimilation and microbial immobilization but add processes that add or remove $\mathrm{N}$ such as deposition, $\mathrm{N}$ fertilization, biological fixation, denitrification and leaching, which are regulated from aboveground (Hart et al., 1994). The types of tree species affect the amount of microbial biomass, and consequently $\mathrm{N}$ immobilization and mineralization, the composition and activity of the soil fauna and the storage of $\mathrm{N}$ by the soil, e.g. through the input of $\mathrm{N}$ with their leaf litter (Finzi et al., 1998; Saetre et al., 1999; Vesterdal et al., 2008). About 50 to $60 \%$ of plant-assimilated $\mathrm{N}$ in deciduous forests is annually returned via litterfall to the soil (Khanna et al., 2009) but little is known about the effect of species-specific $\mathrm{N}$ rhizodeposition in temperate mixed deciduous forests on the spatial and temporal variability of soil $\mathrm{N}$ cycling (Augusto et al., 2002; Neirynck et al., 2000; Rothe and Binkley, 2001). Such studies exist for mature coniferous forests and for pure deciduous stands (Davidson et al., 1992; Hart et al., 1994) but are absent for mixed deciduous forests especially focusing on the role of individual tree species. To investigate the detailed effect of varying tree species on the soil $\mathrm{N}$ cycle in temperate mixed deciduous forests we performed an aboveground leaf-labeling experiment with $\mathrm{Ca}\left({ }^{15} \mathrm{NO}_{3}\right)_{2}$ and ${ }^{15} \mathrm{NH}_{4} \mathrm{Cl}$ to be able to focus on $\mathrm{N}$ allocation patterns from aboveground to belowground and to gain detailed information on the $\mathrm{N}$ cycle in soil-plant systems. As the outcome of such studies strongly depends on the chosen labeling approach and comparison between various widely used $\mathrm{N}$ tracers are absent, we also compared two leaf-labeling methods to be able to assess 1 ) the production of highly ${ }^{15} \mathrm{~N}$ enriched litter for subsequent decomposition studies and 2) the ability to use the respective tracer for assessing the $\mathrm{N}$ dynamics at the soil-plant interface (Study 4). 
The species-specific rhizodeposition and therefore $\mathrm{C}$ and $\mathrm{N}$ amounts and availability in the soil influences the activity and relative abundance of fungi and bacteria that form the basis of soil food web. However, the interaction between plant roots, root exudates, and microorganisms can only be understood in relation to soil faunal activity because the microbial biomass, activity and composition is also impacted by a the micro-, meso- and macro-fauna (Bonkowski et al., 2000). Protozoal micro-fauna are considered to be effective bacterial predators because of their high turnover rates and high numbers in rhizosphere soil. They are known to increase plant growth because plant roots are able to compete with microorganisms for $\mathrm{N}$ released due to protozoan grazing (Zwart et al., 1994). Protozoan grazing also changes the microbial community structure and therefore overall ecosystem properties (Krome et al., 2009; Rosenberg et al., 2009). Collembola and oribatid mites are known to feed selectively on certain ectomycorrhizal fungi (Hiol et al., 1994; Kanters et al., 2015; Remen et al., 2010) but the infection rate by arbuscular mycorrhiza and therefore plant growth was found to decrease with increasing collembolan density (Harris and Boerner, 1990). Therefore, is likely that the fungal community is subject to a selective feeding pressure by fungivorous microarthropods which may influence plant growth via grazing and it is likely that plants benefit to a different degree from the mutualistic relationship with protozoa. Therefore, we investigated in a ${ }^{13} \mathrm{C}$ and ${ }^{15} \mathrm{~N}$ field labeling approaches the in situ flux of plant-derived $\mathrm{C}$ and $\mathrm{N}$ into the soil animal food web under trees with different mycorrhizal associations, beech (ECM) and ash (AMF). This aims to explore the role of root-derived $\mathrm{C}$ and $\mathrm{N}$ for the nutrition of soil animal species (Study 5)

Whereas natural ecosystems such as deciduous forests are characterized by relatively closed nutrient, especially N cycles (Lukac and Godbold, 2011; Schulze, 2000) agricultural systems frequently suffer from a high annual loss of $\mathrm{N}$ (van Kessel et al., 2009). Short rotation coppices (SRC) and agroforest systems can be regarded as intermediate systems bringing the advantages of forests nutrient dynamics at least partially into agroecosystems. However, the degree to which advantageous nutrient cycling can be gained by agroforestry has barely been investigated up to now - and surely strongly dependent on the forest management regime. Classical systems consist mainly of poplar and willow trees and aim for the production of high amounts of woody biomass in a relatively short period of time with lower fertilizer requirements, higher $\mathrm{N}$-use efficiency, and lower $\mathrm{N}$ emission than conventional annual crops (Schmidt-Walter and Lamersdorf, 2012). Although perennial energy crops like SRC with fast-growing trees have played only a minor role in bioenergy production, the total cultivated area for SRC increases constantly and promising alternative environmental-friendly way of biomass production. The widespread occurrence of $\mathrm{N}$ limitation to net primary production in terrestrial 
ecosystems is something of a puzzle (Vitousek and Howarth, 1991). Recent research investigated $\mathrm{N}$ nutrition via ammonium and nitrate for many herbaceous plants and tree species like beech, spruce, ash and oak, but very little is known about the in situ $\mathrm{N}$ uptake related tree growth in willow and poplar (Buchmann et al., 1995; Nadelhoffer et al., 2004; Schulz et al., 2011). Furthermore, neither studies from forest nor from agroecosystems can be transferred to SRC as the tree - soil system is quite complex due to the differences to forests in leaf area index, transpiration rate, root distribution, root depth and effects on microclimate in the soil. Consequently, we investigated the $\mathrm{N}$ cycles in particular $\mathrm{N}$ nutrition and the avoidance of $\mathrm{N}$ limitation in SRC in the initial growth period focusing on the link between SRC dynamics and the tree biomass production of willow and poplar in the last study of this dissertation (Study 6). 


\subsubsection{Use of stable isotopes for tracing $\mathrm{C}$ and $\mathrm{N}$ in the plant- soil system}

Stable isotopes are ideally suited to solve biogeochemical problems in an ecosystem because stable isotope data can contribute to both source-sink (translocation) and process information (transformation) (Peterson and Fry, 1987). The stable isotopes ${ }^{12} \mathrm{C}$, ${ }^{13} \mathrm{C},{ }^{14} \mathrm{~N}$ and ${ }^{15} \mathrm{~N}$ used in the current work consist of the same number of protons and electrons, but differ in the number of neutrons and have therefore different atomic weights which can be measured with great precision with isotope ratio mass spectrometers. Naturally, the ${ }^{12} \mathrm{C}(98.892 \%)$ and ${ }^{14} \mathrm{~N}(99.635 \%)$ isotopes dominate strongly in their distribution over ${ }^{13} \mathrm{C}(1.108 \%)$ and ${ }^{15} \mathrm{~N}$ (0.365) (Sulzman, 2007) therefore the heavy isotopes can be used as a tracer. So if a $\mathrm{C}$ or $\mathrm{N}$ pool is significantly enriched or depleted relative to another pool it possible to track the flows from one pool to another pool and consequently enable stable isotopes a very precise quantification of fluxes between pools (Dawson et al., 2002).

Stable carbon isotope labeling at the canopy scale is a very potent tool for tracing $\mathrm{C}$ allocation in forest ecosystems (Korner et al., 2005). Increasing concentrations of atmospheric $\mathrm{CO}_{2}$ encouraged studies on soil $\mathrm{C}$ cycling and especially $\mathrm{C}$ sequestration, storage, and stabilization (von Lützow et al., 2006). The nature of photosynthesis dictates the way of application in labeling experiments. $\mathrm{N}$ in contrast reaches the plant-soil system from aboveground via litter input, anthropogenic deposition and rainfall or from belowground via fixation or oxidation of $\mathrm{N}_{2}$ (Schulze 2000). This opens up many different labeling methods and due to the diverse $\mathrm{N}$ forms, a large number of tracer chemicals which can be used to increase our understanding of $\mathrm{N}$ cycle in ecosystems (for methodology see study 4). 


\subsection{Objectives}

This thesis targets to assess the effects of tree species diversity on allocation and dynamics of $\mathrm{C}$ and $\mathrm{N}$ within plant-soil system and nutrient utilization in the mycorhizosphere of ash and beech.

In summary the objectives of the present work were to (Figure 1.2-1):

1) identify species-specifics in $\mathrm{N}$ and $\mathrm{C}$ allocation within the tree and to quantify the $\mathrm{C}$ and $\mathrm{N}$ input into the different $\mathrm{C}$ and $\mathrm{N}$ compartments of beech and ash (Study 1).

2) quantify the $\mathrm{C}$ and $\mathrm{N}$ allocation into the soil along a depth gradient down to $30 \mathrm{~cm}$ (Study 1).

3) determine the microbial utilization of root-derived $\mathrm{C}$ and $\mathrm{N}$ along the depth gradient down to $30 \mathrm{~cm}$ (Study 1).

4) determine the spatial gradients of ${ }^{15} \mathrm{~N}$ and ${ }^{13} \mathrm{C}$ allocation by rhizodeposition with increasing distance from beech and ash trees in the bulk soil and microbial biomass (Study 1).

5) assess the tree-specific rhizosphere effect on microbial biomass (Study 1) and microbial community composition (Study 2)

6) assess the utilization of beech and ash rhizodeposits by individual microbial groups with special focus on $\mathrm{C}$ allocation to the different mycorrhiza types (ECM versus AMF) of the two tree species (Study 2)

7) generalize the knowledge on ecosystem functions of ECM and AMF with focus on $\mathrm{P}$ acquisition, uptake and storage and the linkage to the $\mathrm{C}$ cycle i.e. the exchange of $C$ for $P$ and vice versa (Study 3 ).

8) elucidate a suitability ${ }^{15} \mathrm{~N}$ leaf-labeling method to investigate $\mathrm{N}$ allocation patterns above- and belowground, i.e. the suitability of various approaches to assess belowground $\mathrm{N}$ allocation to allow the production of highly ${ }^{15} \mathrm{~N}$ enriched litter for subsequent decomposition studies (Study 4).

9) quantify the uptake of tree-derived $\mathrm{N}$ and $\mathrm{C}$ by the soil meso- and macrofauna to assess their impact on forest $\mathrm{C}$ and $\mathrm{N}$ cycle (Study 5). 
10) determine woody biomass growth in agroforestry systems with poplar and willow and link their biomass dynamics to the key nutrient $\mathrm{N}$, i.e. the distribution patterns of nitrate and ammonium within different plant compartments (Study 6)

11) identify not only species- but hybrid-specific effects on SRC' $N$ cycle via the identification of clone-specific inorganic $\mathrm{N}$ uptake preferences (Study 6)

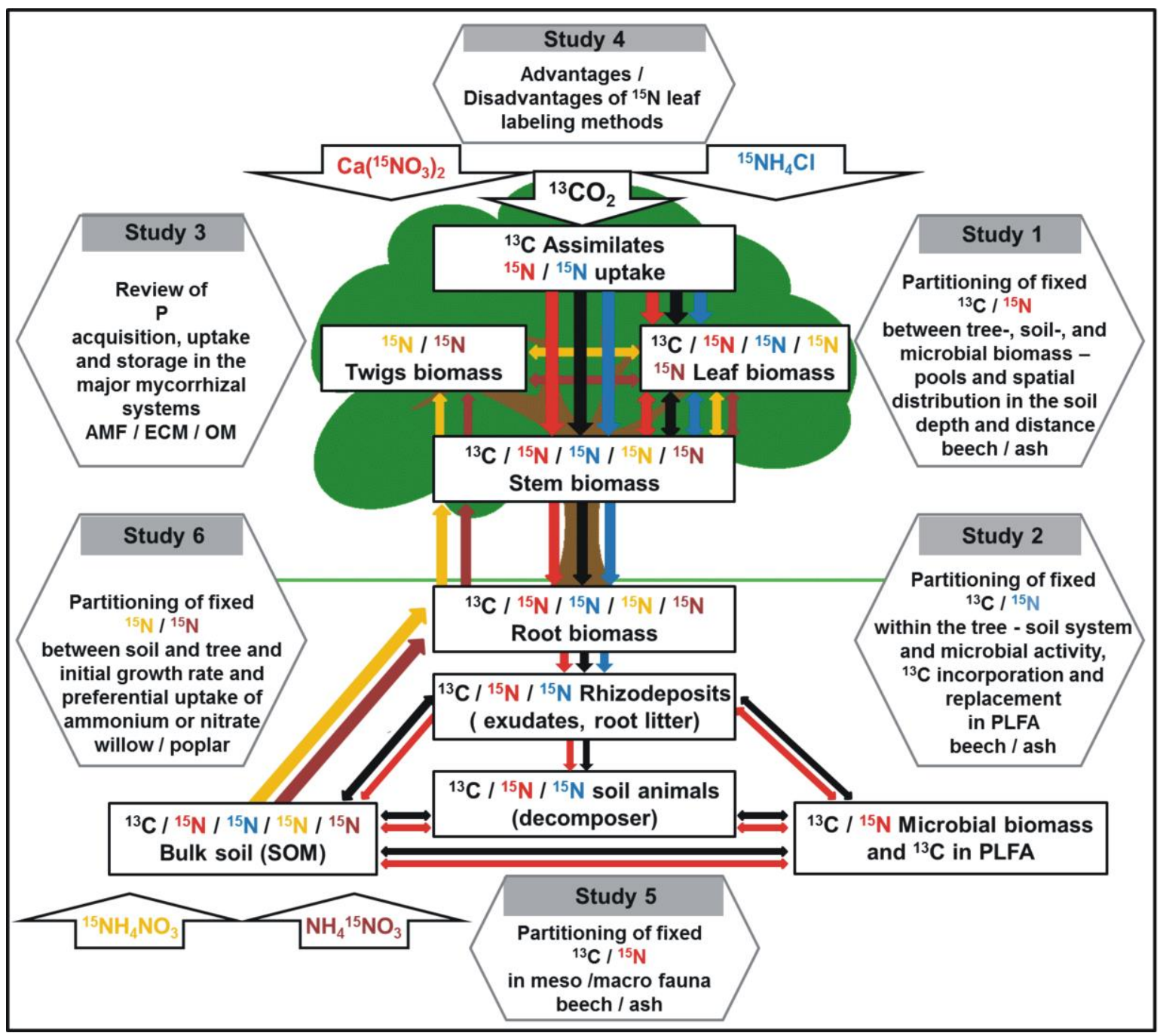

Figure 1.2-1: Overview of the studies within this thesis; Partitioning of photosynthetically fixed ${ }^{13} \mathrm{C}$ and assimilated ${ }^{15} \mathrm{~N}$ between plant and soil pools. The colors of the arrows and symbols show which fluxes and pools are quantified in the different Studies. The partitioning of ${ }^{13} \mathrm{C}$ and ${ }^{15} \mathrm{~N}$ was determined between leaf-, root-, and microbial biomass, bulk soil and soil meso- and macrofauna to determine the incorporation of assimilated $C$ and $N$ following pulse labeling into the shown pools. 


\section{$1.3 \quad$ Material and Methods}

\subsubsection{Field site description}

To gain more insight into nutrient cycles and rhizodeposition of trees the Graduiertenkolleg 1086 "The role of biodiversity for biogeochemical cycles and biotic interactions in temperate deciduous forests" was founded. The objective was to determine the importance of biodiversity for nutrient cycles and biotic interactions in trees and their rhizosphere in temperate deciduous forests. The rhizosphere is the volume of soil that is directly influenced by plant root secretions (Hiltner, 1904).

\subsubsection{Hainich National Park (Study 1, 4 and 5)}

The experiment was conducted in a temperate deciduous beech forest the Hainich National Park (Thüringen, Germany) and the experimental site $\left(10^{\circ} 05^{\prime} \mathrm{N}, 10^{\circ} 30^{\prime} \mathrm{E}, 300\right.$ AMSL) was located in the southwest of Weberstedt. The Hainich, with an area of 16000 ha, is the largest continuous and most diverse broad-leaved forest of Germany and has been declared World Heritage Nature Site in June 2011. Multiple aged deciduous trees grow there (Figure 1.3-1 B), the oldest of them having an age of at least 200 years. The forest predominantly consists of beech and the light intensity is approximately the same everywhere because the beech-dominated forest has a closed leaf cover (Figure 1.3-1 A). The mean annual temperature is $7.5 \mathrm{C}$ and the mean annual precipitation is $670 \mathrm{~mm}$. The soil at the experimental site developed from loess and was classified as Stagnic Luvisol (WRB, 2006) (Figure 1.3-1 C) that is underlaid by Triassic limestone. The forest floor is classified as mull-like moder and the mean thickness of the litter layer is 2.8 $\pm 0.1 \mathrm{~cm}$ (Langenbruch et al., 2014). The soil is characterized by a clay, slit and sand texture, $\mathrm{pH}$ values varies with the depth up to $30 \mathrm{~cm}$ from 4.2 to 4.4 (Table 1.3-1) (Guckland et al., 2009). Therefore the topsoil $(0-10 \mathrm{~cm})$ is rather acidic. The bulk density also increases with the depth from $1.2-1.5 \mathrm{~g} \mathrm{~cm}^{-3}$ (Table 1.3-1) (Guckland et al., 2009)

Table 1.3-1: General soil properties of the investigated area. Data were taken from Guckland et al. (2009)

\begin{tabular}{llllll} 
Depth $(\mathrm{cm})$ & $\mathbf{p H}\left(\mathrm{H}_{2} \mathrm{O}\right)$ & Clay $(\%)$ & Slit $(\%)$ & Sand $(\%)$ & Bulk density $\left(\mathrm{g} / \mathrm{cm}^{3}\right)$ \\
\hline $0-10$ & 4.2 & 14 & 83 & 3 & 1.2 \\
$10-20$ & 4.3 & 14 & 83 & 3 & 1.3 \\
$20-30$ & 4.4 & 14 & 82 & 4 & 1.5 \\
\hline
\end{tabular}




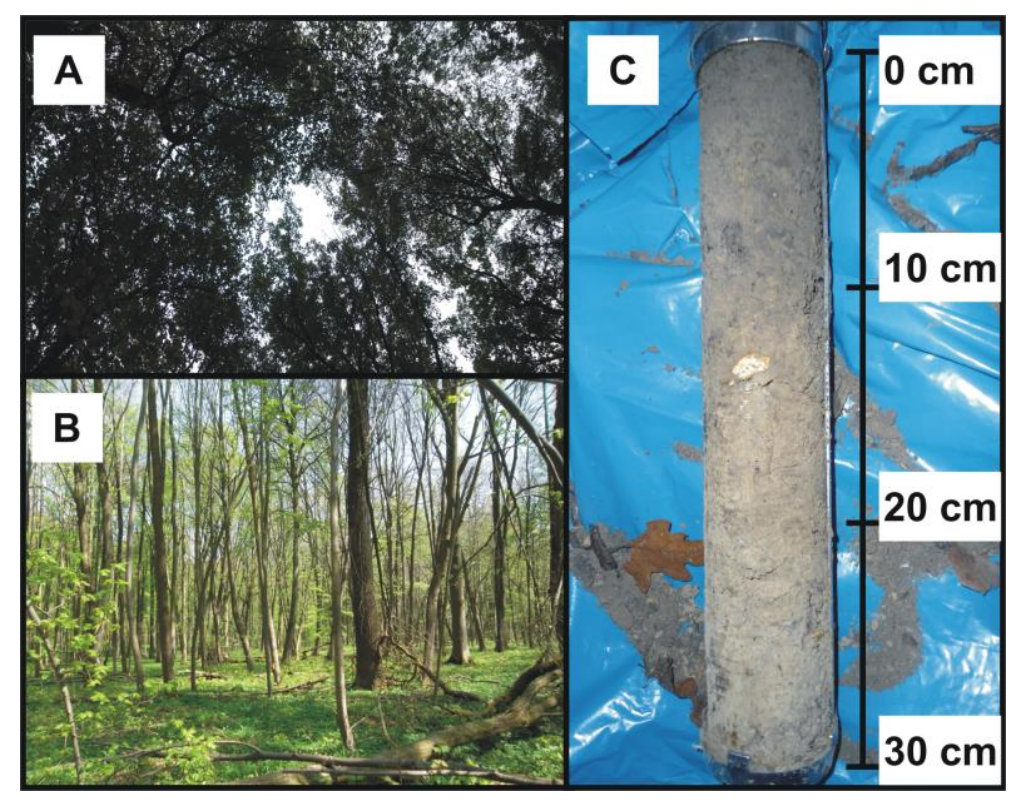

Figure 1.3-1: General conditions in the National Park Hainich; Leaf cover (A); Multiple aged trees stand (B); Stagnic Luvisol up to $30 \mathrm{~cm}$ depth (C)

\subsubsection{Göttinger Wald (Study 2 and 4)}

The trees for the experiment were taken from a temperate deciduous beech forest Göttinger Wald (51 ${ }^{\circ} 35^{\prime} 15.39 " N 9^{\circ} 58^{\prime} 57.95 " E, 362$ AMSL), located southeast of Göttingen, Lower Saxony, Germany. The climate can be described as maritime temperate (Cfb Köppen climate classification) with a mean annual precipitation of $613 \mathrm{~mm}$ and a mean annual temperature of $8.7^{\circ} \mathrm{C}$ (Scheu and Poser, 1996). The Göttinger Wald is a 130-145year-old beech forest scattered with ash and maple and is considered to present the climax stage of a temperate woodland ecosystem growing on calcareous mull soil (Scheu and Poser, 1996) (Figure 1.3-2 A). The soil is a Renzina type (Figure 1.3-2 B) type with typical mull humus and the $\mathrm{pH}$ of the topsoil varies between 4.4 and 7.0 (Maraun et al., 2001; Scheu and Poser, 1996).

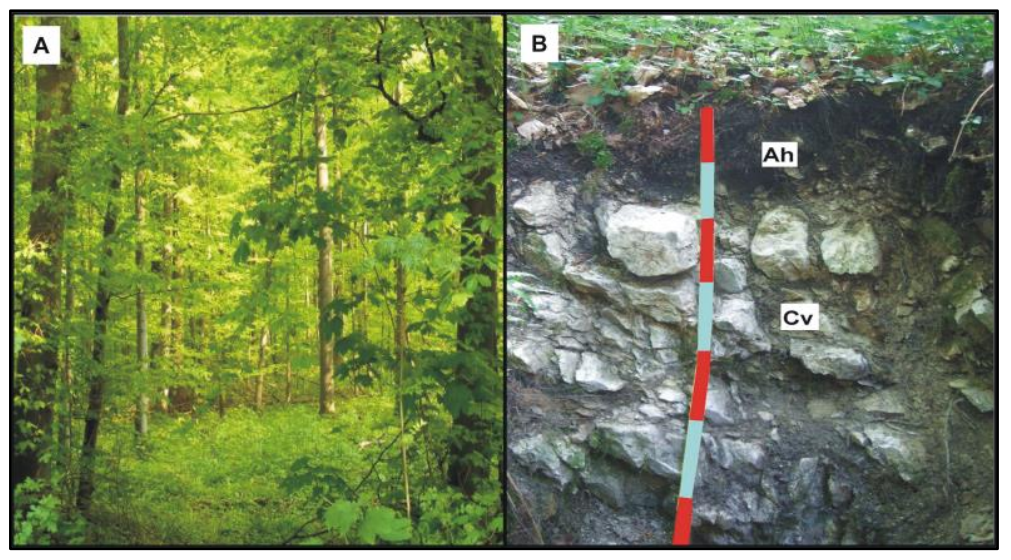

Figure 1.3-2: General conditions Göttinger Wald; Multiple aged trees stand (A); Redzina (picture from beech forest Teutoburger Wald (Begonia, 2010) 


\subsubsection{Short rotation coppice / Agroforest site Reiffenhausen (Study 6)}

The field experiment in 2011 was established as short rotation coppice and an Agroforest area in Reiffenhausen (51 ${ }^{\circ} 39^{\prime} 83^{\prime \prime} \mathrm{N} 9^{\circ} 98^{\prime} 75 " \mathrm{E}, 325$ AMSL) - located southeast of Göttingen, Lower Saxony, Germany. An area of 1.6 hectars was established with cuttings of the commercial poplar hybrid Max 1 (Populus nigra L. x P. maximowiczii Henry) and the willow varity Tortois ((Salix viminalis L. x Salix Schwerinii Wolf) x S. viminalis) in March 2011. The area was ploughed in autumn and harrowed in the winter and then divided in three parts. Two were monoculture sections of poplar and willow and one was planted as Agroforest with alternating twin rows of willow and pasture (Hartmann et al., 2014) (Figure 1.3-3). The climate can be described as maritime temperate (Cfb Köppen climate classification) with a mean annual precipitation of $642 \mathrm{~mm}$ and a mean annual temperature of $9.2{ }^{\circ} \mathrm{C}$ The soil can be characterized as loamy sand (12\% clay, $23 \%$ silt, $65 \%$ fine sand). The soil at the experimental site was classified as stagnic Cambisol (WRB, 2006) (Hartmann et al., 2014).

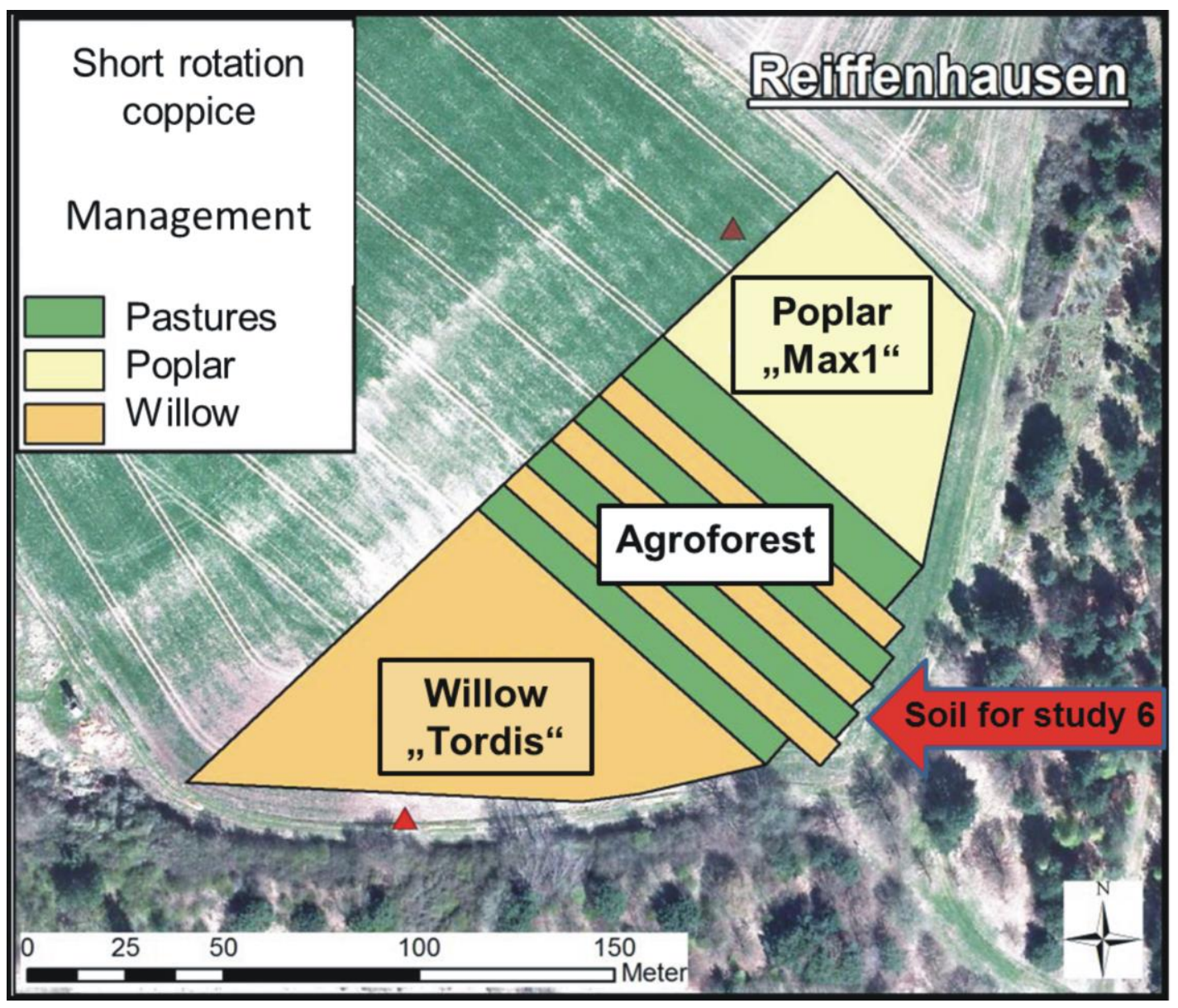

Figure 1.3-3: General set up in the short rotation coppice / agroforest site Reiffenhausen (modified Hartmann et al. 2014) 


\subsubsection{Experimental setup and realization of study 1,4 and 5}

$\mathrm{C}$ and $\mathrm{N}$ uptake and allocation in the tree and the $\mathrm{C}$ and $\mathrm{N}$ input into soil by rhizodeposition and its uptake by microorganisms and soil fauna was studied by a in situ ${ }^{13} \mathrm{CO}_{2}$ pulse labeling and $\mathrm{Ca}\left({ }^{15} \mathrm{NO}_{3}\right)_{2}$ leaf-labeling experiment.

\subsubsection{1 $\mathrm{CO}_{2}$ pulse labeling}

The ${ }^{13} \mathrm{C}$ was applied as ${ }^{13} \mathrm{CO}_{2}$ to the aboveground parts of 40 trees (3-4 m) (20 beeches, 20 ashes) by simultaneously pulse labeling for $2 \mathrm{~h}$ in individual chambers. The chambers were ca. $5 \mathrm{~m}$ high and $2.5 \mathrm{~m}$ in diameter consisting of transparent polyethylene film with a thickness of $80 \mu \mathrm{m}$ which were hung from a wooden frame and closed properly with adhesive tape to avoid gas leakage (Figure 1.3-4 A). The ${ }^{13} \mathrm{CO}_{2}$ pulse was produced by injecting $60 \mathrm{ml} 5 \mathrm{M}$ sulfuric acid $\left(\mathrm{H}_{2} \mathrm{SO}_{4}\right)$ into a solution of $100 \mathrm{ml}$ distilled water containing $6.85 \mathrm{~g}$ sodium carbonate $\left(\mathrm{Na}_{2} \mathrm{CO}_{3}\right)$ (Cambridge Isotope Laboratories, MA, USA) enriched to 99.0 atom\% ${ }^{13} \mathrm{C} .500 \mathrm{ml}$ polyethylene wide mouth bottles containing sodium carbonate were fixed to a bowl and placed inside the chamber (Figure 1.3-4 B). The chamber was then closed and sulfuric acid was carefully added from the outside into the $\mathrm{Na}_{2}{ }^{13} \mathrm{CO}_{3}$ solution using syringes, and the puncture holes caused by the syringes were sealed with tape. Sulfuric acid was added in fivefold excess to ensure complete evolution of ${ }^{13} \mathrm{CO}_{2}$. A 5-12 $\mathrm{V}$ fan inside each chamber guaranteed a uniform distribution of ${ }^{13} \mathrm{CO}_{2}$ (Figure 1.3-4 B).

\subsubsection{2 ${ }^{15} \mathrm{~N}$ labeling}

Prior to the $\mathrm{CO}_{2}$ pulse labeling, $12 \mathrm{ml}$ glass vials were used as reservoirs containing $9.7 \mathrm{ml}$ of a calcium nitrate solution. This ${ }^{15} \mathrm{~N}$ solution was made up of $36 \mathrm{~g}$ calcium nitrate (99.23 atom\% ${ }^{15} \mathrm{~N}$, Campro Scientific $\mathrm{GMbH}$, Berlin, Germany) dissolved in $1200 \mathrm{ml}$ sterilized water. Three leaves of beech and three leaflets of ash with a similar area were roughened to allow the uptake of the solution by the tree and then placed directly in the calcium nitrate solution in the vials. The vials were fixed on the branches at different heights for each tree (Figure 1.3-5 A). The vials were closed with Parafilm ${ }^{\mathrm{TM}}$ and additionally covered with a transparent bag to avoid spilling on the ground. The vials were installed on the trees three days before the $\mathrm{CO}_{2}$ labeling and were removed before the 
$\mathrm{CO}_{2}$ labeling with a cut behind the leaves to avoid contamination of the ground or other leaves.

After the labeling the tree was cut down and all leaves and the stem were separated. The stem was sampled $10 \mathrm{~cm}$ above the start of the root, in the middle of the tree. and from the top part. Than the soil was sampled $10-15 \mathrm{~cm}$ from the tree with a split tube (Figure 1.3-4 D) (diameter $7 \mathrm{~cm}$ ) in three replicates (Figure 1.3-4 C). The intact core was divided into three depth intervals $(0-10 \mathrm{~cm} ; 10-20 \mathrm{~cm} ; 20-30 \mathrm{~cm})$ and sieved to $2 \mathrm{~mm}$. Water content was determined in a subsample. Two samples of a diameter of $20 \mathrm{~cm}$ to a depth of $10 \mathrm{~cm}$ were taken per tree for the soil fauna extraction (Figure 1.3-4 C). The tree was then entirely uprooted to make sure it belongs to the labeled tree and roots were taken 10$15 \mathrm{~cm}$ from the main root. All samples were freeze tried and weighed and grounded (PM 4000, Retsch, Haan, Germany).

A summary of the material and methods used to analyzes the samples from this experiment is given in Table 1.3-2.

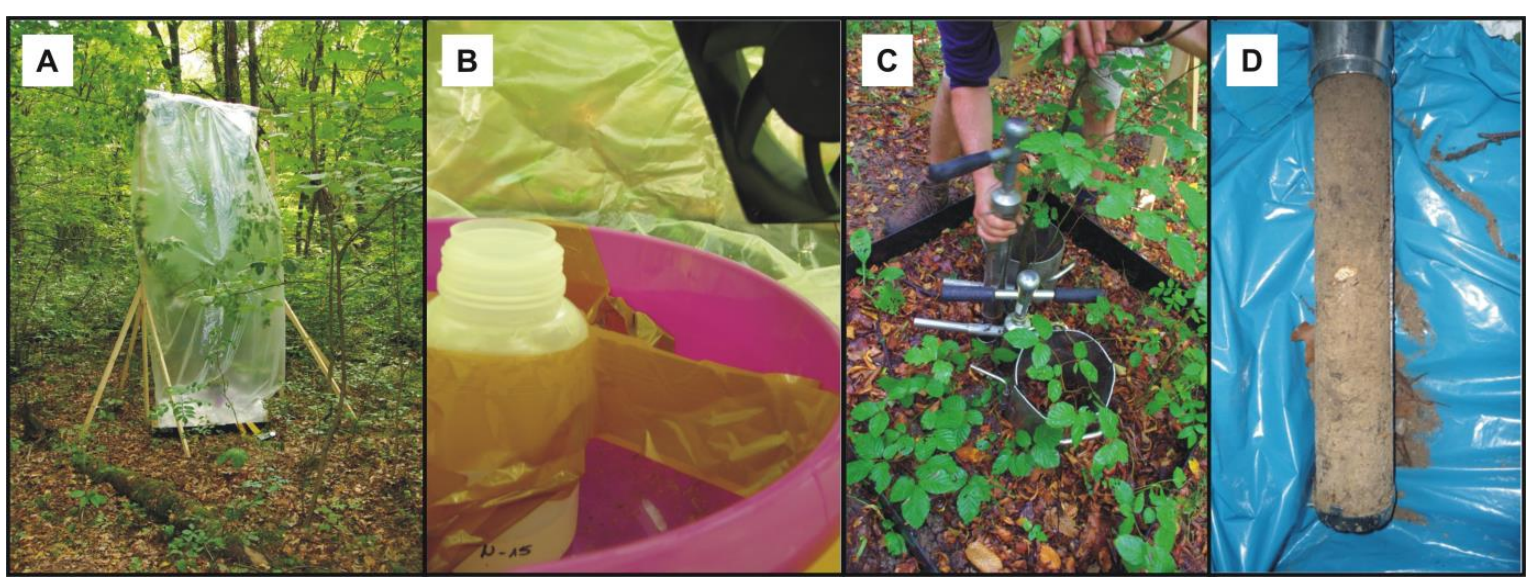

Figure 1.3-4: Chambers that were used for simultaneous in situ ${ }^{13} \mathrm{CO}_{2}$ pulse labeling of 20 replicates per tree species (A). Ventilation system inside the chamber (B); split tube for soil sampling with three replicates per tree (C), $7 \mathrm{~cm}$ soil cores taken subsequently from the soil surface down to $30 \mathrm{~cm}$ depth $(D)$. 
Table 1.3-2: Summary of the material and methods used in study 1, 4 and 5

Aims
Determination of the spatial gradients of
${ }^{15} \mathrm{~N}$ and ${ }^{13} \mathrm{C}$ allocation around the trees in
the bulk soil and microbial biomass in
three depth $(0-10 \mathrm{~cm}, 10-20 \mathrm{~cm}, 20-30$
$\mathrm{cm})$ and five different distances $(15 \mathrm{~cm}, 25$
$\mathrm{cm}, 35 \mathrm{~cm} 45 \mathrm{~cm}$ and $55 \mathrm{~cm})$ from the tree

Extraction and Sampling of soil animals to depth of $10 \mathrm{~cm}$

\section{Methods and analyzes}

Sampling of bulk soil with three replicates per tree five days after the start of the $\mathrm{CO}_{2}$ labeling

Water content was determined in a subsample.

Soil animals were extracted by heat using a high-gradient canister method (Kempson et al., 1963) and stored in concentrated salt water at $-7^{\circ} \mathrm{C}$.

Single individuals of large Oribatida were used, but for most Oribatida species several individuals had to be pooled and for Isopoda only the head was used.

$100-300 \mu \mathrm{g}$ of animal tissue were transferred into tin capsules and dried at $40{ }^{\circ} \mathrm{C}$ for $24 \mathrm{~h}$.

Determination of microbial biomass $\mathrm{C}$ and $\mathrm{N}$

Chloroform-fumigation-extraction method modified Brookes et al. (1985) and Wu et al. (1990) was used. $\mathrm{K}_{2} \mathrm{SO}_{4}$ extracts were freeze and weighed into tin capsules (> 20 $\mu \mathrm{g} C$ per capsule for fumigated samples and $>40 \mu \mathrm{g} C$ per capsule for unfumigated) for $\delta^{13} \mathrm{C}$ and $\delta^{15} \mathrm{~N}$ analysis

Extractable $\mathrm{C}_{\text {org }}$ and organic $\mathrm{N}$ in the fumigated and non-fumigated samples was measured by catalytic oxidation (Multi N/C 2100 S, Analytik Jena, Germany).

Determination of $\mathrm{C}$ and $\mathrm{N}$ partitioning, $\delta^{13} \mathrm{C}$ and $\delta^{15} \mathrm{~N}$ signature of leaf, stem and root biomass, bulk soil and microbial biomass and $\delta^{13} \mathrm{C}$ signature of bulk soil in three depth $(0-10,10-20$ and $20-30 \mathrm{~cm})$

$1,5,10,20$ and 60 days after labeling and $\delta{ }^{15} \mathrm{~N}$ signature $4,8,13,23$ and 63 days after labeling

Samples were measured by elemental analyzer NA1500 (Fison-instruments, Rodano, Milano, Italy) coupled to a Delta plus isotope ratio mass spectrometer (Finnigan MAT, Bremen, Germany) through a ConFlo III interface (Thermo Electron Corporation, Bremen, Germany) at the Centre for Stable Isotope Research and Analysis, University of Göttingen

Samples were measured by elemental analyzer NA1500 (Fison-instruments, Rodano, Milano, Italy) coupled to a Delta plus isotope ratio mass spectrometer (Finnigan MAT, Bremen, Germany) through a ConFlo III interface (Thermo Electron Corporation, Bremen, Germany) at the Centre for Stable Isotope Research and Analysis, University of Göttingen 


\subsubsection{Experimental setup and realization of study 2 and 4}

40 Ashes and 40 beeches (approx. $1 \mathrm{~m}$ ) were taken from the forest with undisturbed soil, and the entire soil core was placed into pots. After a reestablishment time of two month, the pot was wrapped with plastic and closed airtight. An irrigation system and ventilation system was established within the plastic bags. 20 ashes and 20 beeches were then ${ }^{13} \mathrm{CO}_{2}$ pulse labeled in a closed chamber (Pausch et al., 2013; Riederer et al., 2015) (Figure 1.3-5 B). Ten beech and ash trees were sampled immediately after three days labeling with ${ }^{13} \mathrm{CO}_{2}$ and two days exposure to ${ }^{12} \mathrm{CO}_{2}$ and another 20 days after the start of the $\mathrm{CO}_{2}$ labeling. The ${ }^{13} \mathrm{CO}_{2}$ pulse was produced by injecting $5 \mathrm{M}$ lactic acid into a $0.5 \mathrm{M}$ ${ }^{13} \mathrm{C}$ sodium-carbonate $\left(\mathrm{Na}_{2}{ }^{13} \mathrm{CO}_{3}\right)$ solution $\left(99{ }^{13} \mathrm{C}\right.$ atom\%Sigma-Aldrich, Traufkirchen, Germany). The trees were exposed to ${ }^{13} \mathrm{CO}_{2}$ for three days and to ${ }^{12} \mathrm{CO}_{2}$ for two days for $16 \mathrm{~h}$ day $^{-1}$ with a maximum $\mathrm{CO}_{2}$ concentration of $1800 \mathrm{ppm}$. The $\mathrm{CO}_{2}$ concentration in the

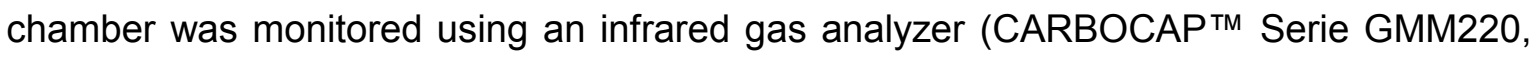
Driesen + Kern $\mathrm{GmbH}$, Bad Bramstedt, Germany). To reduce dilution of the ${ }^{13} \mathrm{CO}_{2}$ by plant-derived $\mathrm{CO}_{2}$ at night, $\mathrm{CO}_{2}$ in the chamber was absorbed by pumping the air through a $1 \mathrm{M} \mathrm{NaOH}$ solution.

The experimental setup for the leaf-labeling with ${ }^{15} \mathrm{NH}_{4} \mathrm{Cl}$ prior the $\mathrm{CO}_{2}$ labeling was comparable to study 1 (Figure 1.3-5 A). The glass vials, used in this experiment, contained ${ }^{15} \mathrm{~N}$ labeled ammonium chloride solution (98 at\% ${ }^{15} \mathrm{~N}$, Campro Scientific $\mathrm{GmbH}$, Berlin, Germany). The ${ }^{15} \mathrm{~N}$ solutions were applied per gram aboveground biomass with $3^{*} 10^{-5} \mathrm{~mol}$ per tree for $72 \mathrm{~h}$ in both experiments.

After the labeling the tree was cut down and all leaves and the stem were separated. The stem was sampled $10 \mathrm{~cm}$ above the start of the root, in the middle of the tree. and from the top part. Than the soil was sampled next to the tree with a split tube (

Figure 1.3-5 C) (diameter $7 \mathrm{~cm}$ ). The intact core was divided into two intervals $(0-10 \mathrm{~cm}$ and below $10 \mathrm{~cm}$ ) and sieved to $2 \mathrm{~mm}$ and a subsample was stored at $-20^{\circ} \mathrm{C}$ until PLFA analysis. Water content was determined in a subsample. The tree was then entirely uprooted to make sure it belongs to the labeled tree and roots were taken in different sizes. All samples were freeze tried and weighed and grounded (PM 4000, Retsch, Haan, Germany).

A summary of the material and methods used to realize the experiment is given in Table 1.3-3. 


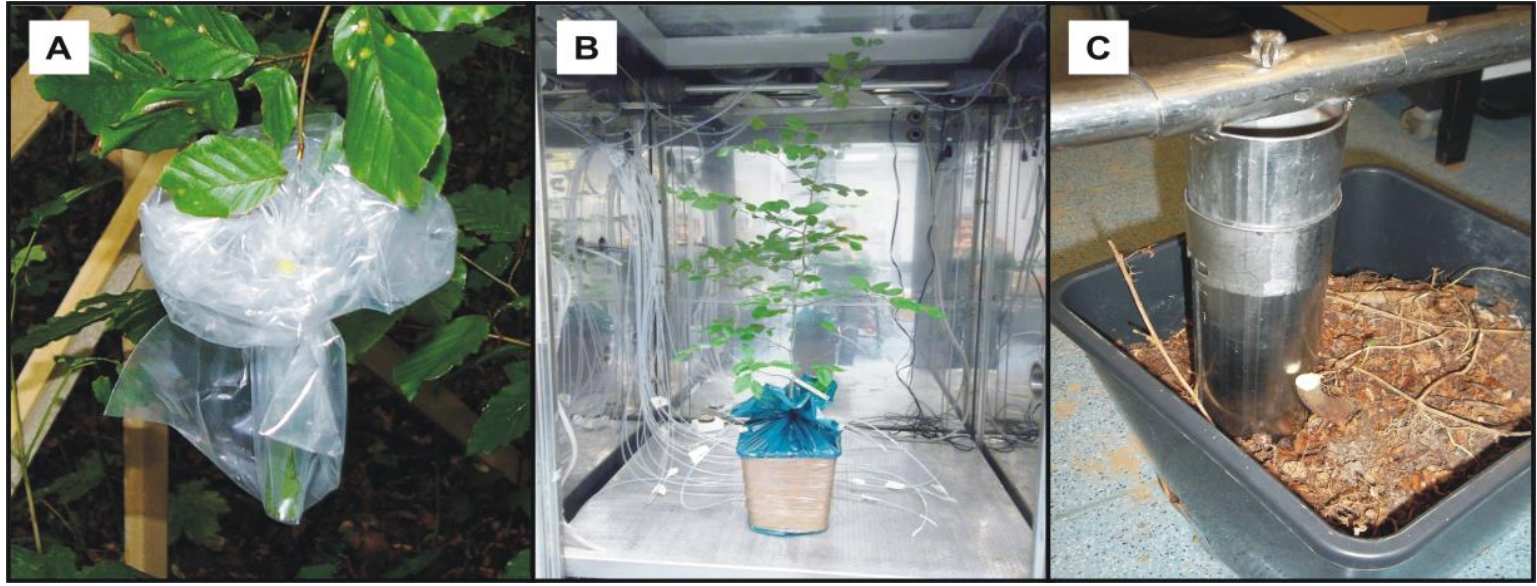

Figure 1.3-5: Setup used for ${ }^{15} \mathrm{~N}$ labeling with $\mathrm{Ca}\left({ }^{15} \mathrm{NO}_{3}\right)_{2}$ and ${ }^{15} \mathrm{NH}_{4} \mathrm{Cl}(\mathrm{A})$, labeling chamber for ${ }^{13} \mathrm{CO}_{2}$ pulse labeling of 20 replicates per tree species (B).; split tube for soil sampling $(C)$

Table 1.3-3: Summary of the material and methods used in study 2 and 4

\begin{tabular}{|c|c|}
\hline Aims & Methods and analyzes \\
\hline $\begin{array}{l}\text { - Abundance of individual } \\
\text { microbial community member to } \\
\text { be assessed by the phospholipid } \\
\text { fatty acid fingerprint (soil sample } \\
\text { from } 0-10 \mathrm{~cm} \text { depth next to the } \\
\text { tree) } 5 \text { and } 20 \text { days after the } \\
\text { start of the labeling } \\
\text { - Determination of the }{ }^{13} \mathrm{C} \text {-content } \\
\text { in the microbial groups. }\end{array}$ & $\begin{array}{l}\text { - Phospholipid extraction, purification, } \\
\text { derivatization to determining free extractable } \\
\text { fatty acids in soil. An improved method of } \\
\text { Frostegård et al. (1991) was used to extract } \\
\text { and purify phospholipids (fordetails see Study } \\
2 \text { ) } \\
\text { - The GC was coupled with a mass } \\
\text { spectrometer, for measurement of free } \\
\text { extractable fatty acids for compound } \\
\text { identification and reconstruction of microbial } \\
\text { groups (GC-MS) } \\
\text { - the gas chromatography was coupled with an } \\
\text { isotope ratio mass spectrometer for } \\
\text { determination of }{ }^{13} \text { C-content in the microbial } \\
\text { groups (GC-IRMS) } \\
\text { - Hewlett Packard } 5890 \text { GC Series II ( } 30 \text { m DB5 } \\
\text { columns (0.32 mm inner diameter and } 0.25 \\
\mu m \text { film thickness) coupled to Hewlett Packard } \\
5871 \text { mass spectrometer }\end{array}$ \\
\hline $\begin{array}{l}\text { Determine C Partitioning, } \delta^{13} \mathrm{C} \\
\text { signature of leaf biomass, stem } \\
\text { biomass, root biomass, bulk soil } \\
(0-10 \mathrm{~cm}) 5 \text { and } 20 \text { days after } \\
\text { the start of the labeling }\end{array}$ & $\begin{array}{l}\text { - Samples were measured by elemental } \\
\text { analyser NA } 1500 \text { (Fison-instruments, } \\
\text { Rodano, Milano, Italy) coupled to a Delta plus } \\
\text { isotope ratio mass spectronometer (Finnigan } \\
\text { MAT, Bremen, Germany) through a ConFlo III } \\
\text { interface (Thermo Electron Corporation, } \\
\text { Bremen, Germany) at the Centre for Stable } \\
\text { Isotope Research and Analysis, Georg-August } \\
\text { University }\end{array}$ \\
\hline
\end{tabular}




\subsubsection{Experimental setup and realization of study 6}

Pots (PVC-tubes) with a height of $30 \mathrm{~cm}$ and an inner diameter of $6.5 \mathrm{~cm}$ were filled with $4.2 \mathrm{~kg}$ soil (Figure 1.3-6). Each pot was prepared with five $5 \mathrm{~cm}$ layers containing soil amounts as given by the respective bulk densities $\left(1.2 \mathrm{~g} \mathrm{~cm}^{-3}\right)$. To obtain a uniform bulk density, each of the $5 \mathrm{~cm}$ layers was compacted separately by application of uniaxial pressure. After a reestablishment time of two month, twelve Poplar clones Max 1 (Populus nigra $x$ Populus maximowiczii) and twelve willow clones Tordis (Salix viminalis $x$ Salix schwerinii) $x$ Salix viminalis) cuttings with an average diameter of $1.2 \mathrm{~cm}( \pm 0.1 \mathrm{~cm})$ and height of $19.6 \mathrm{~cm}( \pm 0.3 \mathrm{~cm})$ were immersed into the soil. Overall 24 plants, 12 willow cuttings and 12 poplar cuttings, were grown for 49 days plus seven days after the labeling (Figure 1.3-6) and the water content was adjusted weekly by weighing and irrigating to be greater than $50 \%$ of field capacity. ${ }^{15} \mathrm{NH}_{4} \mathrm{NO}_{3}, \mathrm{NH}_{4}{ }^{15} \mathrm{NO}_{3}$ (98 atom\% ${ }^{15} \mathrm{~N}$, Campro Scientific $\mathrm{GmbH}$, Berlin, Germany) or $\mathrm{NH}_{4} \mathrm{NO}_{3}$ were applied as labeling or reference solutions with 5 $\mathrm{mg}$ of label in two $10 \mathrm{ml}$ injections in $10 \mathrm{~cm}$ soil depth per pot using a needle syringe next to the stem. No leaching of soil solution was detected during the entire experiment. The reference treatment was considered by adding the non- ${ }^{15} \mathrm{~N}$-enriched $\mathrm{NH}_{4} \mathrm{NO}_{3}$ solution. $\mathrm{A}$ summary of the material and methods used to analyze the experiment is given in Table 1.3-4.

After the labeling the tree was cut down and all leaves and the entire stem were separated. Than the soil was sampled in three intervals $(0-10 \mathrm{~cm}, 10-20 \mathrm{~cm}$ and below 20 $\mathrm{cm}$ ) and sieved to $2 \mathrm{~mm}$. Water content was determined in a subsample. The tree was then entirely uprooted to make sure it belongs to the labeled tree and roots were taken in different sizes. All leaves, stems, twigs and roots were washed after removal and dried at $60{ }^{\circ} \mathrm{C}$ to a constant mass and soil was dried at $40^{\circ} \mathrm{C}$. All samples were weighed and grounded (PM 4000, Retsch, Haan, Germany). The initial mineral nitrogen concentration was determined through $\mathrm{K}_{2} \mathrm{SO}_{4}$ extraction. $60 \mathrm{ml} 0.5 \mathrm{~mol} \mathrm{~K}_{2} \mathrm{SO}_{4}$ solution was added to 15 $\mathrm{g}$ field moist soil and shaken and filtrated, the extracts were analyzed by continuous flow injection colorimetry (Cenco/Skalar Instruments, Netherlands). The total soil nitrogen content, measured by a C-N-analyzer, (CHN-O-Rapide, VarioEL, Elementar, Hanau, Germany) was $0.6 \mathrm{mg} \mathrm{g}^{-1}( \pm 0.03)$. 


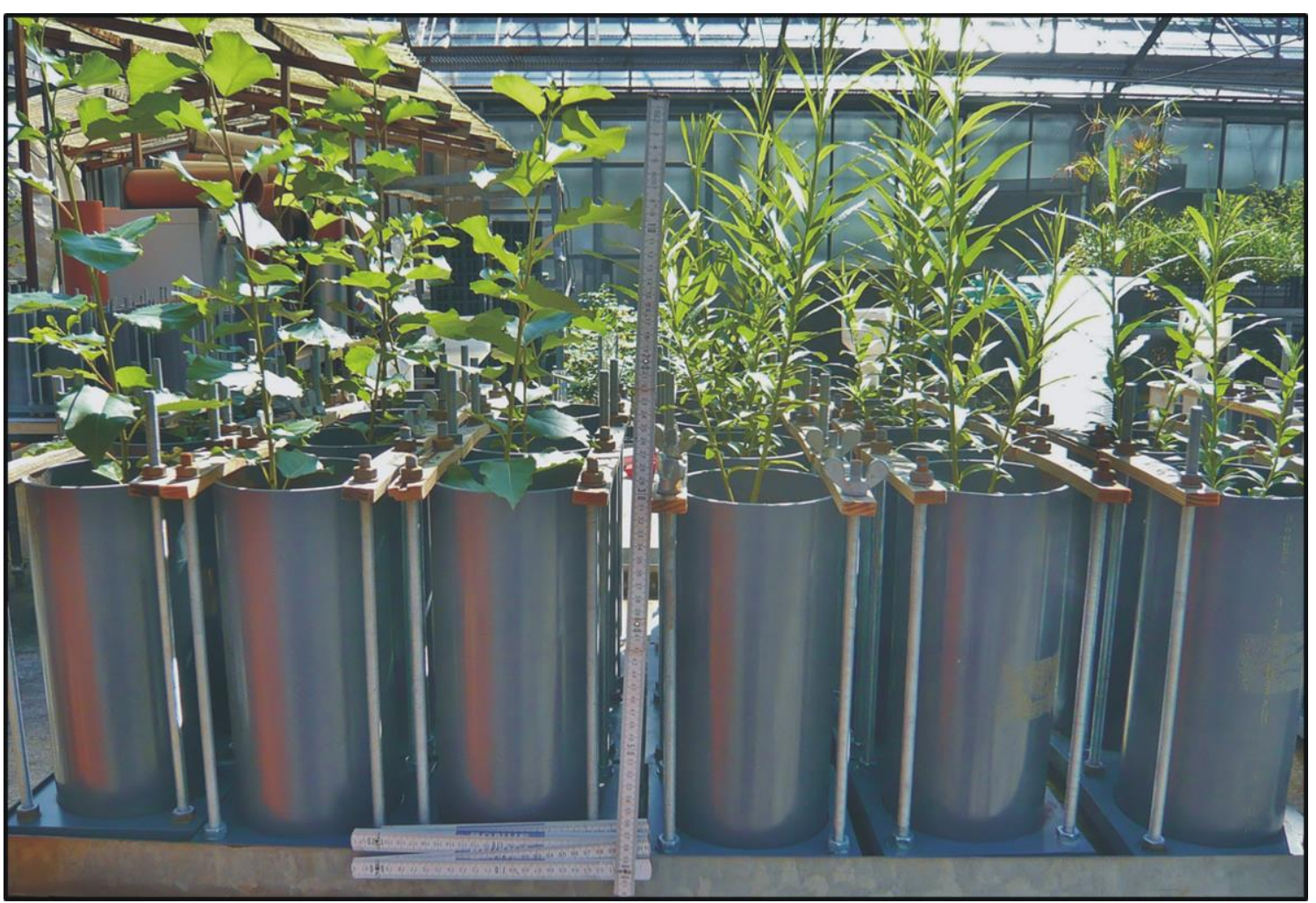

Figure 1.3-6: Setup that was used for ${ }^{15} \mathrm{~N}$ labeling of willow and poplar cuttings with ${ }^{15} \mathrm{NH}_{4} \mathrm{NO}_{3}, \mathrm{NH}_{4}{ }^{15} \mathrm{NO}_{3}$ and reference treatment with $\mathrm{NH}_{4} \mathrm{NO}_{3}$

Table 1.3-4: Summary of the material and methods usd in study 6

\begin{tabular}{l}
\hline Aims \\
\hline - Determine $\mathrm{N}$ Partitioning, $\delta$ \\
signature of leaf biomass, twig \\
biomass, stem biomass and root \\
biomass 7 days after labeling
\end{tabular}

Methods and analyzes

- 3 to $5 \mathrm{mg}$ of dried plant material were weighed into tin capsules.

- Samples were measured by elemental analyzer NA1500 (Fison-instruments, Rodano, Milano, Italy) coupled to a Delta plus isotope ratio mass spectrometer (Finnigan MAT, Bremen, Germany) through a ConFlo III interface (Thermo Electron Corporation, Bremen, Germany) at the Centre for Stable Isotope Research and Analysis, University of Göttingen

- Determine of the initial mineral $\mathrm{N}$

- $\mathrm{K}_{2} \mathrm{SO}_{4}$ extraction $60 \mathrm{ml} 0.5 \mathrm{~mol} \mathrm{~K}_{2} \mathrm{SO}_{4}$ concentration solution was added to $15 \mathrm{~g}$ field moist soil. After shaking and filtrating, the extracts were analyzed by continuous flow injection colorimetry (Cenco/Skalar Instruments, Netherlands)

- Determination of the total cation

- procedure described by Meiwes (1984) exchange capacity an $\mathrm{pH}$ of the soil was used for the total cation exchange capacity and the $\mathrm{pH}$ was measured with a digital pH-meter (inolab, WTW, Weilheim, Germany) in water and $\mathrm{KCl}$. 


\section{$1.4 \quad$ Results}

In the framework of this dissertation, a full $\mathrm{C}$ and $\mathrm{N}$ partitioning for beech and ash in deciduous forests was performed by various experimental approaches. A summarization of the main results of the flux partitioning is given in Figure 1.4-1 and studies $1-6$ are summarized in Table 1.4-6.

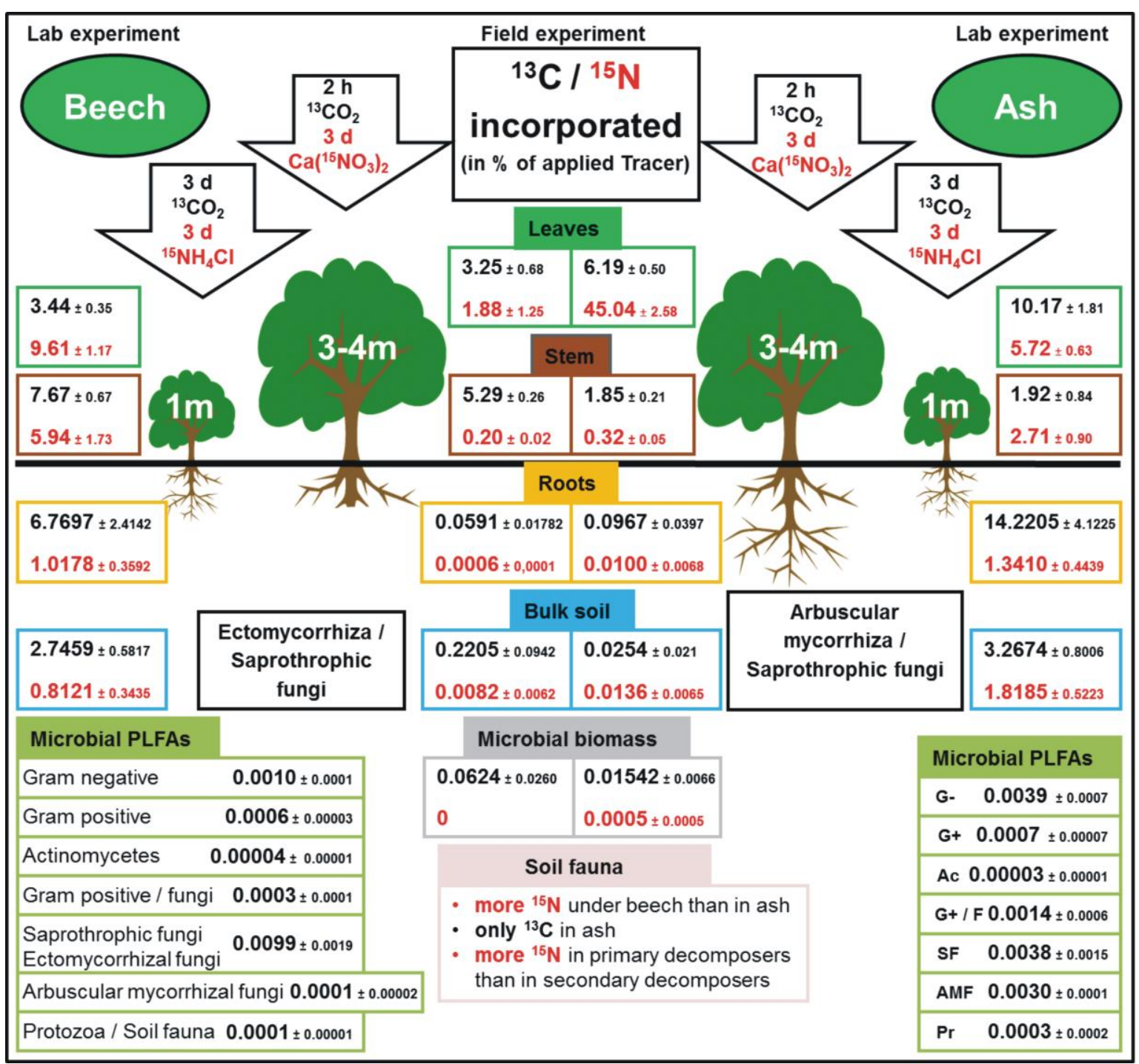

Figure 1.4-1: Summary of main results (all numbers show the incorporation in \% of the applied tracer 5 days after the labeling for $C$ values and 8 days for $N$ values; $C$ values are always displayed in black, $N$ values in red) 
Table 1.4-1: Overview of the objectives and main results of the study 1.

Study 1:

Allocation and dynamics of $\mathbf{C}$ and $\mathbf{N}$ within plant-soil system of ash and beech

\begin{tabular}{|c|c|}
\hline Objectives & Main results \\
\hline $\begin{array}{l}\text { Estimation and partitioning of } \\
\text { photosynthetically fixed } \mathrm{C} \text { between } \\
\text { two common deciduous tree } \\
\text { species, beech (Fagus sylvatica L.) } \\
\text { and ash (Fraxinus excelsior L.) into } \\
\text { different plant compartments and } \\
\text { soil/microorganisms } \\
\text { rhizodeposition, during a period of } \\
60 \text { days in summer } \\
\text { - Estimation and determination } \\
\text { of applied } \mathrm{N} \text { via leaf-labeling with } \\
\left.\text { Ca( }{ }^{15} \mathrm{NO}_{3}\right)_{2} \text { and its allocation into } \\
\text { plant compartments and soil by } \\
\text { rhizodeposition between plant and } \\
\text { soil } \mathrm{C} \text { pools and the uptake by } \\
\text { microorganisms up to a depth of } 30 \\
\text { cm } \\
\text { - } \\
\text { allocation in soil profiles of } \mathrm{C} \text { and } \mathrm{N} \\
\text { - Horizontal profiles of } \mathrm{C} \text { and } \mathrm{N} \\
\text { rhizodeposition with increasing } \\
\text { distance from the tree }\end{array}$ & $\begin{array}{l}\text { The photosynthetic } \mathrm{C} \text { assimilation is } \\
\text { twice as high in beech than in ash (beech } \\
\left.(20,2 \%) \text {, ash (9.1\%) of the applied }{ }^{13} \mathrm{CO}_{2}\right) \\
\text { - } \mathrm{N} \text { incorporation is very similar between } \\
\text { both tree species (45\% of the applied } \\
\left.\mathrm{Ca}\left({ }^{15} \mathrm{NO}_{3}\right)_{2}\right) \\
\text { - Photosynthates were transported } \\
\text { belowground more rapidly in beech than in ash } \\
\text { - Ash allocated more }{ }^{13} \mathrm{C} \text { and }{ }^{15} \mathrm{~N} \text { from the } \\
\text { above- into the belowground plant biomass and } \\
\text { accumulated }{ }^{15} \mathrm{~N} \text { and }{ }^{13} \mathrm{C} \text { in the roots. } \\
\text { - Beech released more of this initially } \\
\text { assimilated }{ }^{13} \mathrm{C} \text { (2.0\% relative }{ }^{13} \mathrm{C} \text { allocation) } \\
\text { and }{ }^{15} \mathrm{~N}\left(0.1 \% \text { relative }{ }^{15} \mathrm{~N} \text { allocation) via }\right. \\
\text { rhizodeposition into the soil than ash (0.2\% } \\
\text { relative }{ }^{13} \mathrm{C}, 0.04 \% \text { relative }{ }^{15} \mathrm{~N} \text { allocation), which } \\
\text { was also subsequently recovered in microbial } \\
\text { biomass. } \\
\text { Both tree species incorporate the most } \\
\text { B }{ }^{13} \mathrm{C} \text { into the microbial biomass of the topsoil }(0- \\
10 \mathrm{~cm}) \text { but incorporate the most }{ }^{15} \mathrm{~N} \text { in microbial } \\
\text { biomass in a soil depth of } 10-20 \mathrm{~cm} \\
\text { - }{ }^{13} \mathrm{C} \text { and }{ }^{15} \mathrm{~N} \text { allocation decreased with } \\
\text { soil depth under beech but ash allocated more } \\
{ }^{13} \mathrm{C} \text { in } 10-20 \mathrm{~cm} \text { soil } \\
\text { - }{ }^{13} \mathrm{C} \text { and }{ }^{15} \mathrm{~N} \text { tracer in the soil were } \\
\text { homogenously distributed in all soil depth along } \\
\text { the investigated distance of } 60 \mathrm{~cm} \text { from the tree }\end{array}$ \\
\hline
\end{tabular}

In summary, belowground $\mathrm{C}$ allocation of ash remained mainly in roots whereas beech released a large portion of the belowground $\mathrm{C}$ and $\mathrm{N}$ into the rhizosphere, boosting microbial activity. Whereas no lateral gradients in $\mathrm{C}$ and $\mathrm{N}$ rhizodeposition could be found there were clear vertical gradients with beech rhizodeposition dominating the first $10 \mathrm{~cm}$ of the soil, whereas ash tended to a slightly deeper maximum of rhizodeposition $(10-20 \mathrm{~cm})$. Consequently, the two tree species' strongly deviating quantity, quality and spatial distribution of $\mathrm{C}$ and $\mathrm{N}$ investment in belowground processes (quantified as $\mathrm{C}$ and $\mathrm{N}$ allocation) might be one of the mechanisms to achieve resource partitioning in the ecosystem. 
Table 1.4-2: Overview of the objectives and main results of the study 2.

Study 2

The tree species matter: Belowground carbon input and utilization in the mycosphere

\begin{tabular}{l} 
Objectives \\
\hline Comparison of the composition of \\
the microbial community structure under \\
beech (Fagus sylvatica) and ash (Fraxinus \\
excelsior) \\
- Species-specific incorporation and \\
allocation of assimilated ${ }^{13} \mathrm{C}$ into different \\
plant compartments and soil under beech \\
and ash during 20 days
\end{tabular}

- Microbial uptake and utilization of the rhizodeposits by ${ }^{13} \mathrm{C}$ incorporation into phospholipid fatty acids (PLFA), reflecting rhizodeposits utilization by the microbial community

\section{Main results}

The photosynthetic $\mathrm{C}$ assimilation is higher in ash than in beech (beech $(21 \%)$, ash $(31 \%)$ of the applied $\left.{ }^{13} \mathrm{CO}_{2}\right)$

- $\quad$ Photosynthates are transported more rapidly through the tree into the soil in beech

- $\quad$ Ash allocates twice as much ${ }^{13} \mathrm{C}$ belowground as beech until day 20

- Approximately $0.01 \%$ of the applied ${ }^{13} \mathrm{C}$ was incorporated into PLFAs of all functional microbial groups under the two species

- Microbial community structure under ash and beech is similar but incorporation varied significantly between microbial groups

- $\quad$ Saprotrophic fungi beech and ash - but also AMF and Gram negative 2 bacteria under ash - incorporated most ${ }^{13} \mathrm{C}$ and twice as much ${ }^{13} \mathrm{C}$ was incorporated into the fungal biomarker $18: 2 \omega 6,9$ under beech than under ash

- $30 \%$ of the fungal PLFA biomarker C was replaced by rhizodeposit-derived ${ }^{13} \mathrm{C}$ under beech but only $10 \%$ under ash within 5 days; none of the other microbial groups reached a similarly high $\mathrm{C}$ replacement

In summary, most of the plant-derived ${ }^{13} \mathrm{C}$ was recovered in PLFA of saprotrophic and ectomycorrhizal fungi under beech and ash but also arbuscular mycorrhizal fungi and Gram negative bacteria under ash. Furthermore, quantification of the relative $\mathrm{C}$ allocation into the different tree specific mycorrhiza types revealed that the direct $C$ allocation via mycorrhizal symbioses dominates the $\mathrm{C}$ nutrition of fungi. Consequently, the $\mathrm{C}$ cycle in forest soils strongly depends on species-specific rhizodeposition, mycorrhizal root associations and tree-species-specific $C$ turnover in the microbial groups of the rhizomycosphere. 
Table 1.4-3: Overview of the objectives and main results of the study 3.

Study 3

Mechanisms of phosphate acquisition by mycorrhiza

\begin{tabular}{|c|c|}
\hline Objectives & Main results \\
\hline $\begin{array}{l}\text { - Review of phosphorus acquisition, } \\
\text { uptake and storage in the major } \\
\text { mycorrhizal systems in plants } \\
\text { - Unravelling current state of } \\
\text { knowledge on the exchange of } \mathrm{C} \text { for } \mathrm{P} \\
\text { between plant and mycorrhiza } \\
\text { - Orchid mycorrhizas as a special } \\
\text { case were compared to the ecto- and } \\
\text { arbuscular mycorrhiza }\end{array}$ & $\begin{array}{l}\text { Mycorrhiza use biochemical, e.g. } \\
\text { chelation and acidification, biophysical } \\
\text { strategies, e.g. protoplasmic streaming } \\
\text { and occupy much larger space compared } \\
\text { to the roots to take up dissolved, and } \\
\text { mobilize sorbed, organic and mineral } P \\
\text { forms from soil behind the } P \text { depletion } \\
\text { zone of the root. } \\
\text { - mycorrhiza ensure diverse } P \\
\text { storage pools and P mobilization } \\
\text { processes and adapts rapidly to changing } \\
\text { environmental conditons } \\
\text { - Orchid mycorrhiza } \\
\text { bidirectional C and } N \text { transfer and } P \\
\text { uptake and transfer to roots } \\
\text { advantages for orchids to link via } \\
\text { ECM particularly in nutrient deficient soils } \\
\text { - ECM are more efficient in the } \\
\text { uptake and transport of } P \text {, and are able to } \\
\text { access a broader spectrum of } P \text { sources } \\
\text { compared to AM there are }\end{array}$ \\
\hline
\end{tabular}

In summary, the $\mathrm{P}$ uptake, $\mathrm{P}$ storage und transport of $\mathrm{P}$ in fungus- plant interface varies between the main mycorrhiza types (ECM, AMF). However, all types of mycorrhizal symbiosis show a rapid bidirectional transfer of $\mathrm{P}$ and carbohydrates between roots and hyphae at the fungus-root interface, which involves both, the passive efflux of $\mathrm{P}$ and carbohydrates through the fungal and plant plasma membranes into the interfacial apoplast and active exchange of nutrients between both partners. Therefore, not only the tree species-specific mycorrhizal association will impact the phosphorous uptake by the plant but also the species-specific root-derived $\mathrm{C}$ allocation. However, more research is required to assess regulation mechanism to obtain $\mathrm{P}$ from the soil in exchange for $\mathrm{C}$ from trees and to understand deviating mechanisms and function for individual species, stage of the lifecycle or in different ecosystem. 
Table 1.4-4: Overview of the objectives and main results of the study 4.

Study 4

How to decide the nitrogen leave labeling tracer for broad-leaved trees

\begin{tabular}{|c|c|}
\hline Objectives & Main results \\
\hline $\begin{array}{l}\text { - Comparison of two leaf-labeling } \\
\text { methods } \mathrm{Ca}\left({ }^{15} \mathrm{NO}_{3}\right)_{2} \text { and }{ }^{15} \mathrm{NH}_{4} \mathrm{Cl} \text { and } \\
\text { their effects on } \mathrm{N} \text { cycles in the soil- } \\
\text { plant systems } \\
\text { - Comparison of } \mathrm{N} \text { allocation patterns } \\
\text { from aboveground to belowground into } \\
\text { plant compartments and soil by } \\
\text { rhizodeposition between plant and soil } \\
\mathrm{C} \text { pools in beech and ash between the } \\
\text { two labeling methods } \\
\text { - Evaluation of the applicability for the } \\
\text { production of highly }{ }^{15} \mathrm{~N} \text { enriched litter } \\
\text { for subsequent decomposition studies } \\
\text { Evaluation of both methods for the } \\
\text { applicability in allocation studies }\end{array}$ & $\begin{array}{l}\text { - Beech and ash incorporated } \\
\text { generally more }{ }^{15} \mathrm{~N} \text { from the applied } \\
{ }^{15} \mathrm{NH}_{4} \mathrm{Cl} \text { compared to } \mathrm{Ca}\left({ }^{15} \mathrm{NO}_{3}\right)_{2} \text { in all } \\
\text { measured compartments. } \\
\text { - Ash had highest }{ }^{15} \mathrm{~N} \text { incorporation } \\
\left(45 \% \text { of the applied with } \mathrm{Ca}\left({ }^{15} \mathrm{NO}_{3}\right)_{2}\right) \text { in its } \\
\text { leaves and both tree species kept over } \\
90 \% \text { of all fixed }{ }^{15} \mathrm{~N} \text { from } \mathrm{Ca}\left({ }^{15} \mathrm{NO}_{3}\right) \text { in their } \\
\text { leaves, whereas only } 50 \% \text { of the }{ }^{15} \mathrm{~N} \text { from } \\
\text { the }{ }^{15} \mathrm{NH} \mathrm{H}_{4} \mathrm{Cl} \text { tracer remained in the leaves } \\
\text { and } 50 \% \text { were allocated to stem, roots } \\
\text { and soil. } \\
\text { - } \\
\text { salts was species-specific: the leaf- } \\
\text { labeling with }{ }^{15} \mathrm{NH} \text { incorporation fresults in a more } \\
\text { homogenous distribution between the tree } \\
\text { compartments in both tree species } \\
\text { - } \quad \text { No damage of the leaves by both } \\
\text { salts }\end{array}$ \\
\hline
\end{tabular}

In summary, both ${ }^{15} \mathrm{~N}$ tracers enable long-term labeling in situ field studies on $\mathrm{N}$ rhizodeposition and allocation in soils. However, ${ }^{15} \mathrm{NH}_{4} \mathrm{Cl}$ is more appropriate for allocation studies and leaf-labeling with $\mathrm{Ca}\left({ }^{15} \mathrm{NO}_{3}\right)_{2}$ is the more suitable method to produce highly enriched ${ }^{15} \mathrm{~N}$ leaf litter for further long term in situ decomposition and turnover studies. 
Table 1.4-5: Overview of the objectives and main results of the study 5.

Study 5

Beech trees fuel soil animal food webs via root-derived nitrogen

\begin{tabular}{l}
\hline Objectives \\
\hline Determination of root-derived C and \\
$\mathrm{N}$ for the nutrition of soil animal species \\
under young beech (Fagus sylvatica) and \\
ash (Fraxinus excelsior) trees
\end{tabular}

- $\quad$ Evaluation of the distribution of $\mathrm{C}$ and $\mathrm{N}$ in the decomposer system

\section{Main results}

- $\quad$ Higher ${ }^{15} \mathrm{~N}$ signatures in fine roots of ash as compared to beech.

- More root-derived ${ }^{15} \mathrm{~N}$ was incorporated into soil animals from the beech as compared to the ash rhizosphere

- $\quad{ }^{13} \mathrm{C}$ was only incorporated soil animals under beech

- Higher ${ }^{15} \mathrm{~N}$ signatures in primary decomposers (Porcellium conspersum Xenillus tegeocranus, Steganacarus magnus) than in secondary decomposers (Damaeus gracilipes, Damaeus riparius)

In summary, this experiment revealed that soil animal food webs rely not only on root $\mathrm{C}$ but also on root $\mathrm{N}$. While ash keeps its $\mathrm{N}$ in the roots, beech allocates it in the rhizosphere and therefore soil animals might not feed as much on the roots as on the well $\mathrm{N}$ supplied microorganisms The incorporation of ${ }^{15} \mathrm{~N}$ in the decomposers system reflects trophic levels. However, the contribution of root $\mathrm{N}$ to soil animal nutrition varies with tree species and is linked to species-specific rhizodeposition. 
Table 1.4-6: Overview of the objectives and main results of the study 6.

Study 6

Specific $\mathbf{N}_{\min }$ uptake patterns of two widely applied poplar and willow clones for short rotation coppices - implications for management practices

\begin{tabular}{|c|c|}
\hline Objectives & Main results \\
\hline $\begin{array}{l}\text { Comparison of } \mathrm{N} \text { uptake } \\
\text { from belowground between willow } \\
\text { clone Tordis and poplar clone } \\
\text { "Max 1" assessed by two labeling } \\
\text { approaches, with }{ }^{15} \mathrm{NH}_{4} \mathrm{NO} 3 \text { and } \\
\mathrm{NH}_{4}{ }^{15} \mathrm{NO}_{3} \\
\text { - Comparison of }{ }^{15} \mathrm{~N} \\
\text { allocation patterns from } \\
\text { belowground to aboveground in } \\
\text { willow and poplar and between } \\
\text { labeling approaches } \\
\text { Estimations for the } \\
\text { biomass production in } \mathrm{SRC} \text { or } \\
\text { agroforest systems for } \\
\text { subsequent applications in } \\
\text { bioenergy retrieval }\end{array}$ & 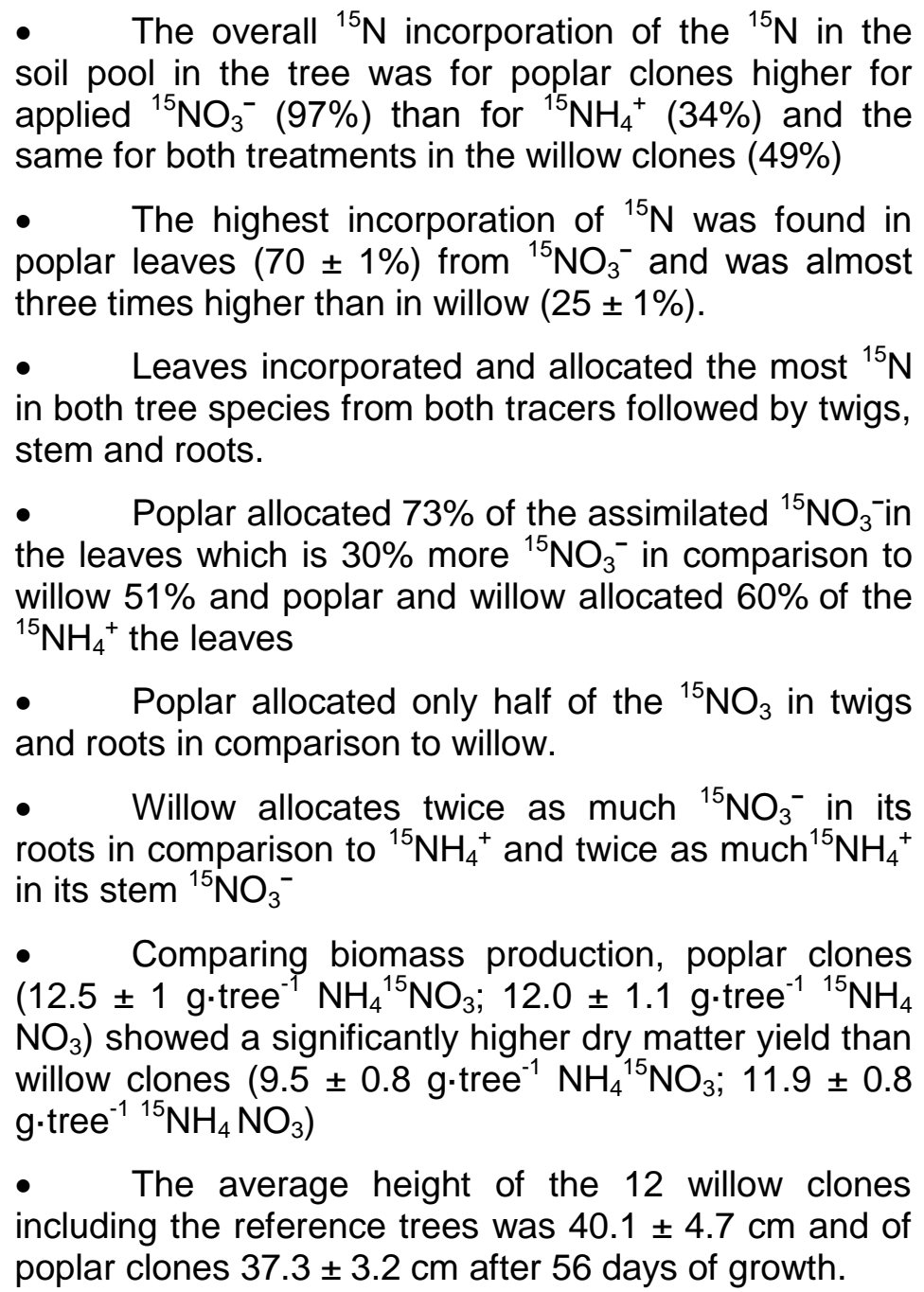 \\
\hline
\end{tabular}

In summary, the poplar hybrid is not only the better choice for biomass production but also to fix an excess of nitrate from arable fields and might be therefore more appropriate, in case of $\mathrm{N}$ surplus and high risk of $\mathrm{N}$ leaching in case of ecological considerations, e.g. in groundwater-endangered areas with intensive agriculture. All measured compartments of poplar incorporated almost all of ${ }^{15} \mathrm{NO}_{3}{ }^{-}(97 \%)$ from the $\mathrm{N}$ soil pool and only a third of the ${ }^{15} \mathrm{~N}(34 \%)$ from ${ }^{15} \mathrm{NH}_{4}{ }^{+}$. This supports support the general notion that deciduous trees prefer nitrate in contrast to conifers which are well adapted to ammonium but only in the case of poplar. Willow incorporated exactly the same amount of ${ }^{15} \mathrm{~N}$ from both tracers therefore is the preferential uptake of $\mathrm{NH}_{4}{ }^{+}$or $\mathrm{NO}_{3}{ }^{-}$might be species - specific in deciduous trees. 
The following table (Table 1.4-7) opposes literature outcomes and the novel results of this dissertation and brings the experimental context in relation to the eco-physiological knowledge on beech and ash.

Table 1.4-7: Literature knowledge of basic research in italic type and novel research in regular type

\begin{tabular}{|c|c|c|c|}
\hline & Beech & Ash & $\begin{array}{l}\text { Conditions of } \\
\text { experiments }\end{array}$ \\
\hline \multirow[t]{3}{*}{ Distribution } & $\begin{array}{l}\text { Most climatic regions of } \\
\text { Europe, most common }\end{array}$ & $\begin{array}{l}\text { European temperate } \\
\text { zone }\end{array}$ & \multirow{3}{*}{$\begin{array}{l}\text { Trees selected } \\
\text { from the } \\
\text { European } \\
\text { temperate zone, } \\
300-362 \\
\text { AMSL }\end{array}$} \\
\hline & $\begin{array}{l}\text { tree in the European } \\
\text { temperate zone (Puhe and } \\
\text { Ulrich, 2001) }\end{array}$ & \multirow[t]{2}{*}{$\begin{array}{l}\text { Up to } 1600-2000 \text { (Beck } \\
\text { et al., 2016) }\end{array}$} & \\
\hline & $\begin{array}{l}\text { Up to } 2000 \text { m (Houston } \\
\text { Durrant et al., 2016) }\end{array}$ & & \\
\hline \multirow[t]{2}{*}{$\begin{array}{l}\text { Climatic } \\
\text { constrains }\end{array}$} & $\begin{array}{l}\text { High summer } \\
\text { temperatures, }\end{array}$ & $\begin{array}{l}\text { Extended summer } \\
\text { drought, }\end{array}$ & \multirow{2}{*}{$\begin{array}{l}\text { All experiments } \\
\text { performed in the } \\
\text { range of optimal } \\
\text { climatic } \\
\text { conditions }\end{array}$} \\
\hline & $\begin{array}{l}\text { sensitive to late frosts } \\
\text { (Paule, 1995) }\end{array}$ & $\begin{array}{l}\text { seedlings vulnerable to } \\
\text { late spring frost (Beck } \\
\text { et al., 2016) }\end{array}$ & \\
\hline Stands & $\begin{array}{l}\text { Species-poor } \\
\text { multilayered forest stands } \\
\text { with beech as } \\
\text { dominating tree } \\
\text { species(Heiri et al., 2009) }\end{array}$ & $\begin{array}{l}\text { Rarely forms pure } \\
\text { stands, more often } \\
\text { small groups in mixed } \\
\text { stands(Beck et al., } \\
2016)\end{array}$ & $\begin{array}{l}\text { Experimental } \\
\text { trees taken from } \\
\text { diverse broad- } \\
\text { leaved forest }\end{array}$ \\
\hline \multirow[t]{4}{*}{$\begin{array}{l}\text { Light } \\
\text { demand }\end{array}$} & $\begin{array}{l}\text { Most shade tolerant } \\
\text { broadleaved tree in its } \\
\text { range (Praciak, 2013) }\end{array}$ & $\begin{array}{l}\text { Very light demanding } \\
\text { but shade tolerant } \\
\text { (Diekmann, 1996) }\end{array}$ & $\begin{array}{l}\text { Conditions } \\
\text { varied between } \\
\text { field and lab } \\
\text { experiment }\end{array}$ \\
\hline & \multirow[t]{2}{*}{$\begin{array}{l}\text { Higher } \mathrm{CO}_{2} \text { assimilation } \\
\left(20 \% \text { of the applied } \mathrm{CO}_{2}\right) \\
\text { one day after labeling }\end{array}$} & \multirow[t]{2}{*}{$\begin{array}{l}\text { Lower } \mathrm{CO}_{2} \text { assimilation } \\
\left(9 \% \text { of the applied } \mathrm{CO}_{2}\right) \\
\text { one day after labeling }\end{array}$} & $\begin{array}{l}\text { Field: shaded, } \\
\text { closed leaf } \\
\text { cover: }\end{array}$ \\
\hline & & & $\begin{array}{l}\text { Light intensity } \\
\text { varied between } \\
10- \\
696 \mu \mathrm{mol} \mathrm{m}{ }^{-2} \mathrm{~s}^{-1}\end{array}$ \\
\hline & $\begin{array}{l}\text { Lower } \mathrm{CO}_{2} \text { assimilation } \\
\left(21 \% \text { of the applied } \mathrm{CO}_{2}\right) \\
\text { five days after labeling }\end{array}$ & $\begin{array}{l}\text { Higher } \mathrm{CO}_{2} \text { assimilation } \\
(31 \% \text { of the applied } \\
\left.\mathrm{CO}_{2}\right) \text { five days after } \\
\text { labeling }\end{array}$ & $\begin{array}{l}\text { Laboratory: } \\
\text { Light intensity } \\
\text { was } 420 \\
\mu \mathrm{mol} \text { m-2 s- } 1\end{array}$ \\
\hline $\begin{array}{l}\text { Growth } \\
\text { height }\end{array}$ & $\begin{array}{l}30-40 \text { m, occasionally } \\
\text { reaching } 50 \text { m (Packham } \\
\text { et al., 2012) }\end{array}$ & $\begin{array}{l}20-35 \mathrm{~m} \text {, occasionally } \\
\text { reaching } 45 \mathrm{~m} \\
\text { (Ellenberg, 2009) }\end{array}$ & $\begin{array}{l}\text { Field: } 3-4 \mathrm{~m} \\
\text { Laboratory: } 1 \mathrm{~m}\end{array}$ \\
\hline
\end{tabular}




\begin{tabular}{|c|c|c|c|}
\hline $\begin{array}{l}\text { Age, } \\
\text { Fruiting }\end{array}$ & $\begin{array}{l}150 \text { - } 300 \text { years } \\
\text { Each } 5 \text { - } 8 \text { years (Houston } \\
\text { Durrant et al., 2016) }\end{array}$ & $\begin{array}{l}20 \text { to } 30 \text { years } \\
\text { fruiting annually, } \\
\text { higher production every } \\
2-5 \text { years }\end{array}$ & $\begin{array}{l}\text { 1-10 years, } \\
\text { Not fruiting }\end{array}$ \\
\hline Usage & $\begin{array}{l}\text { Wear-resistance, excellent } \\
\text { bending capabilities, fine } \\
\text { grained, knot-free, hard, } \\
\text { fire wood and charcoal, } \\
\text { used for boatbuilding, } \\
\text { flooring, stairs, furniture, } \\
\text { musical instruments, } \\
\text { plywood, panels, } \\
\text { veneering and tools } \\
\text { (Houston Durrant et al., } \\
\text { 2016) }\end{array}$ & $\begin{array}{l}\text { Elasticity, hardness, } \\
\text { and pressure, shock } \\
\text { and splintering } \\
\text { resistance, used for } \\
\text { tools, car and boat } \\
\text { frames, veneers, } \\
\text { furniture, and flooring } \\
\text { (Beck et al., 2016) }\end{array}$ & \\
\hline \multirow[t]{3}{*}{ Threads } & \multirow{3}{*}{$\begin{array}{l}\text { Herbivory (deer, weevils } \\
\text { (Strophosoma } \\
\text { melanogrammum, } \\
\text { Otiorhynchus scaber)) } \\
\text { Fungus (Ganoderma } \\
\text { applanatum, susceptible } \\
\text { hosts to Phytophthora } \\
\text { ramorum) }\end{array}$} & $\begin{array}{l}\text { Herbivory (ash borer } \\
\text { (Agrilus planipennis)) }\end{array}$ & $\begin{array}{l}\text { None at the } \\
\text { sites }\end{array}$ \\
\hline & & $\begin{array}{l}\text { Fungus (ashdieback } \\
\text { (Hymenoscyphus } \\
\text { fraxineus), Nectria } \\
\text { galligena), }\end{array}$ & \\
\hline & & $\begin{array}{l}\text { Bacterium } \\
\text { (Pseudomonas } \\
\text { syringae) }\end{array}$ & \\
\hline \multirow[t]{3}{*}{$\begin{array}{l}\text { Litter / } \\
\text { Leaves }\end{array}$} & $\begin{array}{l}\text { High C-to-N ratio (53) and } \\
\text { high lignin content ( } 85 \mathrm{mg} \\
\mathrm{g}^{-1} \text { dry matter), } \\
\text { which retards } \\
\text { decomposition } \\
\text { processes(Guckland et al., } \\
2009 ; \text { Jacob et al., 2010) }\end{array}$ & $\begin{array}{l}\text { Ash litter, in contrast, is } \\
\text { characterized by high } \\
\text { quality, low C-to- } N \text { ratio } \\
\text { (31) and low lignin } \\
\text { content ( } 25.3 \mathrm{mg} \mathrm{g}^{-1} \mathrm{dry} \\
\text { matter)(Guckland et al., } \\
\text { 2009) }\end{array}$ & \\
\hline & $\begin{array}{l}\text { Incorporated less } \\
\text { assimilated } C \text { and leaf- } \\
\text { derived } N \text { into leaves } 5 \\
\text { days after application }\end{array}$ & $\begin{array}{l}\text { Incorporated more } \\
\text { assimilated } C \text { and leaf- } \\
\text { derived } N \text { into leaves } 5 \\
\text { days after application }\end{array}$ & $\begin{array}{l}\text { Field: } 3-5 \mathrm{~m} \\
\text { high trees with a } \\
\text { leaf biomass of } \\
71 \pm 5 \mathrm{~g} \text { for } \\
\text { beech and } 45 \pm \\
3 \mathrm{~g} \text { for ash }\end{array}$ \\
\hline & $\begin{array}{l}\text { Incorporated less } \mathrm{C} \text { and } \\
\text { but more } \mathrm{N} \text { into leaves }\end{array}$ & $\begin{array}{l}\text { Incorporated more } \mathrm{C} \\
\text { and but less } \mathrm{N} \text { into } \\
\text { leaves }\end{array}$ & $\begin{array}{l}\text { Laboratory: } 1 \mathrm{~m} \\
\text { trees with a leaf } \\
\text { biomass of } 9 \pm 1 \\
\text { for beech and } 5 \\
\pm 1 \text { for ash }\end{array}$ \\
\hline
\end{tabular}




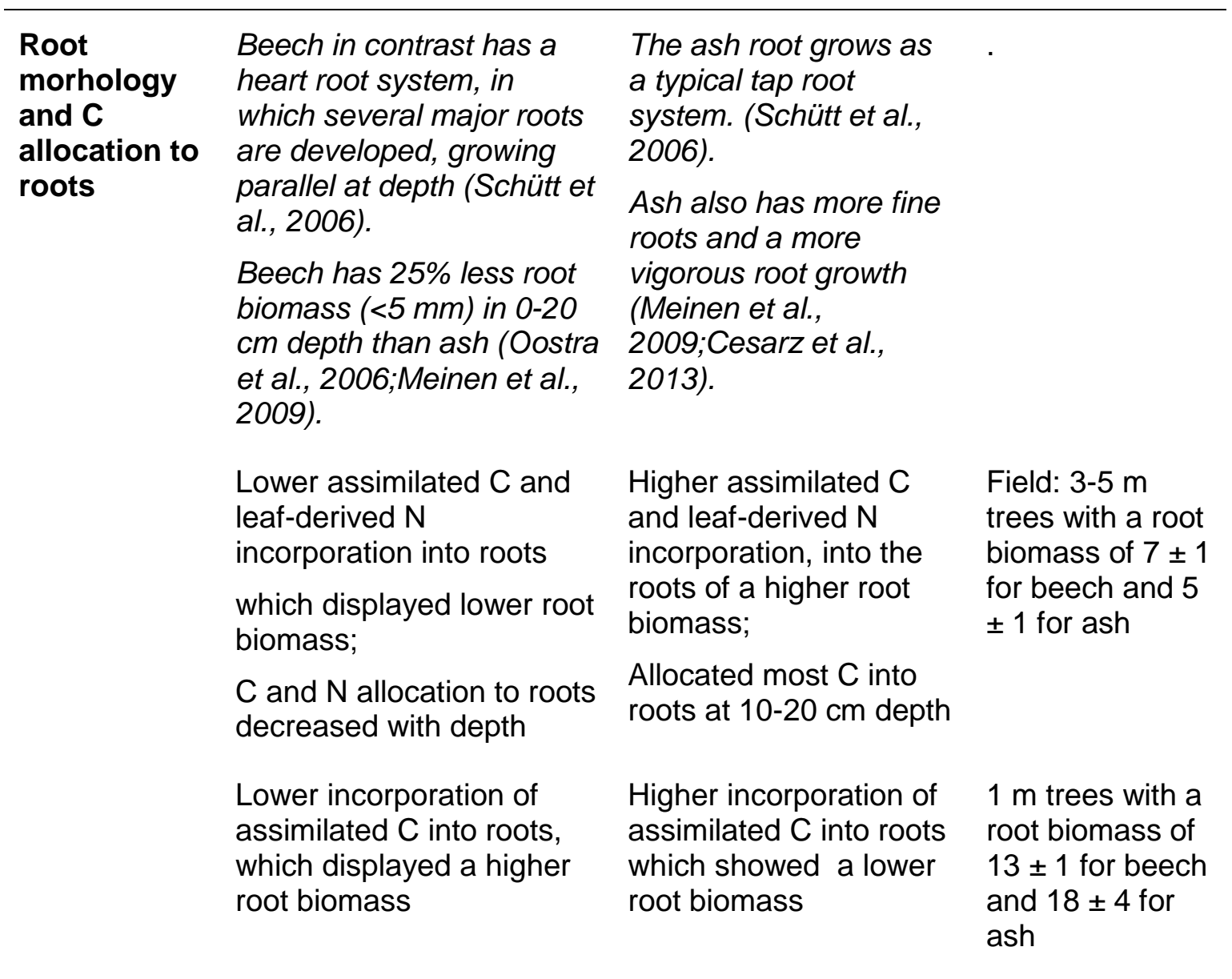

Tree species-specific root morphology was reflected in the allocation of assimilated $\mathrm{C}$ and leaf-derived $\mathrm{N}$ allocation into different soil depth

Prefers moderately fertile ground, calcified (Paule, 1995)

Similar incorporation of rhizodeposits-derived $\mathrm{C}$ into soil, but rezodepositderived $\mathrm{N}$ incorporation into soil is lower

Lower rhizodepositsderived $\mathrm{C}$ and $\mathrm{N}$ incorporation into soil
Fertile, mesic to moist slopes and alluvial ground, but also on dry soils esp. calcareous, sun-exposed slopes in beech forests (Oberdorfer, 1992)

Similar incorporation of rhizodeposits-derived C into soil but rezodeposit-derived $\mathrm{N}$ incorporation into soil is higher

Higher rhizodepositsderived $\mathrm{C}$ and $\mathrm{N}$ incorporation into soil
Field: Stagnic

Luvisol, rhizodepositsderived $\mathrm{C}$ and $\mathrm{N}$ release quantified for 3$5 \mathrm{~m}$ high trees

Laboratory:
Orthic Renzina
type with typical
mull humus
underlaid by
Triassic
limestone,
rhizoseposit-
derived C and N

Laboratory: type with typical mull humus underlaid by Triassic limestone, derived $\mathrm{C}$ and $\mathrm{N}$ 
incorporation queantified for 1

$\mathrm{m}$ high trees

The $\mathrm{C}$ and $\mathrm{N}$ cycle in forest soils strongly depends on species-specific rhizodeposition

\begin{tabular}{|c|c|c|c|}
\hline \multirow[t]{2}{*}{$\begin{array}{l}\mathrm{pH} \text { of the } \\
\text { soil }\end{array}$} & \multirow[t]{2}{*}{$\begin{array}{l}3.5-8.5 \text { (Walthert et al., } \\
2013), \text { optimum lightly } \\
\text { acidic(Paule, 1995) }\end{array}$} & \multirow[t]{2}{*}{$\begin{array}{l}>5.5 \text {, optimum } 7 \\
\text { (Dobrowolska et al., } \\
2011 \text { ) }\end{array}$} & $\begin{array}{l}\text { Field-Site: } 4.2 \\
\text { to } 4.4 \\
\text { (Guckland et } \\
\text { al., 2009) }\end{array}$ \\
\hline & & & $\begin{array}{l}\text { Laboratory Soil: } \\
4.4 \text { and } 7.0 \\
\text { (Scheu and } \\
\text { Falca, 2000) }\end{array}$ \\
\hline \multirow[t]{4}{*}{ Mycorrhiza } & \multirow{2}{*}{$\begin{array}{l}\text { Ectomycorrhizal (ECM) } \\
\text { fungi such as } \\
\text { Byssocorticium atrovirens, } \\
\text { Lactarius subdulcis and } \\
\text { Xerocomus chrysenteron, } \\
\text { which are also } \\
\text { saprothrophic (Shi et al., } \\
\text { 2002). }\end{array}$} & \multirow{3}{*}{$\begin{array}{l}\text { Arbuscular mycorrhizal } \\
\text { fungi (Meinen et al., } \\
\text { 2009); } \\
\text { Mycorrhizal colonization } \\
\text { rate is lower (Cesarz et } \\
\text { al., 2013) }\end{array}$} & \\
\hline & & & \\
\hline & \multicolumn{2}{|l|}{$\begin{array}{l}\text { Mycorrhizal colonization } \\
\text { rate is higher (Cesarz et } \\
\text { al., 2013) }\end{array}$} & \\
\hline & $\begin{array}{l}\text { Most of the plant-derived } \\
\text { C allocated into PLFA } \\
(0.010 \%) \text { was recovered } \\
\text { in PLFA of saprotrophic } \\
\text { and ectomycorrhizal fungi }\end{array}$ & $\begin{array}{l}\text { Most of the plant- } \\
\text { derived C allocated into } \\
\text { PLFA was recovered in } \\
\text { PLFA of saprotrophic } \\
\text { and ectomycorrhizal } \\
\text { fungi }(0.004 \%) \text { and } \\
\text { arbuscular mycorrhizal } \\
\text { fungi }(0.003 \%)\end{array}$ & $\begin{array}{l}\text { No inoculation - } \\
\text { natural, site- } \\
\text { specific } \\
\text { mycorrhizal } \\
\text { association was } \\
\text { established }\end{array}$ \\
\hline
\end{tabular}

The $\mathrm{C}$ and $\mathrm{N}$ cycle in forest soils strongly depends on species-specific mycorrhizal root associations and there is a direct $\mathrm{C}$ allocation via mycorrhizal symbioses which dominates the $\mathrm{C}$ flux to the rhizomicrobial community

Belowgroun
d food web
(decompose
rs and
higher
trophic
levels)

Prokaryote microorganisms suffer from the presence of beech roots due to low $\mathrm{pH}$, therefore increased fungal-to-bacterial ratio(Cesarz et al., 2013),

Micro-arthropods did not affected litter mass loss from (Lummer et al., 2012)

Higher rhizodeposits- $C \quad$ Lower rhizodeposit
Micro-arthropods affected litter mass loss from high-N ash effects of soil microarthropods are driven by litter quality (Lummer et al., 2012) 
incorporation into microbial biomass,

Higher incorporated of root-derived $\mathrm{N}$ in the soil fauna

Higher fungal to-bacterial ratio incorporation into microbial biomass,

Less root-derived $\mathrm{N}$ was incorporated in soil fauna and incorporated more ${ }^{13} \mathrm{C}$ in soil fauna

Lower fungal tobacterial ratio,

Main parts of the plantderived $\mathrm{C}$ was recovered in Gram negative bacteria under ash,

More abundant protozoa and other soil fauna members food web of 3-5

$\mathrm{m}$ trees, trenched at a $60 \mathrm{~cm}$ distance to the stem

Laboratory: Food web established after 2 month of preestablishment of the trees in a shaded area under the canopy of mature beech trees

C turnover in the microbial groups of the rhizo-mycosphere depends strongly on the tree species. Gram negatives are less relevant in rhizodeposit uptake than mycorrhizal groups in the myco-rhizosphere. Low amounts and rhizodeposit uptake of actinomycetes were present under both trees species which indicates that actinomycetes depend less on rhizodeposits and are likely SOM decomposers in broadleaf forests. More root-released $\mathrm{N}$ was incorporated in primary decomposers than in secondary decomposers 


\section{$1.5 \quad$ Conclusions}

Understanding the ecosystem functions arising from tree and soil biodiversity requires a profound knowledge of species-specific effects on forests $C$ and nutrient cycles and the interactions between above- and belowground. Study such cycles and interactions is especially challenging in forests due to high spatial heterogeneity, tall trees dominating all processes, large $\mathrm{C}$ and $\mathrm{N}$ stocks in forest soils, etc. As pool sizes in such systems react extremely slow to environmental changes, the in-situ ${ }^{13} \mathrm{C}$ and the two investigated ${ }^{15} \mathrm{~N}$ leaflabeling methods enabled successful tracing of $\mathrm{C}$ and $\mathrm{N}$ fluxes even in steady state conditions and revealed deep insights into the interactions at the plant-soil-atmosphere interface delivering a more detailed picture on the crucial role of microorganisms in this system.

In conclusion, I could prove that tree species (here beech and ash) strongly control major process of $\mathrm{C}$ and $\mathrm{N}$ cycle by their assimilation and allocation pattern. $\mathrm{C}$ and $\mathrm{N}$ dynamics above- and belowground demonstrated that rhizodeposits act as the major $\mathrm{C}$ and $\mathrm{N}$ source for microbial communities and are one way of niche differentiation in forests. A clear dominance of $\mathrm{C}$ allocation via mycorrhizal association could be found in this these and this major belowground $C$ allocation pathway is highly species-specific as beech and ash are associated with different mycorrhiza types. Special emphasis should be placed on mycorrhization in this and other natural ecosystems as fungal partners provide mechanisms overcoming limitations of key plant nutrients such as $P$ and are linked with many other microbial groups in the myco-rhizosphere mediating major processes of $\mathrm{C}, \mathrm{N}$ and $P$ dynamics. Together with higher trophic levels, fueling $C$ and nutrient cycles of mesofauna decomposer, such belowground biotic interactions are likely to increase ecological functions and improve the resilience of forest ecosystems.

Overall, this thesis contributes to the elucidation of the species-specific fate of $\mathrm{C}$ and $\mathrm{N}$ in trees, their rhizodeposits and in the soil microbial community. The presented results pushed the knowledge about $\mathrm{C}$ and $\mathrm{N}$ cycles one step further to assess the ability of forest ecosystems to sequester $\mathrm{C}$ above- and belowground and to improve conservation projects in deciduous forest systems and estimate their influence on the global C cycle. Furthermore, I considered an alternative land use system to the biomass production in deciduous forest, comparing not species and clone-specific effects on biomass production and $\mathrm{N}$ cycle. Also in such agroforestry systems, species-specifics can strongly effect the $\mathrm{N}$ cycle, but in those fast-growing systems $\mathrm{N}$ uptake preferences are a major controlling factor. Overall, SRC were identified as a promising environmental-friendly way of biomass 
production facing the raising demand of bioenergy. These results on $\mathrm{C}$ and $\mathrm{N}$ partitioning in various tree species contribute to an improved understanding of the effects speciesspecific $\mathrm{C}$ and nutrient dynamics can have on the $\mathrm{C}$ and $\mathrm{N}$ cycles in forest and agroforests. 
Allen, M. F. (1991): The Ecology of Mycorrhizae. Cambridge University Press, Cambridge.

Augusto, L., Ranger, J., Binkley, D.,Rothe, A. (2002): Impact of several common tree species of European temperate forests on soil fertility. Annals of Forest Science 59, 233-253.

Badri, D. V., Weir, T. L., van der Lelie, D., Vivanco, J. M. (2009): Rhizosphere chemical dialogues: plant-microbe interactions. Current Opinion in Biotechnology 20, 642 650.

Beck, P., Caudullo, G., Tinner, W., de Rigo, D. (2016): Fraxinus excelsior in Europe: distribution, habitat, usage and threats. Official Journal of the European Union, Luxembourg.

Begonia (2010): File:Rendzina auf Kalkstein.JPG,

Bengtson, P., Barker, J.,Grayston, S. J. (2012): Evidence of a strong coupling between root exudation, $\mathrm{C}$ and $\mathrm{N}$ availability, and stimulated SOM decomposition caused by rhizosphere priming effects. Ecology and Evolution 2, 1843-1852.

Berger, T. W., Inselsbacher, E., Mutsch, F.,Pfeffer, M. (2009a): Nutrient cycling and soil leaching in eighteen pure and mixed stands of beech (Fagus sylvatica) and spruce (Picea abies). Forest Ecology and Management 258, 2578-2592.

Berger, T. W., Untersteiner, H., Toplitzer, M.,Neubauer, C. (2009b): Nutrient fluxes in pure and mixed stands of spruce (Picea abies) and beech (Fagus sylvatica). Plant and Soil 322, 317-342.

Blagodatskaya, E.,Kuzyakov, Y. (2013): Active microorganisms in soil: Critical review of estimation criteria and approaches. Soil Biology \& Biochemistry 67, 192-211.

Bonkowski, M., Cheng, W. X., Griffiths, B. S., Alphei, G.,Scheu, S. (2000): Microbialfaunal interactions in the rhizosphere and effects on plant growth. European Journal of Soil Biology 36, 135-147.

Brookes, P. C., Landman, A., Pruden, G., Jenkinson, D. S. (1985): Chloroform fumigation and the the release of soil -nitrogen- a rapid direct extraktion method to measure microbial biomass nitogen in soil. Soil Biology \& Biochemistry 17, 837-842.

Buchmann, N., Schulze, E. D., Gebauer, G. (1995): ${ }^{15} \mathrm{~N}$ ammonium and ${ }^{15} \mathrm{~N}$ nitrate uptake of a 15-year-old Picea abies plantation. Oecologia 102, 361-370.

Cadotte, M. W. (2013): Experimental evidence that evolutionarily diverse assemblages result in higher productivity. Proceedings of the National Academy of Sciences of the United States of America 110, 8996-9000.

Cesarz, S., Fender, A. C., Beyer, F., Valtanen, K., Pfeiffer, B., Gansert, D., Hertel, D., Polle, A., Daniel, R., Leuschner, C.,Scheu, S. (2013): Roots from beech (Fagus sylvatica L.) and ash (Fraxinus excelsior L.) differentially affect soil microorganisms and carbon dynamics. Soil Biology and Biochemistry 61, 23-32.

Cheng, W. X., Parton, W. J., Gonzalez-Meler, M. A., Phillips, R., Asao, S., McNickle, G. G., Brzostek, E.,Jastrow, J. D. (2014): Synthesis and modeling perspectives of rhizosphere priming. New Phytologist 201, 31-44.

Davidson, E. A., Hart, S. C., Firestone, M. K. (1992): Internal cycling of nitrate in soils of a mature coniferous forest. Ecology 73, 1148-1156. 
Dawson, T. E., Mambelli, S., Plamboeck, A. H., Templer, P. H., Tu, K. P. (2002): Stable isotopes in plant ecology. Annual Review of Ecology and Systematics 33, 507-559.

Diekmann, M. (1996): Ecological behaviour of deciduous hardwood trees in Boreonemoral Sweden in relation to light and soil conditions. Forest Ecology and Management 86, 1-14.

Dobrowolska, D., Hein, S., Oosterbaan, A., Wagner, S., Clark, J.,Skovsgaard, J. P. (2011): A review of European ash (Fraxinus excelsior L.): implications for silviculture. Forestry.

Ellenberg, H. H. (2009): Vegetation Ecology of Central Europe. Cambridge University Press.

Finzi, A. C., Van Breemen, N.,Canham, C. D. (1998): Canopy tree soil interactions within temperate forests: Species effects on soil carbon and nitrogen. Ecological Applications 8, 440-446.

Fontaine, S.,Barot, S. (2005): Size and functional diversity of microbe populations control plant persistence and long-term soil carbon accumulation. Ecology Letters 8, 1075-1087.

Fontaine, S., Mariotti, A.,Abbadie, L. (2003): The priming effect of organic matter: a question of microbial competition? Soil Biology and Biochemistry 35, 837-843.

Frostegård, Å., Tunlid, A.,Bååth, E. (1991): Microbial biomass measured as total lipid phosphate in soils of different organic content. Journal of Microbiological Methods 14, 151-163.

Gamfeldt, L., Hillebrand, H.,Jonsson, P. R. (2008): Multiple functions increase the importance of biodiversity for overall ecosystem functioning. Ecology 89, 12231231.

Goodale, C. L., Apps, M. J., Birdsey, R. A., Field, C. B., Heath, L. S., Houghton, R. A., Jenkins, J. C., Kohlmaier, G. H., Kurz, W., Liu, S. R., Nabuurs, G. J., Nilsson, S.,Shvidenko, A. Z. (2002): Forest carbon sinks in the Northern Hemisphere. Ecological Applications 12, 891-899.

Guckland, A., Jacob, M., Flessa, H., Thomas, F. M.,Leuschner, C. (2009): Acidity, nutrient stocks, and organic-matter content in soils of a temperate deciduous forest with different abundance of European beech (Fagus sylvatica L.). Journal of Plant Nutrition and Soil Science 172, 500-511.

Harris, K. K.,Boerner, R. E. J. (1990): Effects of belowground grazing by Collembola on growth, mycorrhizal infection, and P-uptake of Geranium robertianum. Plant and Soil 129, 203-210.

Hart, S. C., Nason, G. E., Myrold, D. D.,Perry, D. A. (1994): Dynamics off gross nitrogen transformations in an old-growth forest - The carbon connection. Ecology 75, 880891.

Hartmann, L., Richter, F., Busch, G., M., E., Jansen, M.,Lamersdorf, N. (2014): Establishment of short rotation coppices in the South of Lower Saxony and in Central Thuringia in the context of the BEST-research framework - Site characteristics and initial biomass production. Forstachiv 85, 126-150.

Hector, A., Schmid, B., Beierkuhnlein, C., Caldeira, M. C., Diemer, M., Dimitrakopoulos, P. G., Finn, J. A., Freitas, H., Giller, P. S., Good, J., Harris, R., Hogberg, P., HussDanell, K., Joshi, J., Jumpponen, A., Korner, C., Leadley, P. W., Loreau, M., Minns, A., Mulder, C. P. H., O'Donovan, G., Otway, S. J., Pereira, J. S., Prinz, A., Read, D. J., Scherer-Lorenzen, M., Schulze, E. D., Siamantziouras, A. S. D., Spehn, E. M., Terry, A. C., Troumbis, A. Y., Woodward, F. I., Yachi, S.,Lawton, J. 
$H$. (1999): Plant diversity and productivity experiments in European grasslands. Science 286, 1123-1127.

Heiri, C., Wolf, A., Rohrer, L.,Bugmann, H. (2009): Forty years of natural dynamics in Swiss beech forests: structure, composition, and the influence of former management. Ecological Applications 19, 1920-1934.

Hiltner, L. (1904): Über neuere Erfahrungen und Probleme auf dem Gebiet

der Bodenbakteriologie und unter besonderer Berücksichtigung der Gründung

und Brache. Arb. Deutsch. Landwirt. Ges. 98, 59-78.

Hiol, F. H., Dixon, R. K.,Curl, E. A. (1994): The feeding preference of mycophagous collembola varies with the ectomycorrhizal symbiont. Mycorrhiza 5, 99-103.

Högberg, P., Högberg, M. N., Gottlicher, S. G., Betson, N. R., Keel, S. G., Metcalfe, D. B., Campbell, C., Schindlbacher, A., Hurry, V., Lundmark, T., Linder, S.,Nasholm, T. (2008): High temporal resolution tracing of photosynthate carbon from the tree canopy to forest soil microorganisms. New Phytologist 177, 220-228.

Holtkamp, R., van der Wal, A., Kardol, P., van der Putten, W. H., de Ruiter, P. C.,Dekker, S. C. (2011): Modelling $C$ and $N$ mineralisation in soil food webs during secondary succession on ex-arable land. Soil Biology \& Biochemistry 43, 251-260.

Hooper, D. U., Chapin, F. S., Ewel, J. J., Hector, A., Inchausti, P., Lavorel, S., Lawton, J. H., Lodge, D. M., Loreau, M., Naeem, S., Schmid, B., Setala, H., Symstad, A. J., Vandermeer, J.,Wardle, D. A. (2005): Effects of biodiversity on ecosystem functioning: A consensus of current knowledge. Ecological Monographs 75, 3-35.

Houston Durrant, T., de Rigo, D.,Caudullo, G. ( 2016): Fagus sylvatica in Europe: distribution, habitat, usage and threats. Official Journal of the European Union, Luxembourg. p. 94-95.

Hynson, N. A., Mambelli, S., Amend, A. S.,Dawson, T. E. (2012): Measuring carbon gains from fungal networks in understory plants from the tribe Pyroleae (Ericaceae): a field manipulation and stable isotope approach. Oecologia 169, 307-317.

Jacob, M., Viedenz, K., Polle, A.,Thomas, F. M. (2010): Leaf litter decomposition in temperate deciduous forest stands with a decreasing fraction of beech (Fagus sylvatica). Oecologia 164, 1083-1094.

Johnsen, K., Jacobsen, C. S., Torsvik, V.,Sorensen, J. (2001): Pesticide effects on bacterial diversity in agricultural soils - a review. Biology and Fertility of Soils 33, 443-453.

Johnson, N. C., Wilson, G. W. T., Bowker, M. A., Wilson, J. A.,Miller, R. M. (2010): Resource limitation is a driver of local adaptation in mycorrhizal symbioses. Proceedings of the National Academy of Sciences of the United States of America 107, 2093-2098.

Kanters, C., Anderson, I. C.,Johnson, D. (2015): Chewing up the Wood-Wide Web: Selective Grazing on Ectomycorrhizal Fungi by Collembola. Forests 6, 2560-2570.

Kempson, D., Lloyd, M.,Ghelardi, R. (1963): A new extractor for woodland litter. Pedobiologia 3, 1-21.

Khanna, P. K., Fortmann, H., Meesenburg, H., Eichhorn, J., Meiwes, K.-J. (2009): Biomass and element content of foliage and aboveground litterfall on the three long-term experimental beech sites: Dynamics and Significance. Springer-Verlag Berlin, Heidelberg.

Klein, T., Siegwolf, R. T. W., Körner, C. (2016): Belowground carbon trade among tall trees in a temperate forest. Science 352, 342-344. 
Korner, C., Asshoff, R., Bignucolo, O., Hattenschwiler, S., Keel, S. G., Pelaez-Riedl, S., Pepin, S., Siegwolf, R. T. W.,Zotz, G. (2005): Carbon flux and growth in mature deciduous forest trees exposed to elevated CO2. Science 309, 1360-1362.

Krome, K., Rosenberg, K., Bonkowski, M.,Scheu, S. (2009): Grazing of protozoa on rhizosphere bacteria alters growth and reproduction of Arabidopsis thaliana. Soil Biology \& Biochemistry 41, 1866-1873.

Kuzyakov, Y. (2002): Review: Factors affecting rhizosphere priming effects. Journal of Plant Nutrition and Soil Science 165, 382-396.

Langenbruch, C., Helfrich, M., Joergensen, R. G., Gordon, J.,Flessa, H. (2014): Partitioning of carbon and nitrogen during decomposition of ${ }^{13} \mathrm{C}^{15} \mathrm{~N}$-labeled beech and ash leaf litter. Journal of Plant Nutrition and Soil Science 177, 178-188.

Lennon, J. T.,Jones, S. E. (2011): Microbial seed banks: the ecological and evolutionary implications of dormancy. Nature Reviews Microbiology 9, 119-130.

Leuschner, C., Meier, I. C.,Hertel, D. (2006): On the niche breadth of Fagus sylvatica: soil nutrient status in 50 Central European beech stands on a broad range of bedrock types. Annals of Forest Science 63, 355-368.

Loreau, M.,Hector, A. (2001): Partitioning selection and complementarity in biodiversity experiments (vol 412, pg 72, 2001). Nature 413, 548-548.

Loreau, M., Naeem, S., Inchausti, P., Bengtsson, J., Grime, J. P., Hector, A., Hooper, D. U., Huston, M. A., Raffaelli, D., Schmid, B., Tilman, D., Wardle, D. A. (2001): Ecology - Biodiversity and ecosystem functioning: Current knowledge and future challenges. Science 294, 804-808.

Lukac, M., Godbold, L. D. (2011): Soil Ecology in Northern Forests: A Belowground View of a Changing World. Cambridge University Press.

Lummer, D., Scheu, S.,Butenschoen, O. (2012): Connecting litter quality, microbial community and nitrogen transfer mechanisms in decomposing litter mixtures. Oikos 121, 1649-1655.

Maraun, M., Alphei, J., Beste, P., Bonkowski, M., Buryn, R., Migge, S., Peter, M., Schaefer, M.,Scheu, S. (2001): Indirect effects of carbon and nutrient amendments on the soil meso- and microfauna of a beechwood. Biology and Fertility of Soils 34, 222-229.

Mareschal, L., Bonnaud, P., Turpault, M. P.,Ranger, J. (2010): Impact of common European tree species on the chemical and physicochemical properties of fine earth: an unusual pattern. European Journal of Soil Science 61, 14-23.

Meinen, C., Hertel, D.,Leuschner, C. (2009): Biomass and morphology of fine roots in temperate broad-leaved forests differing in tree species diversity: is there evidence of below-ground overyielding? Oecologia 161, 99-111.

Meiwes, K.-J. (1984): Chemische Untersuchungsverfahren für Mineralboden, Auflagehumus und Wurzeln zur Charakterisierung und Bewertung der Versauerung in Waldböden. Berichte des Forschungszentrums Waldökosysteme, Waldsterben 7, 142.

Metz, J., Annighofer, P., Schall, P., Zimmermann, J., Kahl, T., Schulze, E. D.,Ammer, C. (2016): Site-adapted admixed tree species reduce drought susceptibility of mature European beech. Global Change Biology 22, 903-920.

Nadelhoffer, K. J., Colman, B. P., Currie, W. S., Magill, A.,Aber, J. D. (2004): Decadalscale fates of ${ }^{15} \mathrm{~N}$ tracers added to oak and pine stands under ambient and elevated $\mathrm{N}$ inputs at the Harvard Forest (USA). Forest Ecology and Management 196, 89-107. 
Neirynck, J., Mirtcheva, S., Sioen, G.,Lust, N. (2000): Impact of Tilia platyphyllos Scop., Fraxinus excelsior L., Acer pseudoplatanus L., Quercus robur L. and Fagus sylvatica L. on earthworm biomass and physico-chemical properties of a loamy topsoil. Forest Ecology and Management 133, 275-286.

Oberdorfer, E. (1992): Teil 4- Wälder und Gebüsche. . Fischer Verlag Jena, Jena.

Oostra, S., Majdi, H.,Olsson, M. (2006): Impact of tree species on soil carbon stocks and soil acidity in southern Sweden. Scandinavian Journal of Forest Research 21, 364371.

Packham, J. R., Thomas, P. A., Atkinson, M. D.,Degen, T. (2012): Biological Flora of the British Isles: Fagus sylvatica. Journal of Ecology 100, 1557-1608.

Paquette, A.,Messier, C. (2011): The effect of biodiversity on tree productivity: from temperate to boreal forests. Global Ecology and Biogeography 20, 170-180.

Paule, L. (1995): Gene conservation in European beech (Fagus sylvatica). Forest Genetics 2, 161- 170.

Pausch, J., Tian, J., Riederer, M.,Kuzyakov, Y. (2013): Estimation of rhizodeposition at field scale: upscaling of a ${ }^{14} \mathrm{C}$ labeling study. Plant and Soil 364, 273-285.

Perry, D. A., Bell, T.,Amaranthus, M. P. (1992): The Ecology of Mixed-Species Stands of Trees. In M. G. R. Cannell, D. C. Malcolm and P. A. Robertson: Blackwell: Oxford, 151-179.

Peterson, B. J.,Fry, B. (1987): Stable isotopes in ecosystem studies. Annual Review of Ecology and Systematics 18, 293-320.

Praciak, A. (2013): The CABI encyclopedia of forest trees. C.A.B. International, Wallingford, Oxfordshire, UK ; Boston, MA.

Puhe, J.,Ulrich, B. (2001): Global climate change and human impacts on forest ecosystems. p. 181.

Remen, C., Fransson, P.,Persson, T. (2010): Population responses of oribatids and enchytraeids to ectomycorrhizal and saprotrophic fungi in plant-soil microcosms. Soil Biology \& Biochemistry 42, 978-985.

Riederer, M., Pausch, J., Kuzyakov, Y.,Foken, T. (2015): Partitioning NEE for absolute C input into various ecosystem pools by combining results from eddy-covariance, atmospheric flux partitioning and ${ }^{13} \mathrm{CO}_{2}$ pulse labeling. Plant and Soil 390, 61-76.

Rosenberg, K., Bertaux, J., Krome, K., Hartmann, A., Scheu, S.,Bonkowski, M. (2009): Soil amoebae rapidly change bacterial community composition in the rhizosphere of Arabidopsis thaliana. Isme Journal 3, 675-684.

Rothe, A.,Binkley, D. (2001): Nutritional interactions in mixed species forests: a synthesis. Canadian Journal of Forest Research-Revue Canadienne De Recherche Forestiere 31, 1855-1870.

Saetre, P., Brandtberg, P. O., Lundkvist, H.,Bengtsson, J. (1999): Soil organisms and carbon, nitrogen and phosphorus mineralisation in Norway spruce and mixed Norway spruce - Birch stands. Biology and Fertility of Soils 28, 382-388.

Scherer-Lorenzen, M., Körner, C.,Schulze, E. D. (2005): The functional significance of forest diversity: a synthesis: Forest Diversity and Function: Temperate and Boreal Systems. Springer: Berlin, Heidelberg, New York, 377-389.

Scheu, S.,Falca, M. (2000): The soil food web of two beech forests (Fagus sylvatica) of contrasting humus type: stable isotope analysis of a macro- and a mesofaunadominated community. Oecologia 123, 285-296. 
Scheu, S.,Poser, G. (1996): The soil macrofauna (Diplopoda, Isopoda, Lumbricidae and Chilopoda) near tree trunks in a beechwood on limestone: indications for stemflow induced changes in community structure. Applied Soil Ecology, 115-125.

Schmidt-Walter, P.,Lamersdorf, N. P. (2012): Biomass Production with Willow and Poplar Short Rotation Coppices on Sensitive Areas-the Impact on Nitrate Leaching and Groundwater Recharge in a Drinking Water Catchment near Hanover, Germany. BioEnergy Research 5, 546-562.

Schulz, H., Hartling, S.,Stange, C. F. (2011): Species-specific differences in nitrogen uptake and utilization by six European tree species. Journal of Plant Nutrition and Soil Science 174, 28-37.

Schulze, E. D. (2000): Carbon and Nitrogen Cycling in European Forest Ecosystems. Springer, Berlin, Heidelberg.

Schütt, P., Weisberger, H., Schuck, H. J., Lang, U. M., Stimm, B.,Roloff, A. (2006): Enzyklopädie der Laubbäume. Nikol Verlagsgesellschaft mbH \& Co KG, Hamburg.

Shi, L. B., Guttenberger, M., Kottke, I.,Hampp, R. (2002): The effect of drought on mycorrhizas of beech (Fagus sylvatica L.): changes in community structure, and the content of carbohydrates and nitrogen storage bodies of the fungi. Mycorrhiza 12, 303-311.

Spehn, E. M., Hector, A., Joshi, J., Scherer-Lorenzen, M., Schmid, B., Bazeley-White, E., Beierkuhnlein, C., Caldeira, M. C., Diemer, M., Dimitrakopoulos, P. G., Finn, J. A., Freitas, H., Giller, P. S., Good, J., Harris, R., Hogberg, P., Huss-Danell, K., Jumpponen, A., Koricheva, J., Leadley, P. W., Loreau, M., Minns, A., Mulder, C. P. H., O'Donovan, G., Otway, S. J., Palmborg, C., Pereira, J. S., Pfisterer, A. B., Prinz, A., Read, D. J., Schulze, E. D., Siamantziouras, A. S. D., Terry, A. C., Troumbis, A. Y., Woodward, F. I., Yachi, S.,Lawton, J. H. (2005): Ecosystem effects of biodiversity manipulations in European grasslands. Ecological Monographs 75, 37-63.

Sulzman, E. W. (2007): Stable isotope chemistry and measurement: a primer. Blackwell Publishing, Oxford.

Thünen-Institut, J. H. v. (2012): Dritte Bundeswaldinventur: Braunschweig, https://bwi.info/start.aspx.

Tilman, D., Wedin, D.,Knops, J. (1996): Productivity and sustainability influenced by biodiversity in grassland ecosystems. Nature 379, 718-720.

van der Heijden, M. G. A., Klironomos, J. N., Ursic, M., Moutoglis, P., Streitwolf-Engel, R., Boller, T., Wiemken, A.,Sanders, I. R. (1998): Mycorrhizal fungal diversity determines plant biodiversity, ecosystem variability and productivity. Nature 396, 69-72.

van Kessel, C., Clough, T.,van Groenigen, J.-W. (2009): Dissolved Organic Nitrogen: An Overlooked Pathway of Nitrogen Loss from Agricultural Systems? Journal of Environmental Quality 38, 393-401.

Vesterdal, L., Schmidt, I. K., Callesen, I., Nilsson, L. O.,Gundersen, P. (2008): Carbon and nitrogen in forest floor and mineral soil under six common European tree species. Forest Ecology and Management 255, 35-48.

Vitousek, P. M.,Howarth, R. W. (1991): Nitrogen limitation on land and in the sea: How can it occur? Biogeochemistry 13, 87-115.

von Lützow, M., Kögel-Knabner, I., Ekschmitt, K., Matzner, E., Guggenberger, G., Marschner, B., Flessa, H. (2006): Stabilization of organic matter in temperate soils: mechanisms and their relevance under different soil conditions - a review. European Journal of Soil Science 57, 426-445. 
Wallander, H., Ekblad, A.,Bergh, J. (2011): Growth and carbon sequestration by ectomycorrhizal fungi in intensively fertilized Norway spruce forests. Forest Ecology and Management 262, 999-1007.

Walthert, L., Graf Pannatier, E.,Meier, E. S. (2013): Shortage of nutrients and excess of toxic elements in soils limit the distribution of soil-sensitive tree species in temperate forests. Forest Ecology and Management 297, 94-107.

WRB (2006): World Reference Base for Soil Resources 2006. FAO, Rome, Italy.

Wu, J., Joergensen, R. G., Pommerening, B., Chaussod, R.,Brookes, P. C. (1990): Measurement of soil microbial biomass $C$ by fumigation extraction- an automated procedure. Soil Biology \& Biochemistry 22, 1167-1169.

$W u$, J. G. (2013): Landscape sustainability science: ecosystem services and human wellbeing in changing landscapes. Landscape Ecology 28, 999-1023.

Wu, J. G., Naeem, S., Elser, J., Bai, Y. F., Huang, J. H., Kang, L., Pan, Q. M., Wang, Q. B., Hao, S. G.,Han, X. G. (2015): Testing biodiversity-ecosystem functioning relationship in the world's largest grassland: overview of the IMGRE project. Landscape Ecology 30, 1723-1736.

Zwart, K. B., Kuikman, P. J.,Van Veen, J. A. (1994): Rhizosphere protozoa: their significance in nutrient dynamics. CAB International, Wallingford. 
Chapter 2

\section{Publications and Manuscripts}




\section{Study 1}

\subsection{Allocation and dynamics of $\mathrm{C}$ and $\mathrm{N}$ within plant-soil system of ash and beech}

JANINE SOMMER ${ }^{1}$, MICHAELA A. DIPPOLD ${ }^{2}$, HEINZ FLESSA $^{3}$, YAKOV KUZYAKOV ${ }^{1,2}$,

${ }^{1}$ Soil Science of Temperate Ecosystems, Georg-August-University Göttingen, 37077 Göttingen, Germany

${ }^{2}$ Agricultural Soil Science, Georg-August-University Göttingen, 37077 Göttingen, Germany

${ }^{3}$ Institute of Climate-Smart Agriculture, Thünen Institute, 38116 Braunschweig, Germany

"corresponding author

Department of Soil Science of Temperate Ecosystems, Georg-August-University Göttingen, 37077 Göttingen, Germany

Phone: + 49(0)157 $73857055 \quad$ Fax $+49(0) 551393310$

email: sommer.janine@yahoo.de

Published in Journal of Plant Nutrition and Soil Science

April 2016, Vol 179, Issue 3, Pages: 376-387

DOI: 10.1002/jpln.201500384

The final publication is available at

http://onlinelibrary.wiley.com/doi/10.1002/jpln.201500384/full 


\section{Abstract}

Forest management requires a profound understanding of how tree species affect carbon (C) and nitrogen $(\mathrm{N})$ cycles in ecosystems. The large $\mathrm{C}$ and $\mathrm{N}$ stocks in forest soils complicate research on the effects of tree species on $\mathrm{C}$ and $\mathrm{N}$ pools. In-situ ${ }^{13} \mathrm{C}$ and ${ }^{15} \mathrm{~N}$ labeling in undisturbed, natural forests enable not only tracing of $\mathrm{C}$ and $\mathrm{N}$ fluxes, but also reveal insight into the interactions at the plant-soil-atmosphere interface.

In-situ dual ${ }^{13} \mathrm{C}$ and ${ }^{15} \mathrm{~N}$ pulse labeling of 20 beeches (Fagus sylvatica L.) and 20 ashes (Fraxinus excelsior L.) allowed tracing of the fate of assimilated $\mathrm{C}$ and $\mathrm{N}$ in trees and soils in an unmanaged forest system in the Hainich National Park. Leaf, stem, root and soil samples as well as microbial biomass were analyzed to quantify the allocation of ${ }^{13} \mathrm{C}$ and ${ }^{15} \mathrm{~N}$ for 60 days after labeling and along spatial gradients in the soil with increasing distance from the stem.

For trees of similar heights ( $4 \mathrm{~m})$, beech (20\%) assimilated twice as much as ash (9\%) of the applied ${ }^{13} \mathrm{CO}_{2}$, but beech and ash incorporated similar ${ }^{15} \mathrm{~N}$ amounts (45\%) into leaves. The photosynthates were transported belowground through the phloem more rapidly in beech than in ash. Ash preferentially accumulated ${ }^{15} \mathrm{~N}$ and ${ }^{13} \mathrm{C}$ in the roots. In contrast, beech released more of this initially assimilated ${ }^{13} \mathrm{C}\left(2.0 \%\right.$ relative ${ }^{13} \mathrm{C}$ allocation $)$ and ${ }^{15} \mathrm{~N}\left(0.1 \%\right.$ relative ${ }^{15} \mathrm{~N}$ allocation) via rhizodeposition into the soil than ash $(0.2 \%$ relative ${ }^{13} \mathrm{C}, 0.04 \%$ relative ${ }^{15} \mathrm{~N}$ allocation), which was also subsequently recovered in microbial biomass. These results on $\mathrm{C}$ and $\mathrm{N}$ partitioning contribute to an improved understanding of the effects of European beech and ash on the $\mathrm{C}$ and $\mathrm{N}$ cycles in deciduous broad-leaved forest. Differences in $\mathrm{C}$ and $\mathrm{N}$ allocation patterns between ash and beech are one mechanism of niche differentiation in forests containing both species.

Key-words: ${ }^{13} \mathrm{CO}_{2}$ labeling, $\mathrm{Ca}\left({ }^{15} \mathrm{NO}_{3}\right)_{2}$; carbon and nitrogen cycles, tree rhizodeposition; species effects, deciduous forest 


\subsubsection{Introduction}

Soil organic carbon (SOC) and its turnover play a crucial role in sustainable forest management and for mitigation of greenhouse gas $\left(\mathrm{CO}_{2}\right)$ emissions. Forest $\mathrm{C}$ and $\mathrm{N}$ budgets affect tree growth, the acquisition of resources such as light, nutrients and water and consequently forest productivity of standing biomass and $C$ sequestration in soil organic matter (Litton et al., 2007). The government forestry department is conducting a broad-scale conversion of monocultures to mixed forest stands in Germany and, therefore, the impact of tree species diversity on the chemical, physical and biological characteristics of soil is of particular interest. Where forests have been considered in previous research, the focus has been on soil biochemical properties of conifers, rather than deciduous trees. (Augusto et al., 2002; Berger et al., 2009a; Berger et al., 2009b; Mareschal et al., 2010). Mareschal et al. (2010) showed for three conifers and beech that they affect various chemical properties of topsoil and have an impact on soil fertility. Schleuß (2014) also showed for the first time that mixed forests with mainly beech are superior with respect to $\mathrm{C}_{\text {org }}$ stabilization in the clay and fine silt fractions of the subsoil compared with monospecific beech forests. He also pointed to a pronounced species identity and/or diversity effect on soil $\mathrm{C}$ storage in an old growth forest with near steady state soil conditions. However, large differences between various broad-leaved species in $\mathrm{C}$ and $\mathrm{N}$ allocations can be expected, considering their niche differentiation concerning light acquisition, nutrient uptake, interactions with mycorrhiza types and soil morphology. The effects of these differences on $\mathrm{C}$ and $\mathrm{N}$ allocations have not been analyzed to date.

$\mathrm{N}$ fluxes in the xylem of trees are regulated by three processes: remobilization from internal reserves, root uptake of $\mathrm{N}$ from the soil, and phloem-xylem recycling (Dambrine et al., 1995; Grassi et al., 2003). Trees are rarely C limited and tree growth is mostly limited by $\mathrm{N}$ availability (Millard and Grelet, 2010). Trees accumulate large amounts of $\mathrm{C}$ as non-structural carbohydrates and lipids (Wurth et al., 2005) and the processes regulating the storage of an abundant resource like $\mathrm{C}$ are quite different from the seasonal allocation of scarce resources such as $\mathrm{N}$. Remobilization of stored $\mathrm{N}$ in the tree biomass is essential for the growth of temperate deciduous trees, especially in spring, and the relative contributions of remobilized $\mathrm{N}$ and $\mathrm{N}$ taken up by roots to the $\mathrm{N}$ used for growth depends on tree age, soil fertility and other environmental factors (Millard, 1996; Dyckmans and Flessa, 2001). Regulation of $\mathrm{N}$ uptake by roots could involve shoot-root cycling of $\mathrm{N}$, because an inverse correlation has been found between the concentrations of amino acids and amides in phloem sap and nitrate uptake by the roots of beech (Gessler et al., 1998), and Prunus persica (Youssefi et al., 2000). We hypothesize that 
there are species-specific patterns of $\mathrm{C}$ and $\mathrm{N}$ allocation in the tree compartments due to differences in remobilization and recycling processes and, therefore, differences in the amount of rhizodeposition into the soil.

Beech and ash differ considerably in their mycorrhizal association. Beech is associated with ectomycorrhiza while ash associates with arbuscular mycorrhiza (Meinen et al., 2009). A rapid transfer of photosynthates to ectomycorrhiza has indeed been reported (Leake et al., 2001; Esperschütz et al., 2009; Hogberg et al., 2010). Callesen et al. (2013) discovered in ash and beech that the $\delta^{15} \mathrm{~N}$ pattern reflected tree species-related traits affecting the $\mathrm{N}$ cycling as well as site fertility and former land use, and possibly differences in $\mathrm{N}$ leaching. They also mentioned that the tree species $\delta^{15} \mathrm{~N}$ patterns reflected fractionation caused by uptake of $\mathrm{N}$ through mycorrhiza rather than due to nitrate leaching or other $\mathrm{N}$ transformation processes. We also hypothesize differences in the $\mathrm{C}$ and $\mathrm{N}$ allocation patterns between beech and ash. We also expect beech to be more rapid in its allocation of $\mathrm{C}$ and $\mathrm{N}$ through the tree compartments, belowground and more prolific in its rhizodeposition than ash. Furthermore beech and ash differ in their root morphology. The ash root grows as a typical tap root system. Beech in contrast has a heart root system, in which several major roots are developed, growing parallel at depth (Schütt et al., 2006). Therefore we expect differences in the ${ }^{13} \mathrm{C}$ and ${ }^{15} \mathrm{~N}$ allocation between beech and ash at different depths. We assume that beech shows depth-related rhizodeposition while ash might exhibit a peak in $\mathrm{C}$ and $\mathrm{N}$ deposition at a certain depth.

Bauhus et al. (1998) reported that microbial biomass is on average lower in forest floor beneath conifers than beneath deciduous species and concluded that microbial variables are sensitive to tree species, stand age and soil type. However, they did not explore to what extent the trees directly affect soil $\mathrm{C}$ and $\mathrm{N}$ turnover and microbial biomass through their rhizodeposits. Quantifying the C flux from plant shoots to roots is necessary in order to estimate the contribution of recently fixed plant photosynthates to ecosystem $\mathrm{C}$ cycling and microbial biomass (Ostle et al., 2000; Rangel-Castro et al., 2004). Tracing photosythetically assimilated $\mathrm{C}$ after ${ }^{13} \mathrm{CO}_{2}$ labeling and observing the subsequent ${ }^{13} \mathrm{C}$ flux through rhizodeposition into soil and microbial communities is a powerful tool for the investigation of $C$ turnover in forest soils (Potthoff et al., 2003). To date, there have been very few studies using labeling of trees under field conditions to investigate $\mathrm{C}$ and $\mathrm{N}$ turnover in soil (Högberg et al., 2008; Epron et al., 2011; Shibistova et al., 2012). Nevertheless, field studies on the $\mathrm{C}$ flux from the tree canopy to belowground are necessary because laboratory mesocosms may not realistically reproduce the complexity and dynamics found in the field, especially in the case of forests (Högberg et al., 2008). Furthermore, long-term experiments are necessary to achieve a more complete understanding of $\mathrm{C}$ and $\mathrm{N}$ cycling in forest ecosystems. 
The aim of this study was to quantify $\mathrm{C}$ and $\mathrm{N}$ allocation into plant compartments of beech and ash and to investigate whether there is a species effect on the surrounding soil and microbial biomass and its $\mathrm{C}$ gain from the tree. Generally, two approaches for dual isotope labelling of plants are possible: (i) using natural pathways of $\mathrm{CO}_{2}$ assimilation by photosynthesis and $\mathrm{N}$ uptake from soil or (ii) transfer of $\mathrm{C}_{\text {org }}$ and $\mathrm{N}$ into the stem of plants by passive uptake through transpiration flow (Wichern et al., 2011). However, it is not known how the applied $\mathrm{C}$ and $\mathrm{N}$ isotopes are distributed within a deciduous tree, or whether dual isotope labeling also works for medium-sized trees under field conditions in a temperate forest ecosystem. We therefore conducted an in-situ pulse-labeling experiment using ${ }^{13} \mathrm{C}$ and ${ }^{15} \mathrm{~N}$ to investigate the $\mathrm{C}$ and $\mathrm{N}$ allocation from the atmosphere via the plant compartments into soil by two broad-leaved tree species: beech (Fagus sylvatica) and ash (Fraxinus excelsior). 


\subsubsection{Material and Methods}

\subsubsection{Site description}

The experimental site $\left(10^{\circ} 05^{\prime} \mathrm{N}, 10^{\circ} 30^{\prime} \mathrm{E}\right)$ was located in the southwest of Weberstedt, within the province of Thuringia, Germany, in the northeastern part of the Hainich National Park. The Hainich, with an area of 16000 ha, is the largest contiguous and most diverse broad-leaved forest of Germany and a part of it has been a UNESCO world natural heritage site since 2011. It has not been managed for forestry since 1990.

The mean annual temperature is $7.5^{\circ} \mathrm{C}$ and the mean annual precipitation is $670 \mathrm{~mm}$. The mean elevation of our site was $300 \mathrm{~m}$ a.s.l. The forest site had deciduous trees of diverse ages with a long-term forest history of at least $200 \mathrm{y}$ and grows on a Stagnic Luvisol (WRB 2006) developed from loess that is underlaid by Triassic limestone. 50 trees scattered within a maximum distance of $300 \mathrm{~m}$ from the center of the site were chosen for their height. The light intensity was approximately the same everywhere because the beech-dominated forest had a closed leaf cover. Nevertheless, slight differences in light intensity might have been possible due to different numbers of leaf layers.

\subsubsection{Experimental design and sampling setup}

\subsubsection{1 ${ }^{13} \mathrm{CO}_{2}$ pulse labeling}

Within a regeneration area of uniform light intensity under a closed beech canopy, 50 trees ( 25 beech, 25 ash) with approximately similar height (3-4 $\mathrm{m}$ ) were chosen scattered with a maximum distance of $300 \mathrm{~m}$ from the center of the site. Of these 50 trees 20 ashes (Fraxinus excelsior) and 20 beeches (Fagus sylvatica) were selected to perform a pulse labeling experiment, leaving 5 trees of each species as unlabeled reference trees. The aboveground biomass is listed in Table 2.1-1.

Table 2.1-1: Mean above biomass

\begin{tabular}{lcc}
$\begin{array}{l}\text { Tree } \\
\text { species }\end{array}$ & $\begin{array}{c}\text { Leaf Biomass }(\mathbf{g}) \\
\text { Mean +/- SD }\end{array}$ & $\begin{array}{c}\text { Stem Biomass }(\mathbf{g}) \\
\text { Mean +/- SD }\end{array}$ \\
\hline Beech & $71 \pm 5$ & $402.8 \pm 60.7$ \\
Ash & $45 \pm 3$ & $180 \pm 10$ \\
\hline
\end{tabular}

All leaves, stems and twigs were removed, tried and weighed. Labeling was performed on four or eight trees of each species on three consecutive days ( 8 trees on 16.08.2011 from 
11.30 to $13.30 ; 16$ trees on 17.08 .2011 from 9.30 to 12.30 and also 16 trees on 18.08.2011 from 9.30 to 11.30). The 20 trees of each species were considered as replicates, since the labeling was done on sunny days with similar light and microclimatic conditions (Table 2.1-2).

The ${ }^{13} \mathrm{C}$ was applied as ${ }^{13} \mathrm{CO}_{2}$ to the aboveground parts of the plants by simultaneously pulse labeling trees in individual chambers. The chambers were ca. $5 \mathrm{~m}$ high and $2.5 \mathrm{~m}$ in diameter consisting of transparent polyethylene film with a thickness of $80 \mu \mathrm{m}$ which were hung from a wooden frame and closed properly with adhesive tape to avoid gas leakage. The ${ }^{13} \mathrm{CO}_{2}$ pulse was produced by injecting $60 \mathrm{ml} 5 \mathrm{M}$ sulfuric acid $\left(\mathrm{H}_{2} \mathrm{SO}_{4}\right)$ into a solution of $100 \mathrm{ml}$ distilled water containing $6.85 \mathrm{~g}$ sodium carbonate $\left(\mathrm{Na}_{2} \mathrm{CO}_{3}\right)$ (Cambridge Isotope Laboratories, MA, USA) enriched to 99.0 atom\% ${ }^{13} \mathrm{C} .500 \mathrm{ml}$ polyethylene wide mouth bottles containing sodium carbonate were fixed to a bowl and placed inside the chamber. The chamber was then closed and sulfuric acid was carefully added from the outside into the $\mathrm{Na}_{2}{ }^{13} \mathrm{CO}_{3}$ solution using syringes, and the puncture holes caused by the syringes were sealed with tape. Sulfuric acid was added in fivefold excess to ensure complete evolution of ${ }^{13} \mathrm{CO}_{2}$. A 5-12 $\mathrm{V}$ fan inside each chamber guaranteed a uniform distribution of ${ }^{13} \mathrm{CO}_{2}$. Samples of $\mathrm{CO}_{2}$ inside the chambers at the beginning and end of the treatment were taken to determine the change in $\mathrm{CO}_{2}$ concentration.

\subsubsection{2 ${ }^{15} \mathrm{~N}$ labeling}

Prior to the $\mathrm{CO}_{2}$ pulse labeling, $12 \mathrm{ml}$ glass vials were used as reservoirs containing $9.7 \mathrm{ml}$ of a calcium nitrate solution. This ${ }^{15} \mathrm{~N}$ solution was made up of $36 \mathrm{~g}$ calcium nitrate (99.23 atom\% ${ }^{15} \mathrm{~N}$, Campro Scientific GMbH, Berlin, Germany) dissolved in $1200 \mathrm{ml}$ sterilized water. Three leaves of beech and three leaflets of ash with a similar area were cut 3 times on the edges to allow the uptake of the solution by the tree and then placed directly in the calcium nitrate solution in the vials. Three vials were fixed on the branches at different heights in each tree. The vials were closed with Parafilm and additionally covered with a transparent bag to avoid spilling on the ground. The vials were installed on the trees 3 days before the $\mathrm{CO}_{2}$ labeling and were removed before the $\mathrm{CO}_{2}$ labeling with a cut behind the leaves to avoid contamination of the ground or other leaves. Sampling was done after $4,8,13,23$, and 63 days. Leaf application of the ${ }^{15} \mathrm{~N}$ tracer was chosen because it allows the investigation of a unidirectional allocation belowground. 


\subsubsection{Sampling and isotope analysis}

Of the 20 labeled trees of each species, five sets of four trees along with one reference tree were selected randomly for sampling at five time intervals $(1,5,10,20$ and 60 days) after $\mathrm{CO}_{2}$ labeling (or 4, 8, 13, 23 and 63 days after ${ }^{15} \mathrm{~N}$ labeling). The plastic chamber was removed after the labeling period of $2 \mathrm{~h}$ and samples of four beeches and four ashes and a reference to each species were taken at each of the five time intervals.

All leaves of each tree were harvested completely, mixed after drying and subsampled. Stems were sampled $10 \mathrm{~cm}$ above the start of the root, in the middle of the tree and from the top part. Root samples were taken $15 \mathrm{~cm}$ from the main root after the tree was entirely uprooted to make sure it belongs to the labeled tree. Soil was sampled $15 \mathrm{~cm}$ from the tree with a split tube in three replicates. The intact core was divided into 3 depth intervals $(0-10 \mathrm{~cm} ; 10-20 \mathrm{~cm} ; 20-30 \mathrm{~cm})$ and all soil samples were sieved to $2 \mathrm{~mm}$. For the analysis of leaves, stem, root and bulk soil $\mathrm{C}$ and $\mathrm{N}$ content and $\delta^{13} \mathrm{C}$ and $\delta^{15} \mathrm{~N}$ values, all samples were freeze dried, ground in a ball mill (Retsch Schwingmühle MM2, Haan, Germany) and stored in a desiccator until further analysis.

Leaf and soil samples were filled into tin capsules for measurement of relative $\mathrm{N}$ and $\mathrm{C}$ isotope abundances using an elemental analyzer NA1500 (Fison-instruments, Rodano, Milano, Italy) coupled to a Delta plus isotope ratio mass spectrometer (Finnigan MAT, Bremen, Germany) through a ConFlo III interface (Thermo Electron Corporation, Bremen, Germany). $\delta^{13} \mathrm{C}$ and $\delta^{15} \mathrm{~N}$ values were calibrated based on co-measured certified IAEA Standards (IAEA-600, USGS26, USGS40, USGS41, IAEA-CH-6, IAEA-CH-7, NBS 18, IAEA-N-1, IAEA-N-2 and IAEA-NO-3).

\subsubsection{Calculation of ${ }^{15} \mathrm{~N}$ and ${ }^{13} \mathrm{C}$}

Plant uptake from sources of different isotope composition results in changes to their $\delta^{15} \mathrm{~N}$ and $\delta^{13} \mathrm{C}$ values and follows a two component mixing model according to Gearing (1991), as shown in equation (1),

$$
[C]_{\text {incTracer }}=[C]_{\text {component }} \cdot \frac{a t \%_{\text {labelled }}-a t \%_{\text {ref }}}{a t \%_{\text {appliedTraer }}-a t \%_{\text {ref }}}
$$

where $[\mathrm{C}]_{\text {component }}$ is the $\mathrm{C}$ content of the component ( $\mathrm{mmol} \cdot \mathrm{g}_{\text {dried soil/leaf;stem;root }}{ }^{-1}$ ) and $[\mathrm{C}]_{\text {incTracer }}$ is the total amount of ${ }^{15} \mathrm{~N}$ or ${ }^{13} \mathrm{C}$ incorporated into the plant in $\left(\mathrm{mmol} \cdot \mathrm{g}_{\text {dried }}\right.$ soil;leaf;stem;root ${ }^{-1}$ ), at\%labelled is the ${ }^{13} \mathrm{C}$ or ${ }^{15} \mathrm{~N}$ values of the labeled sample of the tree (leaf, stem, root, soil), at\% ref the ${ }^{13} \mathrm{C}$ or ${ }^{15} \mathrm{~N}$ values of the unlabeled reference sample of the tree 
(leaf, stem, root, soil), and at\%appliedTracer the ${ }^{13} \mathrm{C}$ enrichment of the added $\mathrm{CO}_{2}$ or, respectively, ${ }^{15} \mathrm{~N}$ enrichment of the added $\mathrm{Ca}\left({ }^{15} \mathrm{NO}_{3}\right)_{2}$.

\subsubsection{Microbial biomass analysis}

A portion of the $2 \mathrm{~mm}$ sieved soil was transferred into a plastic bag and stored at $5{ }^{\circ} \mathrm{C}$ for chloroform fumigation-extraction. For the determination of microbial $\mathrm{C}$ and $\mathrm{N}$ content and $\delta^{13} \mathrm{C}$ and $\delta^{15} \mathrm{~N}$ values, two subsamples of $15 \mathrm{~g}$ were taken. One of these was directly extracted and the other was fumigated with chloroform for 4 days in a desiccator, to be able to extract $\mathrm{C}$ and $\mathrm{N}$ from the lyzed microbial cells.

Both the fumigated and unfumigated samples were extracted with $45 \mathrm{ml}$ of $0.05 \mathrm{M} \mathrm{K}_{2} \mathrm{SO}_{4}$ and placed on a horizontal shaker for 1.5 hours. After shaking, the samples were centrifuged for $15 \mathrm{~min}$ at $3000 \mathrm{rpm}$, the supernatant was filtered (Rotilab® round cellulose filters, type 15A) and captured in $50 \mathrm{ml}$ plastic centrifuge tubes.

$\mathrm{C}$ and $\mathrm{N}$ content was measured on a TOC analyser multi $\mathrm{C} / \mathrm{N} \AA^{\circledR}$ (Analytik Jena, Jena, Germany). For $\delta^{13} \mathrm{C}$ measurements, the samples were freeze-dried and then measured on the same unit as the bulk soil samples.

${ }^{13} \mathrm{C}$ and ${ }^{15} \mathrm{~N}$ incorporation into fumigated and unfumigated extracts was calculated according to the mixing model in equation 1. Microbial biomass $\mathrm{C}$ and $\mathrm{N}$ was calculated as the difference between fumigated and unfumigated amount, ${ }^{13} \mathrm{C}$ and ${ }^{15} \mathrm{~N}$ uptake and corrected by an extraction coefficient of 0.45 for $\mathrm{C}(\mathrm{Wu}$ et al 1990) and 0.54 for $\mathrm{N}$ (Brookes et. al. 1985).

\subsubsection{Statistics}

Field replications were corrected for outliers using the Nalimov outlier test with significance levels of $95 \%$ (when four repetitions were available). An analysis of variance (ANOVA) was calculated to quantify how single variables contributed to the observed variances of the data. Tukey HSD tests for post hoc comparison were used to compare isotope enrichment or total ${ }^{13} \mathrm{C}$ or ${ }^{15} \mathrm{~N}$ uptake as dependent variables, while tree species, plant compartment and within-individual variation were used as independent variables (significance level of $p<0.05$ ). The error bars show a standard error of the mean (SEM) in all graphs. Linear Regression of the relative ${ }^{13} \mathrm{C}$ and ${ }^{15} \mathrm{~N}$ incorporation over time in soil (Figure 2.1-4) and microbial biomass (Figure 2.1-5) was fitted to the data according to a least square algorithm. 


\subsubsection{Results}

\subsubsection{1 ${ }^{13} \mathrm{C}$ and ${ }^{15} \mathrm{~N}$ dynamics aboveground}

At one day after labeling, beech had taken up $20.2 \%$ and ash $9.1 \%$ of the applied ${ }^{13} \mathrm{CO}_{2}$ in all measured compartments (Figure 2.1-1). The ${ }^{13} \mathrm{C}$ allocation has been calculated per gram dry weight, therefore these values are comparable despite differences in tree biomass (Table 2.1-1). Beech allocated significantly more ${ }^{13} \mathrm{C}$ to its leaves, stem and soil than ash. However, the roots did not differ in their ${ }^{13} \mathrm{C}$ allocation at day one after labeling (Figure 2.1-1). Leaves and stem were both highly enriched in ${ }^{13} \mathrm{C}$ (Figure 2.1-1) which reflects a rapid photosynthetic uptake in both trees but twice as much in beech than in ash. About $80 \%$ of the ${ }^{13} \mathrm{C}$ recovered in all compartments was located in the leaves at day one and about $20 \%$ in the stem, for both tree species. The ${ }^{13} \mathrm{C}$ signal was particularly pronounced for leaves and revealed a significant difference in dynamics between beech and ash. A rapid initial decrease in ${ }^{13} \mathrm{C}$ incorporation to values of about $20 \%$ of the initially incorporated ${ }^{13} \mathrm{CO}_{2}$ values was observed. However, beech showed this drop immediately and remained at the level of $20 \%$ from day 5 to day 60 , whereas ash reached this $20 \%$ mark by continued decrease until 20 days after labeling. The ${ }^{13} \mathrm{C}$ signal in the stem remained constant in beech and ash from day 1 until day 60 after labeling with the exception of a significant increase of the relative ${ }^{13} \mathrm{C}$ allocation at day 60 in beech (Figure 2.1-2 A). 


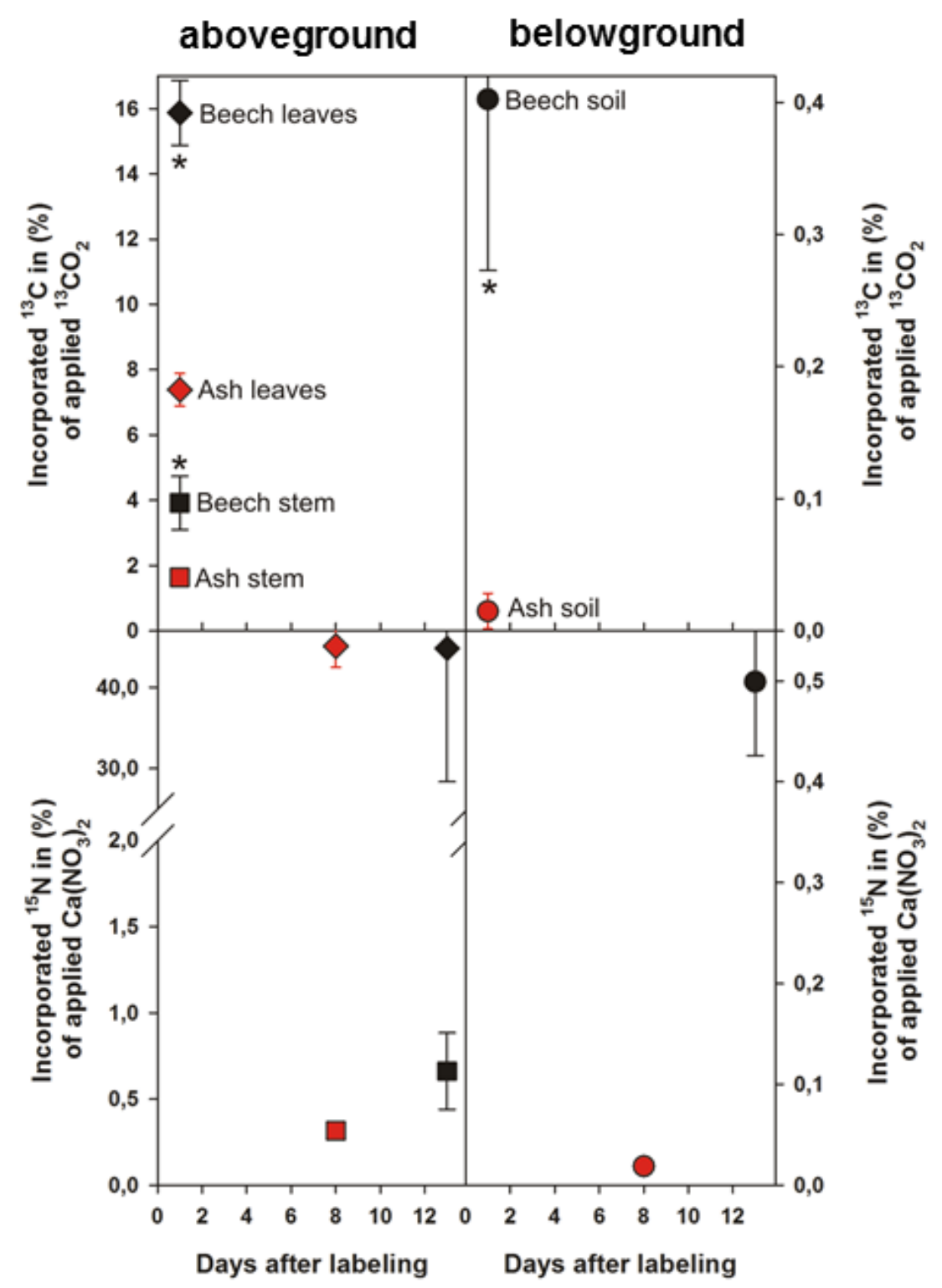

Figure 2.1-1: Upper panels: Total ${ }^{13} \mathrm{C}$ incorporation on day 1 in above- (left) and belowground (right) $C$ pools; Lower panel: Total ${ }^{15} \mathrm{~N}$ allocation of the maximal incorporated $\mathrm{Ca}\left(\mathrm{NO}_{3}\right)_{2}$ on day 13 for beech and day 8 for ash in above- (left) and belowground (right) $\mathrm{N}$ pools; in 0-30 cm depth and at a distance of $15 \mathrm{~cm}$ radius from the tree, beech (black symbols) and ash (red symbols). Error bars show SEM. * shows significant $(p<0.05)$ differences of the different compartments between ash and beech.

Whereas the highest total ${ }^{13} \mathrm{C}$ incorporation was always observed for day 1 , the highest ${ }^{15} \mathrm{~N}$ uptake from the applied $\mathrm{Ca}\left({ }^{15} \mathrm{NO}_{3}\right)_{2}$ into beech was recorded 13 days after removing the label solution, at $46.0 \%$. The highest ${ }^{15} \mathrm{~N}$ uptake from the applied $\mathrm{Ca}\left({ }^{15} \mathrm{NO}_{3}\right)_{2}$ into ash was detected 8 days after the labeling, at $45.4 \%$ (Figure 2.1-1). This time lag in ${ }^{15} \mathrm{~N}$ uptake 
might be due to the lack of measurement of twigs. The absolute allocation rates of the applied ${ }^{15} \mathrm{~N}$ differed neither in leaves nor in the stem between the tree species. $97.5 \%$ of the assimilated ${ }^{15} \mathrm{~N}$ was located in the leaves on day 13 in beech and $99.3 \%$ on day 8 in ash (Figure 2.1-2 C). For both trees, ${ }^{15} \mathrm{~N}$ in the leaves decreased thereafter. The first sampling at day 4 after the start of $\mathrm{N}$ labeling and the sampling at day 23 revealed that ash incorporated significantly more ${ }^{15} \mathrm{~N}$ into the stem $(0.5 \%$ of maximal incorporated $\mathrm{N})$ than beech $(0.05 \%$ of maximal incorporated $N)$. An immediate consistent increase of the relative ${ }^{15} \mathrm{~N}$ allocation into the stem in both trees over the entire experimental period could also be observed. However, the increase of the relative ${ }^{15} \mathrm{~N}$ allocation from leaves to stem over time in beech was more rapid than in ash. Beech had a relative ${ }^{15} \mathrm{~N}$ allocation of $5.4 \%$ on day 63 after the labeling in comparison to ash with 3.1\% (Figure 2.1-2 C).

In summary, in this experiment beech fixed twice as much ${ }^{13} \mathrm{C}$ by photosynthesis as ash, but both tree species incorporated a similar ${ }^{15} \mathrm{~N}$ amount into leaves. Beech showed a more rapid transport of photosynthates through the tree and allocated twice as much of the assimilated ${ }^{13} \mathrm{C}$ into the stem.

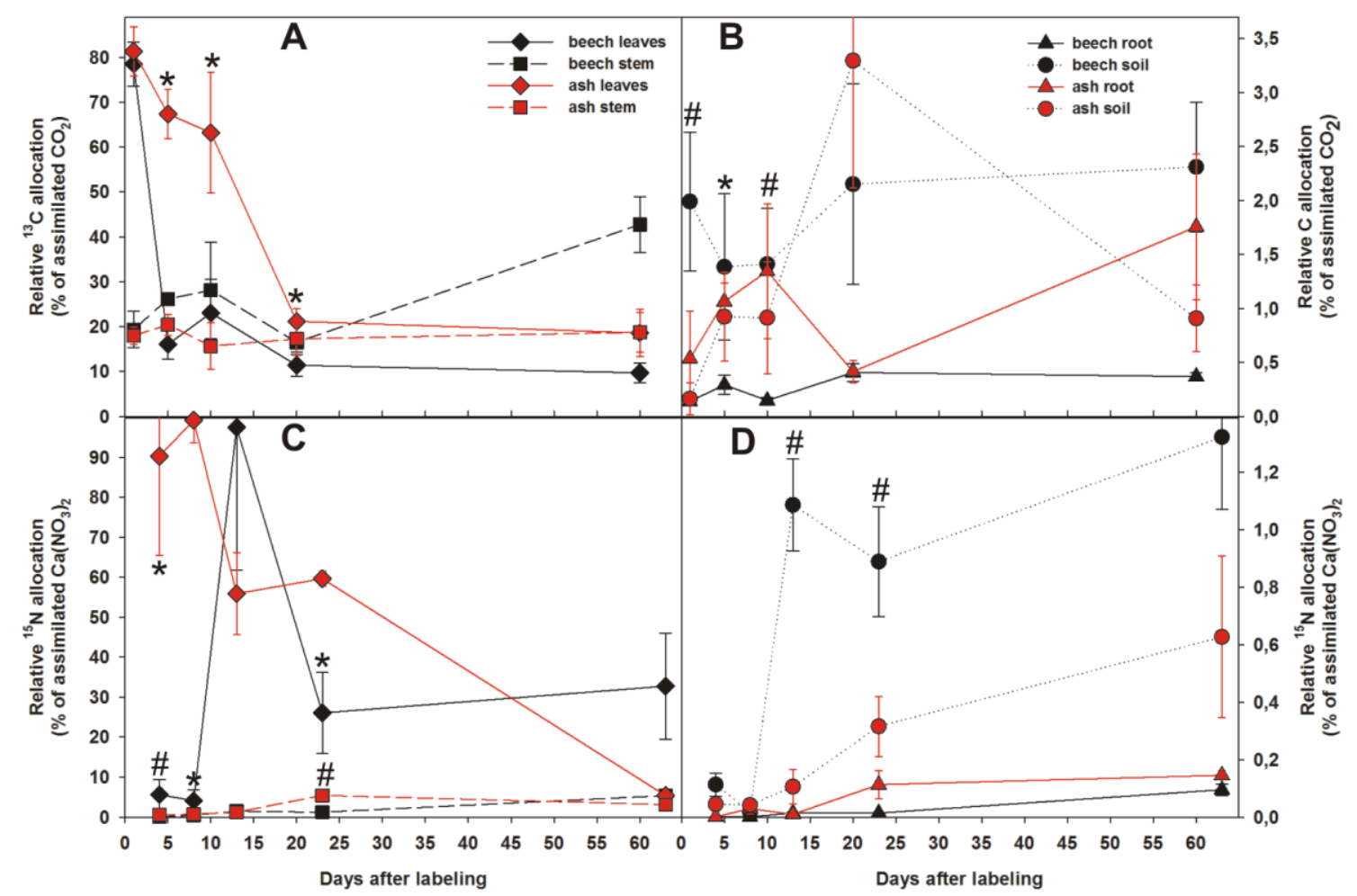

Figure 2.1-2: ${ }^{13} \mathrm{C}$ allocation (in \% of the initially assimilated ${ }^{13} \mathrm{CO}_{2}$ at day one) in (A) leaves (diamonds) and stem (squares), (B) roots (triangle) and soil (circles), 0-30 cm depth at a distance of $15 \mathrm{~cm}$ from the tree. Relative ${ }^{15} \mathrm{~N}$ allocation of the maximal incorporated $\mathrm{Ca}\left(\mathrm{NO}_{3}\right)_{2}$ (day 13 for beech and day 8 for ash) in (C) leaves and stem (D) roots and soil at $15 \mathrm{~cm}$ distance from tree at $0-30 \mathrm{~cm}$ depth in beech (black symbols) and ash (red 
symbols); Error bars show SEM; * shows significant $(p<0.05)$ differences of leaves and roots between beech and ash for individual sampling dates. \# shows significant $(p<0.05)$ differences of stem and soil between beech and ash for individual sampling dates.

\subsubsection{2 ${ }^{13} \mathrm{C}$ and ${ }^{15} \mathrm{~N}$ dynamics belowground}

A slight increase of relative ${ }^{13} \mathrm{C}$ incorporation observed over time in roots and soil was in accordance with the decrease in leaves and stem and reflects the belowground translocation of assimilated ${ }^{13} \mathrm{C}$ in both tree species (Figure $2.1-2 \mathrm{~A}, \mathrm{~B}$ ). The rapid ${ }^{13} \mathrm{C}$ transport in beech (Figure 2.1-2 B) showed that already at day one, beech released much more ${ }^{13} \mathrm{C}$ into the soil $\left(2.0 \%\right.$ of initially assimilated $\left.{ }^{13} \mathrm{C}\right)$ than ash $(0.2 \%$ of initially assimilated ${ }^{13} \mathrm{C}$ ). This can also be observed for all soil depths in the ${ }^{13} \mathrm{C}$ incorporation into microbial biomass (Figure 2.1-3 B). ${ }^{13} \mathrm{C}$ allocation in the microbial biomass had already peaked one day after labeling and showed a depth-related abundance in beech (Figure 2.1-3 B). Figure 2.1-3 (A) shows that ash displayed similar dynamics at all soil depths with a peak allocation of ${ }^{13} \mathrm{C}$ into the soil at day 20 , while beech had an initially higher and more constant rhizodeposition over the 60 days (Figure 2.1-3 A). On day five after labeling, ${ }^{13} \mathrm{C}$ allocation to the root was higher in ash than in beech (Figure 2.1-2 B). Most microbial biomass ${ }^{13} \mathrm{C}$ incorporation under ash was lower than the detection limit. Despite the fact that measurement accuracy is higher for microbial biomass than for soil (due to the high activity of microbial biomass in ${ }^{13} \mathrm{C}$ incorporation and a large passive $\mathrm{C}$ pool in soil), there was no significant enrichment of microbial biomass under ash. The low absolute ${ }^{13} \mathrm{C}$ assimilation of ash accounts for the low enrichments in microbial biomass, and there were no differences to the unlabeled reference. 


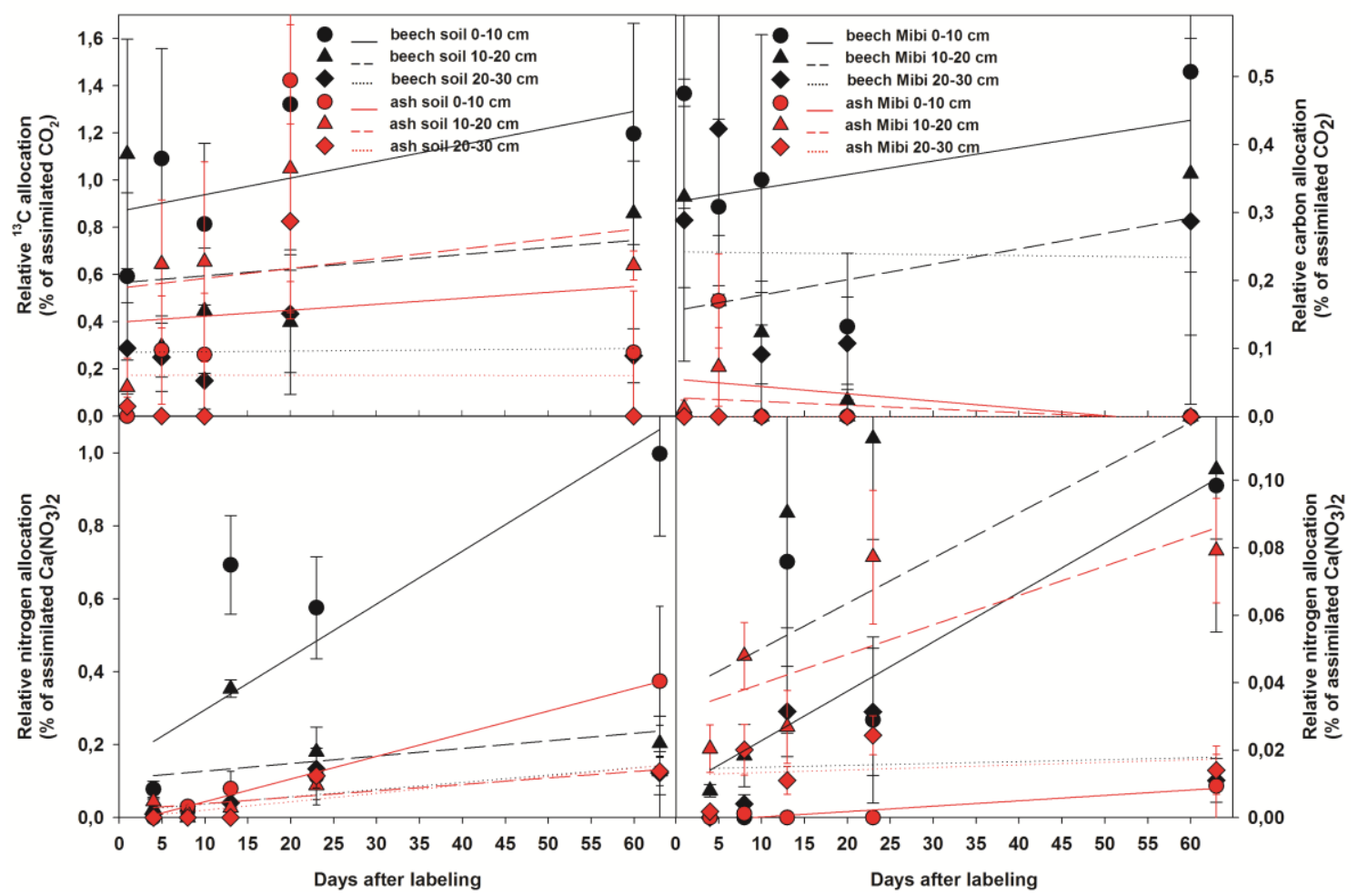

Figure 2.1-3: Relative ${ }^{13} \mathrm{C}$ allocation (\% of the initially assimilated ${ }^{13} \mathrm{CO}_{2}$ at day one) in $(A)$ soil at 0-10 cm depth (circle), $10-20 \mathrm{~cm}$ depth (triangles), 20-30 cm depth (diamonds) and (B) microbial biomass depending on depth and time at $15 \mathrm{~cm}$ distance from the tree and in beech (black symbols) and ash (red symbols). Relative ${ }^{15} \mathrm{~N}$ allocation of the maximal incorporated $\mathrm{Ca}\left(\mathrm{NO}_{3}\right)_{2}$ (day 13 for beech and day 8 for ash) in (C) soil and (D) microbial biomass depending on depth and time. Error bars show SEM; * shows significant ( $p<$ 0.05) differences between beech and ash at one depth of 0-10 cm, \# at a depth of 10-20 cm; small letters show differences between depths in one tree species: (a) shows significant $(p<0.05)$ differences between beech soil at a depth of $0-10 \mathrm{~cm}$ to both other depths for individual sampling dates (b) shows differences between ash soil at a depth of 10-20 cm to both other depths for individual sampling dates.

13 days after the $\mathrm{N}$ labeling a significant difference in the ${ }^{15} \mathrm{~N}$ signal was measured in the soil sampled at $15 \mathrm{~cm}$ distance from beech $\left(0.1 \%\right.$ of the maximal incorporated $\left.{ }^{15} \mathrm{~N}\right)$ and ash $\left(0.04 \%\right.$ of the maximal incorporated ${ }^{15} \mathrm{~N}$ ) (Figure 2.1-2 D). Beech allocated more of the incorporated ${ }^{15} \mathrm{~N}$ to soil but less ${ }^{15} \mathrm{~N}$ to its roots - a behavior which is similar to the ${ }^{13} \mathrm{C}$ partitioning between soil and roots (Figure 2.1-2 B). Beech also displayed a significantly depth-related rhizodeposition with a maximum in the $0-10 \mathrm{~cm}$ soil segment starting at day 13 after labeling (Figure 2.1-3 C). The rapid transport of assimilates in beech is also noticeable in the $\mathrm{N}$ allocation. While the ${ }^{15} \mathrm{~N}$ signal is evident in the soil of beech at day 13 , 
it takes until day 65 to show a pronounced signal in ash soil. This peak on day 13 for beech is also reflected in the $\mathrm{N}$ allocation to the microbial biomass. Beech allocated only one tenth of its incorporated ${ }^{15} \mathrm{~N}$ to the microbial biomass, whereas for ash almost all was taken up into microbial biomass. ${ }^{15} \mathrm{~N}$ incorporation into microbial biomass was significantly higher in soil of 10-20 cm depth under ash than at other depths for ash and the same depth for beech (Figure 2.1-3 D).

In summary, beech has an initially higher and more constant rhizodeposition than ash and beech also displays a higher ${ }^{13} \mathrm{C}$ uptake by microbial biomass than ash. However, ash provides almost all of its exudated ${ }^{15} \mathrm{~N}$ for uptake into microbial biomass in comparison to beech. Only $10 \%$ of the exudated ${ }^{15} \mathrm{~N}$ was taken up by microorganisms under beech.

\subsubsection{Spatial gradients of ${ }^{15} \mathrm{~N}$ and ${ }^{13} \mathrm{C}$ allocation around the trees}

The allocation of ${ }^{13} \mathrm{C}$ at increasing distances from the tree was investigated at day 5 after ${ }^{13} \mathrm{C}$ labeling (day 8 after the start of ${ }^{15} \mathrm{~N}$ labeling). At any given soil depth there was no change in ${ }^{15} \mathrm{~N}$ or ${ }^{13} \mathrm{C}$ exudation along the investigated $60 \mathrm{~cm}$ distance. However, there were differences between the soil depths, with ash allocating significantly more ${ }^{13} \mathrm{C}$ to the $10-20 \mathrm{~cm}$ depth than to any other depth throughout the $60 \mathrm{~cm}$ distance from the tree (Figure 2.1-4). For beech, ${ }^{13} \mathrm{C}$ and ${ }^{15} \mathrm{~N}$ enrichment was always highest in the top $10 \mathrm{~cm}$ compared to the other soil depths. However, due to the large $C$ pools in these forest soils, the ${ }^{13} \mathrm{C}$ enrichment was too low to draw conclusions on the $20-30 \mathrm{~cm}$ depth for either tree species or to see any clear effects of increasing distance from the trees. 


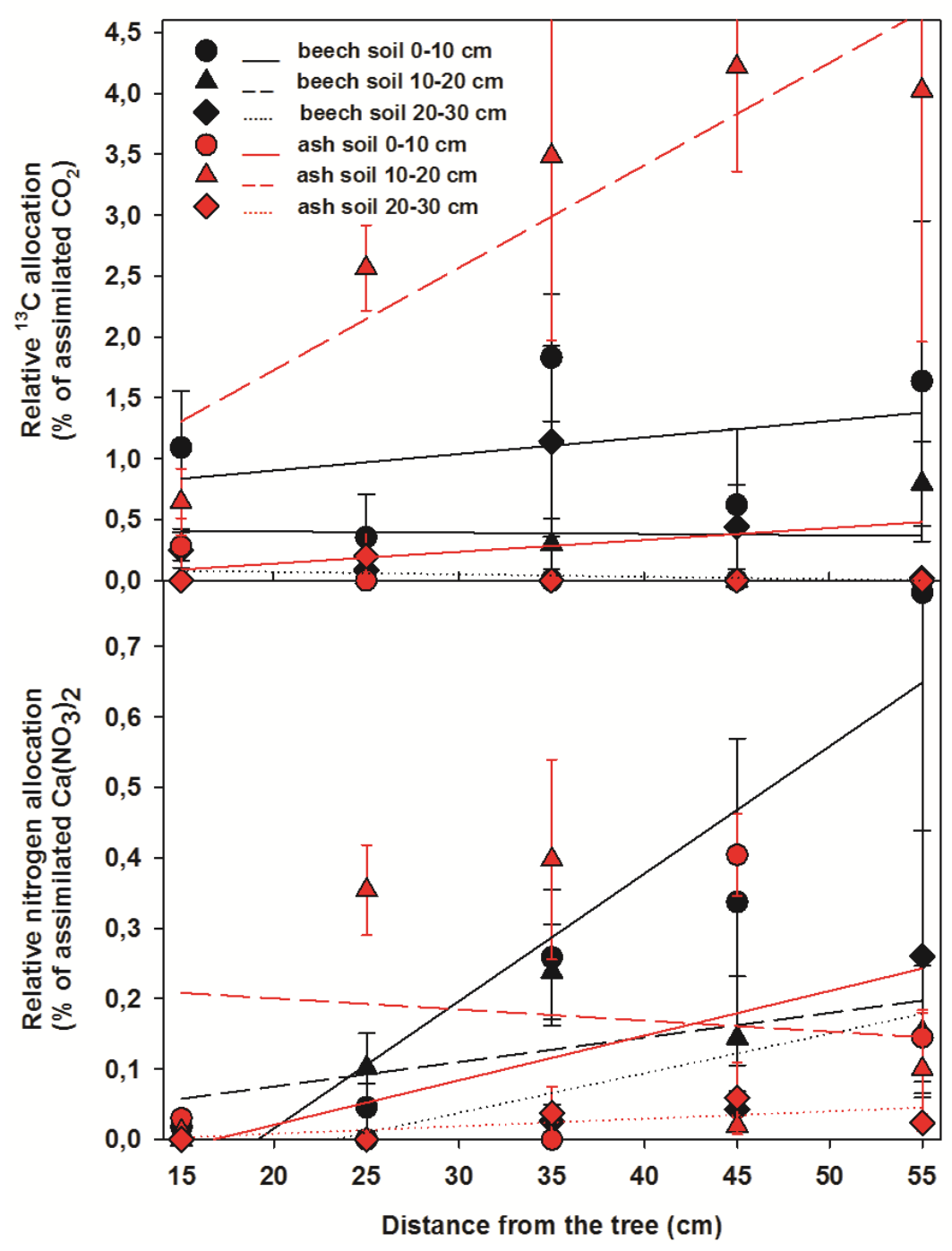

Figure 2.1-4: Relative ${ }^{13} \mathrm{C}$ allocation (in \% of the initially assimilated ${ }^{13} \mathrm{CO}_{2}$ ) with linear fits in soil at 0-10 cm depth (circle/solid line), 10-20 cm depth (triangles/long dash line), 20-30 $\mathrm{cm}$ depth (diamonds/dotted lines) and distance from the tree at day 5 after labeling and in beech (black symbols/lines) and ash (red symbols/lines). For parameters of the linear regressions see Table 2.1-3. Relative $N$ allocation of the maximal incorporated ${ }^{15} \mathrm{~N}$ (day 13 for beech and day 8 for ash) with linear fits in soil depending on depth and distance from the tree. Error bars show SEM.

For both tree species, the ${ }^{13} \mathrm{C}$ allocation to soil displayed a positive trend with increasing distance from the tree, related to the increase of the rooted soil volume with distance. For both tree species, the highest ${ }^{13} \mathrm{C}$ and ${ }^{15} \mathrm{~N}$ incorporation into the microbial biomass was found in the top $10 \mathrm{~cm}$ (Figure 2.1-5). Thus, spatial allocation to microbial biomass does not reflect the distribution of allocation to soil, which might be connected with root distribution or might indicate that the amount of $\mathrm{C}$ input is not controlling microbial ${ }^{13} \mathrm{C}$ 
incorporation. The distance effect is less pronounced in the ${ }^{15} \mathrm{~N}$ allocation in both tree species (Figure 2.1-4; Figure 2.1-5).

In summary, a depth-related rhizodeposition ${ }^{13} \mathrm{C}$ and ${ }^{15} \mathrm{~N}$ was evident under beech. Ash allocated more ${ }^{13} \mathrm{C}$ to the $10-20 \mathrm{~cm}$ soil depth. And at any given soil depth there was no change in ${ }^{15} \mathrm{~N}$ or ${ }^{13} \mathrm{C}$ exudation along the investigated $60 \mathrm{~cm}$ distance.

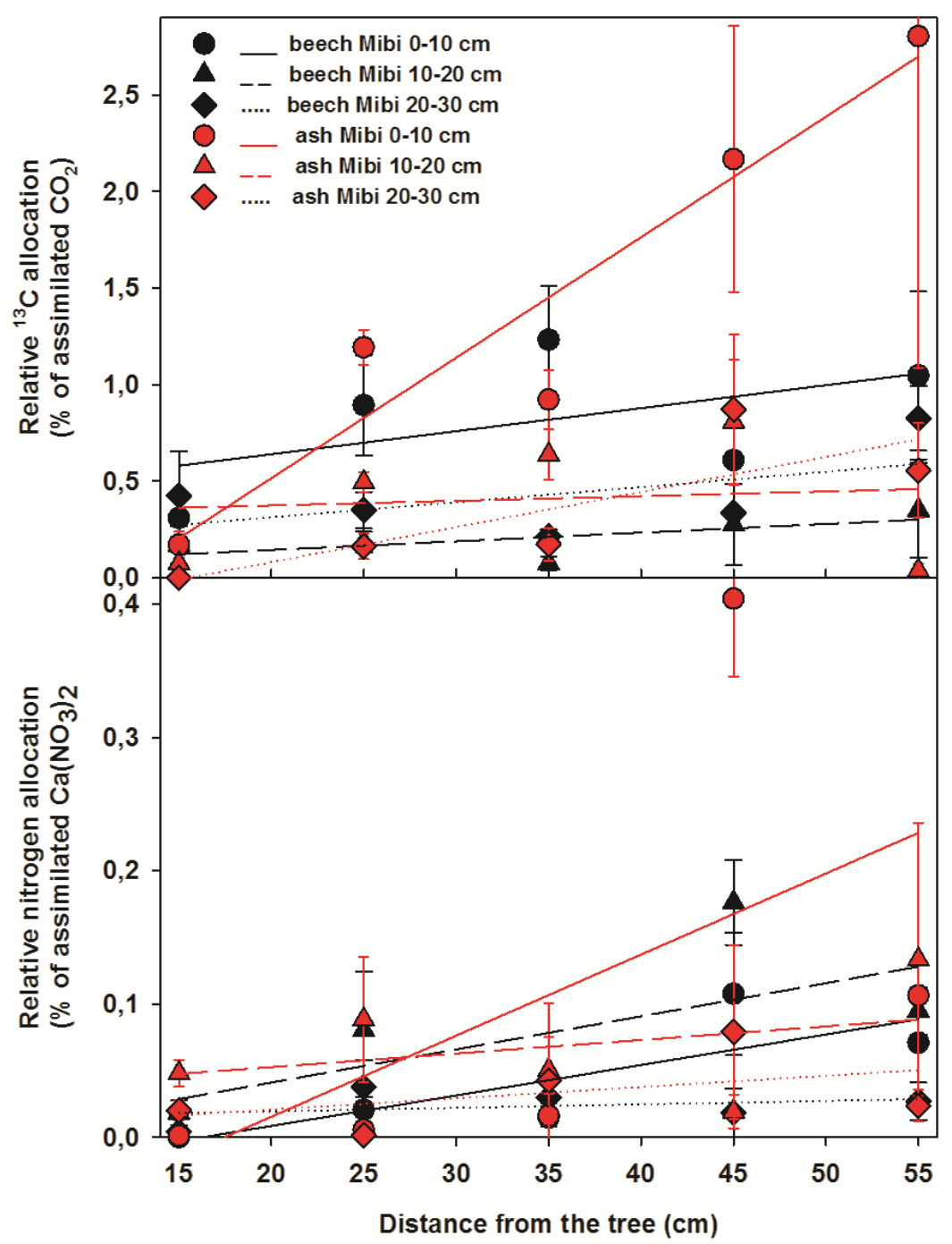

Figure 2.1-5: Relative ${ }^{13} \mathrm{C}$ allocation (in \% of the initially assimilated 13CO2) with linear fits in microbial biomass at 0-10 cm depth (circle/solid line), $10-20 \mathrm{~cm}$ depth (triangles/long dash line), 20-30 cm depth (diamonds/dotted lines) depending on depth and distance from the tree at day 5 after labeling and in beech (black symbols/lines) and ash (red symbols/lines). For parameters of the linear regressions see Table 2.1-3. Relative $N$ allocation of the maximal incorporated ${ }^{15} \mathrm{~N}$ (day 13 for beech and day 8 for ash) with linear fits in microbial biomass depending on depth and distance from the tree. Error bars show SEM. 


\subsubsection{Discussion}

\subsubsection{C allocation within plant-soil system depending on tree species}

Given the major importance of belowground $\mathrm{C}$ and $\mathrm{N}$ allocation for soil processes, we used a quantitative method for investigating the coupling of canopy $C$ assimilation with belowground processes. Therefore, we were able to trace directly the $\mathrm{C}$ fluxes into the soil by two tree species. This study revealed that beech assimilated twice as much of the applied ${ }^{13} \mathrm{CO}_{2}$ as ash, but beech and ash incorporated similar ${ }^{15} \mathrm{~N}$ amounts into leaves. The photosynthates were transported belowground through phloem more rapidly in beech than in ash and ash preferentially accumulated ${ }^{15} \mathrm{~N}$ and ${ }^{13} \mathrm{C}$ in the roots. However, beech released more ${ }^{13} \mathrm{C}$ and ${ }^{15} \mathrm{~N}$ via rhizodeposition into the soil than ash, which was also subsequently recovered in microbial biomass. This approach enables tracing of aboveand belowground $\mathrm{C}$ and $\mathrm{N}$ allocation and consequently can reveal the controlling influence of individual tree species on broad leaf forest $\mathrm{C}$ and $\mathrm{N}$ cycles. Pulse-labelling of trees with ${ }^{13} \mathrm{CO}_{2}$ and ${ }^{15} \mathrm{~N}$ allows quantification of at least three important aspects of whole-plant $\mathrm{C}$ and $\mathrm{N}$ metabolism: 1) the portion of assimilated $\mathrm{C}$ and incorporated $\mathrm{N}, 2$ ) the rate of transfer of $\mathrm{C}$ and $\mathrm{N}$ between compartments, 3) the residence time of $\mathrm{C}$ and $\mathrm{N}$ in these compartments. Only a few in-situ labelling experiments on tall trees have been reported (Carbone et al., 2007; Högberg et al., 2008; Andersen et al., 2010; Keel et al., 2012; Shibistova et al., 2012) and even fewer experiments have provided quantitative insights into $C$ residence times in short-lived storage pools and of transfer rates among plant compartments and between plants, soil and the atmosphere (Plain et al., 2009; Epron et al., 2011; Warren et al., 2012). The many differences between individual tree species cause tremendous challenges in tree labeling studies - especially if focused on timeseries allocation patterns. The necessity to harvest the entire tree to receive a full isotopic budget means that over time series not only other time points but also other tree individuals have to be compared. This introduces high variability to the data, as can be seen in Figure 2 und 3. Nevertheless, such tree labeling studies in the field offer unique opportunities to trace $\mathrm{C}$ and $\mathrm{N}$ allocation patterns under natural conditions.

The transfer time of photosynthates to ecosystem respiration has been indirectly estimated by tracing natural ${ }^{13} \mathrm{C}$ fluctuations related to climate-induced variations in ${ }^{13} \mathrm{C}$ discrimination during photosynthesis. Time lags were observed for tall Douglas fir trees (Bowling et al., 2002; McDowell et al., 2004), mixed hardwood forest (Mortazavi et al., 2005) and beech and oak (Epron et al., 2012). Epron et al. (2012) came to the conclusion that the relationship between the rate of $\mathrm{C}$ transfer and the time lag of peak ${ }^{13} \mathrm{CO}_{2}$ efflux from the soil differs between broad-leaved species (oak and beech) and pine. Dannoura 
et al. (2011) and Wingate et al. (2010) stated that the distinctly different transfer time of ${ }^{13} \mathrm{C}$ belowground between two broad-leaved species and pine is caused by differences in the velocity of photosynthate transport via the phloem sap. In our study, we just compared two broad-leaved species and a rapid photosynthetic uptake in beech was detected, but also a species-specific time lag between beech and ash in the ${ }^{13} \mathrm{C}$ allocation belowground. The higher photosynthetic ${ }^{13} \mathrm{CO}_{2}$ fixation can be partially attributed to the higher leaf biomass $(p<0.01)$ and thus photosynthetically active tissue in beech than in ash. However, the leaf area, not measured in this study, may be an even more accurate physiological tree parameter to characterize photosynthetic capability. Nevertheless, it can be stated that the $\mathrm{CO}_{2}$ fixation capacity of beech is significantly higher than of ash trees of similar tree height. Tree size and age may also affect $\mathrm{CO}_{2}$ uptake and distribution. However, in this study we could unfortunately not repeat the measurements on the trees of different sizes, although that would be an interesting approach for further studies.

Already at day one after labeling the relative ${ }^{13} \mathrm{C}$ allocation of the assimilated $\mathrm{CO}_{2}$ was about $80 \%$ in the leaves and about $20 \%$ in the stem in both tree species. Beech and ash transported about $75 \%$ of the initially incorporated $\mathrm{C}$ away from the leaves which resulted in the clear peak of ${ }^{13} \mathrm{C}$ allocation in the stem of beech. Ash showed a slower decrease of $\mathrm{C}$ in the leaves and just a slight increase in the stem which might be explained by leaf respiration of most of the assimilated $\mathrm{C}$. Thus, there was no time lag difference detectable in the uptake of the ${ }^{13} \mathrm{C}$ between the two tree species, but there was already a difference in time lag noticeable in the allocation into the stem. However, there might also be a difference in the velocity of photosynthate transport via the phloem sap, which causes the time lag of the $C$ transport observed for ash and beech.

Ryan et al. (1996) showed that the dark respiration from foliage and fine roots at night was linearly related to biomass and $\mathrm{N}$ content, but $\mathrm{N}$ was a better predictor of $\mathrm{CO}_{2}$ efflux than plant biomass. They concluded that the higher the $\mathrm{N}$ content, the greater the $\mathrm{CO}_{2}$ efflux produced. Langenbruch et al. (2012) showed in the same forest that ash litter has a higher $\mathrm{N}$ content than beech, which would support our findings for dark respiration with regard to the results of Ryan et.al (1996). Therefore, our study leads to the conclusion that ash respires most of the assimilated $C$ directly in the leaves - presumably at night, whereas beech allocates more of the assimilated $\mathrm{C}$ belowground.

Trees like beech accumulate more $\mathrm{C}_{\text {org }}$ in the forest floor and less $\mathrm{C}_{\text {org }}$ in the mineral soil compared to ash (Langenbruch et al., 2012). This property of beech was mainly attributed to the high C:N and lignin: $\mathrm{N}$ ratio in litter, which slows decomposition (Guckland et al., 2009b; Kooijman and Cammeraat, 2010). However Vesterdal et al. (2008) showed that the forest floor and litter fall $\mathrm{C}: \mathrm{N}$ ratios were not related, whereas the $\mathrm{C}: \mathrm{N}$ ratio of mineral 
soil $(0-30 \mathrm{~cm})$ better indicated $\mathrm{N}$ status of the tree under beech and ash on rich soil. They already suggested that European deciduous tree species differ in $\mathrm{C}$ and $\mathrm{N}$ sequestration rates within forest floor and mineral soil. However, Callesen et.al. (2015) stated recently that the average forest SOC stock remains unchanged over decades for soils $<4.1 \% \mathrm{C}$ in the top mineral soil, whereas the sink/source status of very $\mathrm{C}$ rich and organic soils remains uncertain. Thus, besides the slow litter decomposition under beech, rhizodeposition could be another reason explaining the higher $\mathrm{C}$ accumulation. Nevertheless, Meinen et al. (2009) and Cesarz et al. (2013) showed that ash has more fine roots and a more vigorous root growth than beech, which should also lead to more rhizodeposition. Ash also preferentially invested the assimilated ${ }^{13} \mathrm{C}$ into the root biomass in our study. Already five days after the labeling, the relative ${ }^{13} \mathrm{C}$ allocation into the root of ash was significantly higher than in beech. However, our experiment also revealed rapid ${ }^{13} \mathrm{C}$ transport through the beech tree, and also significantly higher ${ }^{13} \mathrm{C}$ allocation via the roots into the soil in beech. At day one after labeling, beech had already allocated $2 \%$ of the assimilated ${ }^{13} \mathrm{CO}_{2}$ into the soil. This is 10 times more $\mathrm{C}$ than observed for ash. Beech also showed an initially higher and more constant rhizodeposition over the 60 days than ash. These findings demonstrate that the ${ }^{13} \mathrm{CO}_{2}$ labeling technique applied in our experiment is suitable to investigate $C$ rhizodeposition into soil under tall trees in deciduous forests in situ.

Comparison of various ecosystems revealed that the relative belowground translocation of assimilated $\mathrm{C}$ for trees is smaller than, for example, for grasses (Kuzyakov and Domanski, 2000). Our results demonstrate clearly that there is a species effect in the rhizodeposition even if two deciduous tree species are compared. This finding has to be considered in further labeling experiments. Only a small proportion of the rhizodeposits remain in the soil because most of the $\mathrm{C}$ rhizodeposits are decomposed to $\mathrm{CO}_{2}$ by microorganisms (Kuzyakov and Larionova, 2006; Werth et al., 2006; Jones et al., 2009). Microbial biomass is composed of a large number of various microorganisms and includes the extraradical mycelium of mycorrhizal fungi. A rapid transfer of photosynthate to ectomycorrhiza has indeed been reported (Leake et al., 2001; Esperschütz et al., 2009; Hogberg et al., 2010) . The results in our experiment corroborate those findings. Beech is associated with ectomycorrhiza and ash roots with arbuscular mycorrhiza (Meinen et al., 2009). For beech, ${ }^{13} \mathrm{C}$ allocation into the microbial biomass peaked already at day one after the labeling and showed a depth-related abundance. This can be explained by the fast transfer of $\mathrm{C}$ from roots to mycorrhizal fungi in beech.

We conclude that ${ }^{13} \mathrm{C}$ labelling of trees offers the unique opportunity to trace the fate of labelled $\mathrm{CO}_{2}$ into the tree and its release to the soil and the atmosphere in forests in situ. Thus, pulse labelling enables the quantification of $C$ partitioning in forests and the 
assessment of the role of $\mathrm{C}$ and $\mathrm{N}$ partitioning for growth of individual tree compartments, resource acquisition and $C$ sequestration in soils dependent on season and tree growth stage (Epron et al., 2012).

\subsubsection{N allocation within plant-soil system depending on tree species}

To investigate the partitioning of $\mathrm{N}$ among soil, litter, below- and above-ground biomass, ${ }^{15} \mathrm{~N}$-nitrate $\left({ }^{15} \mathrm{NO}_{3}{ }^{-}\right)$as well as ${ }^{15} \mathrm{~N}$-ammonium $\left({ }^{15} \mathrm{NH}_{4}{ }^{+}\right)$has been added to the soil in predominantly coniferous forest ecosystems (Preston and Mead, 1994; Buchmann et al., 1995; Tietema et al., 1998; Perakis and Hedin, 2001; Compton and Boone, 2002). The results from those studies showed that inorganic $\mathrm{N}$ allows a rapid and localized investigation of the $\mathrm{N}$ partitioning between plants and microorganisms from soil (Kuzyakov and $\mathrm{Xu}, 2013)$. In this experiment, $\mathrm{N}$ tracer was added to leaves, in contrast to the other studies.

The highest ${ }^{15} \mathrm{~N}$ uptake from the applied $\mathrm{Ca}\left({ }^{15} \mathrm{NO}_{3}\right)_{2}$ was observed 13 days after the start of the $\mathrm{N}$ labeling from beech trees, at $46.0 \%$ (Figure 2.1-1). For ash the relative incorporation was similar, but this maximum occurred earlier, i.e. 8 days after the labeling. Thus, almost half of the applied ${ }^{15} \mathrm{~N}$ could be recovered in the trees. However, the delay in the ${ }^{15} \mathrm{~N}$ incorporation maximum was unexpected as the highest total ${ }^{13} \mathrm{C}$ recovery was observed for day one after labelling in both tree species. This delay in the maximum of $\mathrm{N}$ recovery might be due to the labeling of a limited number of leaves, leading to $\mathrm{N}$ allocation from the labelled leaves through twigs to other leaves. However, our results revealed that the $\mathrm{N}$ redistribution in the beech crown proceeds faster than in ash.

Fine roots of ash are almost absent in some parts of the soil profile but are clustered in other parts, forming hot spots within the profiles (Schütt et al., 2006; Pausch and Kuzyakov, 2011). Beech in contrast has a heart root system in which several major roots are developed, growing in parallel into the depth (Schütt et al., 2006). These differences in root distribution within the pedon can account for the depth-related ${ }^{15} \mathrm{~N}$ rhizodeposition of beech with a maximum in the topsoil, whereas ash, with lower absolute ${ }^{15} \mathrm{~N}$ allocation into soil, showed a more homogenous ${ }^{15} \mathrm{~N}$ distribution in our study. The fact that roots in different soil depths show altered physiological activities might be the reason for ash displaying significantly higher ${ }^{15} \mathrm{~N}$ incorporation in the microbial biomass in $10-20 \mathrm{~cm}$ in comparison to the topsoil and to beech at the same depth. ${ }^{15} \mathrm{~N}$ of the ash allocated to the soil was almost completely incorporated into the microbial biomass. In contrast, for beech only one tenth of its $\mathrm{N}$ was allocated to microbial biomass. This indicates that ash $\mathrm{N}$ exudates are more microbially available, presumably in the form of $\mathrm{N}$-rich, low-molecular weight root exudates like amino acids. In contrast, such monomeric substances may only 
make up a small proportion of the $\mathrm{N}$ released by beech: Beech rhizodeposition may be dominated not by root exudates but by more stable structural compounds like proteins.

Another explanation for the contrasting ${ }^{15} \mathrm{~N}$ distribution between ash and beech in soil and microbial biomass could be the types of mycorrhiza the tree species associate with. Beech is associated with ectomycorrhiza and ash roots with arbuscular mycorrhiza (Meinen et al., 2009). The type of mycorrhizal association may also affect root activity. Meinen et al. (2009) showed by microscopic inspection of beech and ash that the mycorrhizal colonization rate was significantly higher in beech than in ash roots (Cesarz et al., 2013). This may account for the higher ${ }^{15} \mathrm{~N}$ allocation into soil and microbial biomass in beech in our experiment.

Ash has more fine roots with a more vigorous root growth than beech and in general fine roots tend to contain more N (Meinen et al., 2009; Cesarz et al., 2013). Our study showed that ash incorporated more ${ }^{15} \mathrm{~N}$ into roots and had less rhizodeposition into the soil, which can be explained by the morphology of the ash root system. The results suggest that beech and ash differentially impact soil processes: Ash preferentially invests allocated $\mathrm{C}$ and $\mathrm{N}$ in root biomass formation whereas beech affects the belowground system via root exudates and associated changes in rhizosphere microorganisms and $\mathrm{C}$ dynamics. Therefore, the individual strategies of $\mathrm{C}$ and $\mathrm{N}$ allocation of beech and ash are representative examples of niche strategies of two broad-leaved trees in deciduous forests. Although we cannot conclude which distinct advantages beech and ash achieve from their individual niche strategies, our results suggest that differences in $\mathrm{C}$ and $\mathrm{N}$ allocation patterns between ash and beech provide a higher diversity of soil functions. Especially in species-poor systems like broad-leaved forest, tree diversity will increase functional diversity in soils and thus improve ecosystem stability compared to forests with pure stands of a single tree species. 


\subsubsection{Conclusions}

Tree species effects on $\mathrm{C}$ and $\mathrm{N}$ allocation and dynamics above- and belowground were investigated for beech and ash. Beech assimilates more $\mathrm{CO}_{2}$ than ash trees of similar size, presumably due to a higher amount of photosynthetically active leaf biomass. Ash stores more $\mathrm{C}$ and $\mathrm{N}$ in the plant biomass, at least in August. Beech had a faster belowground transfer of photosynthate including a faster release of $C$ in root exudates to microorganisms feeding on rhizodeposition. A lower and slower $C$ transfer belowground by ash compared to beech was discovered and all $C$ released by ash into soils was recovered in microbial biomass.

The labeling with $\mathrm{Ca}\left({ }^{15} \mathrm{NO}_{3}\right)_{2}$ clearly revealed different $\mathrm{N}$ allocation patterns for beech and ash: Whereas ash allocated $0.2 \%$ of the maximal incorporated ${ }^{15} \mathrm{~N}$ belowground mainly for root growth after 63 days, beech distributed only $0.1 \%$ of the maximal incorporated ${ }^{15} \mathrm{~N}$ into the root. Nevertheless, of the ${ }^{15} \mathrm{~N}$ allocated belowground, beech allocated the greater proportion to the soil ( $1.3 \%$ of the total ${ }^{15} \mathrm{~N}$ recovery) while only $0.6 \%$ were released by ash after 63 days. However, no methods currently exist to differentiate between direct translocation from root to mycorrhizal hypha and exudation and microbial uptake from soil solution.

Furthermore, for other tree species dominant in various forest ecosystems, the composition of root exudates and the fate of $C$ in the soil microbial community need to be investigated to be able to understand $\mathrm{C}$ and $\mathrm{N}$ cycles. This knowledge is essential to 1) assess the ability of forest ecosystems to sequester $C$ above- and belowground and 2) to improve conservation projects in deciduous forest systems and estimate their influence on the global C cycle. 


\subsubsection{Acknowledgements}

We wish to thank Sarah Zieger, Ronny Thoms and Michaela Rath (University of Göttingen) for their contribution to the field experiment and Kay Schünke and Steffen Wolf for helping in the field and also the KOSI for their continuous support with the isotope analyses and the Hainich National Park for the work permission. I am also very grateful to my student assistants Anika Handke and Anna Meyer and the technical staff, especially Ingrid Ostermeyer and Susann Enzmann, of the Soil Science of Temperate Ecosystems for their help in laboratory as well as to Maire Holz, who conducted a Bachelor thesis in this project. Financial support for this work was provided by German Research Foundation (DFG). This investigation contributes to the project B5 of the Graduiertenkolleg 1086. 


\subsubsection{References}

Andersen, C. P., Ritter, W., Gregg, J., Matyssek, R., Grams, T. E. E. (2010): Below-ground carbon allocation in mature beech and spruce trees following long-term, experimentally enhanced $\mathrm{O}_{3}$ exposure in Southern Germany. Environmental Pollution 158, 2604-2609.

Augusto, L., Ranger, J., Binkley, D.,Rothe, A. (2002): Impact of several common tree species of European temperate forests on soil fertility. Annals of Forest Science 59, 233-253.

Bauhus, J., Pare, D.,Cote, L. (1998): Effects of tree species, stand age and soil type on soil microbial biomass and its activity in a southern boreal forest. Soil Biology \& Biochemistry 30, 1077-1089.

Berger, T. W., Inselsbacher, E., Mutsch, F.,Pfeffer, M. (2009a): Nutrient cycling and soil leaching in eighteen pure and mixed stands of beech (Fagus sylvatica) and spruce (Picea abies). Forest Ecology and Management 258, 2578-2592.

Berger, T. W., Untersteiner, H., Toplitzer, M.,Neubauer, C. (2009b): Nutrient fluxes in pure and mixed stands of spruce (Picea abies) and beech (Fagus sylvatica). Plant and Soil 322, 317-342.

Bowling, D. R., McDowell, N. G., Bond, B. J., Law, B. E.,Ehleringer, J. R. (2002): ${ }^{13} \mathrm{C}$ content of ecosystem respiration is linked to precipitation and vapor pressure deficit. Oecologia 131, 113-124.

Buchmann, N., Schulze, E. D., Gebauer, G. (1995): ${ }^{15} \mathrm{~N}$ ammonium and ${ }^{15} \mathrm{~N}$ nitrate uptake of a 15-year-old Picea abies plantation. Oecologia 102, 361-370.

Callesen, I., Nilsson, L. O., Schmidt, I. K., Vesterdal, L., Ambus, P., Christiansen, J. R., Högberg, P., Gundersen, P. (2013): The natural abundance of ${ }^{15} \mathrm{~N}$ in litter and soil profiles under six temperate tree species: $\mathrm{N}$ cycling traits depend on tree species and site fertility. Plant and Soil 368, 375-392.

Callesen, I., Stupak, I., Georgiadis, P., Johannsen, V. K., Østergaard, H. S., Vesterdal, L. (2015): Soil carbon stock change in the forests of Denmark between 1990 and 2008. Geoderma Regional 5, 169-180.

Carbone, M. S., Czimczik, C. I., McDuffee, K. E., Trumbore, S. E. (2007): Allocation and residence time of photosynthetic products in a boreal forest using a low-level ${ }^{14} \mathrm{C}$ pulse-chase labeling technique. Global Change Biology 13, 466-477.

Cesarz, S., Fender, A. C., Beyer, F., Valtanen, K., Pfeiffer, B., Gansert, D., Hertel, D., Polle, A., Daniel, R., Leuschner, C.,Scheu, S. (2013): Roots from beech (Fagus sylvatica L.) and ash (Fraxinus excelsior L.) differentially affect soil microorganisms and carbon dynamics. Soil Biology and Biochemistry 61, 23-32.

Compton, J. E.,Boone, R. D. (2002): Soil nitrogen transformations and the role of light fraction organic matter in forest soils. Soil Biology and Biochemistry 34, 933-943.

Dambrine, E., Martin, F., Carisey, N., Granier, A., Hallgren, J.-E.,Bishop, K. (1995): Xylem sap composition: A tool for investigating mineral uptake and cycling in adult spruce. In L. O. Nilsson, R. F. Huttl and U. T. Johansson: Developments in Plant and Soil Sciences; Nutrient uptake and cycling in forest ecosystems, 233-241.

Dannoura, M., Maillard, P., Fresneau, C., Plain, C., Berveiller, D., Gerant, D., Chipeaux, C., Bosc, A., Ngao, J., Damesin, C., Loustau, D.,Epron, D. (2011): In situ assessment of the velocity of carbon transfer by tracing ${ }^{13} \mathrm{C}$ in trunk $\mathrm{CO}_{2}$ efflux 
after pulse labelling: variations among tree species and seasons. New Phytologist 190, 181-192.

Dyckmans, J.,Flessa, H. (2001): Influence of tree internal $\mathrm{N}$ status on uptake and translocation of $\mathrm{C}$ and $\mathrm{N}$ in beech: a dual ${ }^{13} \mathrm{C}$ and ${ }^{15} \mathrm{~N}$ labeling approach. Tree Physiology 21, 395-401.

Epron, D., Bahn, M., Derrien, D., Lattanzi, F. A., Pumpanen, J., Gessler, A., Hogberg, P., Maillard, P., Dannoura, M., Gerant, D.,Buchmann, N. (2012): Pulse-labelling trees to study carbon allocation dynamics: a review of methods, current knowledge and future prospects. Tree Physiology 32, 776-798.

Epron, D., Ngao, J., Dannoura, M.,Bakker, M. R. (2011): Seasonal variations of belowground carbon transfer assessed by in situ ${ }^{13} \mathrm{CO}_{2}$ pulse labelling of trees. Biogeosciences, 1153-1168.

Esperschütz, J., Gattinger, A., Buegger, F., Lang, H., Munch, J. C., Schloter, M.,Winkler, J. B. (2009): A continuous labelling approach to recover photosynthetically fixed carbon in plant tissue and rhizosphere organisms of young beech trees (Fagus sylvatica L.) using ${ }^{13} \mathrm{C}$ depleted $\mathrm{CO}_{2}$. Plant and Soil 323, 21-29.

Gearing, P. J., Gearing, J. N., Maughan, J. T.,Oviatt, C. A. (1991): Isotopic distribution of carbon from sewage sludge and eutrophication in the sediments and food web of Estuarine ecosystems. Environmental Science \& Technology 25, 295-301.

Gessler, A., Schultze, M., Schrempp, S.,Rennenberg, H. (1998): Interaction of phloemtranslocated amino compounds with nitrate net uptake by the roots of beech (Fagus sylvatica) seedlings. Journal of Experimental Botany 49, 1529-1537.

Grassi, G., Millard, P., Gioacchini, P., Tagliavini, M. (2003): Recycling of nitrogen in the xylem of Prunus avium trees starts when spring remobilization of internal reserves declines. Tree Physiology 23, 1061-1068.

Guckland, A., Jacob, M., Flessa, H., Thomas, F. M.,Leuschner, C. (2009): Acidity, nutrient stocks, and organic-matter content in soils of a temperate deciduous forest with different abundance of European beech (Fagus sylvatica L.). Journal of Plant Nutrition and Soil Science 172, 500-511.

Hogberg, M. N., Briones, M. J. I., Keel, S. G., Metcalfe, D. B., Campbell, C., Midwood, A. J., Thornton, B., Hurry, V., Linder, S., Nasholm, T.,Hogberg, P. (2010): Quantification of effects of season and nitrogen supply on tree below-ground carbon transfer to ectomycorrhizal fungi and other soil organisms in a boreal pine forest. New Phytologist 187, 485-493.

Högberg, P., Högberg, M. N., Gottlicher, S. G., N.R., B., Keel, S. G., Metcalfe, D. B., Campbell, C., Schindlbacher, A., Hurry, V., Lundmark, T., Linder, S.,Nasholm, T. (2008): High temporal resolution tracing of photosynthate carbon from the tree canopy to forest soil microorganisms. New Phytologist 177, 220-228.

Jones, D. L., Nguyen, C.,Finlay, R. D. (2009): Carbon flow in the rhizosphere: carbon trading at the soil-root interface. Plant Soil 321, 5-33.

Keel, S. G., Campbell, C. D., Hogberg, M. N., Richter, A., Wild, B., Zhou, X., Hurry, V., Linder, S., Nasholm, T.,Hogberg, P. (2012): Allocation of carbon to fine root compounds and their residence times in a boreal forest depend on root size class and season. New Phytologist 194, 972-981.

Kooijman, A. M.,Cammeraat, E. (2010): Biological control of beech and hornbeam affects species richness via changes in the organic layer, $\mathrm{pH}$ and soil moisture characteristics. Functional Ecology 24, 469-477.

Kuzyakov, Y.,Domanski, G. (2000): Carbon input by plants into the soil. Review. Journal of Plant Nutrition and Soil Science 163, 421-431. 
Kuzyakov, Y.,Xu, X. (2013): Competition between roots and microorganisms for nitrogen: mechanisms and ecological relevance. New Phytologist 198, 656-669.

Kuzyakov, Y. V.,Larionova, A. A. (2006): Contribution of rhizomicrobial and root respiration to the $\mathrm{CO}_{2}$ emission from soil (A review). Eurasian Soil Science 39, 753-764.

Langenbruch, C., Helfrich, M.,Flessa, H. (2012): Effects of beech (Fagus sylvatica), ash (Fraxinus excelsior) and lime (Tilia spec.) on soil chemical properties in a mixed deciduous forest. Plant and Soil 352, 389-403.

Leake, J. R., Donnelly, D. P., Saunders, E. M., Boddy, L.,Read, D. J. (2001): Rates and quantities of carbon flux to ectomycorrhizal mycelium following ${ }^{14} \mathrm{C}$ pulse labeling of Pinus sylvestris seedlings: effects of litter patches and interaction with a wooddecomposer fungus. Tree Physiology 21, 71-82.

Litton, C. M., Raich, J. W.,Ryan, M. G. (2007): Carbon allocation in forest ecosystems. Global Change Biology 13, 2089-2109.

Mareschal, L., Bonnaud, P., Turpault, M. P.,Ranger, J. (2010): Impact of common European tree species on the chemical and physicochemical properties of fine earth: an unusual pattern. European Journal of Soil Science 61, 14-23.

McDowell, N. G., Bowling, D. R., Schauer, A., Irvine, J., Bond, B. J., Law, B. E., Ehleringer, $J$ J. $R$. (2004): Associations between carbon isotope ratios of ecosystem respiration, water availability and canopy conductance. Glob. Change Biol., 1767-1784.

Meinen, C., Hertel, D.,Leuschner, C. (2009): Biomass and morphology of fine roots in temperate broad-leaved forests differing in tree species diversity: is there evidence of below-ground overyielding? Oecologia 161, 99-111.

Millard, P. (1996): Ecophysiology of the internal cycling of nitrogen for tree growth. Journal of Plant Nutrition and Soil Science 159, 1-10.

Millard, P.,Grelet, G. A. (2010): Nitrogen storage and remobilization by trees: ecophysiological relevance in a changing world. Tree Physiology 30, 1083-1095.

Mortazavi, B., Chanton, J. P., Prater, J. L., Oishi, A. C., Oren, R., Katul, G. (2005): Temporal variability in ${ }^{13} \mathrm{C}$ of respired $\mathrm{CO}_{2}$ in a pine and a hardwood forest subject to similar climatic conditions. Oecologia, 57-69,.

Ostle, N., Ineson, P., Benham, D., Sleep, D. (2000): Carbon assimilation and turnover in grassland vegetation using an in situ $\left(\mathrm{CO}_{2}\right)-{ }^{13} \mathrm{C}$ pulse labelling system. Rapid Communications in Mass Spectrometry 14, 1345-1350.

Pausch, J.,Kuzyakov, Y. (2011): Photoassimilate allocation and dynamics of hotspots in roots visualized by ${ }^{14} \mathrm{C}$ phosphor imaging. Journal of Plant Nutrition and Soil Science 174, 12-19.

Perakis, S. S.,Hedin, L. O. (2001): Fluxes and fates of nitrogen in soil of an unpolluted oldgrowth temperate forest, southern Chile. Ecology 82, 2245-2260.

Plain, C., Gerant, D., Maillard, P., Dannoura, M., Dong, Y., Zeller, B., Priault, P., Parent, F.,Epron, D. (2009): Tracing of recently assimilated carbon in respiration at high temporal resolution in the field with a tuneable diode laser absorption spectrometer after in situ $\left(\mathrm{CO}_{2}\right)-{ }^{13} \mathrm{C}$ pulse labelling of 20 -year-old beech trees. Tree Physiology 29, 1433-1445.

Potthoff, M., Loftfield, N., Buegger, F., Wick, B., John, B., Joergensen, R. G., Flessa, H. (2003): The determination of delta ${ }^{13} \mathrm{C}$ in soil microbial biomass using fumigationextraction. Soil Biology and Biochemistry 35, 947-954. 
Preston, C. M.,Mead, D. J. (1994): Growth response and recovery of ${ }^{15} \mathrm{~N}$ fertelizer one and 8 growing season after application to Londgepole pine in British-Columbia. Forest Ecology and Management 65, 219-229.

Rangel-Castro, J. I., Prosser, J. I., Scrimgeour, C. M., Smith, P., Ostle, N., Ineson, P., Meharg, A., Killham, K. (2004): Carbon flow in an upland grassland: effect of liming on the flux of recently photosynthesized carbon to rhizosphere soil. Global Change Biology 10, 2100-2108.

Ryan, M. G., Hubbard, R. M., Pongracic, S., Raison, R. J.,McMurtrie, R. E. (1996): Foliage, fine-root, woody-tissue and stand respiration in Pinus radiata in relation to nitrogen status. Tree Physiology 16, 333-343.

Schleuss, P. M., Heitkamp, F., Leuschner, C., Fender, A. C.,Jungkunst, H. F. (2014): Higher subsoil carbon storage in species-rich than species-poor temperate forests. Environmental Research Letters 9, 10.

Schütt, P., Weisberger, H., Schuck, H. J., Lang, U. M., Stimm, B.,Roloff, A. (2006): Enzyklopädie der Laubbäume. Nikol Verlagsgesellschaft mbH \& Co KG, Hamburg.

Shibistova, O., Yohannes, Y., Boy, J., Richter, A., Wild, B., Watzka, M., Guggenberger, G. (2012): Rate of Belowground Carbon Allocation Differs with Successional Habit of Two Afromontane Trees. Plos One 7.

Tietema, A., Emmett, B. A., Gundersen, P., Kjønaas, O. J.,Koopmans, C. J. (1998): The fate of ${ }^{15} \mathrm{~N}$ labelled nitrogen deposition in coniferous forest ecosystems. Forest Ecology and Management 101, 19-27.

Vesterdal, L., Schmidt, I. K., Callesen, I., Nilsson, L. O.,Gundersen, P. (2008): Carbon and nitrogen in forest floor and mineral soil under six common European tree species. Forest Ecology and Management 255, 35-48.

Warren, J. M., Iversen, C. M., Garten, C. T., Norby, R. J., Childs, J., Brice, D., Evans, R. M., Gu, L., Thornton, P.,Weston, D. J. (2012): Timing and magnitude of C partitioning through a young loblolly pine (Pinus taeda L.) stand using ${ }^{13} \mathrm{C}$ labeling and shade treatments. Tree Physiology 32, 799-813.

Werth, M., Subbotina, I.,Kuzyakov, Y. (2006): Three-source partitioning of $\mathrm{CO}_{2}$ efflux from soil planted with maize by ${ }^{13} \mathrm{C}$ natural abundance fails due to inactive microbial biomass. Soil Biology and Biochemistry 38, 2772-2781.

Wichern, F., Andreeva, D., Joergensen, R. G.,Kuzyakov, Y. (2011): Stem labeling results in different patterns of ${ }^{14} \mathrm{C}$ rhizorespiration and ${ }^{15} \mathrm{~N}$ distribution in plants compared to natural assimilation pathways. Journal of Plant Nutrition and Soil Science 174, 732-741.

Wingate, L., Ogee, J., Burlett, R., Bosc, A., Devaux, M., Grace, J., Loustau, D., Gessler, A. (2010): Photosynthetic carbon isotope discrimination and its relationship to the carbon isotope signals of stem, soil and ecosystem respiration. New Phytologist 188, 576-589.

Wurth, M. K. R., Pelaez-Riedl, S., Wright, S. J.,Korner, C. (2005): Non-structural carbohydrate pools in a tropical forest. Oecologia 143, 11-24.

Youssefi, F., Brown, P. H., Weinbaum, S. A. (2000): Relationship between tree nitrogen status, xylem and phloem sap amino acid concentrations, and apparent soil nitrogen uptake by almond trees (Prunus dulcis). Journal of Horticultural Science \& Biotechnology 75, 62-68. 


\title{
2.1.8 Supplementary material
}

Supplementary material for

\section{Allocation and dynamics of $\mathbf{C}$ and $\mathbf{N}$ within plant-soil system of ash and beech}

\author{
Journal of Plant Nutrition and Soil Science \\ Janine Sommer $^{1 *}$, Michaela Dippold ${ }^{2}$, Heiz Flessa ${ }^{3}$, Yakov Kuzyakov ${ }^{1,2}$
}

1 Soil Science of Temperate Ecosystems, University of Göttingen 37077 Göttingen, Germany

2 Agricultural Soil Science, Georg-August-University Göttingen, 37077 Göttingen, Germany

${ }^{3}$ Institute of Climate-Smart Agriculture, Thünen Institute, 38116 Braunschweig, Germany

Email of the corresponding author*: sommer.janine@yahoo.de 
Table 2.1-2: Mean temperature and humidity, during the labeling period for ${ }^{13} \mathrm{C}$ from 8 am to $7 \mathrm{pm}$

Day of labeling Mean Temperature $\left({ }^{\circ} \mathrm{C}\right)$

\begin{tabular}{lcc} 
& $+/-$ SD & $+/-$ SD \\
\hline 16.08 .2011 & $17 \pm 2$ & $80 \pm 7$ \\
17.08 .2011 & $21 \pm 3$ & $68 \pm 20$ \\
18.08 .2011 & $22 \pm 3$ & $72 \pm 12$ \\
\hline
\end{tabular}

\section{Mean relative Humitidy}

(\%)

\begin{tabular}{|c|c|c|c|c|c|}
\hline $\begin{array}{l}\text { Linear Regression of the relative }{ }^{13} \mathrm{C} \\
\text { and }{ }^{15} \mathrm{~N} \text { incorporation over time in }\end{array}$ & Slope & $\begin{array}{l}\text { Y-axis } \\
\text { gap }\end{array}$ & $\begin{array}{l}\text { Regression } \\
\text { coefficent } R^{2}\end{array}$ & $\begin{array}{l}\text { Significance } \\
\text { p-value }\end{array}$ & $\begin{array}{c}\mathrm{F}- \\
\text { value }\end{array}$ \\
\hline Beech soil 0-10 cm & 0.014 & 0.631 & 0.115 & 0.577 & 0.389 \\
\hline Beech soil $10-20 \mathrm{~cm}$ & 0.010 & -0.057 & 0.232 & 0,411 & 0.907 \\
\hline Beech soil $20-30 \mathrm{~cm}$ & 0.001 & 0.423 & 0.001 & 0.954 & 0.004 \\
\hline Ash soil 0-10 cm & 0.010 & -0.057 & 0.232 & 0.411 & 0.907 \\
\hline Ash soil $10-20 \mathrm{~cm}$ & 0.084 & 0.043 & 0.832 & 0.031 & 14.864 \\
\hline Ash soil $20-30 \mathrm{~cm}$ & 0.002 & 0.109 & 0.125 & 0.559 & 0.429 \\
\hline Beech Mibi 0-10 cm & 0.012 & 0.401 & 0.267 & 0.373 & 1.0912 \\
\hline Beech Mibi $10-20 \mathrm{~cm}$ & 0.005 & 0.053 & 0.455 & 0.212 & 2.500 \\
\hline Beech Mibi $20-30 \mathrm{~cm}$ & 0.008 & 0.153 & 0.285 & 0.354 & 1.196 \\
\hline Ash Mibi 0-10 cm & 0.062 & -0.734 & 0.900 & 0.014 & 26.906 \\
\hline Ash Mibi $10-20 \mathrm{~cm}$ & 0.002 & 0.325 & 0.012 & 0.859 & 0.037 \\
\hline Ash Mibi $20-30 \mathrm{~cm}$ & 0.018 & -0.284 & 0.658 & 0.096 & 5.770 \\
\hline
\end{tabular}




\section{Study 2}

\subsection{The tree species matters: Belowground carbon input and utilization in the myco-rhizosphere}

JANINE SOMMER ${ }^{1}$, MICHAELA A. DIPPOLD ${ }^{3}$, SARAH L. ZIEGER ${ }^{2}$,

ANIKA HANDKE ${ }^{1}$, STEFAN SCHEU ${ }^{2}$, YAKOV KUZYAKOV ${ }^{1,3}$

Submitted to European Journal of Soil Biology

${ }^{1}$ Georg-August-University Göttingen, Soil Science of Temperate Ecosystems, Büsgenweg 2, 37077 Göttingen, Germany

${ }^{2}$ Georg-August-University Göttingen, J.F. Blumenbach Institute of Zoology and Anthropology, Berliner Str. 28, 37073 Göttingen, Germany

${ }^{3}$ Georg-August-University Göttingen, Agricultural Soil Science, Büsgenweg 2, 37077 Göttingen, Germany

*corresponding author

Department of Soil Science of Temperate Ecosystems, Georg-August-University Göttingen, 37077 Göttingen, Germany

Phone: + 49(0)15773857055 Fax + 49(0)551393310

email: sommer.janine@yahoo.de 


\section{Abstract}

Rhizodeposits act as major carbon (C) source for microbial communities and rhizospheredriven effects on forest $C$ cycling receive increasing attention for maintaining soil biodiversity and ecosystem functions. By in situ ${ }^{13} \mathrm{CO}_{2}$ pulse labeling we investigated microbial utilization of rhizodeposits by analyzing ${ }^{13} \mathrm{C}$ incorporation into phospholipid fatty acids (PLFA) of beech- (Fagus sylvatica) and ash-associated (Fraxinus excelsior) rhizomicrobial communities. Plant compartments and soil samples were analyzed to quantify the allocation of assimilates. For trees of similar height $(\sim 1 \mathrm{~m})$, ash assimilated more of the applied ${ }^{13} \mathrm{CO}_{2}(31 \%)$ than beech $(21 \%)$, and ash allocated twice as much ${ }^{13} \mathrm{C}$ belowground until day 20 . Approximately $0.01 \%$ of the applied ${ }^{13} \mathrm{C}$ was incorporated into total PLFAs, but incorporation varied significantly between microbial groups. Saprotrophic and ectomycorrhizal fungi under beech and ash - but also arbuscular mycorrhizal fungi and Gram negative bacteria under ash - incorporated most ${ }^{13} \mathrm{C}$, with incorporation decreasing from day 5 to 20 . This indicates tree-species-specific $C$ turnover in microbial groups. PLFA allowed differentiation of $C$ fluxes from trees into mycorrhiza as twice as much ${ }^{13} \mathrm{C}$ was incorporated into the fungal biomarker 18:2w6.9 under beech than under ash. Within 5 days, $30 \%$ of the fungal PLFA-C was replaced by rhizodeposit-derived ${ }^{13} \mathrm{C}$ under beech but only $10 \%$ under ash. None of the other microbial groups reached a similarly high $C$ replacement, suggesting direct $C$ allocation via ectomycorrhizal symbioses dominates the $C$ flux belowground. Overall, the results suggest that the $C$ cycle in forest soils depends on tree species-specific rhizodeposition and mycorrhizal root associations.

Key-words: ${ }^{13} \mathrm{CO}_{2}$ labeling, Carbon cycle, Tree rhizodeposition; Species effects, Deciduous forest, PLFA 


\subsubsection{Introduction}

The total forest area of the world in 2005 was estimated to be about 4 billion ha or $30 \%$ of the total land area [1]. Forests store $80 \%$ of the terrestrial aboveground biomass and thus determine the $\mathrm{C}$ balance of terrestrial ecosystems [2]. An estimated $73.5 \mathrm{t} \mathrm{ha}^{-1}$ of carbon (C) are stored in the soils $(0-30 \mathrm{~cm})$ of the world's forests, which is more than in the living tree biomass $\left(71.5 \mathrm{t} \mathrm{ha}^{-1}\right)$ [1]. The $\mathrm{C}$ stock in the litter horizon of European forests is estimated to be $6.1 \mathrm{t} \mathrm{ha}^{-1}$ and the $\mathrm{C}$ stock in mineral soil $113 \mathrm{t} \mathrm{ha}^{-1}$ [1]. Beech is the most common deciduous tree in Germany, covering an area of 1.68 million ha, which is $15.4 \%$ of the entire forest area [3]. Beech therefore is of great economic value and ecological importance in Central Europe [4]. Ash makes up ca. 10\% of the forest area in Germany and is seen as a promising species for the future forestry industry [5]. These two tree species therefore are major representatives of forests in Germany and taken as model species for investigating $C$ allocation of trees belowground [6, 7]. Notably, the link between tree species identity and soil microorganisms in mixed-species forests remains little studied [8].

C allocation to roots and into the rhizosphere has received little attention in trees [9-11]. Up to $90 \%$ of the net primary production of trees enters the soil as detritus [12], where fungi and bacteria subsist on rhizodeposits and show a high metabolic versatility. The amount, composition and dynamics of rhizodeposits and their ecological functions, especially those of trees, are poorly investigated [13]. This calls for focusing on feedback mechanisms between rhizodeposits and the microbial community composition.

Phospholipids - biomarkers for microbial community composition - are fundamental membrane components of all living cells [2]. Certain fatty acids are marker molecules for certain microbial groups [14] and can be used to characterize microbial communities, including Gram positive and Gram negative bacteria as well as fungi. They also can be used to assess the effects of plant species diversity on soil microbial communities [2]. Gram negative and Gram positive bacteria differ not only in their cell wall composition but also in their ecophysiological functions [15].

This study was part of a nine-year project that investigated soil organic matter (SOM) formation under broad-leaved trees dominating in Germany. SOM stocks were higher in mixed stands as compared to mono-specific stands [16, 17]. SOM accumulation in the litter layer was highest under beech $\left(0.81 \mathrm{~kg} \mathrm{~m}^{-2}\right)$ and lowest in stands with highest diversity and the lowest abundance of beech $\left(0.27 \mathrm{~kg} \mathrm{~m}^{-2}\right)$ [18]. Beech accumulates more $\mathrm{C}_{\text {org }}$ in the forest floor but less $\mathrm{C}_{\text {org }}$ in the mineral soil as compared to ash, confirming that 
the species-specific litter quality affects major characteristics of forest soils [19]. Beech litter has high C-to-N ratio (53) and high lignin content (85 $\mathrm{mg} \mathrm{g}^{-1}$ dry matter), which retards decomposition processes. Ash litter, in contrast, is characterized by high quality, low C-to-N ratio (31) and low lignin content $\left(25.3 \mathrm{mg} \mathrm{g}^{-1}\right.$ dry matter) $[18,20,21]$. Therefore, ash litter decomposes faster than beech litter, returning nutrients to the soil faster [22, 23].

We chose ash and beech not only because of their different litter quality and nutrient allocation patterns, but also because of differences in root morphology and mycorrhiza types [24]. Beech roots are associated with ectomycorrhizal (ECM) fungi such as Byssocorticium atrovirens, Lactarius subdulcis and Xerocomus chrysenteron, which are also saprotrophic and decompose diverse carbon sources [25]. In contrast, ash roots are associated with arbuscular mycorrhizal fungi [24] and ash presents a typical tap root system. Beech has a heart root system in which several major roots are developed, growing downward in parallel [26]. Ash exhibits fine roots of larger diameter, lower specific root area and lower specific root tip abundance than beech [24].

We hypothesized 1) the composition of microbial groups under beech to differ from that under ash, and 2) belowground $\mathrm{C}$ allocation and transformation to differ between microbial groups. In detail, we expected saprotrophic fungi to be more abundant under beech than under ash, and AMF to be more abundant under ash than under beech. We used PLFAs to investigate differences in microbial community structure under the two tree species. To analyze the incorporation of rhizodeposits into microorganisms, we pulse labeled ash and beech trees with ${ }^{13} \mathrm{CO}_{2}$. We quantified the allocation of rhizodeposits into various microbial groups by ${ }^{13} \mathrm{C}$-PLFA and inspected $\mathrm{C}$ incorporation into individual microbial groups, especially into mycorrhizal fungi and Gram negative bacteria. 


\subsubsection{Material and Methods}

\subsubsection{Site description}

The experimental site - Göttinger Wald (5135'15.39"N 958'57.95"E, 362 AMSL) - is located southeast of Göttingen, Lower Saxony, Germany. The region is characterized by mild winters and humid summers with an annual precipitation of $613 \mathrm{~mm}$ and a mean annual temperature of $8.7^{\circ} \mathrm{C}$ [27]. The Göttinger Wald is a 130-145-year-old beech forest scattered with ash and maple. The soil is an Orthic Renzina with typical mull humus [28]. The $\mathrm{pH}$ of the topsoil varies between 4.4 and 7.0 [29, 30]. Forty ash and 40 beech trees with a height of ca. $1 \mathrm{~m}(73-177 \mathrm{~cm})$ were chosen in May 2012.

\subsubsection{Experimental design and sampling setup}

Ash and beech seedlings (approx. $1 \mathrm{~m}$ ) were taken from the forest with undisturbed soil, and the entire soil core was placed into $23-\mathrm{cm}$-diameter pots of a depth of $26 \mathrm{~cm}$. The trees had a reestablishment time of 2 months; they were kept in a shaded area under the canopy of mature beech trees and then transferred to an outdoor greenhouse. The seedlings were irrigated regularly, and herbs were removed by cutting the shoots at the soil surface. Shortly before the start of the experiment, the pot was wrapped with plastic and closed airtight with Terostat (Teroson Terostat-VII, Henkel, Düsseldorf, Germany) to avoid ${ }^{13} \mathrm{CO}_{2}$ re-uptake from soil respiration [10]. An irrigation system was established consisting of PVC tubes (Deutsch \& Neumann, Berlin, Germany) with an inner diameter of $6 \mathrm{~mm}$ and fixed with cable ties to the plastic wrapping (OBO Bettermann $\mathrm{GmbH} \&$ Co. KG, Menden, Germany). A ventilation system was used within the plastic bags.

The ${ }^{13} \mathrm{CO}_{2}$ pulse labeling was conducted on 20 ashes and 20 beeches in a chamber with a surface area of $1 \times 1 \mathrm{~m}^{2}$ and approximately $2 \mathrm{~m}$ high [31, 32]. Twenty beeches and 20 ashes remained unlabeled as reference trees. Conditions in the chamber were kept at $1,013 \mathrm{hPa}, 20^{\circ} \mathrm{C}$ and $70 \%$ relative humidity; light intensity was $420 \mu \mathrm{E}$ for $16 \mathrm{~h} \mathrm{day}^{-1}$. The seedlings were labeled in four labeling periods involving batches of ten seedlings each. Five beech and ash seedlings of each batch were sampled immediately after three days labeling with ${ }^{13} \mathrm{CO}_{2}$ and two days exposure to ${ }^{12} \mathrm{CO}_{2}$ : Another 5 beech and ash seedlings of each batch were sampled 20 days after the start of the labeling. The reference seedlings were kept under similar conditions.

Seedlings were acclimatized for two days in the chamber at $400 \mathrm{ppm}$ with unlabeled $\mathrm{CO}_{2}$ produced by injecting 5 molar lactic acid in a 0.5 molar solution of ${ }^{12} \mathrm{C}$ sodium carbonate (KMF Laborchemie Handes, Lohmar, Germany). The ${ }^{13} \mathrm{CO}_{2}$ pulse was produced by 
injecting 5 molar lactic acid into a 0.5 molar ${ }^{13} \mathrm{C}$ sodium-carbonate $\left(\mathrm{Na}_{2} \mathrm{CO}_{3}\right)$ solution (Sigma-Aldrich, Traufkirchen, Germany) enriched with 99 atom\% ${ }^{13} \mathrm{C}$. The seedlings were exposed to ${ }^{13} \mathrm{CO}_{2}$ for three days and to ${ }^{12} \mathrm{CO}_{2}$ for two days for $16 \mathrm{~h} \mathrm{day}^{-1}$ with a maximum $\mathrm{CO}_{2}$ concentration of $1800 \mathrm{ppm}$. The $\mathrm{CO}_{2}$ concentration in the chamber was monitored using an infrared gas analyzer (CARBOCAP' ${ }^{\mathrm{TM}}$ Serie GMM220, Driesen + Kern $\mathrm{GmbH}$, Bad Bramstedt, Germany). To reduce dilution of the ${ }^{13} \mathrm{CO}_{2}$ by plant-derived $\mathrm{CO}_{2}$ at night, $\mathrm{CO}_{2}$ in the chamber was absorbed by pumping the air through a $1 \mathrm{M} \mathrm{NaOH}$ solution.

Samples of 5 beech and 5 ash seedlings and 5 reference seedlings of each species were harvested 5 and 20 days after the $\mathrm{CO}_{2}$ pulse labeling. Soil was sampled next to the stem of the tree in the pot with a split tube. The intact core was sampled at depths of $0-10 \mathrm{~cm}$ and below $10 \mathrm{~cm} 5$ and 20 days after labeling. Only the $0-10 \mathrm{~cm}$ depth sample was considered because the highest ${ }^{13} \mathrm{C}$ incorporation into microbial biomass was recorded in the top $10 \mathrm{~cm}$ in a field experiment under beech and ash [9]. The soil was removed from the column, weighed and the water content was determined in a subsample. Each soil sample was sieved to $2 \mathrm{~mm}$ and stored at $-20^{\circ} \mathrm{C}$ until PLFA analysis.

\subsubsection{PLFA analysis and calculation}

\subsection{Phospholipid extraction, purification, derivatization and measurement}

An improved method of Frostegård et al. [33] was used to extract and purify phospholipids (for details see [34]). Six grams of soil were used for extraction and polar lipids were eluted four times with $5 \mathrm{ml}$ of water-free methanol. Twenty-five milliliters of the internal standard 1 (IS 1) phosphatidylcholine-dinonadecanoic acid (1 $\mathrm{mg} \mathrm{ml}^{-1}$ in methanol) were added prior to extraction. Fatty acids were saponified to free fatty acids and derivatized into fatty acid methyl esters (FAMEs) [35] for measurement on a GC. Fifteen milliliters of an internal standard 2 (IS 2) tridecanoic acid methyl ester ( $1 \mathrm{mg} \mathrm{ml}^{-1}$ in toluene) were added before the samples were transferred to auto sampler vials. External standards consisting of the 27 fatty acids given in Supplementary Table 2.2-3 and internal standard 1 were prepared with total fatty acid contents of $1.0,4.5,9.0,18.0,24.0$ and $30.0 \mathrm{mg}$, respectively, and derivatized and measured together with the samples.

Table 2.2-1 lists the grouping of the individual fatty acids, whereby each of these groups represents an ecophysiological or functional microbial group in soil. The table includes only those fatty acids that are not ubiquitous but at least partially specific for a certain microbial group. 
Table 2.2-1: Identified microbial groups and their specific fatty acid amounts (mean \pm SEM) in soil of beech and ash seedlings.

\begin{tabular}{|c|c|c|c|c|c|c|}
\hline \multirow[t]{2}{*}{ Microbial groups } & \multirow[t]{2}{*}{ Abbreviation } & \multirow[t]{2}{*}{ Fatty acids } & \multicolumn{2}{|c|}{$\begin{array}{l}\text { Under beech } \\
\begin{array}{c}\left(\mu \mathrm{g} \mathrm{g}^{-1} \mathrm{dry}\right. \\
\text { soil) }\end{array}\end{array}$} & \multicolumn{2}{|c|}{$\begin{array}{l}\text { Under ash } \\
\left(\mu g^{-1} \text { dry }\right. \\
\text { soil) }\end{array}$} \\
\hline & & & day 5 & $\begin{array}{l}\text { day } \\
20\end{array}$ & day 5 & day 20 \\
\hline Gram positive 1 & $\mathrm{G}+1$ & $\begin{array}{c}\mathrm{i} 14: 0 \\
\mathrm{a} 16: 0 \\
\mathrm{i} 17: 0 \\
20: 1 \omega 9\end{array}$ & $\begin{array}{l}0.030 \\
\pm \\
0.002\end{array}$ & $\begin{array}{l}0.040 \\
\pm \\
0.007\end{array}$ & $\begin{array}{c}0.032 \\
\pm \\
0.003\end{array}$ & $\begin{array}{r}0.035 \\
\pm 0.002\end{array}$ \\
\hline Gram positive 2 & $\mathrm{G}+2$ & i15:0 & $\begin{array}{l}0.067 \\
\pm \\
0.001\end{array}$ & $\begin{array}{l}0.074 \\
\pm \\
0.002\end{array}$ & $\begin{array}{l}0.076 \\
\pm \\
0.003\end{array}$ & $\begin{array}{l}0.074 \\
\pm \\
0.001\end{array}$ \\
\hline Gram positive 3 & $\mathrm{G}+3$ & $\begin{array}{l}\text { a15:0 } \\
\text { a17:0 }\end{array}$ & $\begin{array}{l}0.076 \\
\pm \\
0.004\end{array}$ & $\begin{array}{l}0.069 \\
\pm \\
0.005\end{array}$ & $\begin{array}{l}0.087 \\
\pm \\
0.007\end{array}$ & $\begin{array}{l}0.079 \\
\pm \\
0.002\end{array}$ \\
\hline Gram positive 4 & $\mathrm{G}+4$ & i16:0 & $\begin{array}{l}0.030 \\
\pm \\
0.001\end{array}$ & $\begin{array}{l}0.030 \\
\pm \\
0.002\end{array}$ & $\begin{array}{c}0.028 \\
\pm \\
0.001\end{array}$ & $\begin{array}{l}0.026 \\
\pm \\
0.001\end{array}$ \\
\hline Actinomycetes 1 & Ac1 & 10Me16:0 & $\begin{array}{l}0.022 \\
\pm \\
0.001\end{array}$ & $\begin{array}{c}0.028 \\
\pm \\
0.003\end{array}$ & $\begin{array}{c}0.028 \\
\pm \\
0.002\end{array}$ & $\begin{array}{l}0.022 \\
\pm \\
0.001\end{array}$ \\
\hline Actinomycetes 2 & Ac2 & 10Me18:0 & $\begin{array}{l}0.030 \\
\pm \\
0.002\end{array}$ & $\begin{array}{l}0.018 \\
\pm \\
0.002\end{array}$ & $\begin{array}{c}0.028 \\
\pm \\
0.004\end{array}$ & $\begin{array}{l}0.023 \\
\pm \\
0.001\end{array}$ \\
\hline Gram negative 1 & G-1 & $\begin{array}{l}16: 1 \omega 7 \\
\text { cy17:0 }\end{array}$ & $\begin{array}{l}0.061 \\
\pm \\
0.001\end{array}$ & $\begin{array}{l}0.069 \\
\pm \\
0.004\end{array}$ & $\begin{array}{l}0.067 \\
\pm \\
0.003\end{array}$ & $\begin{array}{l}0.04 \pm \\
0.001\end{array}$ \\
\hline $\begin{array}{l}\text { Gram negative 2/ } \\
\text { Arbuscular mycorrhizal fungi }\end{array}$ & G-2 & $18: 1 \omega 7$ & $\begin{array}{l}0.114 \\
\pm \\
0.011\end{array}$ & $\begin{array}{l}0.099 \\
\pm \\
0.010\end{array}$ & $\begin{array}{l}0.108 \\
\pm \\
0.008\end{array}$ & $\begin{array}{l}0.104 \\
\pm \\
0.003\end{array}$ \\
\hline Gram negative 3 & G-3 & cy19:0 & $\begin{array}{l}0.160 \\
\pm \\
0.009\end{array}$ & $\begin{array}{l}0.136 \\
\pm \\
0.017\end{array}$ & $\begin{array}{l}0.137 \\
\pm \\
0.008\end{array}$ & $\begin{array}{l}0.142 \\
\pm \\
0.005\end{array}$ \\
\hline $\begin{array}{l}\text { Gram negative/ } \\
\text { Fungi }\end{array}$ & $\mathrm{G}-/ \mathrm{F}$ & $18: 1 \omega 9$ & $\begin{array}{c}0.075 \\
\pm \\
0.004\end{array}$ & $\begin{array}{l}0.069 \\
\pm \\
0.005\end{array}$ & $\begin{array}{l}0.058 \\
\pm \\
0.003\end{array}$ & $\begin{array}{l}0.056 \\
\pm \\
0.002\end{array}$ \\
\hline $\begin{array}{l}\text { Saprothrophic } \\
\text { Ectomycorrhizal } \\
\text { Animals }\end{array}$ & SF & $18: 2 \omega 6.9$ & $\begin{array}{c}0.028 \\
\pm \\
0.001\end{array}$ & $\begin{array}{c}0.031 \\
\pm \\
0.003\end{array}$ & $\begin{array}{c}0.021 \\
\pm \\
0.004\end{array}$ & $\begin{array}{l}0.024 \\
\pm \\
0.001\end{array}$ \\
\hline $\begin{array}{ll}\text { Arbuscular } & \text { mycorrhizal } \\
\text { fungi/ Bacteria } & \end{array}$ & AMF & $16: 1 \omega 5$ & $\begin{array}{c}0.026 \\
\pm \\
0.002\end{array}$ & $\begin{array}{c}0.028 \\
\pm \\
0.003\end{array}$ & $\begin{array}{c}0.027 \\
\pm \\
0.002\end{array}$ & $\begin{array}{l}0.026 \\
\pm \\
0.001\end{array}$ \\
\hline $\begin{array}{l}\text { Protozoa/ } \\
\text { Animals widespread }\end{array}$ & $\operatorname{Pr}$ & $20: 4 \omega 6$ & $\begin{array}{c}0.102 \\
\pm \\
0.010\end{array}$ & $\begin{array}{c}0.097 \\
\pm \\
0.013 \\
\end{array}$ & $\begin{array}{c}0.128 \\
\pm \\
0.015 \\
\end{array}$ & $\begin{array}{c}0.132 \\
\pm \\
0.004\end{array}$ \\
\hline
\end{tabular}


2.2.2.3.2. Calculation of plant ${ }^{13} \mathrm{C}$ uptake and ${ }^{13} \mathrm{C}$ incorporation into plants and PLFA

Plant uptake from sources of different isotope composition results in changes in their isotopic signature and follows a two component mixing model [36],

$$
\left[{ }^{13} C\right]_{\text {ncTracer }}=[C]_{\text {component }} \cdot \frac{a t \%_{\text {labelled }}-a t \%_{\text {ref }}}{a t \%_{\text {appliedTraer }}-a t \%_{\text {ref }}}
$$

where $[\mathrm{C}]_{\text {component }}$ is the carbon content of the component $\left(\mathrm{mmol}_{\text {drycomponent }}{ }^{-1}\right)$ and $[\mathrm{C}]_{\text {inctracer }}$ is the total amount ${ }^{13} \mathrm{C}$ incorporated into the respective components, i.e. soil, leaf, stem and root, in (mmol gdrycomponent ${ }^{-1}$ ), at\%labelled is the ${ }^{13} \mathrm{C}$ of the labeled sample of the seedling (leaf, stem, root, soil), at\% ref the ${ }^{13} \mathrm{C}$ of the unlabeled reference sample of the seedling (leaf, stem, root, soil), and at\%applied Tracer the ${ }^{13} \mathrm{C}$ enrichment of the added $\mathrm{CO}_{2}$. The incorporation is not expressed as absolute incorporation, but divided by the amount of added ${ }^{13} \mathrm{C}$ to present incorporation as $\%$ of applied ${ }^{13} \mathrm{C}$.

The measurement of the FAMEs, calculations and drift corrections are described in detail in Dippold and Kuzyakov [37]. Subsequently, the ${ }^{13} \mathrm{C}$ incorporation into the PLFA $\left(\left[{ }^{13} \mathrm{C}\right]\right.$ incTracer-PLFA $)$ of the microbial community was determined according to equation 1 , using the PLFA amount ( $\mathrm{g} \mathrm{g}^{-1}$ dry soil) as pool size. Similar to the incorporation into tree biomass, incorporation into microbial PLFAs is presented as $\%$ of applied ${ }^{13} \mathrm{C}$.

\subsection{Calculation of PLFA replacement}

Besides ${ }^{13} \mathrm{C}$ incorporation, which yields a quantitative value for the ${ }^{13} \mathrm{C}$ flux into the membranes of a specific microbial group, the ${ }^{13} \mathrm{C}$ replacement was calculated. In contrast to the incorporation, the ${ }^{13} \mathrm{C}$ replacement is fully independent of pool size and merely represents the amount of a certain fatty acid that is replaced by newly incorporated ${ }^{13} \mathrm{C}$. Although this value does not provide the quantitative relevance of a $C$ flux into this microbial group, it does contain ecological information: it shows the relevance of the rhizodeposit-derived ${ }^{13} \mathrm{C}$ as a $\mathrm{C}$ source for the respective microbial group. Replacement of membrane lipids by ${ }^{13} \mathrm{C}$ is calculated by dividing the ${ }^{13} \mathrm{C}$ incorporation $\left[{ }^{13} \mathrm{C}\right]_{\text {inctracer }}$ of a certain fatty acid by the amount of $\mathrm{C}$ in this fatty acid (equation 2).

$$
{ }^{13} \mathrm{C} /{ }^{12} \mathrm{C}_{\text {repl }}=\left(\left[{ }^{13} \mathrm{C}\right]_{\text {inctracer-PLFA }} / \text { Total } \mathrm{C}_{\text {PLFA }}\right) * 100 \%
$$

with $\left[{ }^{13} \mathrm{C}\right]_{\text {incTracer-PLFA }}$ amount of ${ }^{13} \mathrm{C}$ incorporated into PLFA $\left(\mu \mathrm{mol} /{ }^{13} \mathrm{C}\right.$ per $\left.g_{\text {dry soil }}\right)$ 
Total $\mathrm{C}_{\mathrm{PLFA}}$

amount of PLFA Carbon ( $\mu \mathrm{mol} \mathrm{C}$ per $\left.\mathrm{g}_{\text {dry soil }}\right)$.

PLFAs were classified using the amounts of the individual fatty acids for corresponding microbial groups by factor analysis with a principal component extraction method. The classified data were compared with the literature for pure culture fatty acid fingerprints to determine functional microbial groups. Incorporation of ${ }^{13} \mathrm{C}$ into individual fatty acids was summed to quantify the incorporation of individual microbial groups.

\subsubsection{Statistical analysis}

The labeling and subsequent ${ }^{13} \mathrm{C}$ analyses were done with 10 independent replicates. Field replicates were tested for normal distribution using the Kolmogorov Smirnoff test, for homogeneous variances using Levene's test and corrected for outliers using the Nalimov outlier test with significance levels of $95 \%[38] .{ }^{13} \mathrm{C}$ enrichment and PLFAs as dependent variables were investigated for significant differences between tree species using Tukey's Honestly Significance Difference (Tukey's HSD) post hoc test $(p<0.05)$ following nested one-way analysis of variance (ANOVA) using Statistica (version 7, Statsoft $\mathrm{GmbH}$, Hamburg, Germany) to inspect effects of tree species on plant compartments and soil microbial groups. The error bars in graphs show standard errors of the mean (SEM) of the ten replicates. PLFAs were classified for corresponding microbial groups by a factor analysis of $\mathrm{C}$ contents of the entire dataset. Fatty acids were categorized according to previous studies [14,39] and combining fatty acid biomarker and their isotopic ratios will allow insights into belowground trophic interactions [40]. 


\subsubsection{Results}

\subsubsection{1 ${ }^{13} \mathrm{C}$ dynamics in trees and soil}

Beech had approximately twice as much leaf and stem biomass but less root biomass than ash (Table 2.2-2).

Table 2.2-2: Mean plant biomass ( \pm SEM), soil mass and specific leaf area of beech and ash

\begin{tabular}{lcc} 
& Beech & Ash \\
\hline Leaf biomass (g per tree) Mean +/- SEM & $8.7 \pm 0.5$ & $3.9 \pm 0.3$ \\
Stem biomass (g per tree) Mean +/- SEM & $37.0 \pm 1.7$ & $21.1 \pm 1.3$ \\
Root biomass (g per tree) Mean +/- SEM & $15.4 \pm 1.0$ & $20.3 \pm 1.1$ \\
Specific leaf area $\left(\mathrm{cm}^{2}\right)$ & $268 \pm 22$ & $566 \pm 91$ \\
\hline
\end{tabular}

Leaves, stem and roots of both species were highly enriched in ${ }^{13} \mathrm{C}$. Five days after the labeling, up to $20 \%$ and $30 \%$ of the applied ${ }^{13} \mathrm{CO}_{2}$ were recovered in all measured compartments of beech and ash, respectively (Figure 2.2-1). Ash assimilated one third more ${ }^{13} \mathrm{C}$ in all measured compartments but recovered with $34 \%$ twice as much in leaves as beech. In the stem, beech incorporated $8 \%{ }^{13} \mathrm{C}$ of the applied ${ }^{13} \mathrm{CO}_{2}$, i.e. four times more than ash. Ash significantly increased the ${ }^{13} \mathrm{C}$ in the stem by three times until day 20 after labeling, while ${ }^{13} \mathrm{C}$ values in beech remained constant. Furthermore, the ${ }^{13} \mathrm{C}$ incorporation was particularly pronounced in ash roots: approximately $48 \%$ of the ${ }^{13} \mathrm{C}$ in all compartments was recovered at day 5 in the roots (versus only $33 \%$ in beech). Approximately $10 \%$ of the ${ }^{13} \mathrm{C}$ incorporated in all compartments could be recovered after 5 days in the soil under both tree species and decreased to below 5\% until day 20 .

In summary, ash fixed $30 \%$ more ${ }^{13} \mathrm{C}$ by photosynthesis than beech. Beech showed a more rapid transport of photosynthates through the tree and allocated initially twice as much of the assimilated ${ }^{13} \mathrm{C}$ into the stem than ash, but only one fourth of the assimilated ${ }^{13} \mathrm{C}$ into the root. The ${ }^{13} \mathrm{C}$ incorporation into the soil did not differ between the species, but beech showed a significant ${ }^{13} \mathrm{C}$ release to the soil from day 5 to day 20. 


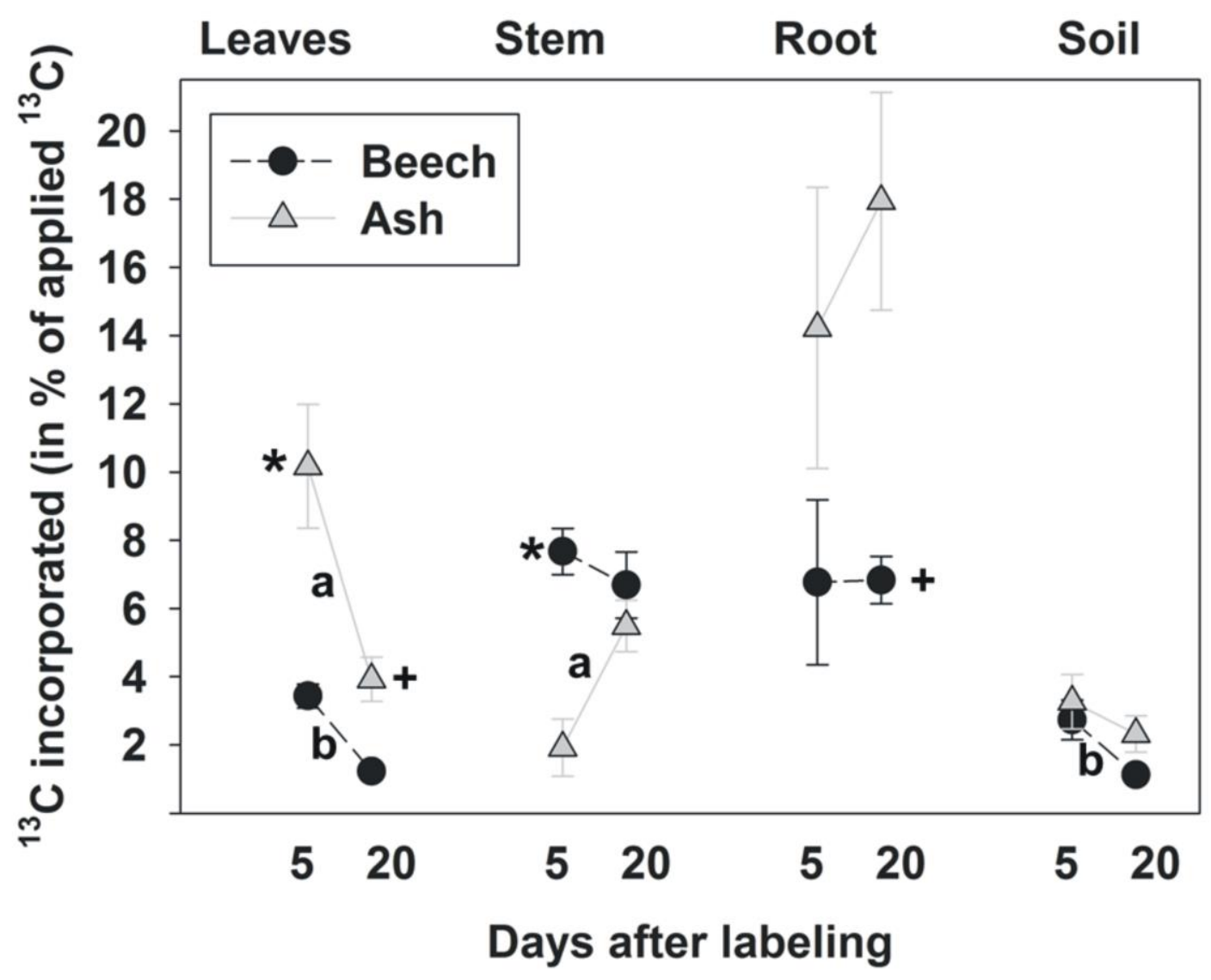

Figure 2.2-1: Total ${ }^{13} \mathrm{C}$ incorporation (\% $\pm S E M, N=10$ ) of the applied ${ }^{13} \mathrm{CO}_{2}$ in leaves, stem, roots and soil (0-10 cm depth) on day 5 and 20 after labeling of beech (black circles) and ash (grey triangles). * significant $(p<0.05)$ differences in ${ }^{13} \mathrm{C}$ incorporation in compartments between ash and beech on day 5, + significant differences on day 20 after labeling. Lower case letters show significant $(p<0.05)$ differences between day 5 and day 20 after labeling in beech (b) and ash (a).

\subsubsection{Abundance of microbial groups in ash and beech soil}

Many fatty acids within the Gram positives showed a deviating pattern, resulting in a subdivision into four groups. Similarly, four groups of Gram negatives and two groups of Actinomycetes were separated by the PCA.

The dominating PLFA groups under both tree species were Gram negatives, Gram negatives/Fungi and Protozoa. The lowest amounts of microbially derived fatty acids under both trees species were detected for actinomycetes, AMF and SF. In general, the PLFA amount in both tree species differed by only approximately $0.01 \mathrm{\mu g} \mathrm{g}^{-1}$ dry soil between species and between sampling dates. The fatty acids derived from the G-/F group were significantly higher under beech 5 days after labeling. In contrast, the Prderived fatty acids were higher under beech and displayed the highest amount of fatty 
acids $\left(0.16 \mu \mathrm{g} \mathrm{g}^{-1}\right.$ dry soil). Similarly, the sum of fatty acids under beech and ash did not differ significantly, reflecting steady state of the microbial biomass.

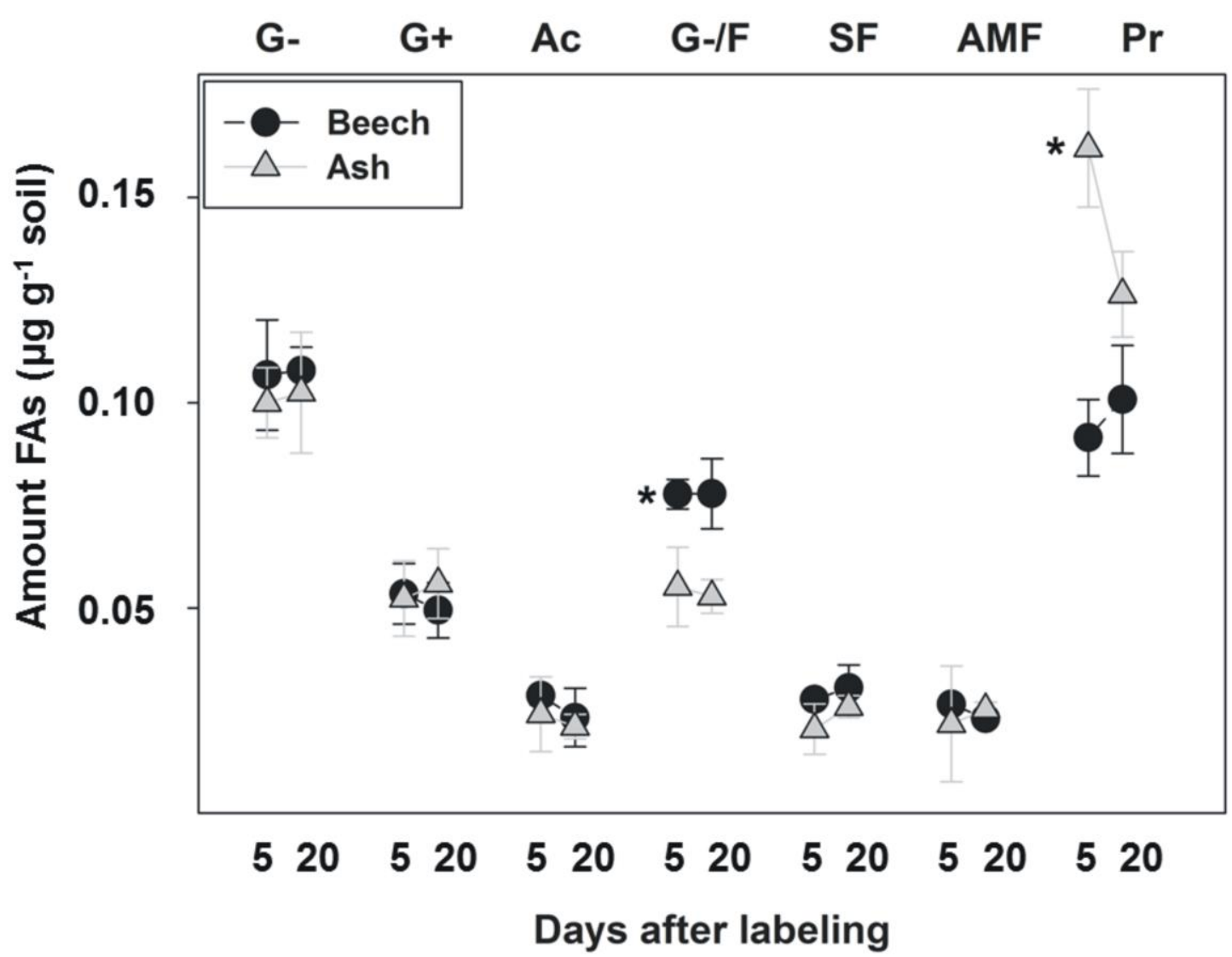

Figure 2.2-2: Amount of fatty acids ( $\mu \mathrm{g} \mathrm{g}^{-1}$ soil) in microbial groups in ash (grey triangle) and beech soil (black circle). Error bars show SEM $(N=10)$; * significant $(p<0.05)$ differences between the tree species 5 days after the start of the ${ }^{13} \mathrm{C}$ labeling.

\subsubsection{3 ${ }^{13} \mathrm{C}$ incorporation of PLFA of individual groups}

The microbial group SF (18:2w6.9) showed high ${ }^{13} \mathrm{C}$ incorporation in their PLFA $(0.010$ to $0.004 \%{ }^{13} \mathrm{C}$ of applied $\left.{ }^{13} \mathrm{CO}_{2}\right)$ both under beech at day 5 and 20 after labeling $(\mathrm{p}<0.05)$ and under ash (0.004 to $0.002 \%{ }^{13} \mathrm{C}$ of applied ${ }^{13} \mathrm{CO}_{2}$ ) (Figure 2.2-3). AMF and Gram negative 2 also showed high ${ }^{13} \mathrm{C}$ incorporation under ash and incorporated more ${ }^{13} \mathrm{C}(\mathrm{p}<$ 0.05) than under beech 5 and 20 days after labeling. The ${ }^{13} \mathrm{C}$ incorporation into the microbial groups under ash was higher than into the respective groups under beech by a factor of 2 to 12 .

In the SF and G-/F group the ${ }^{13} \mathrm{C}$ incorporated decreased by half from day 5 to 20 after labeling. Actinomycetes 1 increased the ${ }^{13} \mathrm{C}$ incorporation by a factor of two from day 5 to 20 after labeling in beech soil (in ash by a factor of four). The strongest drop in the ${ }^{13} \mathrm{C}$ 
incorporation in ash occurred in AMF, where only one third of the incorporation at day 5 remained at day 20. In general, the incorporation into Gram negatives, SF and $\operatorname{Pr}$ exceeded the incorporation into Gram positives and actinomycetes by a factor of 10 .

Especially SF under both tree species, but also AMF and Gram negative 2 bacteria under ash, displayed the highest ${ }^{13} \mathrm{C}$ incorporation and showed a fast drop from day 5 to 20 . The ${ }^{13} \mathrm{C}$ incorporation into PLFAs of mycorrhizal fungi confirmed the mycorrhization of the tree species.

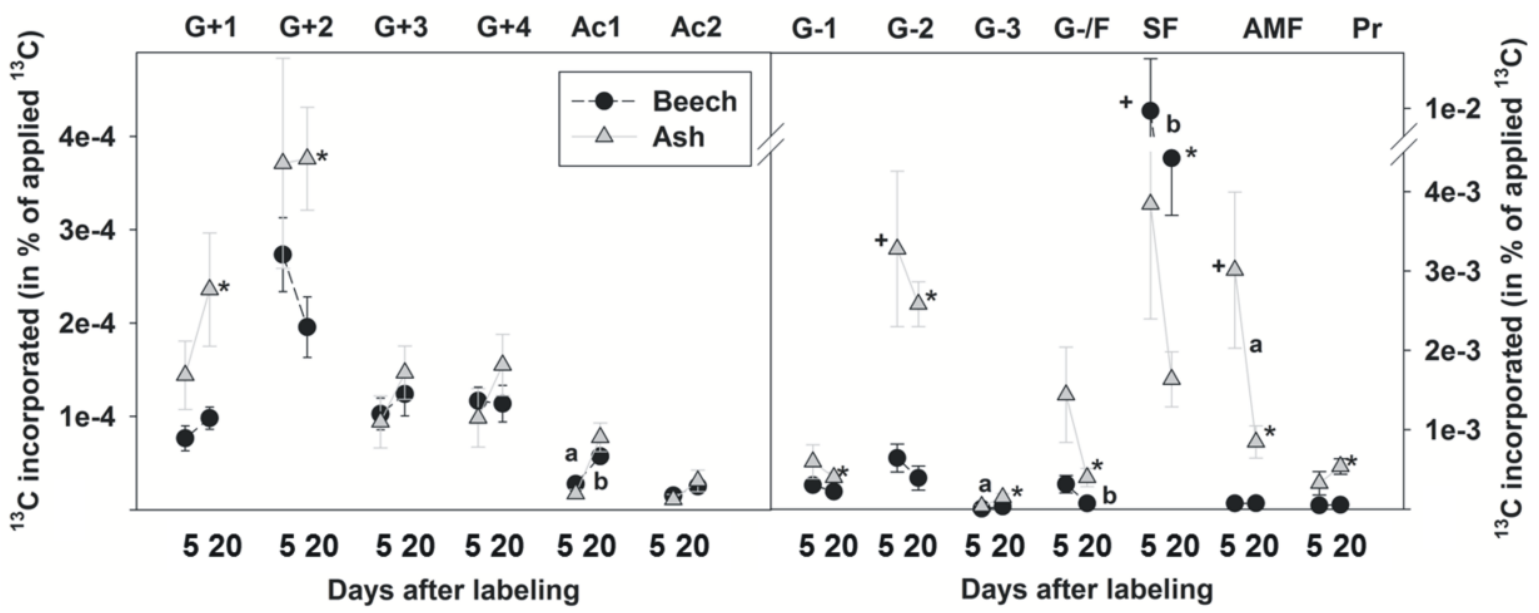

Figure 2.2-3: ${ }^{13} \mathrm{C}$ incorporation into PLFAs (\% of ${ }^{13} \mathrm{C}$ input) of applied $\mathrm{CO}_{2}$ in microbial groups in ash (grey triangle) and beech soil (black circle). Error bars show SEM $(N=10)$; + significant $(p<0.05)$ differences between beech and ash at day 5 and * at day 20 after labeling. Lower case letters indicate significant $(p<0.05)$ differences between day 5 and day 20 after labeling in beech (b) and ash (a).

\subsubsection{4 ${ }^{13} \mathrm{C}$ replacement of PLFA of individual groups}

Fungi in beech soil replaced more of their PLFA-C by ${ }^{13} \mathrm{C}$ than all other microbial groups (Figure 2.2-2). Microbes in ash soil replaced less of their PLFA-C by ${ }^{13} \mathrm{C}$ in the microbial group SF than in beech soil. Nonetheless, more ${ }^{13} \mathrm{C}$ in PLFAs were replaced in microbial group SF than in all other microbial groups in ash soil 20 days after labeling (Figure 2.2-4). Three microbial groups in ash soil also showed major differences in the replacement of their PLFA-C by ${ }^{13} \mathrm{C} 5$ days after labeling (Figure 2.2-2). Notably, Gram positives, actinomycetes and Gram negatives replaced less ${ }^{13} \mathrm{C}$ in their PLFAs than SF and AMF.

The $30 \% \mathrm{C}$ replacement within 5 days indicates fast PLFA turnover and suggests that tree-derived $C$ is the major $C$ source for ECM fungi in beech soil. Ash mycorrhizal fungi 
replaced only $10 \%$ of their fatty acid $\mathrm{C}$ by tree-derived $\mathrm{C}$ during the same period. None of the other microbial groups reached a similarly high $\mathrm{C}$ replacement in such a short time as these fungal groups. This underlines that the direct $\mathrm{C}$ allocation via mycorrhizal symbioses dominates the nutrition of these fungal groups.

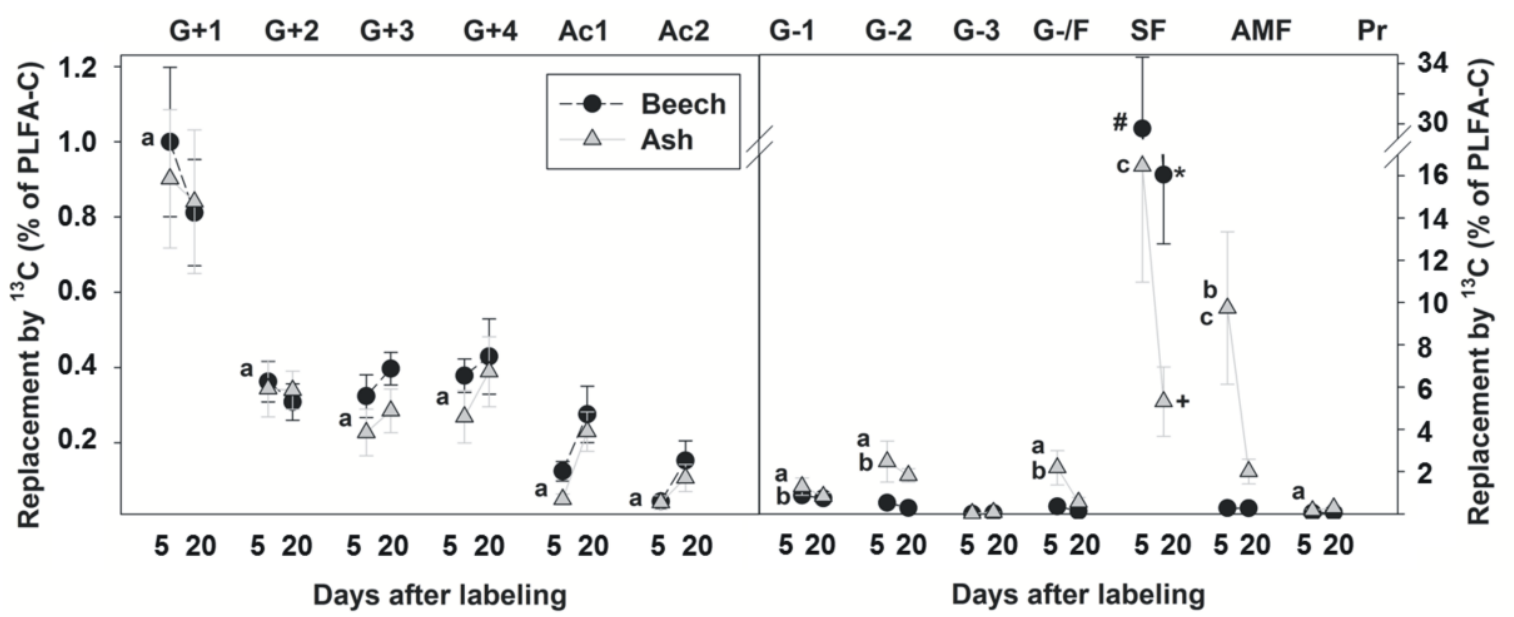

Figure 2.2-4: ${ }^{13} \mathrm{C}$ replacement (\% of PLFA-C) of microbial PLFAs in ash (grey triangle) and beech soil (black circle). Error bars show SEM $(N=10)$; symbols indicate significant differences to all other microbial groups in beech (*) and ash (+) 20 days after labeling and in beech (\#) 5 days after ${ }^{13} \mathrm{C}$ labeling $(p<0.05)$. Lower case letters $(a, b, c)$ indicate significant differences between microbial groups in ash 5 days after ${ }^{13} \mathrm{C}$ labeling $(p<$ 0.05). 


\subsubsection{Discussion}

Forest trees compete for light and soil resources, but the paths and amounts of the photosynthetically fixed $\mathrm{C}$ below the ground are little understood.

\subsubsection{C allocation within the plant-soil system as affected by tree species}

Much attention has been given in the last decade to belowground $C$ and the related soil processes under temperate tree species [9, 22, 41, 42]. Here, we quantified the link between canopy $\mathrm{C}$ assimilation and belowground processes by ${ }^{13} \mathrm{C}$ labeling and tracing the flux of $C$ into the soil and into microbial groups. Beech assimilated $21 \%$ and ash $30 \%$ of the applied ${ }^{13} \mathrm{CO}_{2}$ in all plant compartments 5 days after labeling. A field ${ }^{13} \mathrm{CO}_{2}$ labeling experiment with 3-4-m-tall beech trees assimilated $20 \%$ but ash trees only $9 \%$ of the applied ${ }^{13} \mathrm{CO}_{2}$ into plant compartments after a 5-h labeling period [9]. The difference in the initial ${ }^{13} \mathrm{CO}_{2}$ uptake between those experiments could be the labeling duration, reflecting the more rapid photosynthate transport in beech as compared to ash.

Tree size and age may also affect $\mathrm{CO}_{2}$ uptake and distribution [9]. The 1-m-high ash trees have only half of the leaf biomass of beech but twice the specific leaf area. This might explain the $30 \%$ higher incorporation of the applied ${ }^{13} \mathrm{C}$ into ash as compared to beech. The fact that beech initially allocated twice as much of the assimilated ${ }^{13} \mathrm{C}$ into the stem than ash supports the results of Sommer et al. [9]. Beech has $25 \%$ less root biomass $(<5$ $\mathrm{mm}$ ) in $0-20 \mathrm{~cm}$ depth than ash [24, 43]. Ash also has more fine roots and a more vigorous root growth [24, 41]. All these differences in root morphology and biomass help explain why beech roots incorporated only one fourth of the assimilated ${ }^{13} \mathrm{C}$ as compared to ash roots. The relative ${ }^{13} \mathrm{C}$ allocation into roots was significantly higher in ash than in beech 5 days after the labeling in a field experiment [9]. Evidently, ash has a higher root biomass than beech and preferentially invests the assimilated ${ }^{13} \mathrm{C}$ into roots, at least partially explaining its higher rhizodeposition (Figure 2.2-1).

\subsubsection{Microbial community structure}

The microbial fatty acids (Table 2.2-2) were generally similar in soil under beech and ash, as well as between 5 and 20 days after labeling. Beech, however, was associated with less Gram negative bacteria and fungi. Prokaryote microorganisms suffer from the presence of beech roots due to low pH (Figure 2.2-2) [41]. Consequently, the ratio of fungal-to-bacterial biomass increased in the soil under beech [41] and our study confirms 
this: the fungal-to-bacterial ratio was higher under beech than under ash (Figure 2.2-2). Nonetheless, such an increase in fungal abundance is attributable not only to the lower $\mathrm{pH}$, but also because 18:2w6.9 is representative for saprotrophic and furthermore ECM fungi, which only are associated with beech.

Figure 2.2-2 illustrates that similar and rather low amounts of actinomycete fatty acids (Ac1, Ac2) were present in soil of both trees. This indicates that actinomycetes depend less on rhizodeposits than other microorganisms. Actinomycetes can degrade complex organic polymers and are positioned late in the microbial reaction chain [44]. Accordingly, they might not compete well for the large amount of easily degradable SOM initially released from decaying roots [45]. The significant increase in the ${ }^{13} \mathrm{C}$ incorporation in the PLFA of actinomycetes over time might therefore also be linked to the decreased ${ }^{13} \mathrm{C}$ enrichment in fungi and might even reflect $a{ }^{13} \mathrm{C}$ flow from fungi to Actinomycetes from day 5 to 20 . The more abundant protozoa/ soil fauna in ash soil also may indicate a more intensive grazing.

Thus, microbial community structure in forest soil seems to be mainly influenced by soil properties, not directly by tree species. Although community structure was not significantly affected by tree species, there were profound differences in rhizodeposit incorporation into individual microbial groups.

\subsubsection{3}

Incorporation and replacement of root $C$ into the microbial community

The microbial group SF (18:2w6.9) incorporated most ${ }^{13} \mathrm{C}$ under beech, and only a minor fraction of the root-derived ${ }^{13} \mathrm{C}$ was transferred into bacteria. AMF had no enrichment under beech because its roots are associated with ECM, whereas ash roots are associated with arbuscular mycorrhiza [24]. The ${ }^{13} \mathrm{C}$ signature of the fungal biomarker (18:2w6.9) could be influenced by an additional ${ }^{13} \mathrm{C}$ signal derived from linoleic acid from root hairs [46]. Furthermore, the pool size of fungal-derived linoleic acid is sufficiently high to use it as biomarker even if plant roots are much larger (but have a lower surface areato-volume ratio) than fungal hyphae [40]. Therefore, the contribution of root tissue to the soil PLFA pool is relatively small and the $18: 2 \omega 6.9{ }^{13} \mathrm{C}$ enrichment presumably mainly reflects ${ }^{13} \mathrm{C}$ incorporation into ectomycorrhizal fungi. This may explain why the microbial group SF, which includes saprotrophic fungi and ECM fungi in beech soil, had a much higher replacement of their PLFA-C by ${ }^{13} \mathrm{C}$ than all other microbial groups.

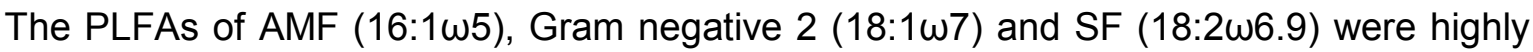
${ }^{13} \mathrm{C}$ enriched in ash and incorporated more ${ }^{13} \mathrm{C}$ than beech. We are aware, that the 16:1 155 marker is not specific for AMF and especially in agroecosystems frequently Gram negative derived [34, 47]. However, in this fungal-dominated soil, a clear difference in the 
dynamic of ${ }^{13} \mathrm{C}$ replacement can be observed between the specific Gram negative markers and the 16:1 $1 \omega 5$ - which has an extremely high enrichment 5 days after labeling that significantly decreases to day 20 . This suggests that $16: 1 \omega 5$ might be derived from a microbial group with a different turnover than the Gram negatives and thus more likely represents the AMF. AM fungi release plant-fixed ${ }^{13} \mathrm{C}$ from their mycelium to bacterial and fungal populations in the (myco-)rhizosphere [48]. Therefore, the ${ }^{13} \mathrm{C}$ enrichment in the Gram negative 2 and SF under ash might be due to direct uptake of $C$ released from the roots by saprotrophic fungi and bacteria. Alternatively, it might be an indirect path via AMF distributing $C$ in the myco-rhizosphere. Trees may interact in more complex ways e.g. over myco-rhizosphere, including substantial C exchange, although competition for resources is commonly considered to be the dominant tree-to-tree interaction in forests [49].

These results support the finding of Frostegard and Baath [50] and Zelles [14] and indicate that the 18:2w6.9 biomarker is not specific for ectomycorrhiza and also includes saprotrophic fungi as indicated by ${ }^{13} \mathrm{C}$ incorporation in ash soil. This could also be attributed to the low content of these fatty acids in AMF hyphae containing 18:2w6.9 and taking up rhizodeposit ${ }^{13} \mathrm{C}$. However, 18:2w6.9 can also be plant-derived but it is rather unlikely that amounts and enrichments in the membranes of beech and ash cells are strongly deviating. The highly significant difference in ${ }^{13} \mathrm{C}$ incorporation in beech and ash soil consequently is not dominated by plant origin but more likely is due to an ecophysiological difference between the tree species, such as mycorrhization. Furthermore, the 20:0 fatty acid, an unspecific-eucaryotic fatty acid, not only has low amounts suggesting low contamination of soil samples by root cells, but also was less enriched in ${ }^{13} \mathrm{C}$ by factor of 100 as compared to $18: 2 \omega 6.9$ suggesting that even if eucayotic cells are co-extracted their contribution to the ${ }^{13} \mathrm{C}$ enrichment is negligible. Generally, eukaryotic groups such as fungi cannot take up as much low molecular weight $C$ from soil solution as do prokaryotes because the turnover of the larger, more complex biomass of eukaryotes is slower than that of prokaryotes [51-53]. Under both tree species, the ${ }^{13} \mathrm{C}$ incorporation into mycorrhizal fungal PLFA decreased from day 5 to day 20 . This indicates that root-derived $C$ is rapidly incorporated into mycorrhizal hyphae and that the incorporated $C$ is turned over fast, at least in their membranes. SF and the G-/F group decreased by more than half from day 5 to 20 after labeling. As this ${ }^{13} \mathrm{C}$ decrease is similar to the ${ }^{13} \mathrm{C}$ decrease in AMF, the $18: 1 \omega 9$ fatty acid is probably at least partially also indicative for mycorrhizal fungi. Overall, the results suggest that PLFA analysis is a valuable tool to differentiate $C$ fluxes from trees to different mycorrhiza types.

Although Gram negatives take up root exudates fast and show a rapid turnover [51], they do not exchange their biomass (and thus their PLFA-C) as rapidly as mycorrhiza. None of 
the other microbial groups reached a similarly high and fast $\mathrm{C}$ replacement as the fungal groups. Therefore, the direct $\mathrm{C}$ flux into mycorrhiza is highly efficient and dominates the $\mathrm{C}$ nutrition of these fungal groups. Gram negatives are less relevant in ${ }^{13} \mathrm{C}$ uptake than mycorrhizal groups (Figure 2.2-3), but more relevant than most Gram positive groups. The ${ }^{13} \mathrm{C}$ incorporation into Gram negatives, SF and Pr was higher by as much as a factor of 10 than into Gram positives and Actinomycetes. The ${ }^{13} \mathrm{C}$ incorporation and enrichment did not differ for most Gram positives (including Actinomycetes) between ash and beech soil. Actinomycetes are a subgroup of Gram positives, and some studies suggest that they incorporate less $\mathrm{C}$ from dissolved $\mathrm{C}$ sources than free-living prokaryotic Gram positives [54]. Our results support this interpretation and suggest that most of the $C$ taken up by prokaryotic groups is provided as soluble root exudates by the trees. Gram positives have been suggested to mainly rely on old soil organic matter and complex compounds [8]. Accordingly, uptake of $\mathrm{C}$ from more complex rhizodeposits may explain the significant increase from day 5 to 20 after labeling of the ${ }^{13} \mathrm{C}$ incorporation into the PLFA of the Actinomycetes 1 in beech and ash soil.

Amino acid labeling in soil revealed Gram negative prokaryotes with the highest ${ }^{13} \mathrm{C}$ incorporation indicating that Gram negatives react fast to low molecular weight organic substances (LMWOS) [51]. In beech soil Gram negatives incorporated almost no ${ }^{13} \mathrm{C}$, but in ash soil incorporation of ${ }^{13} \mathrm{C}$ into Gram negative 2 was the highest of all microbial groups 20 days after labeling. This suggests that ash released higher amounts of LMWOS than beech.

A one-order-of-magnitude-higher incorporation of ${ }^{13} \mathrm{C}$ into the ectomycorrhizal partner of beech as compared to ash suggests that direct $\mathrm{C}$ allocation into mycorrhizal fungi is reduced in ash. However, most prokaryotic groups show equal or higher ${ }^{13} \mathrm{C}$ incorporation in ash than in beech maybe due to higher exudate release of ash feeding freely associated rhizomicrobial community members. We detected very low ${ }^{13} \mathrm{C}$ incorporation into $\mathrm{Pr}$ in ash and almost none in beech soil (Figure 2.2-3). The higher incorporation in ash soil indicates higher ${ }^{13} \mathrm{C}$ fluxes through soil food webs under this tree species [41], which is consequently likely to be derived from the prokaryotic groups serving as main $\mathrm{C}$ source for protozoa. This grazing of prokaryotes by protozoa is also a very likely explanation for the higher ${ }^{13} \mathrm{C}$ turnover in prokaryotic PLFAs under ash versus beech Overall, the results suggest that $\mathrm{C}$ cycling in microbial food webs is faster under ash than beech, where higher ${ }^{13} \mathrm{C}$ fluxes pass via the bacterial versus the fungal branch of the soil food web. However, systematic patterns and processes underlying variations in the composition of fatty acids and their ${ }^{13} \mathrm{C} /{ }^{12} \mathrm{C}$ ratio are under discussion as many markers, especially the protozoan one, are not absolutely specific $[40,55]$. So, final conclusions 
must be expressed with precaution and should be complemented by direct measurement of $\mathrm{C}$ and $\mathrm{N}$ fluxes into higher trophic level organisms [56, 57]. 


\subsubsection{Conclusions}

Our results highlight the importance of microbial communities and especially mycorrhizal communities for belowground $\mathrm{C}$ fluxes. The microbial community structure was similar but the $\mathrm{C}$ utilization differed in many respects between microbial groups in beech and ash soil. The higher belowground $\mathrm{C}$ allocation by ash affects the ${ }^{13} \mathrm{C}$ incorporation and replacement in various microbial groups. SF under beech incorporated the most ${ }^{13} \mathrm{C}$ with the incorporation decreasing from day 5 to 20 . This decrease in ${ }^{13} \mathrm{C}$ incorporation also occurred in ash, but ash also incorporated much of its assimilated ${ }^{13} \mathrm{C}$ in AMF and Gram negative 2 bacteria. LMWOS-adapted groups, like Gram negatives, take up more ${ }^{13} \mathrm{C}$ in ash than in beech soil. This is because such groups have a fast cellular turnover and therefore more rapidly release ${ }^{13} \mathrm{C}$ from their cells. Some of this released ${ }^{13} \mathrm{C}$ is incorporated into higher trophic levels such as protozoa and soil fauna. The results suggest that combining tree species with different root, rhizodeposition and mycorrhiza types will increase ecological functions and improve the resilience of forest ecosystems which is of increasing importance in face of global change. 


\subsubsection{Acknowledgements}

We wish to thank A. Meyer, S. Enzmann and I. Ostermeyer as technical staff for their help and also R. Langel and L. Szwec for their support with the isotope analyses. The Labor für Radioisotope, especially B. Kopka, provided important technical support. This work was funded by the German Research Foundation (DFG KU-1086/13-2 and NST 186/10061/P). 


\subsubsection{References}

[1] FAO, Global Forest Resources Assessment 2005. Progress towards sustainable forest management, FAO Forestry Paper, 147 (2006) 11-36.

[2] J. Esperschütz, A. Gattinger, F. Bügger, H. Lang, J.C. Munch, M. Schloter, J.B. Winkler, A continuous labelling approach to recover photosynthetically fixed carbon in plant tissue and rhizosphere organisms of young beech trees (Fagus sy/vatica L.) using ${ }^{13} \mathrm{C}$ depleted $\mathrm{CO}_{2}$, Plant and Soil, 323 (2009) 21-29.

[3] J.H.v. Thünen-Institut, Dritte Bundeswaldinventur, in, Braunschweig, 2012, pp. https://bwi.info/start.aspx.

[4] H. Rennenberg, M. Dannenmann, A. Gessler, J. Kreuzwieser, J. Simon, H. Papen, Nitrogen balance in forest soils: nutritional limitation of plants under climate change stresses, Plant Biology, 11 (2009) 4-23.

[5] M. Schön, Forstwirtschaft und Gefäßpflanzen der roten Liste: Arten - Standorte, Herbert Utz Verlag GmbH, München, 1998.

[6] T.R. Cavagnaro, L.E. Jackson, J. Six, H. Ferris, S. Goyal, D. Asami, K.M. Scow, Arbuscular mycorrhizas, microbial communities, nutrient availability, and soil aggregates in organic tomato production, Plant and Soil, 282 (2006) 209-225.

[7] P. Marschner, K. Baumann, Changes in bacterial community structure induced by mycorrhizal colonisation in split- root maize, Plant and Soil, 251 (2003) 279-289.

[8] M. Scherer-Lorenzen, C. Körner, E.D. Schulze, The functional significance of forest diversity: a synthesis, in: Forest Diversity and Function: Temperate and Boreal Systems, Springer, Berlin, Heidelberg, New York, 2005, pp. 377-389.

[9] J. Sommer, M.A. Dippold, H. Flessa, Y. Kuzyakov, Allocation and dynamics of C and N within plant-soil system of ash and beech, Journal of Plant Nutrition and Soil Science, 179 (2016) 376-387.

[10] J.-A. Subke, H.W. Vallack, T. Magnusson, S.G. Keel, D.B. Metcalfe, P. Högberg, P. Ineson, Short-term dynamics of abiotic and biotic soil ${ }^{13} \mathrm{CO}_{2}$ effluxes after in situ ${ }^{13} \mathrm{CO}_{2}$ pulse labelling of a boreal pine forest, New Phytologist, 183 (2009) 349-357.

[11] Y. Kuzyakov, O. Gavrichkova, REVIEW: Time lag between photosynthesis and carbon dioxide efflux from soil: a review of mechanisms and controls, Global Change Biology, 16 (2010) 3386-3406.

[12] J. Cebrian, Patterns in the fate of production in plant communities, American Naturalist, 154 (1999) 449-468.

[13] B.W. Hütsch, J. Augustin, W. Merbach, Plant rhizodeposition-an important source for carbon turnover in soils, Journal Plant Nutrition and Soil Science, 165 (2002) 397-407.

[14] L. Zelles, Fatty acid patterns of phospholipids and lipopolysaccharides in the characterisation of microbial communities in soil: a review, Biology and Fertility of Soils, 29 (1999) 111-129.

[15] S.E. Leckie, C.E. Prescott, S.J. Grayston, J.D. Neufeld, W.W. Mohn, Comparison of chloroform fumigation-extraction, phospholipid fatty acid, and DNA methods to determine microbial biomass in forest humus, Soil Biol. Biochem., 36 (2004) 529-532.

[16] A. Guckland, H. Flessa, J. Prenzel, Controls of temporal and spatial variability of methane uptake in soils of a temperate deciduous forest with different abundance of European beech (Fagus sylvatica L.), Soil Biol. Biochem., 41 (2009) 1659-1667. 
[17] P.M. Schleuss, F. Heitkamp, C. Leuschner, A.C. Fender, H.F. Jungkunst, Higher subsoil carbon storage in species-rich than species-poor temperate forests,

Environmental Research Letters, 9 (2014).

[18] A. Guckland, M. Jacob, H. Flessa, F.M. Thomas, C. Leuschner, Acidity, nutrient stocks, and organic-matter content in soils of a temperate deciduous forest with different abundance of European beech (Fagus sylvatica L.), J. Plant Nutr. Soil Sci.-Z.

Pflanzenernahr. Bodenkd., 172 (2009) 500-511.

[19] C. Langenbruch, M. Helfrich, H. Flessa, Effects of beech (Fagus sylvatica), ash (Fraxinus excelsior) and lime (Tilia spec.) on soil chemical properties in a mixed deciduous forest, Plant and Soil, 352 (2012) 389-403.

[20] M. Jacob, K. Viedenz, A. Polle, F.M. Thomas, Leaf litter decomposition in temperate deciduous forest stands with a decreasing fraction of beech (Fagus sylvatica), Oecologia, 164 (2010) 1083-1094.

[21] A.M. Kooijman, E. Cammeraat, Biological control of beech and hornbeam affects species richness via changes in the organic layer, $\mathrm{pH}$ and soil moisture characteristics, Funct. Ecol., 24 (2010) 469-477.

[22] L. Vesterdal, I.K. Schmidt, I. Callesen, L.O. Nilsson, P. Gundersen, Carbon and nitrogen in forest floor and mineral soil under six common European tree species, Forest Ecology and Management, 255 (2008) 35-48.

[23] M. Jacob, N. Weland, C. Platner, M. Schaefer, C. Leuschner, F.M. Thomas, Nutrient release from decomposing leaf litter of temperate deciduous forest trees along a gradient of increasing tree species diversity, Soil Biol. Biochem., 41 (2009) 2122-2130.

[24] C. Meinen, D. Hertel, C. Leuschner, Biomass and morphology of fine roots in temperate broad-leaved forests differing in tree species diversity: is there evidence of below-ground overyielding?, Oecologia, 161 (2009) 99-111.

[25] L.B. Shi, M. Guttenberger, I. Kottke, R. Hampp, The effect of drought on mycorrhizas of beech (Fagus sylvatica L.): changes in community structure, and the content of carbohydrates and nitrogen storage bodies of the fungi, Mycorrhiza, 12 (2002) 303-311.

[26] P. Schütt, H. Weisberger, H.J. Schuck, U.M. Lang, B. Stimm, A. Roloff, Enzyklopädie der Laubbäume, Nikol Verlagsgesellschaft mbH \& Co KG, Hamburg, 2006.

[27] S. Scheu, G. Poser, The soil macrofauna (Diplopoda, Isopoda, Lumbricidae and Chilopoda) near tree trunks in a beechwood on limestone: indications for stemflow induced changes in community structure, Applied Soil Ecology, (1996) 115-125.

[28] M. Maraun, J. Alphei, P. Beste, M. Bonkowski, R. Buryn, S. Migge, M. Peter, M. Schaefer, S. Scheu, Indirect effects of carbon and nutrient amendments on the soil mesoand microfauna of a beechwood, Biology and Fertility of Soils, 34 (2001) 222-229.

[29] S. Scheu, M. Falca, The soil food web of two beech forests (Fagus sylvatica) of contrasting humus type: stable isotope analysis of a macro- and a mesofauna-dominated community, Oecologia, 123 (2000) 285-296.

[30] L. Ebrecht, Vegetation, Standortverhältnisse und Ausbreitungsbiologie von Pflanzen auf Rückegassen und Waldwegen im Göttinger Wald und im Solling, in: Fakultät für Forstwissenschaften u. Waldökologie, Cuvillier Verlag Göttingen, 2005.

[31] J. Pausch, J. Tian, M. Riederer, Y. Kuzyakov, Estimation of rhizodeposition at field scale: upscaling of a ${ }^{14} \mathrm{C}$ labeling study, Plant and Soil, 364 (2013) 273-285.

[32] M. Riederer, J. Pausch, Y. Kuzyakov, T. Foken, Partitioning NEE for absolute C input into various ecosystem pools by combining results from eddy-covariance, atmospheric flux partitioning and ${ }^{13} \mathrm{CO}_{2}$ pulse labeling, Plant and Soil, 390 (2015) 61-76. 
[33] Å. Frostegård, A. Tunlid, E. Bååth, Microbial biomass measured as total lipid phosphate in soils of different organic content, Journal of Microbiological Methods, 14 (1991) 151-163.

[34] A. Gunina, M.A. Dippold, B. Glaser, Y. Kuzyakov, Fate of low molecular weight organic substances in an arable soil: From microbial uptake to utilisation and stabilisation, Soil Biol. Biochem., 77 (2014) 304-313.

[35] D.R. Knapp, Handbook of Analytical Derivatization Reagents, wiley, 1979.

[36] P.J. Gearing, J.N. Gearing, J.T. Maughan, C.A. Oviatt, Isotopic distribution of carbon from sewage sludge and eutrophication in the sediments and food web of Estuarine ecosystems, Environmental Science \& Technology, 25 (1991) 295-301.

[37] M.A. Dippold, Y. Kuzyakov, Direct incorporation of fatty acids into microbial phospholipids in soils: Position-specific labeling tells the story, Geochimica et Cosmochimica Acta, 174 (2016) 211-221.

[38] W. Gottwald, Statistik für Anwender, WILEY-VCH Verlag GmbH, 2000.

[39] L. Zelles, Q.Y. Bai, R. Rackwitz, D. Chadwick, F. Beese, Determination of phospholipid-derived and lipopolysaccharide-derived fatty acids as an estimate of microbial biomass and community structures in soils, Biology and Fertility of Soils, 19 ( 1995) 115-123.

[40] L. Ruess, P.M. Chamberlain, The fat that matters: Soil food web analysis using fatty acids and their carbon stable isotope signature, Soil Biol. Biochem., 42 (2010) 1898-1910.

[41] S. Cesarz, A.C. Fender, F. Beyer, K. Valtanen, B. Pfeiffer, D. Gansert, D. Hertel, A. Polle, R. Daniel, C. Leuschner, S. Scheu, Roots from beech (Fagus sylvatica L.) and ash (Fraxinus excelsior L.) differentially affect soil microorganisms and carbon dynamics, Soil Biology and Biochemistry, 61 (2013) 23-32.

[42] I. Callesen, I. Stupak, P. Georgiadis, V.K. Johannsen, H.S. Østergaard, L. Vesterdal, Soil carbon stock change in the forests of Denmark between 1990 and 2008, Geoderma Regional, 5 (2015) 169-180.

[43] S. Oostra, H. Majdi, M. Olsson, Impact of tree species on soil carbon stocks and soil acidity in southern Sweden, Scandinavian Journal of Forest Research, 21 (2006) 364-371.

[44] J. Lacey, Actinomycetes in soils, compost and fodders, Academic Press, London, 1973.

[45] L. Thirup, K. Johnsen, V. Torsvik, N.H. Spliid, C.S. Jacobsen, Effects of fenpropimorph on bacteria and fungi during decomposition of barley roots, Soil Biology and Biochemistry, 33 (2001) 1517-1524.

[46] J. Pausch, S. Kramer, A. Scharroba, N. Scheunemann, O. Butenschoen, E. Kandeler, S. Marhan, M. Riederer, S. Scheu, Y. Kuzyakov, L. Ruess, Small but active - pool size does not matter for carbon incorporation in below-ground food webs, Funct. Ecol., (2016) 479-489.

[47] P.A. Olsson, E. Baath, I. Jakobsen, B. Soderstrom, The use of phospholipid and neutral lipid fatty-acids to estimate biomass of arbuscular mycorrhizal fungi in soil, Mycol. Res., 99 (1995) 623-629.

[48] B. Drigo, A.S. Pijl, H. Duyts, A. Kielak, H.A. Gamper, M.J. Houtekamer, H.T.S. Boschker, P.L.E. Bodelier, A.S. Whiteley, J.A. van Veen, G.A. Kowalchuk, Shifting carbon flow from roots into associated microbial communities in response to elevated atmospheric $\mathrm{CO}_{2}$, Proceedings of the National Academy of Sciences of the United States of America, 107 (2010) 10938-10942.

[49] T. Klein, R.T.W. Siegwolf, C. Körner, Belowground carbon trade among tall trees in a temperate forest, Science, 352 (2016) 342-344. 
[50] A. Frostegard, E. Baath, The use of phospholipid fatty acid analysis to estimate bacterial and fungal biomass in soil, Biology and Fertility of Soils, 22 (1996) 59-65.

[51] C. Apostel, M. Dippold, B. Glaser, Y. Kuzyakov, Biochemical pathways of amino acids in soil: Assessment by position-specific labeling and ${ }^{13} \mathrm{C}-\mathrm{PLFA}$ analysis, Soil Biology and Biochemistry, 67 (2013) 31-40.

[52] E. Baath, Growth rates of bacterial communities in soils at varying $\mathrm{pH}$ : A comparison of the thymidine and leucine incorporation techniques, Microbial Ecology, 36 (1998) 316327.

[53] J. Rousk, E. Bååth, Fungal biomass production and turnover in soil estimated using the acetate-in-ergosterol technique, Soil Biology and Biochemistry, 39 (2007) 2173-2177.

[54] C. Apostel, M. Dippold, Y. Kuzyakov, Biochemistry of hexose and pentose transformations in soil analyzed by position-specific labeling and ${ }^{13} \mathrm{C}-\mathrm{PLFA}$, Soil Biology and Biochemistry, 80 (2015) 199-208.

[55] A. Frostegard, A. Tunlid, E. Baath, Use and misuse of PLFA measurements in soils, Soil Biol. Biochem., 43 (2011) 1621-1625.

[56] M.M. Pollierer, J. Dyckmans, S. Scheu, D. Haubert, Carbon flux through fungi and bacteria into the forest soil animal food web as indicated by compound-specific ${ }^{13} \mathrm{C}$ fatty acid analysis, Funct. Ecol., 26 (2012) 978-990.

[57] O. Ferlian, B. Klarner, A.E. Langeneckert, S. Scheu, Trophic niche differentiation and utilisation of food resources in collembolans based on complementary analyses of fatty acids and stable isotopes, Soil Biol. Biochem., 82 (2015) 28-35. 


\title{
2.2.8 Supplementary material
}

\author{
Supplementary material for
}

\section{The tree species matters: \\ Belowground carbon input and utilization \\ in the myco-rhizosphere}

\author{
Submitted to European Journal of Soil Biology \\ JANINE SOMMER ${ }^{1}$, MICHAELA A. DIPPOLD ${ }^{3}$, SARAH L. ZIEGER ${ }^{2}$, ANIKA \\ HANDKE ${ }^{1}$, STEFAN SCHEU ${ }^{2}$, YAKOV KUZYAKOV ${ }^{1,3}$
}

${ }^{1}$ Georg-August-University Göttingen, Soil Science of Temperate Ecosystems, Büsgenweg 2, 37077 Göttingen, Germany

${ }^{2}$ Georg-August-University Göttingen, J.F. Blumenbach Institute of Zoology and Anthropology, Berliner Str. 28, 37073 Göttingen, Germany

${ }^{3}$ Georg-August-University Göttingen, Agricultural Soil Science, Büsgenweg 2, 37077 Göttingen, Germany

Email of the corresponding author*: sommer.janine@yahoo.de 
Table 2.2-3: Fatty acids in the external standard

\begin{tabular}{|c|c|c|c|c|}
\hline FA-type & Name & Common name & Abbreviation & $\begin{array}{c}\text { Retention time } \\
(\mathbf{s})^{\star}\end{array}$ \\
\hline \multirow{6}{*}{ Saturated } & Tetradecanoic acid & Myristic acid & 14:0 & 1530 \\
\hline & Pentadecanoic acid & - & 15:0 & 1778 \\
\hline & Hexadecanoic acid & Palmitic acid & $16: 0$ & 2120 \\
\hline & Heptadecanoic acid & Margaric acid & $17: 0$ & 2593 \\
\hline & Octadecanioc acid & Stearic acid & $18: 0$ & 3179 \\
\hline & Eicosanoic acid & Arachidic acid & 20:0 & 4384 \\
\hline \multirow{8}{*}{$\begin{array}{l}\text { Branched } \\
\text { chain }\end{array}$} & 11-Methyltridecanoic acid & Anteisomyristic acid & a14:0 & 1472 \\
\hline & 12-Methyltridecanoic acid & Isomyristic acid & i14:0 & 1458 \\
\hline & 12-Methyltetradecanoic acid & 12-Methylmyristic acid & a15:0 & 1699 \\
\hline & 13-Methyltetradecanoic acid & 13-Methylmyristic acid & i15:0 & 1677 \\
\hline & 13-Methylpentadecanoic acid & Anteisopalmitic acid & a16:0 & 2011 \\
\hline & 14-Methylpentadecanoic acid & Isopalmitic acid & i16:0 & 1982 \\
\hline & 14-Methylhexadecanoic acid & 14-Methylpalmitic acid & a17:0 & 2445 \\
\hline & 15-Methylhexadecan acid & 15-Methylpalmitic acid & $i 17: 0$ & 2404 \\
\hline \multirow{2}{*}{$\begin{array}{l}\text { Cyclo- } \\
\text { propane }\end{array}$} & $\begin{array}{c}\text { cis-9,10- } \\
\text { Methylenhexadecanioc } \\
\text { acid }\end{array}$ & $\begin{array}{l}\text { cis-9,10-Methylpalmitic } \\
\text { acid }\end{array}$ & cy17:0 & 2501 \\
\hline & $\begin{array}{c}\text { cis-9,10- } \\
\text { Methylenoctadecanoic } \\
\text { acid }\end{array}$ & Dihydrosterculic acid & cy19:0 & 3690 \\
\hline \multirow{2}{*}{ Methylated } & 10-Methylhexadecanoic acid & 10-Methylpalmitic acid & 10Me16:0 & 2306 \\
\hline & 10-Methyloctadecanoic acid & Tuberculostearic acid & 10Me18:0 & 3429 \\
\hline \multirow{6}{*}{$\begin{array}{l}\text { Mono- } \\
\text { unsaturated }\end{array}$} & 9-Tetradecaeoic acid & Myristoleic acid & $14: 1 w 5 c$ & 1502 \\
\hline & cis-11-Hexadecenoic acid & - & $16: 1 w 5 c$ & 2071 \\
\hline & cis-9-Hexadecenoic acid & Palmitoleic acid & $16: 1 w 7 c$ & 2035 \\
\hline & cis-Octadecenoic acid & Cis-Vaccenic acid & $18: 1 w 7 c$ & 3036 \\
\hline & cis-9-Octadecenoic acid & Oleic acid & $18: 1 w 9 c$ & 3001 \\
\hline & 11-Eicosenoic acid & Eicosenoic acid & $20: 1 w 9 c$ & 4220 \\
\hline \multirow{3}{*}{$\begin{array}{l}\text { Poly- } \\
\text { unsaturated }\end{array}$} & $\begin{array}{c}\text { cis,cis-9,12-Octadecadienoic } \\
\text { acid }\end{array}$ & Linoleic acid & $18: 2 w 6,9$ & 2950 \\
\hline & 6,9,12-Octadecatrienoic acid & g-linolenic acid & $18: 3 w 6,9,12$ & 2981 \\
\hline & $\begin{array}{c}\text { cis,cis,cis,cis-5,8,11,14- } \\
\text { Eicosatetraenoic acid }\end{array}$ & Arachidonic acid & $20: 4 w 6$ & 3931 \\
\hline
\end{tabular}

*for $45 \mathrm{~m} \pm 0.5 \mathrm{~m}$ column lengths, deviations of $\pm 15 \mathrm{~s}$ possible 


\section{Study 3}

\subsection{Mechanisms of phosphate acquisition by mycorrhiza}

JANINE SOMMER ${ }^{1 *}$, BELINDA DAVIS ${ }^{2,3}$, WEI-HAN LIM², MATTHIAS GUBE ${ }^{1}$, YAKOV KUZYAKOV ${ }^{1}$, KINGSLEY W: DIXON ${ }^{2,3}$

Submitted to Mycological Progress

${ }^{1}$ Soil Science of Temperate Ecosystems, Georg-August-Universität Göttingen, Göttingen, NI 37077, Germany

${ }^{2}$ School of Plant Biology, University of Western Australia, Crawley, WA 6009, Australia ${ }^{3}$ Botanic Gardens and Parks Authority, West Perth, WA 6005, Australia

"corresponding author

Department of Soil Science of Temperate Ecosystems, Georg-August-University Göttingen, 37077 Göttingen, Germany

Phone: + 49(0)157 $73857055 \quad$ Fax $+49(0) 551393310$

email: sommer.janine@yahoo.de 


\section{Abstract}

Mycorrhizas and their diverse phosphorus (P) acquisition mechanisms have been investigated for more than a century, with a large body of literature devoted to the major mycorrhizal types like ectomycorrhiza (ECM) and arbuscular (AM). In comparison, little is known about the nutritional partnerships at the interfaces between orchid, fungus, and soil. Unlike almost all other plants, seeds of many orchids lack germination without an appropriate endophyte. The orchid protocorm development to seedlings is also strongly limited without mycorrhizas, a feature that greatly influences their distribution and ultimately. To date research on orchid-mycorrhiza interactions have focused mainly on $C$ and $\mathrm{N}$, and only little is known for $\mathrm{P}$. This is in contrast to the fact that orchids live in some of the most phosphorus impoverished environments on earth - ancient soils in South Africa's Cape region and southwest Australia and the surprisingly large number of tropical epiphytic orchid species that utilise rock, bark or twig substrates for acquisition. Mycorrhiza are able to take up dissolved, and to mobilize sorbed, organic and mineral $\mathrm{P}$ forms from soil behind the $P$ depletion zone of the root using biochemical and biophysical strategies to increase the effectiveness and absorption surface to mobilize $P$ from the soil. Here we provide a comparative review of phosphorus acquisition, uptake and storage in the major mycorrhizal systems in plants. We focus on orchid mycorrhizas and identify the knowledge gaps that require further research if we are to advance our understanding of this, the largest family of the angiosperms.

Key-words: arbuscular mycorrhiza, ectomycorrhiza, mineral nutrient, orchid mycorrhiza, phosphorus metabolism, phosphorus transport 


\subsubsection{Introduction}

Mycorrhizal fungi occur in many soil types and a very wide range of climatic conditions from arctic tundra to desert environments and the humid tropics. Mycorrhizal fungi may function as necrotrophs and antagonists of host or non-host plants with roles that vary during the lifespan (host) of their associations (Smith and Read, 1997; Brundrett, 2004). There is a large body of literature regarding mycorrhizal symbiosis, but many knowledge gaps exist surrounding the ecophysiological benefits to both fungus and host plant. Certain soil microorganisms colonize roots of higher plants and form symbiotic relationships that benefit one or both partners. Nodulating bacteria, for example, Rhizobia in Legumes and mycorrhizal associations formed by fungi with roots and stems enables plants to acquire resources more efficiently than would happen without the fungal interactions. The uptake of $\mathrm{P}$, particularly in P-limiting environments (Lambers et al., 2008), may be a critical element of orchid-fungal interaction. Plants have developed a variety of strategies to increase $P$ uptake capacity or availability of $P$ in soil, because $P$ is one of the most difficult nutrients for plants to acquire, however the most common of these strategies worldwide is AM symbiosis (Smith et al., 2011) (Table 2.3-1). Mycorrhizal associations are broadly divided into four categories: arbuscular AM, ECM, ericoid (ERM) and orchid mycorrhiza (OM) (Tinker, 1975; Handreck, 1997; Bücking and Heyser, 2000; Lambers et al., 2008; Smith and Read, 2008) (Table 2.3-1).

Mycorrhizas are dynamic associations comprising various phylogenetic, morphological, and functional categories (Table 2.3-1). Ectomycorrhizal associations are important in many habitats but are restricted to woody and few herbaceous perennials, although they may also co-associate with other plants, including orchids (Smith and Read, 2008; Yagame et al., 2012; Yagame and Yamato, 2013). Ectomycorrhizal fungi form a dense fungal mantle around the fine roots and an intercellular hyphal "Hartig" net (Table 2.3-1). ECM fungi belong to higher Basidiomycota and Ascomycota and are septated fungi (Smith and Read, 2008; Tedersoo and Smith, 2013). Arbuscular, ericoid and orchid mycorrhiza each in their own way represent unrelated host and fungus lineages of endomycorrhizal associations with contrasting morphological and anatomical features in infected tissues in the host (Lewis, 1973; Brundrett and Abbott, 2002). Arbuscular mycorrhizal associations are endophytic, obligate symbiotic fungi that are the most widespread in the plant kingdom (Schüßler et al., 2001). 
Table 2.3-1: Summary of types of mycorrhizal associations

Ectomycorrhiza (ECM)

Arbuscular mycorrhiza (AM)

Orchid mycorrhiza (OM)
Associations of higher fungi with land plants with short lateral roots where a hyphal mantle encloses the root and a Hartig net comprising labyrinthine hyphae penetrates between root cells

Mycorrhizal association formed by glomeromycete fungi in land plants usually with arbuscules and often with vesicles

Associations where coils of hyphae (pelotons) penetrate within cells in the plant family Orchidaceae

Orchid mycorrhizal fungi are mostly Basidiomycota like Rhizoctonia, Ceratobasidium, Sebacina, Thanatephorus, Tulasnella, Waitea, and Ypsilonidium (Smith and Read, 2008). However, Ascomycete orchid symbionts have also been identified (Těšitelová et al., 2012). Within the Orchidaceae, associations with mycorrhizal fungi play a crucial role and represent the one family with more species with obligate requirements for mycorrhizal fungi than any other Angiosperm family (Rasmussen, 1995) (Figure 2.3-1). Orchids depend on fungi in the earliest stage of their development, when fungi support germination and growth of dust-like seeds that contain only minimal nutrient reserves (Figure 2.3-1) (Burgeff, 1959; Arditti and Ghani, 2000; Bidartondo et al., 2004). 
a)

Fungal derived Autotroph Partial Mycoheterotroph Mycoheterotroph nutrients

Photosynthetically derived $\mathrm{C}$
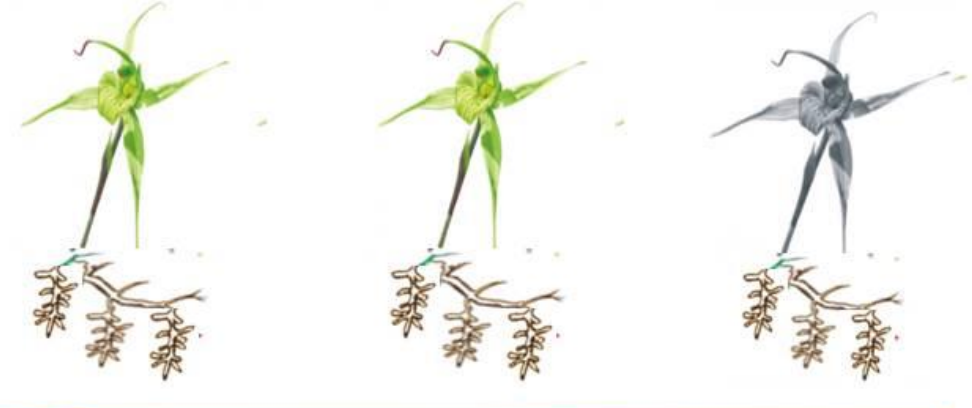

$P, C$ and $N$

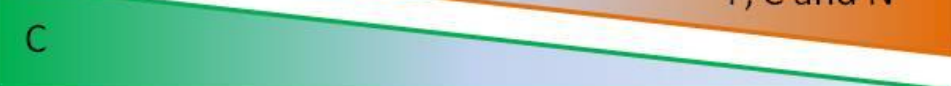

b)

Reliance on fungal derived nutrients

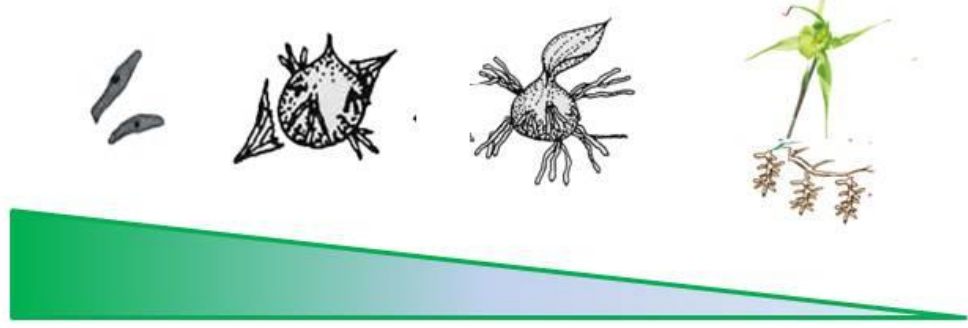

Figure 2.3-1: Nutrient uptake modes and life cycle differences in orchid mycorrhizal associations. a) The nutritional modes of orchids from complete autotrophs to mycoheterotrophs. There is an increasing reliance on fungal derived nutrients such as $P$, $C, N$ and micronutrients (brown triangle) towards non-photosynthetic mycoheterotrophs, conversely there is an increasing reliance on photosynthetically derived sources of $C$ and fungal derived sources of $P, N$ and micronutrients towards the autotrophic orchids (green triangle). b) The reliance of orchids on their fungal partners can change from mycoheterotrophic seedling to degrees of autotrophy in the adult stage.

With estimates of up to 35000 taxa, and comprising five subfamilies and 870 genera the Orchidaceae is the largest family in the plant kingdom, accounting for ca. $10 \%$ of angiosperm diversity (Atwood, 1986; Dressler, 2005). Orchids are ecologically highly successful and occur on all vegetated continents including sub-Antarctic islands (Dressler, 1993; Chase et al., 2003; Cribb et al., 2003). Temperate and tropical species of terrestrial orchids often exhibit high levels of mycorrhizal colonization in comparison to epiphytic orchids that are relatively sparsely and sporadically colonized (Benzing and Friedman, 1981). 
Leafless epiphytic orchids (e.g. Taeniophyllum Blume) have a large investment in mycorrhiza, however these orchids instead invest in chlorophyllous roots as their primary means of C uptake (Benzing et al., 1983). For nutrient acquisition, epiphytes rely on dissolved nutrients trickling down the bark of host plants. This is a feature exploited by the vast commercial 'non-mycorrhizal' production of epiphytic Phalaenopsis Blume, Dendrobium SW. and vandaceous orchids, where plants are provided nutrients through fertilizer application of inorganic N, P and trace elements (Griesbach, 2002). A feature of terrestrial orchids is the presence of so-called 'achlorophyllous' species with 210 orchid species lacking a substantial capacity for autotrophy (Merckx and Freudenstein, 2010). This mycoheterotrophic mode of nutrition results in the plant remaining reliant upon a fungal symbiont or symbionts from germination to maturity (Figure 2.3-1) (Leake, 1994; Leake et al., 2004).

Orchids, unlike most Angiosperms, are 'coarse rooted' forming only a few large roots compared to the fine root systems of more typical non-orchid herbaceous plants. For many orchids, root hairs are replaced by trichome extensions particularly in terrestrial species (Ramsay et al., 1986) or by the velamen radicum in epiphytic taxa (Benzing, 1996). However, the majority of orchids are photosynthetic at maturity and may decrease or cease dependency on their mycorrhizal partners for C (Merckx and Freudenstein, 2010). However, recent research indicates that some of the green orchids, originally considered to be completely autotrophic, also obtain substantial amounts of $\mathrm{C}$ and $\mathrm{N}$ from fungi in the adult stage (Figure 2.3-1) (Cameron et al., 2008; Sommer et al., 2012) through partial mycoheterotrophy (Leake, 1994). The fully and partially mycoheterotrophic green orchids with demonstrated fungal $\mathrm{C}$ and $\mathrm{N}$ (and possibly all other nutrients including $\mathrm{P}$ ) acquisition often grow in dense forests under light-limited conditions (Figure 2.3-1), while mature autotrophic orchids prefer more open habitats (Liebel et al., 2010). For partially mycoheterotroph species of the orchid genus Cephalanthera Rich., a significant negative relationship was found between the degree of $C$ gain from the fungal source and the micro-scale light availability (Figure 2.3-1) (Preiss et al., 2010). Only a few partially mycoheterotrophic species are found in open habitats (Liebel et al., 2010; Girlanda et al., 2011). Like many other coarse-rooted plants, most adult terrestrial orchids are likely to remain dependent upon mycorrhiza for mineral nutrient uptake, particularly $\mathrm{P}$ (Baylis, 1975; Cameron et al., 2007). Though research has revealed remarkable dependencies by the orchid on its fungal partner, comparatively little is understood about $P$ uptake and transport (Cameron et al., 2007; Smith and Read, 2008).

Here we review what is known about the $P$ nutrition of mycorrhizal symbiosis, with particular emphasis on the gaps in knowledge with regards to orchid mycorrhiza. The distribution of $P$ forms in soil, techniques used to determine $P$ levels and the uptake and 
storage of $\mathrm{P}$ in ECM, AM and OM, as well as the transport of $\mathrm{P}$ to and from the fungus are also discussed. $P$ is one of the most difficult nutrients for plants to acquire and mycorrhizal symbiosis is the most important strategy of plants to fulfill that requirement. 


\subsubsection{Phosphorus availability in soil}

The four $\mathrm{P}$ forms in soils: dissolved inorganic phosphate $(\mathrm{Pi})$, sorbed $\mathrm{Pi}$, organic $\mathrm{P}$ and mineral $\mathrm{Pi}$ will vary depending upon soil $\mathrm{pH}$ (Figure 2.3-2). The distribution of those forms of $P$ depends on various factors which include soil type, vegetation form, microbial activity and human management (Dalal, 1977; Hedley et al., 1982; Lodge et al., 1994; Robinson, 1994). The acquisition of $P$ by mycorrhizal fungi or their accompanying microorganisms may improve soil $\mathrm{P}$ availability by solubilizing mineral $\mathrm{P}$ forms, exchanging adsorbed $\mathrm{P}$ or by mineralization of organic P (Hetrick et al., 1989; Turner, 2008) (Figure 2.3-2). Phosphorus availability in habitats of epiphytic plants differs strongly from that of soil and will be dealt with later.

Very little $\mathrm{P}$ can be found in soil solution, either as free phosphate anions, soluble $\mathrm{Ca}-$ phosphate complexes, or organically coordinated complexes. Plants cover most of their $P$ requirements from the $\mathrm{Pi}$ in the soil solution (Bolan, 1991) (Figure 2.3-2). Bioturbation and preferential water flow can cause hotspots in availability of this preferred $\mathrm{P}$ source, which plants can access by root growth and root proliferation towards these hotspots. Plants forming a mycorrhizal symbiosis have the advantage of being thus able to increase the uptake of $P$ by increasing the total surface area of the symbiotic system (Figure 2.3-2). Additional advantage is provided by the presence of both fungal and plant $\mathrm{P}$ acquisition and transport systems. (Zhu et al., 2001; Cameron et al., 2007; Nagy et al., 2009; Plassard and Dell, 2010).

Mineral $\mathrm{P}$ occurs in different phosphate minerals. The anions of the phosphoric acid $\left(\mathrm{H}_{3} \mathrm{PO}_{4}\right)$ have high affinity towards $\mathrm{Ca}^{2+}, \mathrm{Al}^{3+}, \mathrm{Fe}^{3+}, \mathrm{Fe}^{2+}$ as well as nearly all bivalent cations and bind with those to form insoluble phosphates. If the $\mathrm{pH}$ in soil decreases, solubility of $\mathrm{P}$ from $\mathrm{Ca}^{2+}$ phosphate increases and conversely, with $\mathrm{Al}^{3+}$ - and $\mathrm{Fe}^{3+}$ phosphate the solubility decreases with decreasing $\mathrm{pH}$. The optimal $\mathrm{pH}$ for maximum solubility of $P$ is 5-6.5 (Blume et al., 2010). 


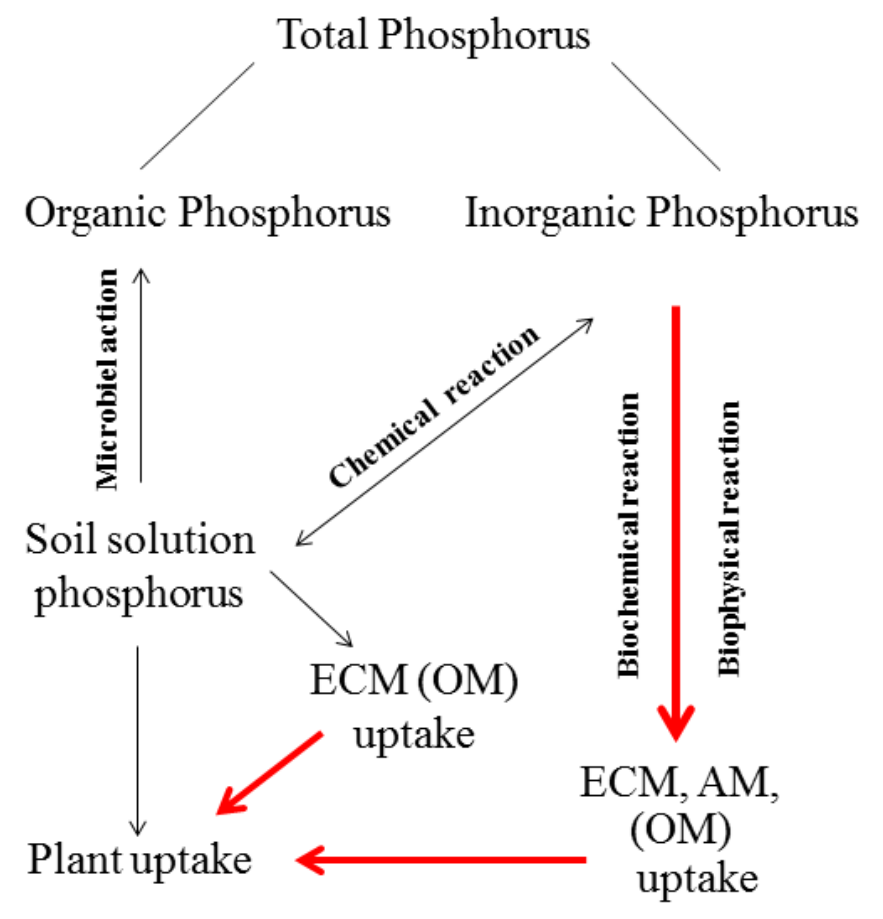

Figure 2.3-2: Phosphorus forms in soil and its pathways to the plant uptake

Phosphates can also be sorbed to the surface of $\mathrm{Fe}$ - and Al-oxides or clay minerals. This sorption effect is enhanced if the respective surface is porous, as in highly weathered soils. Mobilization of P sorbed on Fe and Al oxides and other minerals may be caused by chelation of $\mathrm{Fe}$ and $\mathrm{Al}$ through complexing agents such as siderophores and organic acids including citrate or oxalate, which in turn will lead to $P$ release in solution - a strategy used by mycorrhizal fungi to gain access to this $P$ pool (Cumming and Weinstein, 1990; Gibson and Mitchell, 2004; Tawaraya et al., 2006).

$\mathrm{P}$ dissolution by local $\mathrm{pH}$ change is employed by both plants and mycorrhizal fungi in alkaline and neutral soils, where fungal exudates such as oxalic acid decrease the local $\mathrm{pH}$ up to 2 units in the hyphal growth zone (Colotelo, 1978; Oberson and Joner, 2005; Plassard et al., 2011). Mycorrhiza have a higher affinity to phosphate ions and a lower $\mathrm{P}$ threshold value than nonmycorrhizal roots (Bolan, 1991). The small diameter of mycorrhizal hyphae also enables fungi to access smaller soil pores (Tinker, 1975; Gianinazzi-Pearson and Gianinazzi, 1983) and thus obtain minerals otherwise unavailable to plant root hairs. 
Phosphorus is also a component of soil organic matter and microbial biomass, with the most important organic form of $\mathrm{P}$ found as inositol phosphates (phytates), phospholipids, nucleic acids, phosphodiesters, phosphomonoesters, and organic polyphosphates (Turner, 2008). Organic $P$ is as such not plant available and has to be mineralized to inorganic $\mathrm{P}$ to become plant-available (Bolan, 1991; Oberson and Joner, 2005). Autolysis of microbial cells or enzymatic dephosphorylation leads to organic $\mathrm{P}$ mineralization (Cosgrove, 1977). Several microbes, including mycorrhizal fungi, are able to produce specialized phosphatases such as phosphomonoesterases, phosphodiesterases and phytases involved in the mineralization of organic $P$ (Colotelo, 1978; Oberson and Joner, 2005; Cairney, 2011), splitting the P-ester-bond and making the P plant available (Blume et al., 2010). While microbial action is generally considered the major driver of organic $P$ mineralization (Spohn and Kuzyakov, 2013b), plants are able to release the mentioned enzymes as well (Spohn and Kuzyakov, 2013a), enhancing this process (Wasaki et al., 2003; Richardson et al., 2005). Uptake of this mineralized, inorganic phosphate by organisms leads to an immobilization of $P$ in the living biomass. The higher the turnover of the microbial biomass, the more frequently this temporarily immobilized $P$ source may become available to the plant. This may be particularly important for plants that form associations with saprophytes (such as OM) as most OM occur in the upper soil profiles which are highly enriched with organic matter 


\subsubsection{Phosphorus uptake by fungus}

Nutrients can reach plants by three mechanisms: i) root interception; ii) mass flow and iii) diffusion (Barber, 1984). Diffusion is considered to supply most of the $P$ absorbed by plants in the majority of soils (Barber, 1984). $\mathrm{P}$ is readily adsorbed by soils and so movement of $P$ through soils is typically very slow in comparison to other nutrients such as $\mathrm{N}$. As a result only the soluble inorganic phosphate in soil surrounding the roots reaches the plant (Bolan, 1991). The low mobility of phosphate in soils means that plant uptake rapidly leads to a zone of depletion surrounding the plant root system (Schachtman et al., 1998). In old, oligotrophic soil systems, the pool of available inorganic $\mathrm{P}$ can become increasingly impoverished through prolonged leaching and erosion (Lambers et al., 2008). The formation of mycorrhizal symbiosis allows plants to enhance the uptake of limiting nutrients such as P (Bolan, 1991; Marschner and Dell, 1994) (Table 2.3-2). Mycorrhizal associations have been shown to increase plant growth and this is believed to occur primarily through an increased physical exploration of the soil and an increased surface area for absorption to take place (Bolan, 1991; Cairney, 2011). Orchid mycorrhizal systems are one of several important mycorrhyzal symbioses, and may even engage with other mycorrhizal systems.

\subsubsection{Phosphorus uptake in Ectomycorrhizal Fungi}

ECM fungi form a mantle of fungal material that ensheaths the root tip: 1) an inwardly growing network of mycelium (Hartig Net) that grows between the epidermal and cortical cells, and 2) an outwardly growing network of mycelium that forages in the soil (Smith and Read, 2008) (Table 2.3-1). In contrast to the structure of AM-plant symbiosis, the ECM mantle provides a significant physical barrier that is likely to outcompete any passive root uptake of $P$ (Bücking et al., 2002; Taylor and Peterson, 2005). The mycelium growing out from the mantle into the surrounding soil is functionally crucial in acquiring nutrients and foraging well beyond the depletion zone (Bolan, 1991; Agerer, 2006). Comparative studies of non-mycorrhizal and ectomycorrhizal colonized plants have shown significant, up to four-fold increases in the uptake of $P$ (Heinrich and Patrick, 1986; Jones et al., 1998). For the ECM fungus Hebeloma cylindrosporum Romagn., the phosphate transporters HcPT1 and HcPT2, which are expressed in the Hartig net and the extramatrical mycelium and regulated by external $\mathrm{Pi}$ levels, were shown to be involved in mycorrhizal $\mathrm{P}$ uptake (Tatry et al., 2009; Garcia et al., 2013). 
Along with a greatly increased surface area, ectomycorrhizal fungi are able to exploit soil microsites that are otherwise inaccessible to roots. While this is not unique to ectomycorrhizal fungi, ECM do have the ability to access otherwise unavailable sources of $P$ (Landeweert et al., 2001). Ectomycorrhizal fungi actively mobilize, or 'mine', $P$ from solid mineral substrates through the excretion of organic acids and chelators (Table 2.3-2). Small pores and spaces in weatherable materials allow fungal hyphae to reach the interior of minerals and access $P$ from apatite (Wallander, 2000; Landeweert et al., 2001). Both the plant roots and the fungi can produce these P-mobilizing exudates and exudation by the roots is modified by the presence of ectomycorrhizal fungi and the type of mineral available (Bolan, 1991; Olsson and Wallander, 1998). There is also some evidence to suggest that ECM may be able to access pools of stored $P$ in saprotrophic fungi, thus bypassing uptake pathways of decomposition and mineralization (Lindahl et al., 1999).

\subsubsection{Phosphorus uptake in Arbuscular Mycorrhizal Fungi}

Arbuscular mycorrhiza are the most common mycorrhizal infection type, forming a symbiosis between a large number of host plants and fungi from the Glomeromycota (Schüßler et al., 2001; Smith and Read, 2008). There are important differences in the structure of roots infected by AM fungi as compared to other infection types, which have profound implications for nutrient uptake. Arbuscular mycorrhizal fungi form a hyphopodium on the host root surface from which fungal hyphae can penetrate the root, growing between root cells until reaching the cortex, proliferating along the root axis and penetrating the inner root cortical cells to form arbuscules (Arum-type infection) or hyphal coils that continue to spread from cell to cell (Paris-type infection) (Dickson, 2004; Smith and Read, 2008). This infection type leaves areas of the root surface free of hyphae and it was believed that the plant could use both the plant and fungal pathway for nutrient uptake. This had long been suggested to occur additively through direct uptake from the root and the AM fungi (Moyersoen et al., 1998). While this may occur in some cases, more recent studies using ${ }^{32} \mathrm{P}$ or ${ }^{33} \mathrm{P}$ show that the AM uptake pathway is likely to be the major route of $\mathrm{P}$ uptake (Smith et al., 2003; Smith and Smith, 2011). Arbuscular mycorrhizal plants have been shown to cause downregulation of $P$ transporters (Chiou et al., 2001) and induce their mycorrhiza-specific transporters (Xu et al., 2007) to shift the derivation of $P$ through the fungal pathway.

The plant-fungus combination can also greatly contribute to the functionality of the mycorrhizal pathway in P uptake. Smith et al. (2003) found that plants colonized by Glomus intraradices N.C. Schenck \& G.S. SM. (Glomeraceae) had all of their P supplied via the mycorrhizal pathway, whereas when plants were colonized by G. caledonium T.H. 
Nicolson \& Gerd, this was not true for Lycopersicon esculentum L. (tomato), which had only $70 \%$ of $\mathrm{P}$ supplied in this manner. Some fungal species have also been shown to suppress the expression of plant $P$ transporters for the plant uptake pathway (Grunwald et al., 2009). This suggests that the contribution of the mycorrhizal pathway to $P$ uptake is dependent on the compatibility of the symbiotic partners involved and the efficiency with which they can interact and exchange nutrients. It can be concluded that the main differences between ECM and $A M$ in $P$ uptake is that $A M$ can only access inorganic $P$ from the soil, whereas ECM are able to access both organic and inorganic P (Read, 1996; Smith and Read, 2008).

\subsubsection{Phosphorus uptake in orchid mycorrhiza}

Whereas orchids are one of the most diverse families in the plant kingdom, relatively little is known of their mineral nutrition in situ. Many orchids have a particularly poorly developed 'coarse' rather than fine root system, which has led to the long held, but rarely tested, assumption that orchids are highly dependent on their mycorrhiza for mineral nutrition, including P (e.g. Hadley and Williamson, 1972; Brundrett, 2007).

As found in AM, ECM and ERM systems (e.g. Hammer et al., 2011), C is allocated to the external mycelium to support $\mathrm{P}$ scavenging. Thus where orchids grow in $\mathrm{P}$ deficient or $\mathrm{P}$ inaccessible soils it may be that $\mathrm{C}$ trading between the orchid and mycorrhiza will facilitate $P$ uptake into the plant (Figure 2.3-1). It had been demonstrated that symbiotically grown seedlings of the orchid Goodyera repens (L.) R.Br. (Orchidaceae), absorbed significantly less $\mathrm{P}$ following treatment of the plantlets with fungicide in comparison to mycorrhizal plants (Alexander et al., 1984). However this remains one of the few studies of orchid $P$ nutrition.

Table 2.3-2: Phosphorus uptake in AM, ECM and OM

\begin{tabular}{|c|c|c|c|}
\hline & Sources & Pathway & $\begin{array}{l}\text { Cost/benefit } \\
\text { plant/fungus }\end{array}$ \\
\hline AM & Soluble inorganic $P$ & $\begin{array}{l}\text { Hyphae absorb P } \\
\text { transport to AM structures } \\
\text { (intercellular hyphae, } \\
\text { intracellular coils, intracellular } \\
\text { arbuscules), released to } \\
\text { interfacial apoplast adjacent to }\end{array}$ & $\begin{array}{l}\text { Plants provide the } \\
\text { fungus with } C \text { in } \\
\text { return assist in } \\
\text { scavenging } P \text { for the } \\
\text { plant. }\end{array}$ \\
\hline
\end{tabular}


root cortical cells (Smith et al

2003)

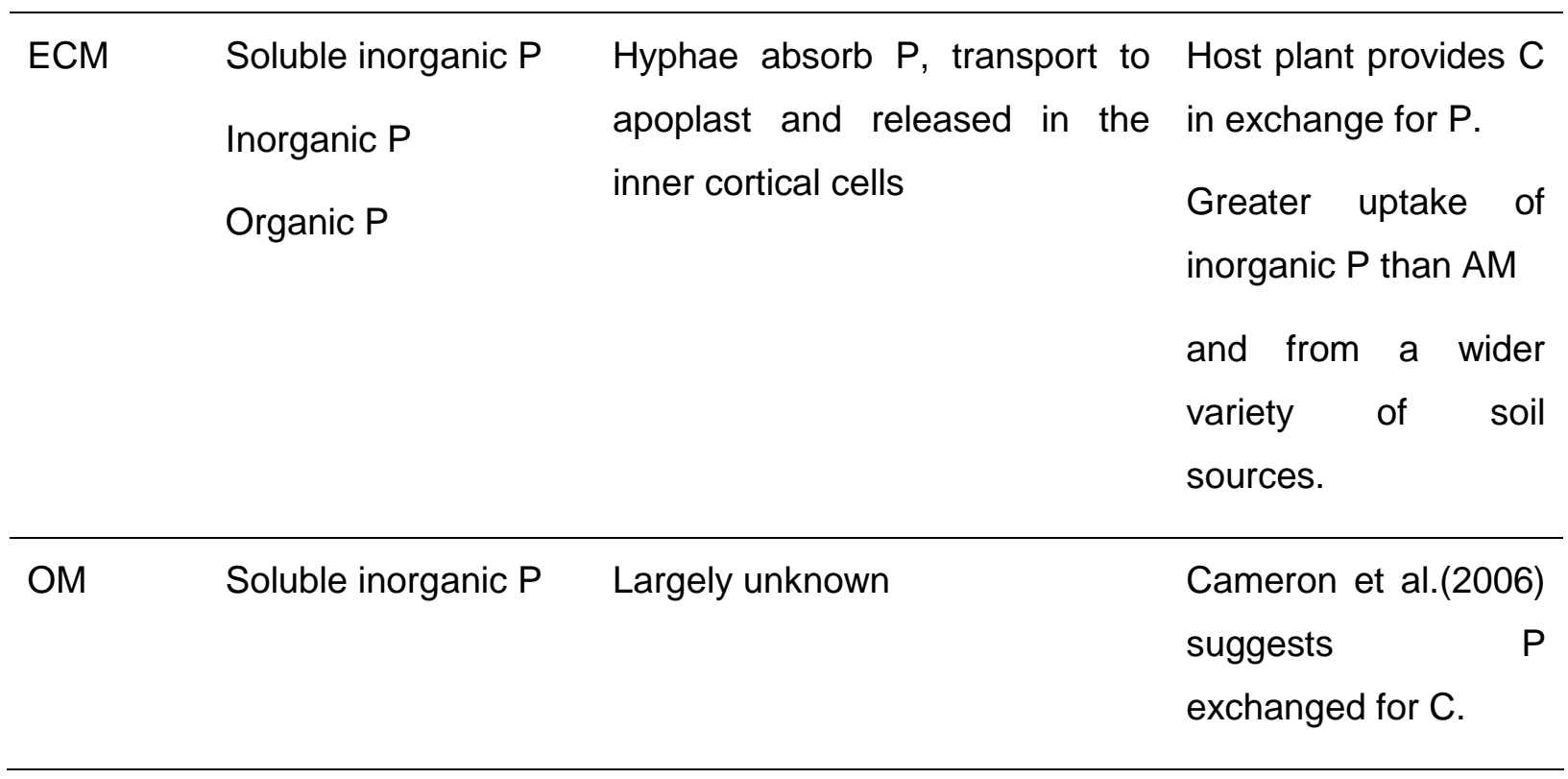




\subsubsection{Storage of $P$ in the fungus}

After $\mathrm{P}$ uptake from soil solution, fungi incorporate $\mathrm{P}$ into the cytosolic pool. The concentration is kept constant to maintain various cell functions, such as energy transfer and biosynthesis of phospholipids, nucleic acids and precursors of carbohydrate polymers such as UDP-glucose (Ezawa et al., 2002). Excess $P$ is transported into the vacuoles, effectively buffering the cytosolic P concentration (Klionsky et al., 1990; Shirahama et al., 1996). Up to $40 \%$ of total $P$ is transferred into the vacuoles (Bolan, 1991) and stored there as osmotically inactive polyphosphate granules. Polyphosphates exist as mobile (n_< 100 ) or immobile, long chained molecules ( $n>100$ ) (Gerlitz and Werk, 1994). Due to their rapid depletion under $\mathrm{P}$ limiting conditions, polyphosphates have been suggested to be the main source of fungal derived phosphate for host plants (Rasmussen et al., 2000; Pfeffer et al., 2001; Viereck et al., 2004). ${ }^{31} \mathrm{P}$-nuclear magnetic resonance (NMR) studies have enabled the differentiation and quantification of polyphosphates and various organic P forms (Martin et al., 1983; Martin et al., 1985; Grellier et al., 1989; Rasmussen et al., 2000; Pfeffer et al., 2001; Viereck et al., 2004). Besides vacuoles, long chained, precepitated orthophosphate residues are also stored in fungal tubular cisterns (Bücking and Heyser, 1999) with vacuolar granules containing phosphate and $\mathrm{Ca}$ found in both ecto- and endomycorrhizas (White and Brown, 1974; Chilvers and Harley, 1980; Strullu et al., 1981; Strullu et al., 1982).

Knowledge of $\mathrm{P}$ storage in $\mathrm{OM}$ is limited: there are few studies about the cellular location of stored $\mathrm{P}$ or the forms of $\mathrm{P}$ which are stored (Richardson et al., 1992), which suggest the presence of polyphosphate bodies. As $\mathrm{P}$ storage systems are evolutionarily well conserved within fungi (Beever and Burns, 1981; Terpitz and Kothe, 2012), OM are likely to parallel the syndromes found in ECM and AM .

\subsubsection{Phosphorus storage in ECM}

The transformation of accumulated inorganic phosphate into mobile polyphosphate with a medium chain length and the transformation of mobile into immobile polyphosphate either with long chain lengths or in granules occurs in ECM (Gerlitz and Werk, 1994). However, polyphosphates in ECM occur mainly in a dispersed soluble form in vacuoles of living, biochemically active hyphae (Cole et al., 1998). A high $P$ concentration in the fungus is maintained by the hydrolysis of polyphosphate, which is then catabolised by polyphosphatases or by reversal of polyphosphatekinase (Cox et al., 1980; Capaccio and Callow, 1982). Large granules are infrequent or even absent in the vacuole of living 
hyphae (Cole et al., 1998; Ashford et al., 1999) and Orlovich and Ashford (1993) showed these are mainly an artefact of specimen preparation. Very high cellular P contents, mostly balanced by potassium ions, occur in larger, spherical vacuoles, which can contain polyphosphate granules. Cole (1998) stated that those large vacuoles, are in a fixed position located in close association with the plasma membrane. If they move, they move along the membrane and can also function as a place of storage throughout the hyphae. Most of the vacuole system are tubular (Ashford, 1998; Cole et al., 1998), and have less contact with the plasma membrane and Allaway and Ashford (2001) proposed that the fixed storage vacuoles associated with the plasmalemma, are interconnected by tubules. The vacuole system in Pisolithus tinctorius (Pers) Coker \& Couch (Sclerodermataceae) hyphae has been shown to be both motile and interconnected. The apical cells of its fungal tips and to a lesser extent the basal hyphal cells in more mature regions can increase their motile activity and interconnectedness in response to changing environmental conditons (Hyde and Ashford, 1997). Both tubules and fixed spherical vacuoles contain a number of elements including high levels of $P$ and potassium (Orlovich and Ashford, 1993; Hyde and Ashford, 1997; Ashford, 1998; Cole et al., 1998). The distribution of $P$ is similar in both spherical vacuoles and tubules, suggesting that both might play a role in the longitudinal long distance hyphal movement of $P$ (Hyde and Ashford, 1997). Inorganic phosphate absorbed by hyphae can also be stored as soluble orthophosphate (Harley and Loughman, 1963) or soluble polyphosphate (Martin et al., 1983; Loughman and Ratcliffe, 1984). In vivo transport of $\mathrm{P}$ can be observed in intact systems using radioactive tracers $\left({ }^{32} \mathrm{P}\right.$ and $\left.{ }^{33} \mathrm{P}\right)$ showing translocation throughout the fungal network and towards the roots of the host plants (Lindahl et al., 2001; Lindahl and Olsson, 2004; Cameron et al., 2007; Wu et al., 2012). In addition, it is also possible to generate elemental maps of mycorrhizal roots showing the distribution of $P$ through the use of micro-particle-induced-X-ray emission (Bücking and Heyser, 1999; Bücking and Shachar-Hill, 2005; Orłowska et al., 2008). Ectomycorrhizal basidiomycetes growing in axenic culture can store $\mathrm{P}$ as orthophosphate or polyphosphate, depending on species or culture conditions (Martin et al., 1983; Martin et al., 1985; Mousain and Salsac, 1985; Cairney and Chambers, 1997; Gerlitz and Gerlitz, 1997). Those diverse storage forms the biochemical possibilities and the interconnected tubular vacuole system might be the reason for the high $\mathrm{P}$ concentration in the $\mathrm{ECM}$.

\subsubsection{Phosphorus storage in AM}

Of the various cellular functions where fungi supply the plant with $\mathrm{P}$ (Kornberg et al., 1999), the most important is the temporary storage of inorganic $P$ in the vacuolar $P$ pool of AM hyphae (Ezawa et al., 2002) (Table 2.3-3). Chain-length of polyphosphate in AM fungi 
is variable (Ezawa et al., 1999), longer in extraradical than in intraradical hyphae but both soluble and long-chain granular forms occur in the intra- and extraradical hyphae (Solaiman et al., 1999). Many factors may affect the solubility of polyphosphate in vivo, including $\mathrm{pH}$, chain-length, concentration of polyphosphate and counter ions such as metal cations and polyamines (Harold, 1966; Cramer and Davis, 1984). The efficiency of the AM mycorrhizal association in $\mathrm{P}$ nutrition of a host plant is highly geared to the ability of the AM to accumulate $P$ when external supply is high and remobilise this stored pool of $P$ under limiting conditions, thereby maintaining a continuous suppy of $P$ to the plant (Bücking and Heyser, 2000). 


\subsubsection{Transport of $P$ in the fungus-plant interface}

\subsubsection{Transport of $P$ in ECM}

The transfer of $\mathrm{P}$ in mycorrhiza occurs either as: 1) passive translocation in the hyphae; or 2) passive and active transport of inorganic $P$ into the root. Translocation of $P$ within the hyphae occurs passively along a concentration gradient between the $\mathrm{P}$ source in the external hyphae and a $\mathrm{P}$ sink in the root supported by cytoplasmic streaming (Bolan, 1991). Transport in the hyphae is influenced by the intracellular $P$ concentration of the hyphae because it regulates the $P$ absorption by the fungus (Thomson et al., 1990; Cairney and Smith, 1992). In addition, it has been proposed that motile tubular vacuoles may function in both intracellular and intercellular transport of mineral nutrients. Pleiomorphic vacuolar tubules found in extraradical hyphae and in the fungal sheath containing polyphosphate move rapidly, extend, retract, fuse, and even pass through dolipore septa and are present throughout the entire fungal system (Orlovich and Ashford, 1994; Ashford, 1998; Shoji et al., 2006). These motile tubular vacuoles might be responsible for the rapid short and long distance transfer in the extraradical mycelium of ECM (Hyde and Ashford, 1997; Allaway and Ashford, 2001; Smith and Read, 2008).

$A$ rapid bidirectional transfer of $P$ and carbohydrates occurs between the root and the hyphae at the fungus-root interface (Figure 2.3-1). This involves both the passive efflux of $\mathrm{P}$ and carbohydrates through the fungal and plant plasma membranes into the interfacial apoplast and active exchange of nutrients between both partners (Smith and GianinazziPearson, 1988; Smith and Smith, 1989; Smith and Smith, 1990; Bücking and Heyser, 2000). For passive uptake into the plant, it is known that the contrast between the high $P$ concentration in the hyphae of the Hartig net and the low $P$ concentrations in the interfacial apoplast and the cortical cells causes the passive efflux of $P$ from the hyphae into the interfacial apoplast and host plant (Smith et al., 1994). This occurs mainly by maintaining the $\mathrm{P}$ concentration gradient due to allocation of $\mathrm{P}$ either into $\mathrm{P}$ storage pools such as vacuoles in the cortical cells or to rapid transfer to $P$ sinks such as the meristematic tissue and the nuclei of root cells (Bücking and Heyser, 1997) or aboveground plant parts. A second mechanism may also exist: high -low affinity $P$ transporters have been identified which might be involved in the active transfer of $P$ at the symbiotic interface (Smith and Read, 2008). This supply of $P$ for plants might be quantitatively linked to loss of sugars to the interfacial apoplast. The relevance of both mechanisms and their dependence on ecological conditions is an area of further work particularly relevant to OM (see below). Also interesting would be stoichiometric approach 
for the exchange between $\mathrm{P}$ and sugars, e.g. the mole sugars that are necessary for plant to deliver and to obtain one mole of phosphate.

\subsubsection{Transport of $P$ in $A M$}

In arbuscular mycorrhizal associations $\mathrm{P}$ is transferred from the fungus to the plant and $\mathrm{C}$ from the plant to the fungus (Ezawa et al., 2002). The long distance transfer of $P$ from the external mycelium to the plant is probably achieved via transfer of vacuolar components into the fungal arbuscules and from there to the interfacial apoplast (Ezawa et al., 2002). The P-rich granules were shown to be the main form of $\mathrm{P}$ transport over long distances in AM fungi such as Glomus mosseae T.H. Nicolson \& Gerd. (Callow et al., 1978; Cox et al., 1980). Ezawa et al. (2002) suggests that the transport would take place either by protoplasmic streaming or the motile tubular vacuole-like system. It is likely also that organic $\mathrm{P}$ molecules are present and may be part of the $\mathrm{P}$ pool delivered to the plant. $\mathrm{A}$ constant, length-specific $P$ uptake by hyphae within $A M$ species and a consequent $P$ accumulation in AM hyphae were shown but exhibited a poor capacity for $\mathrm{P}$ delivery to the plant (Ezawa et al., 2002; Munkvold et al., 2004). Even if, as Harrison (1999) suggests, the presence of ATPases at the symbiotic interface indicates a possible active nutrient transfer, the biochemical and biophysical processes of this transfer across this interface is still unknown for AM.

\subsubsection{Transport of $P$ in $O M$}

Fungi provide $\mathrm{C}, \mathrm{N}$ and $\mathrm{P}$ to partially and fully mycoheterotrophic orchids (Figure 2.3-1). However, little is known about plant-to-fungus transfer and subsequent benefits to the fungus (Cameron et al., 2006; Cameron et al., 2008). Cameron et al. (Cameron et al., 2006; Cameron et al., 2008) demonstrated a mutualistic, bidirectional $C$ transfer between the green orchid Goodyera repens (L.) R. Br. and the fungus Ceratobasidium D.P. Rogers (Ceratobasidiaceae). After the initially mycoheterotrophic phase of development, the symbiosis in green-leaved adults follows the conventional pattern of mycorrhizal mutualisms: $C$ from the plant is exchanged for mineral nutrients accumulated by the fungus (Cameron et al., 2007) (Table 2.3-3). Smith (1967) showed the direct transfer of ${ }^{32} \mathrm{P}$ from fungus to protocorms and Alexander et al. (1984) the transfer of ${ }^{32} \mathrm{P}$ into Goodyera repens (L.) R. Br.. Cameron et al. (2007) showed for the first time that the intact external mycelium of Ceratobasidium cornigerum (Bourdot) D.P. Rogers (Ceratobasidiaceae) could assimilate $P$ (supplied as ${ }^{33} \mathrm{P}$ ) and facilitate its transfer to adult roots and shoots of $G$. repens (L.) (Table 2.3-3). This provides some evidence for reciprocal transfer of $\mathrm{C}$ and $\mathrm{P}$ in the Rhizoctonia-orchid symbiosis; the same has also 
been shown to occur in the case of $N$ (Cameron et al., 2006). Thus the mycorrhizas of Rhizoctonia-colonized orchids appear to function in the same way as those of AM and ECM systems. However, until now all knowledge is based upon the analysis of a single European orchid species. There is also circumstantial evidence that orchids may derive $P$ from both, intact pelotons as well as lysed pelotons (Rasmussen and Rasmussen, 2009). However, further work is required to delineate the exact means of $P$ transport in orchids. There is clearly a need to extend such analyses to regions with a far greater diversity of orchid species and with a wider range of nutritional and ecological gradients to deepen our understanding of the effect of environmental factors on physiological process like $P$ transport. 
Table 2.3-3: Phosphorus budget expressed as percentage of whole plant $P$ allocated to various organs of mycorrhizal plants. The molybdite blue (Murphy and Riley, 1962) or adapted methods were used to estimate the percentage of $P$ in the organs of mycorrhizal plants.

\begin{tabular}{|c|c|c|c|c|c|c|c|c|}
\hline \multirow{2}{*}{$\begin{array}{l}\text { Host } \\
\text { Species }\end{array}$} & \multirow[b]{2}{*}{$\begin{array}{l}\text { Mycorrhizal } \\
\text { species and } \\
\text { infection type }\end{array}$} & \multicolumn{7}{|c|}{ P percentage in various plant organs } \\
\hline & & $\begin{array}{l}\text { myc } \\
\text { orrhi } \\
\text { za }\end{array}$ & roots & stem & leaf & Flowers & $\begin{array}{l}\text { Study } \\
\text { system }\end{array}$ & Reference \\
\hline $\begin{array}{l}\text { Eucalyptus } \\
\text { pilularis }\end{array}$ & $\begin{array}{l}\text { Unknown } \\
\text { (ECM) }\end{array}$ & - & 38 & 16 & 44 & - & $\begin{array}{l}\text { Microco } \\
\text { sm }\end{array}$ & $\begin{array}{l}\text { Mulligan } \\
\text { and Patrick, } \\
1985\end{array}$ \\
\hline \multirow[t]{2}{*}{$\begin{array}{l}\text { Pinus } \\
\text { sylvestris }\end{array}$} & $\begin{array}{l}\text { Thelephora } \\
\text { terrestris (Tt- } \\
\text { 0994-Lommel) } \\
\text { (ECM) }\end{array}$ & 12 & 50 & - & 38 & - & $\begin{array}{l}\text { Hydropo } \\
\text { nic }\end{array}$ & $\begin{array}{l}\text { Colpaert } \\
\text { and } \\
\text { Verstuyft, } \\
1999\end{array}$ \\
\hline & $\begin{array}{l}\text { Suillus luteus } \\
\text { (SI-0994-Paal) } \\
\text { (ECM) }\end{array}$ & 16 & 48 & - & 36 & - & & \\
\hline $\begin{array}{l}\text { Fragraria } x \\
\text { ananassa }\end{array}$ & Unknown (AM) & - & 9.4 & 1.1 & $\begin{array}{c}37 . \\
9\end{array}$ & $51.3^{*}$ & Field & $\begin{array}{l}\text { Dunne and } \\
\text { Fitter, } 1989\end{array}$ \\
\hline $\begin{array}{l}\text { Hyacinthoi } \\
\text { des non- } \\
\text { scripta }\end{array}$ & $\begin{array}{l}\text { Unknown } \\
\text { Glomalean } \\
\text { (AM) }\end{array}$ & - & $\begin{array}{c}13 \\
(45 \\
\text { bulb) }\end{array}$ & - & 13 & $\begin{array}{l}9(20 \\
\text { seed })\end{array}$ & $\begin{array}{l}\text { Microco } \\
\text { sm and } \\
\text { field }\end{array}$ & $\begin{array}{l}\text { Merryweath } \\
\text { er and } \\
\text { Fitter, } 1995\end{array}$ \\
\hline \multirow[t]{3}{*}{$\begin{array}{l}\text { Cucumis } \\
\text { sativus }\end{array}$} & $\begin{array}{l}\text { Scutellospora } \\
\text { callospora } \\
((\mathrm{WUM12(2))} \\
(\mathrm{AM})\end{array}$ & - & 15.2 & - & $\begin{array}{c}84 . \\
8\end{array}$ & - & $\begin{array}{l}\text { Microco } \\
\text { sm }\end{array}$ & $\begin{array}{l}\text { Pearson } \\
\text { and } \\
\text { Jakobsen, } \\
1993 \\
\end{array}$ \\
\hline & $\begin{array}{l}\text { Glomus } \\
\text { caledonium } \\
\text { (RIS 42) }\end{array}$ & - & 14.5 & - & $\begin{array}{c}85 . \\
4\end{array}$ & - & & \\
\hline & $\begin{array}{l}\text { Glomus sp. } \\
\text { (WUM 10(1)) }\end{array}$ & - & 16.1 & - & $\begin{array}{c}83 . \\
8\end{array}$ & - & & \\
\hline \multirow[t]{3}{*}{$\begin{array}{l}\text { Medicago } \\
\text { trunculata }\end{array}$} & $\begin{array}{l}\text { Glomus } \\
\text { intraradices } \\
\text { (AM) }\end{array}$ & - & 30 & - & 70 & - & & $\begin{array}{l}\text { Lendenman } \\
\mathrm{n} \text { et al., } \\
2011\end{array}$ \\
\hline & $\begin{array}{l}\text { Glomus } \\
\text { claroideum } \\
\text { (AM) }\end{array}$ & - & 28.6 & - & $\begin{array}{c}71 . \\
4\end{array}$ & - & & \\
\hline & $\begin{array}{l}\text { Gigaspora } \\
\text { margerita (AM) }\end{array}$ & - & 33.3 & - & $\begin{array}{c}66 . \\
7\end{array}$ & - & & \\
\hline $\begin{array}{l}\text { Goodyera } \\
\text { repens }\end{array}$ & $\begin{array}{l}\text { Ceratobasidiu } \\
m \text { cornigerum } \\
\text { (OM) }\end{array}$ & 83.5 & 5.4 & - & 6.3 & - & $\begin{array}{l}\text { Microco } \\
\text { sm }\end{array}$ & $\begin{array}{l}\text { Cameron et } \\
\text { al., } 2007\end{array}$ \\
\hline
\end{tabular}

*includes allocation to fruit also 


\subsubsection{Phosphorus deficient ecosystems}

$\mathrm{P}$ in soil, unlike $\mathrm{N}$ and $\mathrm{C}$, is not replenishable from the atmosphere and as such is a finite resource mainly derived from weathering of parent material (Smeck, 1985; Lambers et al., 2008; Selmants and Hart, 2010). In regions of geological stability and old age, there is a proliferation of soils that are highly deficient in nutrients (Lindsay, 1985; Orians and Milewski, 2007; Hopper, 2009b), especially in P (Figure 2.3-3). California Floristic Province, West Ecuador/ Tropical Andes, Mesoamerica, Mediterranean Basin, the southwest of Australia and the greater Cape region of Africa are regions of extreme nutrient deficiency and biodiversity hotspots for conservation priorities (Myers et al., 2000), and have been classified as being very old, stable and climatically buffered landscapes which are P limited (Turkington et al., 2005; Lambers et al., 2008; Hopper, 2009a; Reich, 2015) (Figure 2.3-3). The paucity of available nutrients in soils has pushed these regions to become biodiversity hotspots, with exceptionally high levels of plant endemism (Cowling et al., 1996; Lambers et al., 2008; Hopper, 2009b)

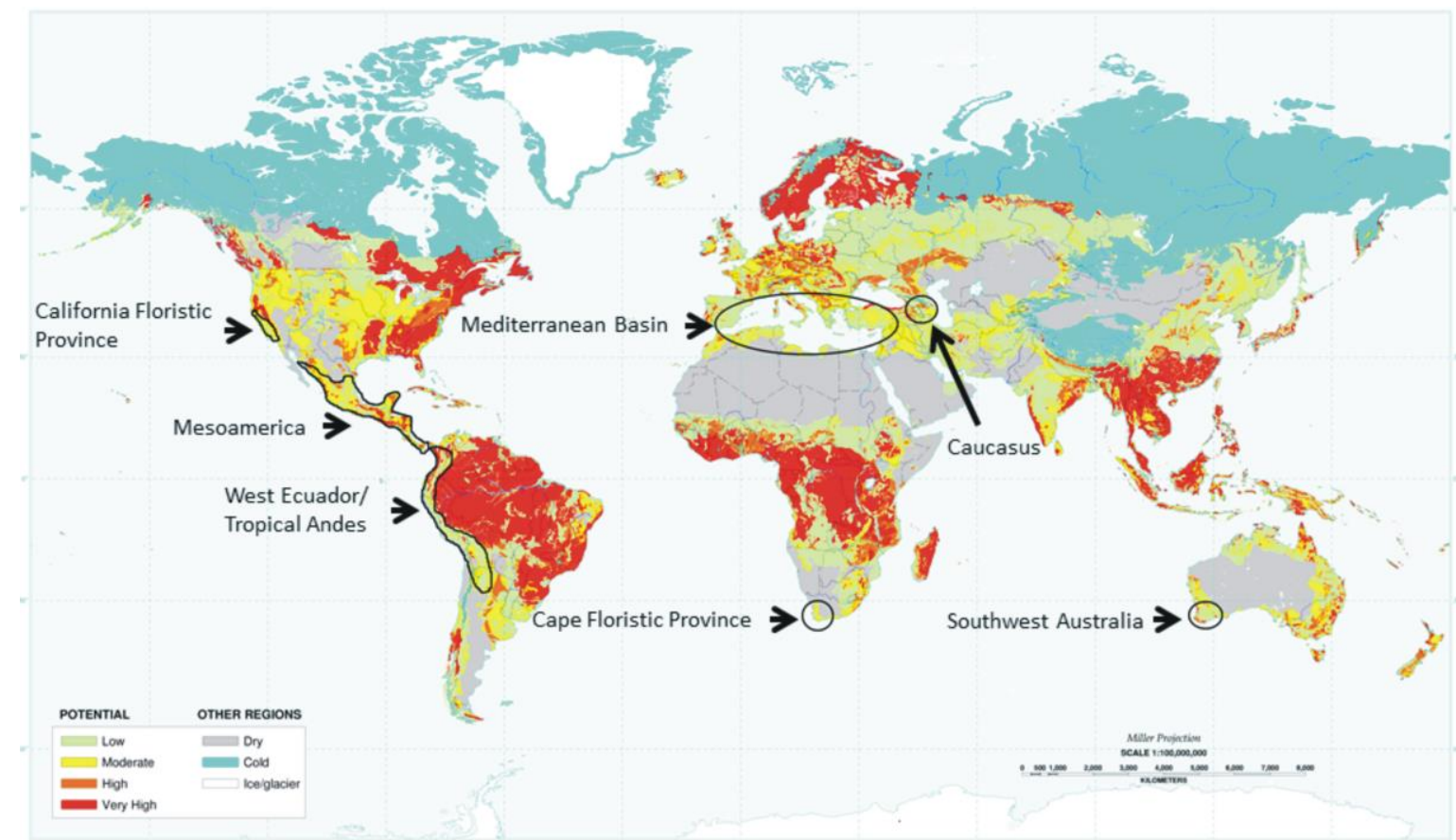

Figure 2.3-3: Phosphorus retention map with selected biodiversity hotspots in $P$ deficient regions (Myers et al., 2000; Reich, 2015)

The flora of these regions has evolved a multitude of strategies to overcome the low nutrient levels, ranging from preventing nutrient loss from herbivory through intense sclerophylly, to being extremely efficient at remobilizing essential nutrients (Handreck, 
1997; Lambers et al., 2008; Selmants and Hart, 2010). To overcome P deficiency in these soils, plants have developed not only physiological mechanisms, where they either modify root morphologies (cluster roots) or engage in mycorrhizal relationships to maximize $\mathrm{P}$ uptake (Pate, 1994; Lambers et al., 2002; Orians and Milewski, 2007; Lambers et al., 2008; Selmants and Hart, 2010).

Cluster roots are formed by both monocots and dicots, and are characterized by the formation of clusters of densely packed lateral rootlets (Lambers et al., 2008; Lambers et al., 2013). Due to the production and secretion of phosphatases and carboxylates into the surrounding soil, cluster roots are able to access both organic and inorganic forms of $P$ (Alexander et al., 1984; Lambers et al., 2002; Shane et al., 2004; Lambers et al., 2008; Lambers et al., 2013). Cluster roots are a specialized adaptation evolved on extremely nutrient poor soils, with long periods of weathering. This extreme adaptation to nutrient poor soils observed in cluster root forming plants has resulted in an inability to downregulate their $\mathrm{P}$ uptake capacities, and they can display $\mathrm{P}$ toxicity even when exposed to slightly elevated P levels (Lambers et al., 2002; Shane et al., 2004; Lambers et al., 2008; Lambers et al., 2013). Arbuscular mycorrhizas can only access inorganic P from the soil, whereas ECM and ericoid mycorrhizas are able to access both organic and inorganic $P$ (Read, 1996; Smith and Read, 2008) (Figure 2.3-2). However, in soils with high P levels, only ECM are able to uptake and store excess $P$ in their hyphae, presumably as polyphosphates, releasing the stored $\mathrm{P}$ to the host if deficiency occurs (Smith and Read, 2008). The formation of $A M$ on the other hand is inhibited at elevated $P$ concentrations (Handreck, 1997; Smith and Read, 2008). Nothing is known about the influence of available $\mathrm{P}$ on the formation or behavior of orchid mycorrhiza in these environments. However the hypothesis that low levels of $P$ have encouraged diversification of terrestrial orchids (Brown et al., 2008) is confirmed by the fact that the Cape and southwestern Australia are particularly rich in orchid species and diversity (Liltved and Johnson, 2012). 


\subsubsection{Epiphytic orchids-a special case in $\mathrm{P}$ deficient survival}

Considerable research is now focused on ascribing the identities of mycorrhizal fungi to epiphytic orchids whereas a larger literature exists on describing the diversity of terrestrial taxa - most likely reflecting the temperate regions where most orchid scientists reside. It has been long assumed that orchids have a heavy reliance on a mycorrhizal partner for their mineral nutrition, due to their highly reduced and coarse root system (Brundrett, 2007). However, there has been very little experimental evidence showing the degree to which orchids rely on their mycorrhizas outside of the dependency upon fungal infection to commence germination under field conditions. In terms of obtaining mineral nutrients, particularly $\mathrm{P}$, terrestrial orchids have a distinct advantage over epiphytic species in being able to undertake direct ion exchange as they are in contact with the soil matrix. However, epiphytic orchids exist in perhaps one of the most $P$ impoverished environments, where the window for nutrient acquisition may only be open for brief intervals when the plant is in contact with rainfall and leachates from the canopy or, in the case of lithophytic orchids, from the surrounding rock face (Benzing, 1973; Zotz and Richter, 2006; Cardelús and Mack, 2010). Typically, precipitation that is intercepted by the forest canopy and flows down trunks or passes through foliage will usually contain the highest quantities of nutrients. However nutrient levels in water percolating across bark or rock is extraordinarily low (McColl, 1970; Benzing, 1973). Nutrient composition of through fall relies on the composition of the rainfall and also the leachability of ions from bark or foliage (Benzing, 1973; Jordan et al., 1980). Consequently, trees with P-rich bark and foliage are often preferentially colonized by epiphytes (Benner, 2011; Wanek and Zotz, 2011), though this issue has not been studied with orchids. $P$ is the element with lowest concentration of all nutrients $(<0.1 \mathrm{ppm})$ as it is not readily leached from the canopy or from bark/rock inhabiting lichens and algae (Stenlid, 1958; Jordan et al., 1980; Li, 1998). Nutrient composition, through fall and stem flow studies have revealed a disconnection between canopy and ground nutrient pools and very tight cycling of $P$ in the canopy of rainforest systems. This had led to the current notion that these systems are extraordinarily P-limited environments (Zotz and Hietz, 2001; Zotz and Richter, 2006; Cardelús and Mack, 2010).

To overcome living in such a nutrient-poor environment, epiphytic orchids have developed a number of remarkable adaptations. They often have slow rates of growth as a counter to the longer accumulation times required for nutrient acquisition (Benzing, 1973), are commonly smaller in size with a larger investment in root structures (Schmidt et al., 2001; 
Zotz and Hietz, 2001) and, exhibit the ability to recycle nutrients by retaining leaf, root and storage organs (leaf-based or specialized hypertrophic tissues known as pseudobulbs) for use in vegetative reproduction and as a pool of nutrients and water storage (Zotz, 1999). The velamen radicum, a spongy multiple-layered epidermis that covers the aerial roots provides a rapid adsorption and retention tissue for the first flush of nutrient rich water flowing down the bark or rock face and is thought to be a key adaptation to epiphytic life (Zotz and Winkler, 2013). Clearly these adaptations to life in the 'air' are highly advantageous as $60 \%$ of orchids are epiphytic with some genera having many hundreds to thousands of species (Pridgeon et al., 1999 ). Therefore there is a need to understand both the fungal diversity associated with epiphytic species and also the functional significance throughout the life cycle of the orchid. 


\subsubsection{Conclusions}

Mobility and availability of $P$ in soils is typically low because of rapid absorption and or precipitation. The beneficial role of mycorrhiza to uptake dissolved, and mobilize sorbed, organic and mineral $\mathrm{P}$ forms from soil behind the $\mathrm{P}$ depletion zone of the root is clearly highly advantageous to the plant (Bolan, 1991). Mycorrhiza use i) biochemical, e.g. chelation and acidification, ii) biophysical strategies, e.g. protoplasmic streaming to increase the effectiveness and absorption surface for the $P$ from the soil (Bolan, 1991; Cairney, 2011), as well as iii) by occupation much larger space compared to the roots.

The mycorrhizal associations are efficient for the $\mathrm{P}$ nutrition not only by increased $\mathrm{P}$ absorption, but by the capability to accumulate $P$, when the external supply is high and to remobilize this stored pool in periods of $P$ deficiency (Bücking and Heyser, 2000). There is an ongoing discussion about existence and dispersal of polyphosphate granules and the motile vacuole system and how it is interconnected with tubules in both AM and ECM (Orlovich and Ashford, 1993; Gerlitz and Werk, 1994; Cole et al., 1998; Ashford et al., 1999). Further research is required to understand $P$ storage pools, mobilization processes and responses to changing environmental conditons and the cellular location and type(s) of stored $\mathrm{P}$, particularly in $\mathrm{OM}$.

In $\mathrm{OM}$, the mutualistic, bidirectional $\mathrm{C}$ and $\mathrm{N}$ transfer and $\mathrm{P}$ uptake and transfer to roots have been shown only recently, and very little is known about the mechanisms of plant-tofungus transfer and benefits to the fungus (Cameron et al., 2006; Cameron et al., 2007; Cameron et al., 2008). It also unclear if orchids may derive their $P$ from both, intact pelotons as well as lysed pelotons (Serrigny and Dexheimer, 1985)(cited in Smith and Read, 2008).

Partially mycoheterotrophic orchids depend on ectomycorrhizal fungi for seedling and adult development and may specialize on more narrow groups of fungi during germination than in adulthood (Bidartondo and Read, 2008). Since ECM are more efficient in the uptake and transport of $\mathrm{P}$, and are able to access a broader spectrum of $\mathrm{P}$ sources compared to AM there are clear advantages for orchids to link via ECM particularly in nutrient and even light-limiting environments. Gebauer and Meyer postulated (cited in Bidartondo et al. 2008) that photosynthetic forest orchids are connected both to typical $\mathrm{OM}$ and to ECM. So maybe there is not even a change but rather a regulation to obtain $\mathrm{P}$ from the soil in exchange for $C$ from the plant depending on the photosynthetic activity or stage in the orchid's lifecycle. However it remains to be known for the majority of orchids 
exactly what is the role and function of mycorrhiza in $\mathrm{P}$ nutrition and this remains an exciting area for future research. 


\subsubsection{Acknowledgments}

Janine Sommer would like to acknowledge the generous funding of the Deutsche Forschungsgemeinschaft, Belinda Newman was supported by the Australian Research Funding and both Wei-Han Lim and B. Davis were supported by the School of Plant Biology, University of Western Australia. We thank also M. Dippold, V. Temperton and M. Spohn for their helpful and constructive comments on the manuscript. 


\subsubsection{References}

Agerer, R. (2006): Fungal relationships and structural identity of their ectomycorrhizae. Mycological Progress 5, 67.

Alexander, C., Alexander, I. J., Hadley G. (1984): Phosphate-uptake by Goodyera repens in relation to mycorrhizal infection. New Phytologist 97, 401.

Allaway, W. G., Ashford, A. E. (2001): Motile tubular vacuoles in extramatrical mycelium and sheath hyphae of ectomycorrhizal systems. Protoplasma 215, 218.

Arditti, J., Ghani, A. K. A. (2000): Numerical and physical properties of orchid seeds and their biological implications. New Phytologist 146, 569.

Ashford, A. E. (1998): Dynamic pleiomorphic vacuole systems: Are they endosomes and transport compartments in fungal hyphae? Advances in Botanical Research 28, 119.

Ashford, A. E., Vesk, P. A., Orlovich, D. A., Markovina, A., Allaway, W. G. (1999): Dispersed polyphosphate in fungal vacuoles in Eucalyptus pilularis/Pisolithus tinctorius ectomycorrhizas. Fungal Genetics and Biology 28, 21.

Atwood, J. T. (1986): The size of the Orchidaceae and the systematic distribution of epiphytic orchids. Selbyana, 171.

Barber, S. A. (1984): Soil nutrient bioavailability a mechanistic approach. John Wiley and Sons Inc.: New York, USA.

Baylis, G. T. S. (1975): The magnolioid mycorrhiza and mycotrophy in root systems derived from it Academic Press, London, UK. p. 373

Beever, R. E., Burns D. J. W. (1981): Phosphorus uptake, storage and utilization by fungi. Advances in Botanical Research 8, 127.

Benner, J. W. (2011): Epiphytes preferentially colonize high-phosphorus host trees in unfertilized Hawaiian montane forests. The Bryologist 114, 335.

Benzing, D. H. (1973): Monocotyledons - their evolution and comparative biology .1. Mineral nutrition and relatd phenomena in Bomeliaceae and Orchidaceae. Quarterly Review of Biology 48, 277.

Benzing, D. H. (1996): Aerial roots and their environnment. In Y. Waise, A. Eshel and U. Kafkafi: Plant Roots, The Hidden Half. Marcel Dekker, inc: New York, 875-894.

Benzing, D. H., Friedman, W. E., Peterson, G., Renfrow, A. (1983): Shootless, velamentous roots, and the pre-eminence of Orchidaceae in the epiphytic biotope. American Journal of Botany 70, 121.

Benzing, D. H., Friedman, W. E. (1981): Mycotrophy: It's occurrence and possible significance among epiphytic Orchidaceae. Selbyana 5, 243

Bidartondo, M. I., Burghardt, B., Gebauer, G., Bruns, T. D., Read, D. J. (2004): Changing partners in the dark: isotopic and molecular evidence of ectomycorrhizal liaisons between forest orchids and trees. Proceedings of the Royal Society of London Series B-Biological Sciences 271, 1799.

Bidartondo, M. I., Read, D. J. (2008): Fungal specificity bottlenecks during orchid germination and development. Molecular Ecology 17, 3707.

Blume, H. P., Brümmer, G. W., Horn, H., Kandeler, E., Kögel-Knabner, I., Stahr, K., Wilke, B.M. (2010): Lehrbuch der Bodenkunde. Spektrum Akademischer Verlag, Heidelberg. p. 412-418. 
Bolan, N. S. (1991): A Critical-Review on the Role of Mycorrhizal Fungi in the Uptake of Phosphorus by Plants. Plant and Soil 134, 189.

Brundrett, M. (2004): Diversity and classification of mycorrhizal associations. Biological Reviews 79, 473.

Brundrett, M. (2007): Scientific approaches to Australian temperate terrestrial orchid conservation. Australian Journal of Botany 55, 293.

Brundrett, M., Abbott, L. K. (2002): Arbuscular mycorrhizas in plant communities. In K. Sivasithamparam, K. W. Dixon and R. L. Barrett: Microorganisms in Plant Conservation and Biodiversity. Springer: Dorgrecht, Netherlands, 151-193.

Bücking, H., Heyser, W. (1997): Intracellular compartmentation of phosphorus in roots of Pinus sylvestris $\mathrm{L}$. and the implications for transfer processes in ectomycorrhizae. p. 377-391.

Bücking, H., Heyser, W. (1999): Elemental composition and function of polyphosphates in ectomycorrhizal fungi - an X-ray microanalytical study. Mycological Research 103, 31.

Bücking, H., Heyser, W. (2000): Subcellular compartmentation of elements in nonmycorrhizal and mycorrhizal roots of Pinus sylvestris : an X-ray microanalytical study. I. The distribution of phosphate. New Phytologist 145, 311.

Bücking, H., Kuhn, A. J. , Schroder, W. H., Heyser, W. (2002): The fungal sheath of ectomycorrhizal pine roots: an apoplastic barrier for the entry of calcium, magnesium, and potassium into the root cortex? Journal of Experimental Botany 53, 1659.

Bücking, H., Shachar-Hill, Y. (2005): Phosphate uptake, transport and transfer by the arbuscular mycorrhizal fungus Glomus intraradices is stimulated by increased carbohydrate availability. New Phytologist 165, 899.

Burgeff, H. (1959): Mycorrhiza of orchids. In C. Withner: The orchids a scientific survey. Ronald Press: New York, 361-395.

Cairney, J. W. G., Chambers, S. M. (1997): Interactions between Pisolithus tinctorius and its hosts: A review of current knowledge. Mycorrhiza 7, 117.

Cairney, J. W. G., Smith, S. E. (1992): Influence of intracellular phosphorus concentration on phosphate absorbtion by the ectomycorrhizal Basidiomycete Pisolithotustinctorius Mycological Research 96, 673.

Cairney, J. W. G. (2011): Ectomycorrhizal fungi: the symbiotic route to the root for phosphorus in forest soils. Plant and Soil 344, 51.

Callow, J. A., Capaccio, L. C. M., Parish, G., Tinker, P. B. (1978): Detection and estimation of polyphosphate in vesicular-arbuscular mycorrhizas. New Phytologist 80, 125.

Cameron, D. D., Johnson, I., Leake, J. R., Read, D. J. (2007): Mycorrhizal acquisition of inorganic phosphorus by the green-leaved terrestrial orchid Goodyera repens. Annals of Botany 99, 831.

Cameron, D. D., Johnson, I., Read, D. J., Leake, J. R. (2008): Giving and receiving: measuring the carbon cost of mycorrhizas in the green orchid, Goodyera repens. New Phytologist 180, 176.

Cameron, D. D., Leake, J. R., Read, D. J. (2006): Mutualistic mycorrhiza in orchids: evidence from plant-fungus carbon and nitrogen transfers in the green-leaved terrestrial orchid Goodyera repens. New Phytologist 171, 405.

Capaccio, L. C. M., Callow, J. A. (1982): The enzymes of polyphosphate metabolism in Vesicular-Arbuscular Mycorrhizas. New Phytologist 91, 81. 
Cardelús, C.L., Mack, M. C. (2010): The nutrient status of epiphytic ferns, orchids and bromeliads and their host tree along an elevation gradient, Costa Rica. Plant Ecology 207, 25.

Chase, M. W., Cameron, K. M., Barrett, R. L., Freudenstein, J. V. (2003): DNA data and Orchidaceae systematics: a new phylogenetic classification. In K. W. Dixon, S. P. Kell, R. L. Barrett and P. J. Cribb: Orchid conservation. Natural History Publications: Kota Kinabalu, Sabah, Malaysia, 69-89.

Chilvers, G. A., Harley, J. L. (1980): Visualization of phosphate accumulation in beech mycorrhizas. New Phytologist 84, 319.

Chiou, T. J., Liu, H., Harrison, M. J. (2001): The spatial expression patterns of a phosphate transporter (MtPT1) from Medicago truncatula indicate a role in phosphate transport at the root/soil interface. Plant Journal 25, 281.

Cole, L., Orlovich, D. A., Ashford, A. E. (1998): Stucture, Function, and Motility of Vacuoles in Filamentous Fungi. Fungal Genetics and Biology 24, 86.

Colotelo, N. (1978): Fungal Exudates. Canadian Journal of Microbiology 24, 1173.

Colpaert, J. V., Verstuyft, I. (1999): The Ingestad concept in ectomycorrhizal research: Possibilities and limitations. Physiologia Plantarum 105, 233.

Cosgrove, D. J. (1977): Microbial transformations in the phosphorus cycle. In M. Alexander: Advances in Microbial Ecology. Plenum Press: New York., 95-135.

Cowling, R. M., Rundel, P. W., Lamont, B. B., Arroyo, M. K., Arianoutsou, M. (1996): Plant diversity in Mediterranean-climate regions. Trends in Ecology \& Evolution 11, 362.

Cox, G., Moran, K. J., Sanders, F., Nockolds, C., Tinker, P. B. (1980): Translocation and transfer of nutrients in vesicular-arbuscular mycorrhizas .3. polyphosphate granules and phosphorus translocation. New Phytologist 84, 649.

Cramer, C. L., Davis, R. H. (1984): Polyphosphate-cation interaction in the amino acidcontaining vacuole of Neurospora-crassa. Journal of Biological Chemistry 259, 5152.

Cribb, P. J., Lell, S. P., Dixon, K. W., Barrett, R. L. (2003): Orchid conservation a global perspective. In K. W. Dixon, S. P. Kell, R. L. Barrett and P. J. Cribb: Orchid conservation. Natural History Publications: Borneo: Kota Kinabalu, Sabah

Cumming, J. R, Weinstein, L. H. (1990): Utilization of AIPO4 as a phosphorus source by ectomycorrhizal Pinus rigida Mill. seedlings. New Phytologist 116, 99.

Dalal, R.C. (1977): Soil organic phosphorus. In B. N.C.: Advances in AgronomyAcadamic Press Inc.: London.

Dickson, S. (2004): The Arum-Paris continuum of mycorrhizal symbioses. New Phytologist 163, 187.

Dressler, R. L. (1993): Phylogeny and classification of the orchid family, Portland, OR, USA.

Dressler, R. L. (2005): How many orchid species? Selbyana, 155.

Dunne, M., Fitter, A. (1989): The phosphorus budget of a field-grown strawberry (Fragraria $x$ ananassa cv. Hapil.) crop: evidence for mycorrhizal contribution. Annals of Applied Biology 144, 185.

Ezawa, T., Kuwahara, S., Sakamoto, K., Yoshida, T., Saito, M. (1999): Specific inhibitor and substrate specificity of alkaline phosphatase expressed in the symbiotic phase of the arbuscular mycorrhizal fungus, Glomus etunicatum. Mycologia 91, 636.

Ezawa, T., Smith, S. E., Smith, A. F. (2002): P metabolism and transport in AM fungi. Plant and Soil 244, 221. 
Garcia, K., Haider, M. Z., Delteil, A., Corratgé-Faillie, C., Conéjero, G., Tatry, M.-V., Becquer, A., Amenc, L., Sentenac, H., Plassard, C. (2013): Promoter-dependent expression of the fungal transporter HcPT1. 1 under Pi shortage and its spatial localization in ectomycorrhiza. Fungal Genetics and Biology 58, 53.

Gerlitz, T. G. M., Gerlitz, A. (1997): Phosphate uptake and polyphosphate metabolism of mycorrhizal and non-mycorrhizal roots of pine and of Suillus bovinus at varying external pH measured by in vivo ${ }^{31} \mathrm{P}-\mathrm{NMR}$. Mycorrhiza 7, 101.

Gerlitz, T. G. M., Werk, W. B. (1994): Investigations on phosphate-uptake and polyphosphate metabolism by mycorrhized and nonmycorrhized roots of beech and pine as investigated by in-vivo- ${ }^{31}$ P-NMR. Mycorrhiza 4, 207.

Gianinazzi-Pearson, V., Gianinazzi, S. (1983): The physiology of vesicular-arbuscular mycorrhizal roots. Plant and Soil 71, 197.

Gibson, B. R., Mitchell, D. T. (2004): Nutritional influences on the solubilization of metal phosphate by ericoid mycorrhizal fungi. Mycological research 108, 947.

Girlanda, M., Segreto, R., Cafasso, D., Liebel, H. T., Rodda, M., Ercole, E., Cozzolino, S., Gebauer, G., Perotto, S. (2011): Photosynthetic mediterranean meadow orchids feature partial mycoheterotrophy and specific mycorrhizal associations. American Journal of Botany 98, 1148.

Grellier, B., Strullu, D. G., Martin, F., Renaudin, S. (1989): Synthesis in vitro, microanalysis and ${ }^{32} \mathrm{P}-\mathrm{NMR}$ study of metachromatic granules in birch mycorrhizas. New Phytologist 112, 49.

Griesbach, R. (2002): Development of Phalaenopsis orchids for the mass-market. In J. Janick and A. Whipkey: Trends in new crops and new uses. ASHS Press: Alexandria, VA, USA,

Grunwald, U., Guo, W., Fischer, K., Isayenkov, S., Ludwig-Mueller, J., Hause, B., Yan, X., Kuester, H., Franken, P. (2009): Overlapping expression patterns and differential transcript levels of phosphate transporter genes in arbuscular mycorrhizal, P-ifertilised and phytohormone-treated Medicago truncatula roots. Planta 229, 1023.

Hadley, G., Williamson, B. (1972): Features of mycorrhizal infection in some Malayan orchids. New Phytologist 71, 1111.

Hammer, E. C., Pallon, J., Wallander, H., Olsson, P. A. (2011): Tit for tat? A mycorrhizal fungus accumulates phosphorus under low plant carbon availability. FEMS Microbiology Ecology 76, 236.

Handreck, K. A. (1997): Phosphorus requirements of Australian native plants. Australian Journal of Soil Research 35, 241.

Harley, J. L., Loughman, B. C. (1963): The uptake of phosphate by excised mycorrhizal roots of the beech. IX. The nature of the phosphate compounds passing into the host. New Phytologist 62, 350.

Harold, F. M. (1966): Inorganic polyphosphates in biology - structure metabolism and function. Bacteriological Reviews 30, 772.

Harrison, M. J. (1999): Biotrophic interfaces and nutrient transport in plant fungal symbioses. Journal of Experimental Botany 50, 1013.

Hedley, M. J., Stewart, J. W. B., Chauhan, B. S. (1982): Changes in inorganic and organic soil- phosphorous fractions induced by cultivation practices and by laboratory incubations. Soil Science Society of America Journal 46, 970.

Heinrich, P. A., Patrick, J. W. (1986): Phosphorus acquisition in the soil root-system of Eucalyptus-pilularis Smith seedlings. 2. The effect of Ectomycorrhizas on seedling phosphorus and dry-weight acquisition. Australian Journal of Botany 34, 445. 
Hetrick, B. A. D., Wilson, G. W. T., Hertnett, D. C. (1989): Relationship between mycorrhizal dependence and competitive ability of two tallgrass prairie grasses. Canadian Journal of Botany 67, 2608.

Hopper, S. D. (2009): OCBIL theory: towards an integrated understanding of evolution, ecology and conservation of biodiversity on old, climatically buffered, infertile landscapes. Plant Soil 322, 49.

Hopper, S. D. (2009): OCBIL theory: towards an integrated understanding of the evolution, ecology and conservation of biodiversity on old, climatically buffered, infertile landscapes. Plant and Soil 322, 49.

Hyde, G. J., Ashford, A. E. (1997): Vacuole motility and tubule-forming activity in Pisolithus tinctorius hyphae are modified by environmental conditions. Protoplasma 198, 85.

Jones, M. D., Durall, D. M., Tinker, P. B. (1998): Comparison of arbuscular and ectomycorrhizal Eucalyptus coccifera: growth response, phosphorus uptake efficiency and external hyphal production. New Phytologist 140, 125.

Jordan, C., Golley, F., Hall, J. (1980): Nutrient scavenging of rainfall by the canopy of an Amazonian rain-forest. Biotropica 12, 61.

Klionsky, D. J., Herman, P. K., Emr, S. D. (1990): The fungal vacuole - composition, function, and biogenesis. Microbiological Reviews 54, 266.

Kornberg, A., Rao, N. N., Ault-Riche, D. (1999): Inorganic polyphosphate: A molecule of many functions. Annual Review of Biochemchemistry 68, 89.

Lambers, H., Clements, J. C., Nelson, M. N. (2013): How a phosphorus-acquisition strategy based on carboxylate exudation powers the success and agronomic potential of Lupines (Lupinus, Fabaceae). American Journal of Botany 100, 263.

Lambers, H., Juniper, D., Cawthray, G. R., Veneklaas, E. J., Martínez-Ferri, E. (2002): The pattern of carboxylate exudation in Banksia grandis (Proteaceae) is affected by the form of phosphate added to the soil. Plant and Soil 238, 111.

Lambers, H., Raven, J. A., Shaver, G. R., Smith, S. E. (2008): Plant nutrient-acquisition strategies change with soil age. Trends in Ecology \& Evolution 23, 95.

Landeweert, R., Hoffland, E., Finlay, R. D., Kuyper, T. W., van Breemen, N. (2001): Linking plants to rocks: ectomycorrhizal fungi mobilize nutrients from minerals. Trends in Ecology \& Evolution 16, 248.

Leake, J. R. (1994): The biology of mycoheterotrophic (saprophytic) plants. New Phytologist 127, 171.

Leake, J. R.,. McKendrick, S. L., Bidartondo, M., Read, D. J. (2004): Symbiotic germination and development of the myco-heterotroph Monotropa hypopitys in nature and its requirement for locally distributed Tricholoma spp. New Phytologist $163,405$.

Lendenmann, M., Thonar, C., Barnard, R. L., Salmon, Y., Werner, R. A., Frossard, E., Jansa, J. (2011): Symbiont identity matters: carbon and phosphorus fluxes between Medicago truncatula and different arbuscular mycorrhizal fungi. Mycorrhiza 21, 689.

Lewis, D. H. (1973): Conceps in fungal nutrition and origin of biotrophy. Biological Reviews of the Cambridge Philosophical Society 48, 261.

Li, L.-H. (1998): Throughfall and stemflow nutrient depositions to soil in a subtropical evergreen broad-leaved forest in the Wuyi Mountains. Journal of Environmental Sciences (China) 10, 426. 
Liebel, H. T., Bidartondo, M., Preiss, K., Segreto, R., Stöckel, M., Rodda, M., Gebauer, G. (2010): C and N stable isotope signature reveal constraints to nutritional modes in orchids from the mediterranean and macronesia American Journal of Botany 97, 903.

Liltved, W. R., Johnson, S. D. (2012): The Cape Orchids, Cape Town, South Africa.

Lindahl, B., Olsson, S. (2004): Fungal translocation - creating and responding to environmental heterogeneity. Mycologist 18, 79.

Lindahl, B., Stenlid, J., Olsson, S., Finlay, R. (1999): Translocation of ${ }^{32} \mathrm{P}$ between interacting mycelia of a wood-decomposing fungus and ectomycorrhizal fungi in microcosm systems. New Phytologist 144, 183.

Lindahl, B., Finlay, R., Olsson, S. (2001): Simultaneous, bidirectional translocation of ${ }^{32} \mathrm{P}$ and ${ }^{33} \mathrm{P}$ between wood blocks connected by mycelial cords of Hypholoma fasciculare. New Phytologist 150, 189.

Lindsay, A. M. (1985): Are australian soils different?: Dodson, J. R. And M. Westoby, 8398.

Lodge, D. J., McDowell, W. H., McSwiney, C. P. (1994): The importance of nutrient pulses in tropical forests. Trends in Ecology \& Evolution 9, 384.

Loughman, B. C., Ratcliffe, R. G. (1984): Nuclear magnetic resonance and the study of plants. Praeger, New York. p. 241-283.

Marschner, H., Dell, B. (1994): Nutrient-uptake in mycorrhizal symbiosis. Plant and Soil 159, 89.

Martin, F., Canet, D., Rolin, D., Marchal, J. P., Larher, F. (1983): Phosphorus-31 nuclear magnetic resonance study of polyphosphate metabolism in intact ectomycorrhizal fungi. Plant and Soil 71, 469.

Martin, F., Marchal, J. P., Timinska, A., Canet, D. (1985): The metabolism and physical state of polyphosphates in ectomycorrhizal fungi - a ${ }^{31} \mathrm{P}$ nuclear magneticresonance study. New Phytologist 101, 275.

McColl, J. G. (1970): Properties of some natural waters in a tropical wet forest of CostaRica. Bioscience 20, 1096.

Merckx, V., Freudenstein, J. V. (2010): Evolution of mycoheterotrophy in plants: a phylogenetic perspective. New Phytologist 185, 605.

Merryweather, J., Fitter, A. (1995): Phosphorus and budgets - mycorrhizal contribution in Hyacinoides non-scribta (L) Chouard ex Rothm under natural conditions. New Phytologist 129, 619.

Mousain, D., Salsac, L. (1985): Utilisation du phytate et activite's phosphatases acides chez Pisolithus tinctorius, basidiomyce` te mycorhizien. Physiol. Veg 24, 193.

Moyersoen, B., Alexander, I. J., Fitter, A. H. (1998): Phosphorus nutrition of ectomycorrhizal and arbuscular mycorrhizal tree seedlings from a lowland tropical rain forest in Korup National Park, Cameroon. Journal of Tropical Ecology 14, 47.

Mulligan, D. R., Patrick, J. W. (1985): Phosphorus and carbon budgets of Eucalyptus pilularis Smith seedlings during their cotyledonary phase of growth. Australian Journal of Plant Physiology 12, 535.

Munkvold, L., Kjoller, R., Vestberg, M., Rosendahl, S., Jakobsen, I. (2004): High functional diversity within species of arbuscular mycorrhizal fungi. New Phytologist 164, 357.

Myers, N., Mittermeier, R. A., Mittermeier, C. G., da Fonseca, G. A. B., Kent, J. (2000): Biodiversity hotspots for conservation priorities. Nature 403, 853. 
Nagy, R., Drissner, D., Amrhein, N., Jakobsen, I., Bucher, M. (2009): Mycorrhizal phosphate uptake pathway in tomato is phosphorus-repressible and transcriptionally regulated. New Phytologist 181, 950.

Oberson, A., Joner, E. J (2005): Microbial turnover of phosphorus in soil. In Turner, B. L., Frossard, E., Baldwin, D. S.: Organic phosphorus in the environment. CABI: Wallingford, 133-164.

Olsson, P. A., Wallander, H. (1998): Interactions between ectomycorrhizal fungi and the bacterial community in soils amended with various primary minerals. Fems Microbiology Ecology 27, 195.

Orians, G. H., Milewski, A. V. (2007): Ecology of Australia: the effects of nutrient-poor soils and intense fires. Biological Reviews 82, 393.

Orlovich, D. A., Ashford, A. E. (1993): Polyphosphate granules are an artefact ofspecimen preparation in ectomycorrhizal fungus Pisolithus tinctorius. Protoplasma 173, 91.

Orlovich, D. A., Ashford, A. E. (1994): Structure and development of the dilospore septum in Pisolithus tinctorius. Protoplasma 178, 66.

Orłowska, E., Mesjasz-Przybyłowicz, J., Przybyłowicz, W., Turnau, K. (2008): Nuclear microprobe studies of elemental distribution in mycorrhizal and non-mycorrhizal roots of Ni-hyperaccumulator Berkheya coddii. X-Ray Spectrometry 37, 129.

Pate, J. S. (1994): The mycorrhizal association - just one of many nutrient acquiring specializations in natural ecosystems. Plant and Soil 159, 1.

Pearson, J. N., Jakobsen, I. (1993): The relative contribution of hyphae and roots to phosphorus uptake by arbuscular mycorrhizal plants, measured by dual labeling with P-32 and P-33. New Phytologist 124, 489.

Pfeffer, P. E., Bago, B., Shachar-Hill, Y. (2001): Exploring mycorrhizal function with NMR spectroscopy. New Phytologist 150, 543.

Plassard, C., Dell, B, (2010): Phosphorus nutrition of mycorrhizal trees. Tree Physiology 30, 1129.

Plassard, C., Louche, J., Ali, M. A., Duchemin, M., Legname, E., Cloutier-Hurteau, B. (2011): Diversity in phosphorus mobilisation and uptake in ectomycorrhizal fungi. Annals of Forest Science 68, 33.

Preiss, K., Adam, I. K. U., Gebauer, G. (2010): Irradiance governs exploitation of fungi: fine-tuning of carbon gain by two partially myco-heterotrophic orchids. Proceedings of the Royal Society B-Biological Sciences 277, 1333.

Pridgeon, A. M., Cribb, P. J., Chase, M. W., Rasmussen, F. (1999 ): Genera Orchidacearum. Oxford University Press, Kettering, UK.

Ramsay, R. R., Sivasithamparam, K., Dixon, K. W. (1986): Patterns of infection and endophytes associated with Western Australian orchids. Lindleyana 1, 203.

Rasmussen, H. N. (1995): Terrestrial Orchids: from seed to mycotrophic plant. Cambrige University Press, Cambridge, UK.

Rasmussen, H. N, Rasmussen, F. N. (2009): Orchid mycorrhiza: implications of a mycophagous life style. Oikos 118, 334.

Rasmussen, N., Lloyd, D. C., Ratcliffe, R. G., Hansen, P. E., Jakobsen I. (2000): ${ }^{31}$ P NMR for the study of $P$ metabolism and translocation in arbuscular mycorrhizal fungi. Plant and Soil 226, 245.

Read, D.J. (1996): The Structure and Function of the Ericoid Mycorrhizal Root. Annals of Botany 77, 365. 
Reich, P. (2015): Phosphorus Retention Potential Map. United States Department of Agriculture: Natural Resources Conservation Service Soils

Richardson, A. E., George, T. S., Hens, M., Simpson, R. J. (2005): Utilization of soil organic phosphorus by higher plants. In Turner, B. L., Frossard, E., Baldwin, D. S.: Organic phosphorus in the environment. CABI: Wallingford, 165-184.

Richardson, K. A., Peterson, R. L., Currah, R. S. (1992): Seed reserves and early symbiotic protocorm development of Platanthera hyperborea (Orchidaceae). Canadian journal of botany 70, 291.

Robinson, D. (1994): The responses of plants to non-uniform supplies of nutrients. New Phytologist 127, 635.

Schachtman, D. P., Reid, R. J., Ayling, S. M. (1998): Phosphorus uptake by plants: From soil to cell. Plant Physiology 116, 447.

Schmidt, G., Stuntz, S., Zotz, G. (2001): Plant size - an ignored parameter in epiphyte ecophysiology. . Plant Ecology 153, 65.

Schüßler, A., Schwarzott, D., Walker, C. (2001): A new fungal phylum, the Glomeromycota: phylogeny and evolution. Mycological Research 105, 1413.

Selmants, P. C., Hart, S. C. (2010): Phosphorus and soil development: Does the Walker and Syers model apply to semiarid ecosystems? Ecology 91, 474.

Serrigny, J., Dexheimer, J. (1985): Étude ultrastructurale des endomycorhizes d'une orchidée tropicale: Epidendrum ibaguense. II. Localisation des ATPases et des nucleosides diphosphotases. Cytologia 50, 779.

Shane, M. W., McCully, M. E., Lambers, H. (2004): Tissue and cellular phosphorus storage during development of phosphorus toxicity in Hakea prostrata (Proteaceae). Journal of Experimental Botany 55, 1033.

Shirahama, K., Yazaki, Y., Sakano, K., Wada, Y., Ohsumi, Y. (1996): Vacuolar function in the phosphate homeostasis of the yeast Saccharomyces cerevisiae. Plant and Cell Physiology 37, 1090.

Shoji, J.-Y., Arioka, M., Kitamoto, K. (2006): Possible involvement of pleiomorphic vacuolar networks in nutrient recycling in filamentous fungi. Autophagy 2, 226.

Smeck, N. E. (1985): Phosphorus dynamics in soils and landscapes. Geoderma 36, 185.

Smith, F. A., Smith, S. E. (1989): Membrane-transport at the biotrophic interface - an overview. Australian Journal of Plant Physiology 16, 33.

Smith, S. E. (1967): Carbohydrate translocation in orchid mycorrhizas. New Phytologist 66, 371.

Smith, S. E., Gianinazzi-Pearson, V. (1988): Physiological interactions between symbionts in Vesicular-Arbuscular mycorrhizal plants. Annual Review of Plant Physiology and Plant Molecular Biology 39, 221.

Smith, S. E., Gianinazzi-Pearson, V., Koide, R., Cairney, J. W. G. (1994): Nutrient transport in mycorrhizas - structure, physiology and consequences for efficiency of the symbiosis. Plant and Soil 159, 103.

Smith, S. E., Read, D. J. (1997): Mycorrhiyal Symbiosis. Academic Press Ltd, London, UK.

Smith, S. E., Read, D. J. (2008): Mycorrhizal Symbiosis. Academic Press Ltd, London, UK.

Smith, S. E., Smith, F. A. (1990): Structure and function of the interfaces in biotrophic symbioses as they relate to nutrient transport. New Phytologist 114, 1. 
Smith, S. E., Smith, F. A., Jakobsen, I. (2003): Mycorrhizal fungi can dominate phosphate supply to plants irrespective of growth responses. Plant Physiology 133, 16.

Smith, S. E., Jakobsen, I., Gronlund, M., Smith, F. A. (2011): Roles of Arbuscular Mycorrhizas in Plant Phosphorus Nutrition: Interactions between Pathways of Phosphorus Uptake in Arbuscular Mycorrhizal Roots Have Important Implications for Understanding and Manipulating Plant Phosphorus Acquisition. Plant Physiology 156, 1050.

Smith, S. E., Smith. F. A. (2011): Roles of Arbuscular Mycorrhizas in Plant Nutrition and Growth: New Paradigms from Cellular to Ecosystem Scales. In S. S. Merchant, W. R. Briggs and D. Ort: Annual Review of Plant Biology, 227-250.

Solaiman, M. Z., Ezawa, T., Kojima, T., Saito, M. (1999): Polyphosphates in intraradical and extraradical hyphae of an arbuscular mycorrhizal fungus, Gigaspora margarita. Applied and Environmental Microbiology 65, 5604.

Sommer, J., Pausch, J., Brundrett, M. C., Dixon, K. W., Bidartondo, M. I., Gebauer, G. (2012): Limited carbon and mineral nutrient gain from mycorrhizal fungi by adult Australian orchids American Journal of Botany 99, 1133.

Spohn, M., Kuzyakov, Y. (2013a): Distribution of microbial- and root-derived phosphatase activities in the rhizosphere depending on $\mathrm{P}$ availability and $\mathrm{C}$ allocation Coupling soil zymography with ${ }^{14} \mathrm{C}$ imaging. Soil Biology and Biochemistry 67, 106.

Spohn, M., Kuzyakov ,Y. (2013b): Phosphorus mineralization can be driven by microbial need for carbon. Soil Biology and Biochemestry 61, 69.

Stenlid, G. (1958): Salt losses and redistribution of salts in higher plants: Encyclopedia of Plant Physiology IV. Springer Berlin Heidelberg, 615-637.

Strullu, D. G., Gourret, J. P., Garrec, J. P., Fourcy, A. (1981): Ultrastructure and electronprobe microanalysis of the metachromatic vacuolar granules occurring in Taxus mycorrhizas. New Phytologist 87, 537.

Strullu, D. G., Harley, J. L., Gourret, J. P., Garrec, J. P. (1982): Ultrastructure and microanalysis of the polyphosphate granules of the ectomycorrizas of FagusSylvatica. New Phytologist 92, 417.

Tatry, M.-V., Kassis, E. E., Lambilliotte, R., Corratgé, C., van Aarle, I., Amenc, L. K., Alary, R., Zimmermann, S., Sentenac, H., Plassard, C. (2009): Two differentially regulated phosphate transporters from the symbiotic fungus Hebeloma cylindrosporum and phosphorus acquisition by ectomycorrhizal Pinus pinaster. The Plant Journal 57, 1092.

Tawaraya, K., Naito, M., Wagatsuma, T. (2006): Solubilization of insoluble inorganic phosphate by hyphal exudates of arbuscular mycorrhizal fungi. Journal of plant nutrition 29, 657.

Taylor, J. H., Peterson, C. A. (2005): Ectomycorrhizal impacts on nutrient uptake pathways in woody roots. New Forests 30, 203.

Tedersoo, L., Smith, M. E. (2013): Lineages of ectomycorrhizal fungi revisited: foraging strategies and novel lineages revealed by sequences from belowground. Fungal Biology Reviews 27, 83.

Terpitz, U., Kothe, E. (2012): Diversity and adaptation of soil fungi in an ecosystem with contamination originating from a phosphate fertilizer plant. Journal of applied botany and food quality 80, 187.

Těšitelová, T., Těšitel, J., Jersáková, J., Říhová, G., Selosse, M.-A. (2012): Symbiotic germination capability of four Epipactis species (Orchidaceae) is broader than expected from adult ecology. American Journal of Botany 99, 1020. 
Thomson, B. D., Clarkson, D. T., Brain, P. (1990): Kinetics of phosphorus uptake by the germ-tubes of the Vesicular Arbuscular mycorrhizal fungus, Gigaspora-margarita. New Phytologist 116, 647.

Tinker, P. B. (1975): Effects of vesicular-arbuscular mycorrhizas on higher plants. Symposia of the Society for Experimental Biology 29, 325.

Turkington, A. V., Phillips, J. D., Campbell, S. W. (2005): Weathering and landscape evolution. Geomorphology 67, 1.

Turner, B. L. (2008): Resource partitioning for soil phosphorus: a hypothesis. Journal of Ecology 96, 698.

Viereck, N., Hansen, P. E., Jakobsen, I. (2004): Phosphate pool dynamics in the arbuscular mycorrhizal fungus Glomus intraradices studied by in vivo ${ }^{31} \mathrm{P}$ NMR spectroscopy. New Phytologist 162, 783.

Wallander, H. (2000): Uptake of $P$ from apatite by Pinus sylvestris seedlings colonised by different ectomycorrhizal fungi. Plant and Soil 218, 249.

Wanek, W., Zotz, G. (2011): Are vascular epiphytes nitrogen or phosphorus limited? A study of plant ${ }^{15} \mathrm{~N}$ fractionation and foliar $\mathrm{N}$ : P stoichiometry with the tank bromeliad Vriesea sanguinolenta. New Phytologist 192, 462.

Wasaki, J., Yamamura, T., Shinano, T., Osaki, M. (2003): Secreted acid phosphatase is expressed in cluster roots of lupin in response to phosphorus deficiency. Plant and Soil 248, 129.

White, J. A., Brown, M. F. (1974): Ultrastructure and X-ray analysis of phosphorus granules in a vesicular-arbuscular mycorrhizal fungus. Canadian Journal of Botany 57, 2812.

Wu, B., Maruyama, H., Teramoto, M., Hogetsu, T. (2012): Structural and functional interactions between extraradical mycelia of ectomycorrhizal Pisolithus isolates. New Phytologist 194, 1070.

Xu, G. H., Chague, V., Melamed-Bessudo, C., Kapulnik, Y., Jain, A., Raghothama, K. G., Levy, A. A., Silber, A. (2007): Functional characterization of LePT4: a phosphate transporter in tomato with mycorrhiza-enhanced expression. Journal of Experimental Botany 58, 2491.

Yagame, T., Orihara, T., Selosse, M. A., Yamato, M., Iwase, K. (2012): Mixotrophy of Platanthera minor, an orchid associated with ectomycorrhiza-forming Ceratobasidiaceae fungi. New Phytol 193, 178.

Yagame, T., Yamato, M. (2013): Mycoheterotrophic growth of Cephalanthera falcata (Orchidaceae) in tripartite symbioses with Thelephoraceae fungi and Quercus serrata (Fagaceae) in pot culture condition. J Plant Res 126, 215.

Zhu, Y. G., Cavagnaro, T. R., Smith, S. E., Dickson, S. (2001): Backseat driving? Accessing phosphate beyond the rhizosphere - depletion zone. Trends in Plant Science 6, 194.

Zotz, G. (1999): What are backshoots good for? Seasonal changes in mineral, carbohydrate and water content of different organs of the epiphytic orchid, Dimerandra emarginata. Annals of Botany 84, 791.

Zotz, G., Hietz, P. (2001): The physiological ecology of vascular epiphytes: current knowledge, open questions. Journal of Experimental Biology 52, 2067.

Zotz, G., Richter, A. (2006): Changes in carbohydrate and nutrient contents throughout a reproductive cycle indicate that phosphorus is a limiting nutrient in the epiphytic bromeliad, Werauhia sanguinolenta. Annals of Botany 97, 745. 
Zotz, G., Winkler, U. (2013): Aerial roots of epiphytic orchids: the velamen radicam and its role in water and nutrient uptake. Oecologia 171, 733. 


\section{Study 4}

\subsection{Different responses of ash and beech on nitrate versus ammonium leaf labeling}

JANINE SOMMER ${ }^{1 *}$, MICHAELA DIPPOLD ${ }^{2}$, YAKOV KUZYAKOV $^{1,2}$

Submitted to Journal of Plant Nutrition and Soil Science (Minor Revision)

${ }^{1}$ Georg-August-University Göttingen, Soil Science of Temperate Ecosystems, Büsgenweg 2, 37077 Göttingen, Germany

${ }^{2}$ Georg-August-University Göttingen, Agricultural Soil Science, Büsgenweg 2, 37077 Göttingen, Germany

*corresponding author

Department of Soil Science of Temperate Ecosystems, Georg-August-University Göttingen, 37077 Göttingen, Germany

Phone: + 49(0)157 $73857055 \quad F a x+49(0) 551393310$

email: sommer.janine@yahoo.de 


\section{Abstract}

The effects of tree species on the $\mathrm{N}$ cycle in forest systems are still under debate. However, contradicting results of different ${ }^{15} \mathrm{~N}$ labeling techniques of trees and $\mathrm{N}$ tracers in the individual studies hamper a generalized mechanistic view. Therefore, we compared $\mathrm{Ca}\left({ }^{15} \mathrm{NO}_{3}\right)_{2}$ and ${ }^{15} \mathrm{NH}_{4} \mathrm{Cl}$ leaf-labeling method to investigate 1) $\mathrm{N}$ allocation patterns from aboveground to belowground, 2) the cycles of $\mathrm{N}$ in soil-plant systems and 3) to allow the production of highly ${ }^{15} \mathrm{~N}$ enriched litter for subsequent decomposition studies.

20 beeches (Fagus sylvatica) and 20 ashes (Fraxinus excelsior) were ${ }^{15} \mathrm{~N}$ pulse labeled from aboveground with $\mathrm{Ca}\left({ }^{15} \mathrm{NO}_{3}\right)_{2}$ and 40 beeches and 40 ashes were ${ }^{15} \mathrm{~N}$ pulse labeled from aboveground with ${ }^{15} \mathrm{NH}_{4} \mathrm{Cl}$. ${ }^{15} \mathrm{~N}$ was quantified in tree compartments (leaves, stem, roots) and in soil after eight days.

Beech and ash incorporated generally more ${ }^{15} \mathrm{~N}$ from the applied ${ }^{15} \mathrm{NH}_{4} \mathrm{Cl}$ compared to $\mathrm{Ca}\left({ }^{15} \mathrm{NO}_{3}\right)_{2}$ in all measured compartments, except for ash leaves. Ash had highest ${ }^{15} \mathrm{~N}$ incorporation (45\% of the applied with $\left.\mathrm{Ca}\left({ }^{15} \mathrm{NO}_{3}\right)_{2}\right)$ in its leaves. Both tree species kept over $90 \%$ of all fixed ${ }^{15} \mathrm{~N}$ from $\mathrm{Ca}\left({ }^{15} \mathrm{NO}_{3}\right)$ in their leaves, whereas only $50 \%$ of the ${ }^{15} \mathrm{~N}$ from the ${ }^{15} \mathrm{NH}_{4} \mathrm{Cl}$ tracer remained in the leaves and $50 \%$ were allocated to stem, roots and soil. There was no damage of the leaves by both salts, and thus both ${ }^{15} \mathrm{~N}$ tracers enable longterm labeling in situ field studies on $\mathrm{N}$ rhizodeposition and allocation in soils. Nonetheless the ${ }^{15} \mathrm{~N}$ incorporation by both salts was species specific: the leaf labeling with ${ }^{15} \mathrm{NH}_{4} \mathrm{Cl}$ results in a more homogenous distribution between the tree compartments in both tree species and therefore, ${ }^{15} \mathrm{NH}_{4} \mathrm{Cl}$ is more appropriate for allocation studies. The leaf labeling with $\mathrm{Ca}\left({ }^{15} \mathrm{NO}_{3}\right)_{2}$ is a suitable tool to produce highly enriched ${ }^{15} \mathrm{~N}$ leaf litter for further long term in situ decomposition and turnover studies.

Key-words: $\mathrm{Ca}\left({ }^{15} \mathrm{NO}_{3}\right)_{2}$ labeling, ${ }^{15} \mathrm{NH}_{4} \mathrm{Cl}$ labeling, nitrogen cycles, tree rhizodeposition, species effects, deciduous forest. 


\subsubsection{Introduction}

Plant-available $N$ in soil originates from various sources: microbially fixed atmospheric $N_{2}$, atmospheric $\mathrm{N}$ deposition, mineralization of plant litter and root exudates and mineralization of soil organic matter (Millard and Grelet, 2010). N cycling in forest ecosystems has been intensively studied during the past decades, especially regarding the expected climate change scenarios (Heinrich et al., 2015) and ${ }^{15} \mathrm{~N}$ labeling techniques are frequently used to study $\mathrm{N}$ transformations and allocation in agroecosystems, but seldom in forest ecosystems. Studies on $\mathrm{N}$ rhizodeposition in deciduous forest ecosystems are still scarce and deliver contrasting results (Brumme et al., 1992; Hertenberger and Wanek, 2004).

Investigating $\mathrm{N}$ rhizodeposition requires ${ }^{15} \mathrm{~N}$ labeling of the tree from aboveground. One reason for the high variability in results on $\mathrm{N}$ allocation is the use of different ${ }^{15} \mathrm{~N}$ labeling methods of plants (Jones et al., 2009). Three labeling approaches are frequently used to investigate $\mathrm{N}$ rhizodeposition: 1) shoot labeling, 2) leaf labeling and 3) split root system. Ammonium nitrate or urea have been used for the shoot labeling (also called wick method) (Glaser et al., 2012; Mayer et al., 2003; Russell and Fillery, 1996; Wichern et al., 2011; Yasmin et al., 2006). For example, Glaser et al. (2012) used ${ }^{15} \mathrm{~N}$ shoot labeling by drilling a hole through the stem and inserted a fiber glass wick, covered with a PVC tube at both sides of the hole. The cut surface between hole and wick was sealed with PVC glue and the glass fiber wicks were saturated with sterile water and connected with a reservoir containing the ${ }^{15} \mathrm{NH}_{4}{ }^{15} \mathrm{NO}_{3}$ tracer solution. The produced labeled plant material was then used to trace and quantify $\mathrm{N}$ from litter decomposition, such as in other studies (Benesch et al., 2015; Bimuller et al., 2013; Schmidt and Scrimgeour, 2001). Leguminous trees stem-labeled with $\mathrm{K}^{15} \mathrm{NO}_{3}$ solution showed limited ${ }^{15} \mathrm{~N}$ transfer to associated grass in an agroforestry system and indicated that transfer of the added ${ }^{15} \mathrm{~N}$ was limited in space (i.e., up to $1 \mathrm{~m}$ from the trees) and delayed in time (i.e., ${ }^{15} \mathrm{~N}$ reached the tree roots more than 3 months after labeling), which prevented estimation based on the stem- ${ }^{15} \mathrm{~N}$ labeling method (Sierra and Daudin, 2010). However injecting ${ }^{15} \mathrm{~N}$ directly into the vessel elements also requires special equipment and foliar fertilization delivers the nutrients directly to the leaves and increases $\mathrm{N}$ use efficiency. Therefore ${ }^{15} \mathrm{~N}$ foliar application could be a useful tool for labeling tree leaf material ( $T a$ et al., 1989). Urea and $\mathrm{NH}_{4} \mathrm{NO}_{3}$ have frequently been used for leaf labeling to investigate the distribution and recycling of canopy $\mathrm{N}$ storage reserves (Ayala et al., 2014). Ayala et al. (2014) bagged cherry trees to isolate them from the rest of the soil and then sprayed a solution of ${ }^{15} \mathrm{~N}$-urea onto the leaves. Their approach is similar to the method used by Zeller et al. (1998) and d'Annunzio et al. 
(2008), who sprayed beech trees also with ${ }^{15} \mathrm{~N}$ urea to produce ${ }^{15} \mathrm{~N}$-labeled litter. ${ }^{15} \mathrm{~N}$ litter labeling experiments conducted in two European forests revealed after a decade that $60 \%$ of the ${ }^{15} \mathrm{~N}$ tracer from the litter was retained in soil aggregates, while plant debris still contained $40 \%$ of the tracer (Hatton et al., 2012). Varying concentrations of ${ }^{15} \mathrm{NH}_{4}{ }^{+}$and ${ }^{15} \mathrm{NO}_{3}{ }^{-}$were also used for leaf labeling to study the preferential uptake of $\mathrm{NH}_{4}{ }^{+}$and $\mathrm{NO}_{3}{ }^{-}$ by aboveground parts of beech trees and as simulated rain on red maple and white oak and revealed that the foliar uptake of ${ }^{15} \mathrm{NH}_{4}{ }^{+}$from the tracer by deciduous tree leaves exceeded the uptake of $\mathrm{NO}_{3}{ }^{-}$(Brumme, Leimcke, Matzner, 1992; Garten and Hanson, 1990).

The $\mathrm{N}$ fluxes in the xylem of trees are regulated by three processes: remobilization from internal reserves, root uptake of $\mathrm{N}$ from the soil, and phloem-xylem recycling (Dambrine et al., 1995; Grassi et al., 2003). Species-specific patterns of $C$ and $N$ allocation in the tree compartments might be due to differences in remobilization and recycling processes and, therefore, differences in the amount of rhizodeposition into the soil (Sommer et al., 2016). However, the labeling of grey alder leaves following root fertilization and leaf fertilization with either ${ }^{15} \mathrm{NH}_{4}{ }^{+}$or ${ }^{15} \mathrm{NO}^{-}$revealed that root fertilization gave better labeling efficiency, uniformity and repeatability than leaf labeling in both ${ }^{15} \mathrm{~N}$ labeling forms (GonzalezPrieto et al., 1995). $\left(\mathrm{NH}_{4}\right)_{2} \mathrm{SO}_{4}$ and $\mathrm{KNO}_{3}$ have been used in the split root system, where the root systems of one seedling are split between two soil chambers. Labeling one soil chamber with a ${ }^{15} \mathrm{~N}$-enriched $\mathrm{N}$ source enables observing the $\mathrm{N}$ loss from the portion of the root system growing in the unlabeled soil chamber (Jensen, 1996; Sawatsky and Soper, 1991; Schmidtke, 2005). It can be concluded that a tracer including $\mathrm{NH}_{4}^{+}$will take up higher amount of $\mathrm{N}$ and might therefore have advantages in further leaf labeling experiments.

Picea abies was labeled with ${ }^{15} \mathrm{NO}_{3}{ }^{-}$and ${ }^{15} \mathrm{NH}_{4}{ }^{+}$through soil application addressing the question of preferential $\mathrm{N}$ source uptake and investigated $94 \%$ recovery for the applied ${ }^{15} \mathrm{NH}_{4}{ }^{+}$and $100 \%$ for the applied ${ }^{15} \mathrm{NO}_{3}{ }^{-}$for the entire stand in the first year (Buchmann et al., 1995). The main sink for both $\mathrm{N}$ forms was the soil, where $87 \%$ of the ${ }^{15} \mathrm{NH}_{4}{ }^{+}$and $79 \%$ of the ${ }^{15} \mathrm{NO}_{3}{ }^{-}$were found and surprisingly eight months after labeling, $9 \%$ of the ammonium and $15 \%$ of the nitrate label were found in the understory in shrubs and the perennial grass of Picea abies, whereas Picea retained only $3 \%$ of the ${ }^{15} \mathrm{NH}_{4}{ }^{+}$and $7 \%$ of the ${ }^{15} \mathrm{NO}_{3}{ }^{-}$(Buchmann et al., 1996). Besides mineral $\mathrm{N}$ labeling of soils, dual isotope labeling $\left({ }^{15} \mathrm{~N}\right.$ and $\left.{ }^{13} \mathrm{C}\right)$ of amino acids is a widely used approach quantifying the intact uptake of amino acids by plants (Hodge, 2004; Moran-Zuloaga et al., 2015; Näsholm et al., 1998).

${ }^{15} \mathrm{NH}_{4} \mathrm{Cl}$ has also only been chosen for belowground labeling up to day and alongside $\mathrm{NO}_{3}$. Trogisch (2012) and Zeugin et al. (2010) used three chemical $\mathrm{N}$ tracers dual- 
labelled glycine, $\mathrm{K}^{15} \mathrm{NO}_{3}$ and ${ }^{15} \mathrm{NH}_{4} \mathrm{Cl}$ for ${ }^{15} \mathrm{~N}$ soil labeling under tropical broadleaf tree species to study $\mathrm{N}$ uptake patterns. Those ${ }^{15} \mathrm{~N}$ labeling experiments allow to study the preferences of species for different chemical $\mathrm{N}$ sources (Liu et al., 2016, Zeugin et al., 2010) and clearly demonstrated that multidimensional N-use complementarity can facilitate species coexistence ( $X u$ et al., 2011). However, ${ }^{15} \mathrm{~N}$ labeling experiments from belowground, if not constructed as split-root experiments, are not considering $\mathrm{N}$ sources of rhizodeposition, whereas leaf labeling might be an adequate tool for investigating differences in $\mathrm{N}$ allocation and exudation strategies (Wichern et al., 2008). However, leaflabeling with ${ }^{15} \mathrm{~N}$-urea should not be considered a pure pulse-labeling method because Gasser et al. (2015) showed quantitative evidence of overestimated rhizodeposition on red clover.

The aim of this study was to investigate whether $\mathrm{Ca}\left({ }^{15} \mathrm{NO}_{3}\right)_{2}$ or ${ }^{15} \mathrm{NH}_{4} \mathrm{Cl}$ can be used as tracers for the leaf labeling, providing an alternative to urea or ammonium nitrate to trace $\mathrm{N}$ allocation by trees. Beech and ash were chosen as model trees as their relevance in temperate broad leaf forests is high and a deviation $\mathrm{N}$ cycling induced by these trees was already observed ((Guckland et al., 2009; Langenbruch et al., 2014). We hypothesized that leaf labeling with $\mathrm{Ca}\left({ }^{15} \mathrm{NO}_{3}\right)_{2}$ and ${ }^{15} \mathrm{NH}_{4} \mathrm{Cl}$ results in 1) chemical species specific differences and 2) tree species specific differences. Furthermore, certain potential advantages over the classical labeling approaches, including a) no damage to the leaves by the tracer, b) fast ${ }^{15} \mathrm{~N}$ distribution of the $\mathrm{N}$ tracer due to high mobility of nitrate and $\mathrm{c}$ ) possibility to produce highly ${ }^{15} \mathrm{~N}$ enriched litter for further decomposition studies will be investigated and discussed. 


\subsubsection{Material and Methods}

The study is based on two experiments: 1) ${ }^{15} \mathrm{~N}$ labeling with $\mathrm{Ca}\left({ }^{15} \mathrm{NO}_{3}\right)_{2}$ and 2$){ }^{15} \mathrm{~N}$ labeling with ${ }^{15} \mathrm{NH}_{4} \mathrm{Cl}$.

\subsubsection{1 ${ }^{15} \mathrm{~N}$ labeling with $\mathrm{Ca}\left({ }^{15} \mathrm{NO}_{3}\right)_{2}$}

The experimental site $\left(10^{\circ} 05^{\prime} \mathrm{N}, 10^{\circ} 30^{\prime} \mathrm{E}, 300 \mathrm{AMSL}\right)$ was located in the southwest of Weberstedt, which belongs to the province of Thuringia (Germany) in the northeastern part of the Hainich National Park. The mean annual temperature is $7.5^{\circ} \mathrm{C}$ and the mean annual precipitation is $670 \mathrm{~mm}$. The Hainich is the largest continuous broad-leaved forest of Germany and dominated by beech and grows on a Stagnic Luvisol (WRB 2006) developed from loess that is underlaid by Triassic limestone. The in situ ${ }^{15} \mathrm{~N}$ pulse labeling of 20 beeches (Fagus sylvatica) and 20 ashes (Fraxinus excelsior) was conducted in August 2011 on trees with 3-4 m height and were compared with ten reference trees of each species. All trees including the reference trees were chosen within an area of uniform light intensity under a closed beech canopy and scattered with a maximum distance of $300 \mathrm{~m}$ from the center of the site.

\subsubsection{2 $\quad{ }^{15} \mathrm{~N}$ labeling with ${ }^{15} \mathrm{NH}_{4} \mathrm{Cl}$}

The experimental site - Göttinger Wald (513' N, 958' E, 362 AMSL) was located in the southwest of Göttingen, within the province of Lower Saxony, Germany. The Göttinger Wald is a 130 - 145 year old beech forest scattered with ashes and maple also on a Triassic limestone plateau. The mean annual temperature is $7.7^{\circ} \mathrm{C}$ and the mean annual precipitation $610 \mathrm{~mm}$ (Maraun et al., 2001). 40 ashes and 40 beeches were chosen by height of approximately $1 \mathrm{~m}$ and compared with 20 reference trees of each species. Ashes and beeches were taken from the forest with undisturbed soil and placed into pots with sufficient space for the entire rooting system (size: $23 \times 23 \mathrm{~cm}$; depth: $26 \mathrm{~cm}$ ). The trees had a reestablishing time of two months and were kept under the canopy of mature beech trees in the Göttinger Wald and transferred to an outdoor greenhouse instantly before labeling. The seedlings were irrigated regularly and herbs were removed by cutting the shoots at soil surface. The ${ }^{15} \mathrm{~N}$ pulse labeling pot experiment of 20 beeches and 20 ashes was conducted mainly in August 2012 i.e. at the same season.

\subsubsection{Labeling method}


Glass vials were used as reservoir containing the ${ }^{15} \mathrm{~N}$-labeled calcium nitrate solution (99.23 at\% ${ }^{15} \mathrm{~N}$, Campro Scientific $\mathrm{GmbH}$, Berlin, Germany) or the ${ }^{15} \mathrm{~N}$ labeled ammonium chloride solution (98 at\% ${ }^{15} \mathrm{~N}$, Campro Scientific $\mathrm{GmbH}$, Berlin, Germany). The ${ }^{15} \mathrm{~N}$ solutions were applied per gram above ground biomass with $3 * 10^{-5} \mathrm{~mol}$ in both experiments and stayed on the trees for 72 hours. The aboveground biomass is listed in Supplementary Table 2.4-1. Three leaves of each beech and three leaflets of each ash with a similar area were mechanically roughened to allow the uptake of the solution and then placed directly in the vials with the tracer solution. Three vials were fixed on the branches at different heights in each tree. The vials were closed with Parafilm and additionally covered with a transparent bag to avoid spilling on the ground. At the end of the labeling - on day three, the vials were removed with a cut behind the leaves to avoid contamination of the ground or other leaves. Leaf, stem, root and soil samples were analyzed to quantify the allocation of ${ }^{15} \mathrm{~N}$. This experiment compares data of samples taken eight days after the start of the labeling. Therefore, four beeches and four ashes for the labeling with $\mathrm{Ca}\left({ }^{15} \mathrm{NO}_{3}\right)_{2}$ and ten ashes and ten beeches for the labeling with ${ }^{15} \mathrm{NH}_{4} \mathrm{Cl}$ were compared, respectively. The other trees samples were not compared in this study because they different in sampling time.

All leaves were sampled and stems were cut $10 \mathrm{~cm}$ above the soil, in the middle of the tree and the top part. Root samples were taken $10-15 \mathrm{~cm}$ from the main root after the tree was entirely uprooted to make sure it belongs to the labeled tree and matches the soil samples. Soil sampling was also performed in up to $15 \mathrm{~cm}$ distance to the tree with a split tube in three replicates. The intact core was divided into two to three depth segments but only the top segment of $0-10 \mathrm{~cm}$ was used for comparison in this study. The soil was removed from the column, weighed, homogenized and the water content was determined in a subsample.

For the analysis of $\mathrm{N}$ content and $\delta^{15} \mathrm{~N}$ signature in plant tissue and soil, leaves, stem, root and bulk soil samples were freeze-dried, ground in a ball mill (Retsch Schwingmühle MM2, Haan, Germany) and an aliquot (approx. $2 \mathrm{mg}$ for plant tissue and $12 \mathrm{mg}$ for soil) was filled into tin capsules. Relative $\mathrm{N}$ isotope abundances in leaves, stems, roots and soil samples were measured using an elemental analyzer NA1500 (Fison-instruments, Rodano, Milano, Italy) coupled to a Delta plus isotope ratio mass spectrometer (Finnigan MAT, Bremen, Germany) through a ConFlo III interface (Thermo Electron Cooperation, Bremen, Germany). $\delta^{15} \mathrm{~N}$ values were calibrated based on co-measured certified IAEA Standards (IAEA-600, USGS26, USGS40, USGS41, IAEA-N-1, IAEA-N-2 and IAEA-NO3). 


\subsubsection{Calculation of ${ }^{15} \mathrm{~N}$ uptake}

The ${ }^{15} \mathrm{~N}$ uptake by plants from sources of different isotopic composition alters their $\delta^{15} \mathrm{~N}$ value, which follows a two-component mixing model between the ${ }^{15} \mathrm{~N}$ natural abundance isotopic signature and the signature of the incorporated tracer-derived ${ }^{15} \mathrm{~N}$ according to Gearing et al. (1991), as shown in Eq. (1):

$$
[N]_{\text {inctracer }}=[N]_{\text {compartment }} \cdot \frac{a t \%_{\text {labelled }}-a t \%_{\text {ref }}}{a t \%_{15 N-\text { Tracer }}-a t \%_{\text {ref }}}
$$

with:

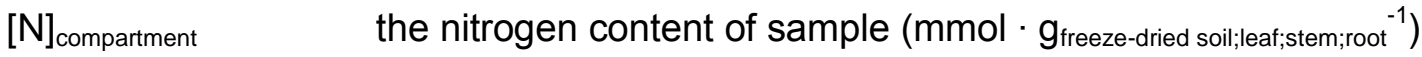

$[\mathrm{N}]_{\text {incTracer }}$ total amount of ${ }^{15} \mathrm{~N}$ incorporated into the plant in $\left(\mathrm{mmol} \cdot \mathrm{g}_{\text {freeze-dried }}\right.$ soil;leaf;:stem;root ${ }^{-1}$ )

atom $\%$ labelled ${ }^{15} \mathrm{~N}$ values of the labeled sample of the tree (leaf, stem, root, soi)

atom $\%$ ref $\quad{ }^{15} \mathrm{~N}$ values of the non-labeled reference sample of the tree (leaf, stem, root, soil)

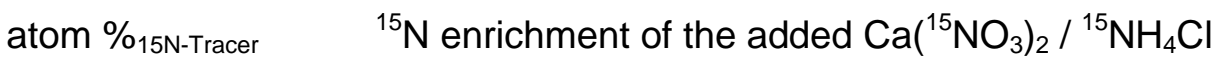

Allocation of the incorporated ${ }^{15} \mathrm{~N}$ was calculated by dividing the incorporation into a certain plant or soil compartment through the sum of total ${ }^{15} \mathrm{~N}$ recovered in all plant and soil pools. This value was displayed as $\%$ of ${ }^{15} \mathrm{~N}$ allocation by multiplying it with $100 \%$.

\subsubsection{Statistics}

Field replications were corrected for outliers using the Nalimov outlier test. All plant compartments and soil data were tested with a factorial analysis of variance (ANOVA). A Tukey HSD (honest significant difference) tests for post hoc comparison were used to compare ${ }^{15} \mathrm{~N}$ incorporation or ${ }^{15} \mathrm{~N}$ allocation as dependent variables, while tree species, ${ }^{15} \mathrm{~N}$ tracer and within-individual variation were used as independent variables (significance level of $p<0.05)$. The error bars show a standard error of the mean (SEM) in all graphs. 


\subsubsection{Results}

\subsubsection{1 $\quad{ }^{15} \mathrm{~N}$ incorporation into plant tissues and soil}

Significant differences in ${ }^{15} \mathrm{~N}$ incorporation were shown between the chosen $\mathrm{N}$ compounds and the tree species in the leaves eight days after the start of the labeling (Supplementary Table 2.4-2). The ${ }^{15} \mathrm{~N}$ values in the field study had an average of $4.8 \pm 2.3$ at $\%$ in beech and $3.5 \pm 0.4$ at\% in ash and the ${ }^{15} \mathrm{~N}$ values in the small trees reached in beech $2.0 \pm 0.1$ at\% and in ash $1.1 \pm 0.2$ at\%. Whereas $N$ form and tree species itself but also the interactions between these factors affected the ${ }^{15} \mathrm{~N}$ incorporation into leaves, only the ${ }^{15} \mathrm{~N}$ species affected the allocation to stem and soil, significantly (Supplementary Table 2.4-2).

Beech and Ash recovered between $0.812 \%$ to $5.940 \%{ }^{15} \mathrm{~N}$ from the applied ${ }^{15} \mathrm{NH}_{4} \mathrm{Cl}$ into roots, stem and soil. The pulse labeling experiment with $\mathrm{Ca}\left({ }^{15} \mathrm{NO}_{3}\right)_{2}$ resulted only in $0.001 \%$ to $0.316 \%{ }^{15} \mathrm{~N}$ from the applied tracer in roots, stem and soil (Figure 2.4-1). Beech incorporated $1.9 \%{ }^{15} \mathrm{~N}$ from the applied ${ }^{15} \mathrm{NH}_{4} \mathrm{Cl}$ in leaves and $9.6 \%{ }^{15} \mathrm{~N}$ from the applied $\mathrm{Ca}\left({ }^{15} \mathrm{NO}_{3}\right)_{2}$ (Figure 2.4-1). Ash showed the highest incorporation with $45 \%$ of the ${ }^{15} \mathrm{~N}$ applied as $\mathrm{Ca}\left({ }^{15} \mathrm{NO}_{3}\right)_{2}$ in its leaves, but only $6 \%$ of the ${ }^{15} \mathrm{~N}$ applied in the labeling with ${ }^{15} \mathrm{NH}_{4} \mathrm{Cl}$ (Figure 2.4-1).

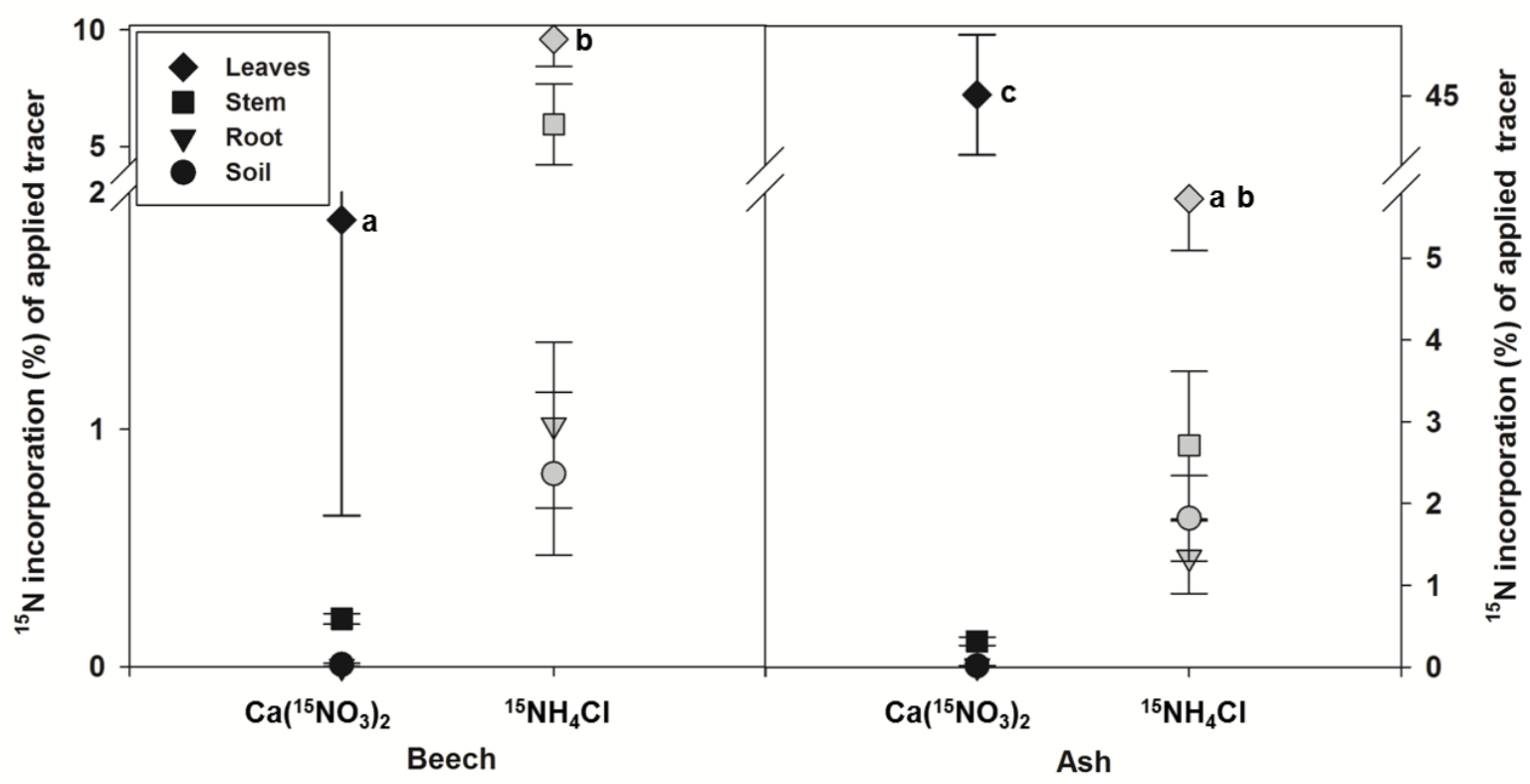

Figure 2.4-1: ${ }^{15} \mathrm{~N}$ incorporation of applied $\mathrm{Ca}\left({ }^{15} \mathrm{NO}_{3}\right)_{2}$ (black symbols; $\mathrm{N}=4$ ) and ${ }^{15} \mathrm{NH}_{4} \mathrm{Cl}$ (grey symbols; $N=10$ ) eight days after the start of the labeling for beech (left) and ash (right) in leaves (diamonds), stem (squares), roots (triangle) and soil (circles). Error bars 
show SEM. Small letters show significant $(p<0.05)$ differences of ${ }^{15} \mathrm{~N}$ in leaves between the tree species and between the ${ }^{15} \mathrm{~N}$ forms.

\subsubsection{2 $\quad{ }^{15} \mathrm{~N}$ allocation into plant tissues and soil}

Beech and ash allocated with over $90 \%$ of all fixed ${ }^{15} \mathrm{~N}$ of the $\mathrm{Ca}\left({ }^{15} \mathrm{NO}_{3}\right)_{2}$ almost everything into the leaves (Figure 2.4-2), i.e. did not allocate any relevant ${ }^{15} \mathrm{~N}$ portion belowground. Beech allocates ten times more ${ }^{15} \mathrm{~N}$ of the assimilated $\mathrm{Ca}\left({ }^{15} \mathrm{NO}_{3}\right)_{2}$ in its stem in comparison to ash, where the applied ${ }^{15} \mathrm{~N}$ was nearly exclusively recovered in the leaves. In contrast, both tree species allocated only approximately $50 \%$ of the applied ${ }^{15} \mathrm{NH}_{4} \mathrm{Cl}$ in the leaves eight days after the start of the labeling, whereas the other half was incorporated in other plant compartments and soil. $25-35 \%$ of ${ }^{15} \mathrm{~N}$ were allocated to stem and $5-15 \%$ in the root. However, ash allocated three times more ${ }^{15} \mathrm{~N}$ in its roots than beech (Figure 2.4-2). A similar pattern was found for soil, where also ash released by factor two higher amounts of the incorporated ${ }^{15} \mathrm{~N}$ compared to beech. For any labeling study based on ${ }^{15} \mathrm{~N}$ tracing of rhizodeposits, it is important to consider, that beech allocated by the factor ten and ash with $15 \%$ even by the factor 500 more ${ }^{15} \mathrm{~N}$ in the soil in the ${ }^{15} \mathrm{NH}_{4} \mathrm{Cl}$ approach in comparison to the labeling with $\mathrm{Ca}\left({ }^{15} \mathrm{NO}_{3}\right)_{2}$.

The ANOVA (Supplementary Table 2.4-3) demonstrates that this strong effect of the $\mathrm{N}$ tracer form on allocation pattern is not only highly significant in soil, but also for all other plant compartments. Comparing effects of tree species on ${ }^{15} \mathrm{~N}$ incorporation and allocations (Supplementary Table 2.4-2 and Supplementary Table 2.4-3) shows, that relative allocation in the compartments is similar between both tree species (Supplementary Table 2.4-3). 


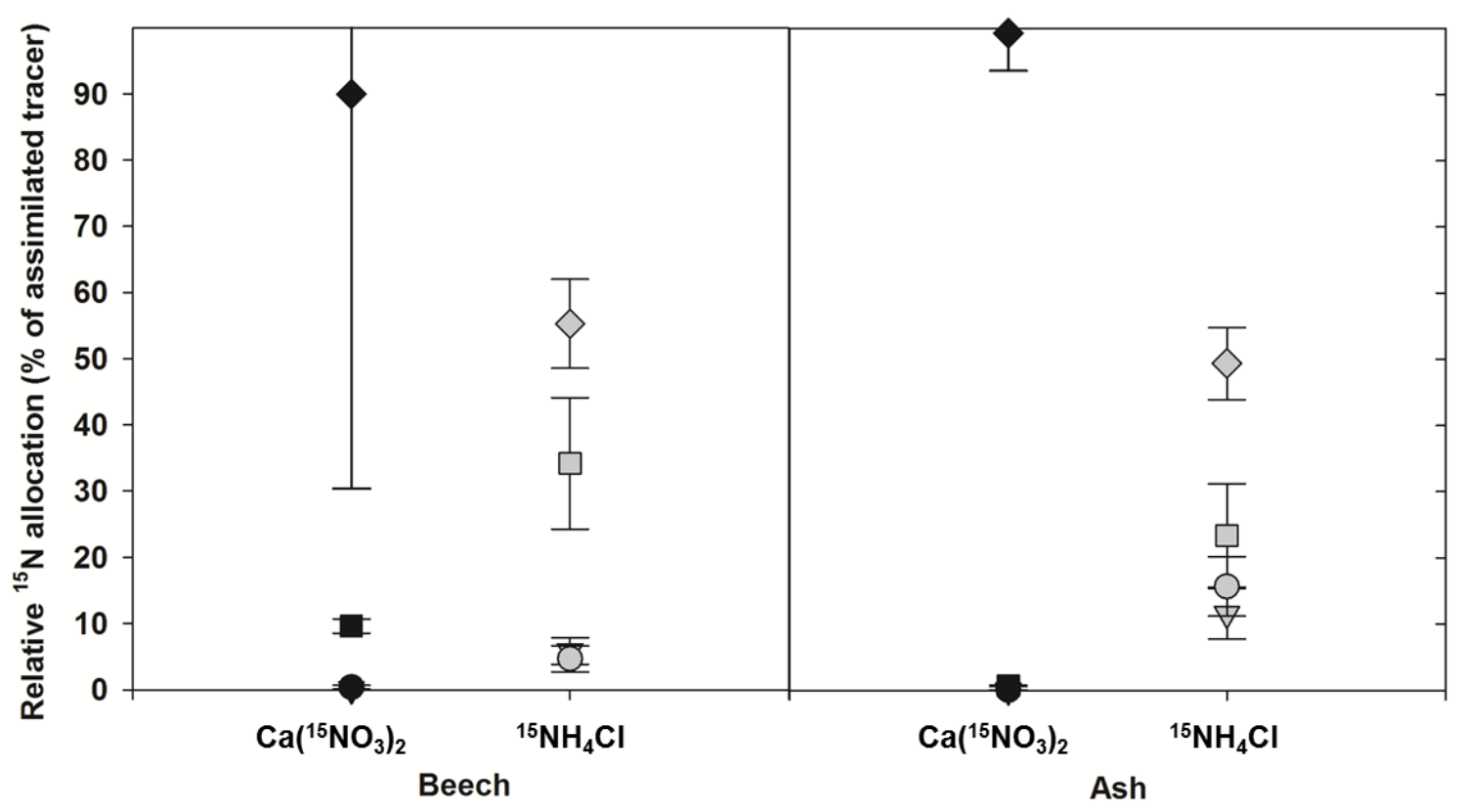

Figure 2.4-2: Relative ${ }^{15} \mathrm{~N}$ allocation of applied $\mathrm{Ca}\left({ }^{15} \mathrm{NO}_{3}\right)_{2}$ (black symbols; $\mathrm{N}=4$ ) and ${ }^{15} \mathrm{NH}_{4} \mathrm{Cl}$ (grey symbols; $\mathrm{N}=10$ ) eight days after the start of the labeling for beech (left) and ash (right) in leaves (diamonds), stem (squares), roots (triangle) and soil (circles). Error bars show SEM. 


\subsubsection{Discussion}

The ability of plants to take up nutrients directly by leaf tissues is well known (Brumme et al., 1992, Tuckey et al., 1962). Nevertheless, we used for the first time the ${ }^{15} \mathrm{~N}$ leaflabeling method based on $\mathrm{Ca}\left({ }^{15} \mathrm{NO}_{3}\right)_{2}$ on beech and ash trees in a field experiment and a ${ }^{15} \mathrm{~N}$ leaf-labeling method based on ${ }^{15} \mathrm{NH}_{4} \mathrm{Cl}$ on the same tree species in a pot experiment. Despite an identical labeling procedure and identical season for labeling, we are aware that the ecophysiological conditions for trees in field and - even if large sized - in pots are not identical and are likely to have an effect on the $\mathrm{N}$ allocation pattern presented in this study. Therefore, differences in ${ }^{15} \mathrm{~N}$ allocation cannot be solely interpreted by $\mathrm{N}$ species effect. However, the relative differences of beech and ash - observed in this study for the two $\mathrm{N}$ species suggest that there is a strong interaction between species specific allocation patterns and the ${ }^{15} \mathrm{~N}$ species and thus that $\mathrm{N}$ speciation plays a role for the ${ }^{15} \mathrm{~N}$ allocation pattern following labeling.

Previous studies preferentially used urea or $\mathrm{NH}_{4}{ }^{+}$for leaf labeling to investigate the distribution and recycling of canopy $N$ storage reserves (Ayala et al., 2014), or to produce ${ }^{15} \mathrm{~N}$ labeled plant material to trace and quantify the $\mathrm{N}$ stabilization and $\mathrm{N}$ released from litter decomposition (Bimuller et al., 2013; Schmidt and Scrimgeour, 2001). Importantly, urea foliar fertilization can cause leaf damage and negatively influence plant growth and allocation patterns. Both leaf labeling approaches did not show any damage to the unlabeled leaves. Therefore, $\mathrm{N}$ leaf-labeling with $\mathrm{Ca}\left({ }^{15} \mathrm{NO}_{3}\right)_{2}$ and ${ }^{15} \mathrm{NH}_{4} \mathrm{Cl}$ will enable longterm labeling studies on $\mathrm{N}$ rhizodeposition, $\mathrm{N}$ turnover and stabilization in soils. This is particularly important for in situ experiments in forest stands, where long-term $\mathrm{N}$ balance is one of the future challenges for forest ecosystem research.

The absolute ${ }^{15} \mathrm{~N}$ enrichments (at\%) depend on the amount of biomass, the amount of tracer and the enrichment of the ${ }^{15} \mathrm{~N}$ tracer. Thus, to compare the efficiency of the approaches, especially for not identically sized trees, we focused on the relative uptake and incorporation of ${ }^{15} \mathrm{~N}$ (in \% of applied label) by the trees in this experiment. Beech assimilates $10 \%$ and therefore five times more ${ }^{15} \mathrm{~N}$ from the applied ${ }^{15} \mathrm{NH}_{4} \mathrm{Cl}$ in its leaves in comparison to the applied $\mathrm{Ca}\left({ }^{15} \mathrm{NO}_{3}\right)_{2}$. Ash showed the highest uptake with $45 \%$ of the ${ }^{15} \mathrm{~N}$ applied with $\mathrm{Ca}\left({ }^{15} \mathrm{NO}_{3}\right)_{2}$ in its leaves which was eight times more ${ }^{15} \mathrm{~N}$ than in labeling experiment with ${ }^{15} \mathrm{NH}_{4} \mathrm{Cl}$. Glaser et al. (2012) labeled via stem injection with ammonium nitrate $\left(99.25\right.$ at $\left.\%{ }^{15} \mathrm{~N}\right)$ various broad-leaved trees and the uptake also varied between $14 \%$ in Croton macrostachys to $63 \%$ in Cupressus lusitanica in the leaves. This supports our results and demonstrates that absolute $\mathrm{N}$ uptake, also via leaf, is strongly species 
dependent. However, the final ${ }^{15} \mathrm{~N}$ enrichment achieved in the litter in the experiment of Glaser et al. (2012) and in the two leaf labeling approaches presented here are sufficient for subsequent litter turnover studies. None of the two labeling methods (leaf versus stem) could be given a clear preference if the production of ${ }^{15} \mathrm{~N}$ labelled litter is the objective for ${ }^{15} \mathrm{~N}$ tree labeling. Similarly, both $\mathrm{N}$ forms chosen for leaf labeling produced highly enriched litter and therefore, we suggest that the $\mathrm{Ca}\left({ }^{15} \mathrm{NO}_{3}\right)_{2}$ labeling method as well as the ${ }^{15} \mathrm{NH}_{4} \mathrm{Cl}$ labeling approach are suitable tools to gain highly ${ }^{15} \mathrm{~N}$ enriched litter.

Brumme et al.(1992) labeled young beeches with ${ }^{15} \mathrm{NH}_{4}{ }^{15} \mathrm{NO}_{3}$ and ${ }^{15} \mathrm{NH}_{4} \mathrm{NO}_{3}$ and stated that the $\mathrm{NH}_{4}$ uptake was $27 \%$ higher than the $\mathrm{NO}_{3}^{-}$uptake. Our results confirm this observation at least for beech, because beech showed a $12 \%$ higher $\mathrm{NH}_{4}{ }^{+}$than the $\mathrm{NO}_{3}{ }^{-}$ uptake summing up all measured compartments. However, ash in contrast incorporated four times less $\mathrm{NH}_{4}{ }^{+}$than $\mathrm{NO}_{3}{ }^{-}$into all measured compartments. Therefore, we conclude that there is likely a strong species effect on $\mathrm{N}$ allocation and consequently, for each ${ }^{15} \mathrm{~N}$ leaf labeling a careful selection of the $\mathrm{N}$ species has to be done, as the absolute amount of uptake is affected by the $\mathrm{N}$ species and the tree species. Limited knowledge on these interactions for many not yet investigated tree species requires careful consideration of this aspect for all further investigations and potential pre-experiments with the undescribed tree species.

The $\mathrm{N}$ distribution in higher plant results not only from the mineral $\mathrm{N}$ uptake by the roots and the reduction of oxidized $\mathrm{N}$ species (Gavrichkova and Kuzyakov, 2010) and but also from xylem translocation, phloem cycling and short and long term storages as amino acids or proteins (Clarkson et al., 1986; Laine et al., 1994). Rennenberg et al. (1998) discovered that the total soluble non-protein $\mathrm{N}$ content of xylem sap within beech trees is dominated by organic $\mathrm{N}$ rather than by inorganic $\mathrm{N}$ and that the assimilation of inorganic $\mathrm{N}$ in beech trees takes place mainly in the roots. Furthermore Rennenberg et al. (1998) mentioned that Arginine appears to be the main storage compound and accumulates in beech compartments in comparison to spruce, for example. Glutamine is present in beech trees in high amounts in all tissues and transport systems during the entire growing season (Rennenberg et al., 1998). The $\mathrm{N}$ storage in the stem depends highly on the season, is closely linked to tree phenology, and operates at temporal scales of months to years, with remobilization being source driven (Millard and Grelet, 2010). Although we found already a remarkable allocation of ${ }^{15} \mathrm{~N}$ from ${ }^{15} \mathrm{NH}_{4} \mathrm{Cl}$ into stem, the production of highly enriched stem, e.g. for wood decomposition studies, would presumably be even more successful in case of multiple pulse labeling at various seasons.

Glutamine was presented by Rennenberg et al. (1998) as N compound circulating between the shoot and the roots in beech but there are no comparable studies on ash. 
However, ammonium and nitrate are not incorporated similarly into universal $\mathrm{N}$ transporters such as glutamine - mainly because nitrate should be reduced before it can be used for amination of an amino acid. The reduction of $\mathrm{NO}_{3}{ }^{-}$to $\mathrm{NH}_{4}{ }^{+}$is catalyzed by nitrate and nitrite reductase enzymes and is among the most energy-intensive processes in the plants and can implicate additional respiration (Gavrichkova and Kuzyakov, 2010). Thus, it is likely, that the observed differences in the allocation of ammonium and nitratederived ${ }^{15} \mathrm{~N}$ to belowground arise from their deviating applicability to be transferred on the organic $\mathrm{N}$ transporting molecules i.e. mainly amino acids.

Beyer et al. (2013) showed in the National Park Hainich that the longevity of fine roots of ash is significantly higher than of beech, which is one of the reason explaining differences in the rhizodeposition of theses tree species. However, it is unclear whether fine roots retranslocate significant $\mathrm{N}$ amounts to other plant compartments before root death and whether re-translocation from senescent fine roots varies with $\mathrm{N}$ availability (Nadelhoffer, 2000). The strongly deviating ${ }^{15} \mathrm{~N}$ incorporation between soil and root in case of $\mathrm{Ca}\left({ }^{15} \mathrm{NO}_{3}\right)_{2}$ labeling suggests that nitrate remains in a highly mobile $\mathrm{N}$ form. This $\mathrm{N}$ form might not be lost with the fine root turnover to the soil but kept - presumably by reallocation - in the tree biomass. However, higher ${ }^{15} \mathrm{~N}$ incorporation from ${ }^{15} \mathrm{NH}_{4} \mathrm{Cl}$ into soil points towards an increased $\mathrm{N}$ loss via exudation or fine root turnover.

Glaser et al. (2012) discovered in their in situ wick labeling approach with ${ }^{15} \mathrm{NH}_{4}{ }^{+}$that only a part of the labile $\mathrm{N}$ fraction in the leaves was ${ }^{15} \mathrm{~N}$ enriched. This was similarly observed in the comparison of ${ }^{15} \mathrm{~N}$ species of the present study: Beech and ash kept over $90 \%$ of the fixed ${ }^{15} \mathrm{~N}$ from $\mathrm{Ca}\left({ }^{15} \mathrm{NO}_{3}\right)_{2}$ in their leaves but only $50 \%$ of the applied ${ }^{15} \mathrm{NH}_{4} \mathrm{Cl}$, whereas the other $50 \%$ were allocated to stem, roots and soil. We assume that the ${ }^{15} \mathrm{~N}$ from the $\mathrm{Ca}\left({ }^{15} \mathrm{NO}_{3}\right)_{2}$ tracer stays in the leaves maybe stored as Arginine or even as non-reduced nitrate. The ${ }^{15} \mathrm{~N}$ of ${ }^{15} \mathrm{NH}_{4} \mathrm{Cl}$ is much better transferred onto the classical $\mathrm{N}$ transport molecules in trees and thus ${ }^{15} \mathrm{~N}$ was much better distributed over the entire tree and allocated into soil. Therefore, we suggest to use $\mathrm{Ca}\left({ }^{15} \mathrm{NO}_{3}\right)_{2}$ only for leaf litter decomposition studies. In contrast, we recommend ${ }^{15} \mathrm{~N}$ from ammonium to trace $\mathrm{N}$ flux in stem, roots or rhizodeposits.

One great advantage of the leaf labeling approaches based on $\mathrm{Ca}\left({ }^{15} \mathrm{NO}_{3}\right)_{2}$ and ${ }^{15} \mathrm{NH}_{4} \mathrm{Cl}$ is the ability to understand and quantify the $\mathrm{N}$ cycles for adult trees in situ under less disturbed conditions than urea labeling - causing physiological damage to the leaf - or the wick method - causing mechanical damage of the stem transport systems. 


\subsubsection{Conclusions}

The two tree species investigated had a significant effect on the uptake of the $\mathrm{N}$ form $\left({ }^{15} \mathrm{Ca}\left(\mathrm{NO}_{3}\right)_{2} /{ }^{15} \mathrm{NH}_{4} \mathrm{Cl}\right)$ applied via leaf labeling into the tree. Leaf ${ }^{15} \mathrm{~N}$ labeling has advantages over the stem labeling methods because it is possible to achieve high ${ }^{15} \mathrm{~N}$ enrichments of the litter, but it has also advantages for $\mathrm{N}$ allocation studies as a specified unidirectional transport of the label is given. Compared to the urea leaf labeling method, $\mathrm{Ca}\left(\mathrm{NO}_{3}\right)_{2}$ and ${ }^{15} \mathrm{NH}_{4} \mathrm{Cl}$ do not damage the leaves, and therefore leaf labeling with $\mathrm{Ca}\left({ }^{15} \mathrm{NO}_{3}\right)_{2}$ can be used as a long-term ${ }^{15} \mathrm{~N}$ labeling technique. Both leaf labeling forms allow ${ }^{15} \mathrm{~N}$ detection even in slow-responding pools such as bulk soil organic matter after eight days. Therefore, both labeling approaches are generally appropriate for targeted studies focused on the $\mathrm{N}$ allocation pattern of individual trees within a forest ecosystem. As the biochemistry of ${ }^{15} \mathrm{NH}_{4}{ }^{+}$allocation is better understood, more ${ }^{15} \mathrm{~N}$ of the ${ }^{15} \mathrm{NH}_{4} \mathrm{Cl}$ tracer gets allocated belowground and the distribution throughout the plant organs was more homogeneous than in case ${ }^{15} \mathrm{~N}$ from $\mathrm{Ca}\left({ }^{15} \mathrm{NO}_{3}\right)_{2}$ application, the ${ }^{15} \mathrm{NH}_{4} \mathrm{Cl}$ tracer might be the more appropriate for labeling roots (e.g. for fine root turnover studies) or rhizodeposits (e.g. for rhizosphere microbial studies) in trees but further studies under $100 \%$ identical conditions, i.e. on same sized trees and same environmental conditions need to verify those results. 


\subsubsection{Acknowledgements}

We thank Sarah Zieger, Ronny Thoms, Michaela Rath (University of Göttingen) for their contribution to the experiment, the Competence Centre for Stable Isotopes (KOSI) for their continuous support with the isotope analyses, and the Hainich National Park for the work permission. Financial support for this work was provided by the German Research Foundation (DFG). This investigation contributes to project B5 of the Graduiertenkolleg 1086. 


\subsubsection{References}

Ayala, M., Bañados, P., Thielemann, M., Toro, R. (2014): Distribution and recycling of canopy nitrogen storage reserves in sweet cherry (Prunus avium) fruiting branches following ${ }^{15} \mathrm{~N}$-urea foliar applications after harvest. Ciencia E Investigacion Agraria 41, 71-80.

Benesch, M., Glaser, B., Dippold, M.,Zech, W. (2015): Soil microbial C and N turnover under Cupressus lusitanica and natural forests in southern Ethiopia assessed by decomposition of ${ }^{13} \mathrm{C}$ - and ${ }^{15} \mathrm{~N}$-labelled litter under field conditions. Plant Soil 388, 133-146.

Beyer, F., Hertel, D., Jung, K., Fender, A.-C.,Leuschner, C. (2013): Competition effects on fine root survival of Fagus sylvatica and Fraxinus excelsior. Forest Ecol Manag 302, 14-22.

Bimuller, C., Naumann, P. S., Buegger, F., Dannenmann, M., Zeller, B., von Lutzow, M., Kögel-Knabner, I. (2013): Rapid transfer of ${ }^{15} \mathrm{~N}$ from labeled beech leaf litter to functional soil organic matter fractions in a Rendzic Leptosol. Soil Biol Biochem 58, 323-331.

Brumme, R., Leimcke, U.,Matzner, E. (1992): Interception and uptake of $\mathrm{NH}_{4}{ }^{+}$and $\mathrm{NO}_{3}{ }^{-}$ from wet deposition by above-ground parts of young beech (Fagus silvatica L.) trees. Plant Soil 142, 273-279.

Buchmann, N., Gebauer, G.,Schulze, E. D. (1996): Partitioning of ${ }^{15} \mathrm{~N}$-labeled ammonium and nitrate among soil, litter, below- and above-ground biomass of trees and understory in a 15-year-old Picea abies plantation. Biogeochemistry 33, 1-23.

Buchmann, N., Schulze, E. D., Gebauer, G. (1995): ${ }^{15} \mathrm{~N}$ ammonium and ${ }^{15} \mathrm{~N}$ nitrate uptake of a 15-year-old Picea abies plantation. Oecologia 102, 361-370.

Clarkson, D. T., Hopper, M. J., Jones, L. H. P. (1986): The effect of root temperature on the uptake of nitrogen and the relative size of the root system in Lolium perenne. I. Solutions containing both $\mathrm{NH}_{4}{ }^{+}$and $\mathrm{NO}_{3}{ }^{-}$. Plant, Cell \& Environment 9, 535-545.

d'Annunzio, R., Zeller, B., Nicolas, M., Dhôte, J.-F., Saint-André, L. (2008): Decomposition of European beech (Fagus sylvatica) litter: Combining quality theory and $15 \mathrm{~N}$ labelling experiments. Soil Biology and Biochemistry 40, 322-333.

Dambrine, E., Martin, F., Carisey, N., Granier, A., Hallgren, J.-E., Bishop, K. (1995): Xylem sap composition: A tool for investigating mineral uptake and cycling in adult spruce. In L. O. Nilsson, R. F. Huttl and U. T. Johansson: Developments in Plant and Soil Sciences; Nutrient uptake and cycling in forest ecosystems, 233-241.

Garten, C. T., Hanson, P. J. (1990): Foliar retention of ${ }^{15} \mathrm{~N}$-nitrate and ${ }^{15} \mathrm{~N}$-ammonium by red maple (Acer rubrum) and white oak (Quercus alba) leaves from simulated rain. Environmental and Experimental Botany 30, 333-342.

Gasser, M., Hammelehle, A., Oberson, A., Frossard, E., Mayer, J. (2015): Quantitative evidence of overestimated rhizodeposition using ${ }^{15} \mathrm{~N}$ leaf-labelling. Soil Biology and Biochemistry 85, 10-20.

Gavrichkova, O.,Kuzyakov, Y. (2010): Respiration costs associated with nitrate reduction as estimated by ${ }^{14} \mathrm{CO}_{2}$ pulse labeling of corn at various growth stages. Plant and Soil 329, 433-445. 
Gearing, P. J., Gearing, J. N., Maughan, J. T.,Oviatt, C. A. (1991): Isotopic distribution of carbon from sewage sludge and eutrophication in the sediments and food web of Estuarine ecosystems. Environmental Science \& Technology 25, 295-301.

Glaser, B., Benesch, M., Dippold, M.,Zech, W. (2012): In situ ${ }^{15} \mathrm{~N}$ and ${ }^{13} \mathrm{C}$ labelling of indigenous and plantation tree species in a tropical mountain forest (Munessa, Ethiopia) for subsequent litter and soil organic matter turnover studies. Org Geochem 42, 1461-1469.

GonzalezPrieto, S. J., Beaupied, H., Moiroud, A.,Domenach, A. M. (1995): Uniformity of labelling of alder leaves fertilized with ${ }^{15} \mathrm{NH}_{4}{ }^{+}$and ${ }^{15} \mathrm{NO}_{3}{ }^{-}$by roots or leaves. Soil Biology and Biochemistry 27, 1559-1563.

Grassi, G., Millard, P., Gioacchini, P., Tagliavini, M. (2003): Recycling of nitrogen in the xylem of Prunus avium trees starts when spring remobilization of internal reserves declines. Tree Physiology 23, 1061-1068.

Guckland, A., Jacob, M., Flessa, H., Thomas, F. M.,Leuschner, C. (2009): Acidity, nutrient stocks, and organic-matter content in soils of a temperate deciduous forest with different abundance of European beech (Fagus sylvatica L.). Journal of Plant Nutrition and Soil Science-Zeitschrift für Pflanzenernährung und Bodenkunde 172, 500-511.

Hatton, P.-J., Kleber, M., Zeller, B., Moni, C., Plante, A. F., Townsend, K., Gelhaye, L., Lajtha, K.,Derrien, D. (2012): Transfer of litter-derived $N$ to soil mineral-organic associations: Evidence from decadal ${ }^{15} \mathrm{~N}$ tracer experiments. Organic Geochemistry 42, 1489-1501.

Heinrich, S., Dippold, M. A., Werner, C., Wiesenberg, G. L., Kuzyakov, Y.,Glaser, B. (2015): Allocation of freshly assimilated carbon into primary and secondary metabolites after in situ ${ }^{13} \mathrm{C}$ pulse labelling of Norway spruce (Picea abies). Tree Physiology 35, 1176-1191.

Hertenberger, G.,Wanek, W. (2004): Evaluation of methods to measure differential ${ }^{15} \mathrm{~N}$ labeling of soil and root N pools for studies of root exudation. Rapid Commun Mass Sp 18, 2415-2425.

Hodge, A. (2004): The plastic plant: root responses to heterogeneous supplies of nutrients. New Phytologist 162, 9-24.

Jensen, E. S. (1996): Rhizodeposition of $\mathrm{N}$ by pea and barley and its effect on soil $\mathrm{N}$ dynamics. Soil Biology and Biochemistry 28, 65-71.

Jones, D. L., Nguyen, C., Finlay, R. D. (2009): Carbon flow in the rhizosphere: carbon trading at the soil-root interface. Plant Soil 321, 5-33.

Laine, P., Bigot, J., Ourry, A.,Boucaud, J. (1994): Efects of low-temperature on nitrate uptake, and xylem and phloem flows of nitrogen, in Secale cerale L. and Brassica Napus L. New Phytologist 127, 675-683.

Langenbruch, C., Helfrich, M., Joergensen, R. G., Gordon, J.,Flessa, H. (2014): Partitioning of carbon and nitrogen during decomposition of ${ }^{13} \mathrm{C}^{15} \mathrm{~N}$-labeled beech and ash leaf litter. Journal of Plant Nutrition and Soil Science 177, 178-188.

Liu, Q., Qiao, N., Xu, X., Xin, X., Han, J. Y., Tian, Y., Ouyang, H., Kuzyakov, Y. (2016): Nitrogen acquisition by plants and microorganisms in a temperate grassland. Scientific Reports 6.

Maraun, M., Alphei, J., Beste, P., Bonkowski, M., Buryn, R., Migge, S., Peter, M., Schaefer, M.,Scheu, S. (2001): Indirect effects of carbon and nutrient amendments on the soil meso- and microfauna of a beechwood. Biology and Fertility of Soils 34, 222-229. 
Mayer, J., Buegger, F., Jensen, E. S., Schloter, M.,Hess, J. (2003): Estimating N rhizodeposition of grain legumes using a ${ }^{15} \mathrm{~N}$ in situ stem labelling method. Soil Biol Biochem 35, 21-28.

Millard, P.,Grelet, G. A. (2010): Nitrogen storage and remobilization by trees: ecophysiological relevance in a changing world. Tree Physiology 30, 1083-1095.

Moran-Zuloaga, D., Dippold, M., Glaser, B.,Kuzyakov, Y. (2015): Organic nitrogen uptake by plants: reevaluation by position-specific labeling of amino acids. Biogeochemistry 125, 359-374.

Nadelhoffer, K. J. (2000): The potential effects of nitrogen deposition on fine-root production in forest ecosystems. New Phytol 147, 131-139.

Näsholm, T., Ekblad, A., Nordin, A., Giesler, R., Hogberg, M., Hogberg, P. (1998): Boreal forest plants take up organic nitrogen. Nature 392, 914-916.

Rennenberg, H., Kreutzer, K., Papen, H.,Weber, P. (1998): Consequences of high loads of nitrogen for spruce (Picea abies) and beech (Fagus sylvatica) forests. New Phytologist 139, 71-86.

Russell, C. A., Fillery, I. R. P. (1996): In situ ${ }^{15} \mathrm{~N}$ labelling of lupin below-ground biomass. Australian Journal of Agricultural Research 47, 1035-1046.

Sawatsky, N.,Soper, R. J. (1991): A quantitative measurement of the nitrogen loss from the root system of field peas (Pisum avense L.) grown in the soil. Soil Biol Biochem 23, 255-259.

Schmidt, O.,Scrimgeour, C. M. (2001): Aa simple urea leaf-feeding method for the production of ${ }^{13} \mathrm{C}$ and ${ }^{15} \mathrm{~N}$ labelled plant material. Plant Soil 229, 197-202.

Schmidtke, K. (2005): How to calculate nitrogen rhizodeposition: a case study in estimating $\mathrm{N}$ rhizodeposition in the pea (Pisum sativum L.) and grasspea (Lathyrus sativus L.) using a continuous ${ }^{15} \mathrm{~N}$ labelling split-root technique. Soil Biology and Biochemistry 37, 1893-1897.

Sierra, J.,Daudin, D. (2010): Limited 15N transfer from stem-labeled leguminous trees to associated grass in an agroforestry system. European Journal of Agronomy 32, 240-242.

Sommer, J., Dippold, M. A., Flessa, H.,Kuzyakov, Y. (2016): Allocation and dynamics of C and $\mathrm{N}$ within plant-soil system of ash and beech. Journal of Plant Nutrition and Soil Science 179, 376-387.

Ta, T. C., Faris, M. A.,Macdowall, F. D. H. (1989): Evaluation of ${ }^{15} \mathrm{~N}$ methods to measure nitrogen transfer from alfalfa to companion timothy. Plant and Soil 114, 243-247.

Trogisch, S. (2012): The functional significance of tree diversity for soil N-pools, leaf litter decomposition and $\mathrm{N}$-uptake complementarity in subtropical forests in China. PhD Thesis, ETH Zürich, Switzerland.

Tuckey, H. B., Wittwer, S. H.,Bukovac, M. J. (1962 ): The uptake and loss of materials by leaves and other above ground parts with special reference to plant nutrition. Agrochimica, 1-28.

Wichern, F., Andreeva, D., Joergensen, R. G.,Kuzyakov, Y. (2011): Stem labeling results in different patterns of ${ }^{14} \mathrm{C}$ rhizorespiration and ${ }^{15} \mathrm{~N}$ distribution in plants compared to natural assimilation pathways. Journal of Plant Nutrition and Soil Science 174, 732-741.

Wichern, F., Eberhardt, E., Mayer, J., Joergensen, R. G.,Müller, T. (2008): Nitrogen rhizodeposition in agricultural crops: Methods, estimates and future prospects. Soil Biology and Biochemistry 40, 30-48. 
Xu, X., Ouyang, H., Richter, A., Wanek, W., Cao, G.,Kuzyakov, Y. (2011): Spatio-temporal variations determine plant-microbe competition for inorganic nitrogen in an alpine meadow. Journal of Ecology 99, 563-571.

Yasmin, K., Cadisch, G.,Baggs, E. M. (2006): Comparing ${ }^{15} \mathrm{~N}$-labelling techniques for enriching above- and below-ground components of the plant-soil system. Soil Biology and Biochemistry 38, 397-400.

Zeller, B., Colin-Belgrand, M., Dambrine, E.,Martin, F. (1998): ${ }^{15} \mathrm{~N}$ partitioning and production of ${ }^{15} \mathrm{~N}$-labelled litter in beech trees following [ $\left.{ }^{15} \mathrm{~N}\right]$ urea spray. Annals of Forest Science 55, 375-383.

Zeugin, F., Jansa, J.,Scherer-Lorenzen, M. (2010): Species-specific nitrogen uptake of three tropical tree species under intra- and interspecific competition. In E. Zürich: Zürich, 99-107. 


\subsubsection{Supplementary material}

Supplementary material for

\section{Different responses of ash and beech on nitrate versus ammonium leaf labeling}

Submitted to Journal of Plant Nutrition and Soil Science JANINE SOMMER ${ }^{1}$, MICHAELA A. DIPPOLD ${ }^{2}$, YAKOV KUZYAKOV ${ }^{1,2}$

${ }^{1}$ University of Göttingen, Soil Science of Temperate Ecosystems, Büsgenweg 2, 37077 Göttingen, Germany

${ }^{2}$ University of Göttingen, Agricultural Soil Science, Büsgenweg 2, 37077 Göttingen, Germany

Email of the corresponding author*: sommer.janine@yahoo.de 
Table 2.4-1: Mean aboveground biomass

Tree species / Leaf Biomass (g) Stem Biomass (g)

${ }^{15} \mathrm{~N}$ tracer $\quad$ Mean $+/-$ SEM $\quad$ Mean +/- SEM

\begin{tabular}{lcc}
\hline Beech $/ \mathrm{Ca}\left({ }^{15} \mathrm{NO}_{3}\right)_{2}$ & $80 \pm 6$ & $400 \pm 60$ \\
Beech $/{ }^{15} \mathrm{NH}_{4} \mathrm{Cl}$ & $8.5 \pm 0.6$ & $37 \pm 2$ \\
Ash $/ \mathrm{Ca}\left({ }^{15} \mathrm{NO}_{3}\right)_{2}$ & $55 \pm 7$ & $180 \pm 10$ \\
Ash $/{ }^{15} \mathrm{NH}_{4} \mathrm{Cl}$ & $4.3 \pm 0.4$ & $24 \pm 2$ \\
\hline
\end{tabular}

Table 2.4-2: Factorial ANOVA table of results for the ${ }^{15} \mathrm{~N}$ incorporation of the applied tracer and their variance between tree species, between ${ }^{15} \mathrm{~N}$ forms and between tree species and ${ }^{15} \mathrm{~N}$ forms effects of ${ }^{15} \mathrm{~N}$ incorporation of different plant compartments / soil.

\begin{tabular}{cccccc}
\hline Source of variation & $\begin{array}{c}\text { Sum of } \\
\text { Squares }\end{array}$ & $\begin{array}{c}\text { Degrees of } \\
\text { Freedom }\end{array}$ & $\begin{array}{c}\text { Mean } \\
\text { Square }\end{array}$ & F value & $\begin{array}{c}\text { Significance } \\
\text { level }\end{array}$
\end{tabular}
(SS)
(df)
(MS)
(F)
(p)

\section{Leaves}

Between beech and ash

$\begin{array}{lllll}1708.37 & 1 & 1708.37 & 191.04 & 0.00 \\ 1105.43 & 1 & 1105.43 & 123.61 & 0.00 \\ 2450.82 & 1 & 2450.82 & 274.06 & 0.00\end{array}$

\section{Stem}

Between beech and ash

11.88

77.56

11.88

species and ${ }^{15} \mathrm{~N}$ form

\section{Roots}

Between beech and ash

Between ${ }^{15} \mathrm{~N}$ froms

Interaction between tree

$\begin{array}{lllll}0.08 & 1 & 0.08 & 0.07 & 0.80 \\ 4.43 & 1 & 4.43 & 3.67 & 0.07 \\ 0.08 & 1 & 0.08 & 0.07 & 0.80\end{array}$


species and ${ }^{15} \mathrm{~N}$ form

Soil

Between beech and ash

1.15

0.80

0.38

Between ${ }^{15} \mathrm{~N}$ forms

7.78

7.78

5.40

0.03

Interaction between tree species and ${ }^{15} \mathrm{~N}$ form

1.15

1.15

0.80

0.38

Table 2.4-3: Factorial ANOVA results of the relative ${ }^{15} \mathrm{~N}$ allocation of the assimilated tracer between tree species, between ${ }^{15} \mathrm{~N}$ forms and between tree species and ${ }^{15} \mathrm{~N}$ form effects of relative ${ }^{15} \mathrm{~N}$ allocation to plant compartments and soil.

\begin{tabular}{llllll}
\hline Source of variation & SS & df & MS & F & p \\
\hline
\end{tabular}

Leaves

Between beech and ash

$\begin{array}{rrrrr}10.70 & 1 & 10.70 & 0.01 & 0.93 \\ 7978.04 & 1 & 7978.04 & 5.72 & 0.03 \\ 247.46 & 1 & 247.46 & 0.18 & 0.68\end{array}$

${ }^{15} \mathrm{~N}$ forms

Stem

$\begin{array}{lrrrrr}\text { Between beech and ash } & 489.98 & 1 & 489.98 & 0.81 & 0.38 \\ \text { Between }{ }^{15} \mathrm{~N} \text { forms } & 2810.87 & 1 & 2810.87 & 4.66 & 0.04 \\ \begin{array}{l}\text { Between tree species and } \\ { }^{15} \mathrm{~N} \text { forms }\end{array} & 4.42 & 1 & 4.42 & 0.01 & 0.93\end{array}$

\section{Roots}

$\begin{array}{lrrrrr}\text { Between beech and ash } & 32.39 & 1 & 32.39 & 0.48 & 0.50 \\ \text { Between }{ }^{15} \mathrm{~N} \text { forms } & 300.62 & 1 & 300.62 & 4.41 & 0.05 \\ \begin{array}{l}\text { Between tree species and } \\ { }^{15} \mathrm{~N} \text { forms }\end{array} & 32.55 & 1 & 32.55 & 0.48 & 0.50\end{array}$

Soil

\begin{tabular}{lrrrrr} 
Between beech and ash & 128.95 & 1 & 128.95 & 1.49 & 0.24 \\
Between ${ }^{15} \mathrm{~N}$ forms & 453.40 & 1 & 453.40 & 5.25 & 0.03 \\
$\begin{array}{l}\text { Between tree species and } \\
{ }^{15} \mathrm{~N} \text { forms }\end{array}$ & 147.64 & 1 & 147.64 & 1.71 & 0.21 \\
\hline
\end{tabular}




\section{Study 5}

\subsection{Beech trees fuel soil animal food webs via root derived nitrogen}

SARAH L. ZIEGER ${ }^{1 *}$, ANDREA HOLCZINGER ${ }^{1}$, JANINE SOMMER ${ }^{2}$, MICHAELA RATH $^{3}$, YAKOV KUZYAKOV ${ }^{2}$, ANDREA POLLE ${ }^{3}$, MARK MARAUN ${ }^{1}$ S STEFAN SCHEU ${ }^{1}$

Submitted to Basic and Applied Ecology

${ }^{1}$ J.F. Blumenbach Institute of Zoology and Anthropology, Animal Ecology, Georg August University Göttingen, Berliner Str. 28, 37073 Göttingen, Germany

${ }^{2}$ Büsgen Institute, Soil Science of Temperate Ecosystems, Georg August University Göttingen, Büsgenweg 2, 37077 Göttingen, Germany

${ }^{3}$ Büsgen Institute, Forest Botany and Tree Physiology, Georg August University Göttingen, Büsgenweg 2, 37077 Göttingen, Germany

"corresponding author

J.F. Blumenbach Institute of Zoology and Anthropology, Animal Ecology, Georg August University Göttingen, Berliner Str. 28, 37073 Göttingen, Germany,

phone: $+49(0) 55139-33660$, fax: $+49(0) 55139-5448$

email: szieger@gwdg.de 


\section{Abstract}

Root-derived resources are receiving increased attention as basal resources for soil animal food webs. They predominantly function as carbon $(\mathrm{C})$ and energy resources for microbial metabolism in the rhizosphere, however, root-derived nitrogen $(\mathrm{N})$ may also be important. We explored both the role of root-derived $\mathrm{C}$ and $\mathrm{N}$ for the nutrition of soil animal species. Using ${ }^{13} \mathrm{C}$ and ${ }^{15} \mathrm{~N}$ labeling we followed in situ the flux of shoot-derived $\mathrm{C}$ and $\mathrm{N}$ into the soil animal food web of young beech (Fagus sylvatica) and ash (Fraxinus excelsior) trees, dominant species in European deciduous forests. Twenty days after labeling root-derived $\mathrm{N}$ was detected in each of the studied soil animal species whereas incorporation of root-derived $C$ was only detected in the ash rhizosphere. More rootderived $\mathrm{N}$ was incorporated into soil animals from the beech as compared to the ash rhizosphere, in spite of the higher $15 \mathrm{~N}$ signatures in fine roots of ash as compared to beech. The results suggest that soil animal food webs not only rely on root $C$ but also on root $\mathrm{N}$ with the contribution of root $\mathrm{N}$ to soil animal nutrition varies with tree species. This novel pathway of plant $\mathrm{N}$ highlights the importance of root-derived resources for soil animal food webs.

Keywords: basal resources, mycorrhiza, pulse labeling, rhizodeposits, stable isotope 


\subsubsection{Introduction}

The close interrelationship between the decomposer system and plants is mediated by leaf litter input and rhizodeposition [1]. As up to $90 \%$ of net primary plant production enters the soil as detritus [2], litter has long been assumed to function as the main food source for soil animals, however recent work has shown that other resources such as those derived from roots may be more important [3-5]. A variety of substances are released actively or passively from roots into the soil as rhizodeposits [6,7]. Rhizodeposits are divided into exudates, leakages, secretions, mucilages, mucigel and lysates $[6,8]$, and include both $\mathrm{C}$ and $\mathrm{N}$ containing compounds with $\mathrm{C}$ compounds being most important. $\mathrm{N}$ containing compounds are assumed only to be of significant importance in $\mathrm{N}$ fixing plants such as legumes [9], but their role in other plants has received little attention [10]. In addition to fueling microorganisms and fostering microbial biomass in the rhizosphere, rhizodeposits affect mutualistic and antagonistic interactions between soil microorganisms and plants [11].

Soil animal communities of deciduous forests are remarkably diverse [12-14] and form complex food webs $[15,16]$. These food webs span a wide range of trophic levels including primary and secondary decomposers, and first, second and third order predators $[17,18]$. Soil animals are affected by soil properties [19], plant species [13,20] and soil microorganisms [21,22], with the latter two being mediated by rhizodeposits. Plant allocation of $\mathrm{C}$ to roots and into the rhizosphere received considerable attention in trees [23-25], but $\mathrm{N}$ allocation to roots and into the rhizosphere has been investigated for herbaceous plants in particular legumes $[9,10]$, whereas information on trees is lacking.

To investigate the flux of $\mathrm{C}$ and $\mathrm{N}$ from plants into the belowground system stable isotopes are increasingly used $[23,26]$. Adopting this approach we conducted a pulse labeling experiment in the field. By exposing trees to increased atmospheric ${ }^{13} \mathrm{CO}_{2}$ concentrations and by immersing leaves into $\mathrm{Ca}^{15} \mathrm{NO}_{3}$ solution we followed the flux of $\mathrm{C}$ and $\mathrm{N}$ into the soil animal food web. Using European beech (Fagus sylvatica) and common ash (Fraxinus excelsior) we examined if the effect of trees on the soil animal food web via rhizodeposits varies between tree species. Beech and ash were chosen as they differ in nutrient allocation patterns and mycorrhiza types. Beech roots are associated with ectomycorrhizal (EM) while ash roots with arbuscular mycorrhizal (AM) fungi. The following hypotheses were investigated: (1) incorporation of root-derived $C$ into the soil animal food web varies between tree species and is more pronounced in EM beech than 
Introduction Study 5

$\mathrm{AM}$ ash trees, and (2) root-derived $\mathrm{N}$ is of minor importance for soil animal nutrition and therefore incorporation into the soil animal food web varies little with tree species. 


\subsubsection{Material and Methods}

\subsubsection{Study site}

The experiment was conducted in a temperate deciduous beech forest in the Hainich National Park (Thüringen, Germany) near Weberstedt $\left(51^{\circ} 05^{\prime} \mathrm{N}, 10^{\circ} 28^{\prime} \mathrm{E}\right)$ at $300 \mathrm{~m}$ asl. Mean annual precipitation is $670 \mathrm{~mm}$ and mean annual air temperature $7.5^{\circ} \mathrm{C}$. With 16,000 ha the Hainich National Park is the largest continuous deciduous forest in Germany and has been declared World Heritage Nature Site in June 2011. The forest predominantly consists of beech ( $F$. sylvatica) stocking on Luvisol developed on loess underlain by Triassic Shell Limestone. The forest floor is classified as mull-like moder and the mean thickness of the litter layer is $2.8 \pm 0.1 \mathrm{~cm}[27,28]$. The topsoil $(0-10 \mathrm{~cm})$ is rather acidic with a $\mathrm{pH}_{\mathrm{KCl}}$ of $3 \cdot 3[29,30]$.

\subsubsection{Labeling}

In August 2011 eight young trees, four beech and four ash, with $2.5-4.0 \mathrm{~m}$ in height and a minimum distance from each other of $5 \mathrm{~m}$ were selected for labeling; four trees, two beech and two ash, were identified as control. The young trees grew in the understory of a closed-canopy beech forest. Around each tree used for labeling an area of $1 \times 1 \mathrm{~m}$ was trenched by inserting polyethylene panels of a thickness of $3 \mathrm{~mm}$. The panels extended $10 \mathrm{~cm}$ into the soil and $10 \mathrm{~cm}$ above the soil surface to avoid immigration of animals.

For ${ }^{15} \mathrm{~N}$ labeling $36 \mathrm{~g} \mathrm{Ca}{ }^{15} \mathrm{NO}_{3}$ (99.23 atom\% ${ }^{15} \mathrm{~N}$, Campro Scientific $\mathrm{GmbH}$, Berlin, Germany) was dissolved in $1200 \mathrm{ml}$ sterile water resulting in a $0.18 \mathrm{M}$ solution. Leaves were fed with this solution by installing three vials each with three leaves of beech or three leaflets of compound leaves of ash containing $12 \mathrm{ml} \mathrm{Ca}{ }^{15} \mathrm{NO}_{3}$ solution and incubated for $72 \mathrm{~h}$. To increase the uptake of $\mathrm{N}$, leaves were scratched prior to placement into the vials. To avoid leakage vials were covered with plastic film and enclosed into plastic bags.

For ${ }^{13} \mathrm{C}$ labeling trees were enclosed into plastic foil (thickness $0.08 \mathrm{~mm}$ ) fixed to wooden poles erected around the trees. Enclosed trees were labeled with ${ }^{13} \mathrm{CO}_{2}$ by adding $60 \mathrm{ml} 5$ $\mathrm{M} \mathrm{H}_{2} \mathrm{SO}_{4}$ to a solution containing $6.85 \mathrm{~g} \mathrm{Na}_{2}{ }^{13} \mathrm{CO}_{3}$ (99.0 atom\% ${ }^{13} \mathrm{C}$; Cambridge Isotope Laboratories, Tewksbury, USA) dissolved in $100 \mathrm{ml}$ distilled water. Air inside the enclosures was mixed using a ventilator. The labeling started at about 11 a.m. and lasted ca. $5 \mathrm{~h}$. Thereafter, the plastic foil was removed.

Twenty days after labeling the trees soil samples of a diameter of $20 \mathrm{~cm}$ to a depth of 10 $\mathrm{cm}$ were taken. Two samples spaced at least $10 \mathrm{~cm}$ were taken per tree. Soil animals 
were extracted by heat using a high-gradient canister method [31] and stored in concentrated salt water at $-7^{\circ} \mathrm{C}$.

\subsubsection{Stable isotope analysis}

Seven species of Oribatida (Chamobates sp. Hull, 1916, Damaeus gracilipes Kulczynski, 1902, Damaeus riparius Nicolet, 1855, Damaeus onustus C.L. Koch, 1844, Phthiracarus sp, Perty, 1841, Steganacarus magnus Nicolet, 1855, Xenillus tegeocranus Hermann, 1804), one Isopoda (Porcellium conspersum C.L. Koch, 1841) and two Chilopoda species (Lithobius mutabilis L. Koch, 1862, Strigamia acuminate Leach 1814) were prepared for stable isotope analysis. The species represent major taxa of detritivore soil mesofauna (Oribatida) and macrofauna (Isopoda) as well as macrofauna predators (Chilopoda). For dual $\mathrm{C}$ and $\mathrm{N}$ stable isotope ratio analysis $100-300 \mu \mathrm{g}$ of animal tissue were transferred into tin capsules and dried at $40^{\circ} \mathrm{C}$ for $24 \mathrm{~h}$. Single individuals of large Oribatida were used, but for most Oribatida species several individuals had to be pooled. In Isopoda only the head was used to prevent including food material in the gut. Samples were analyzed with a system consisting of an elemental analyzer (NA 1500, Carlo Erba, Milan, Italy) and a mass spectrometer (MAT 251, Finnigan, Bremen, Germany). The computer controlled system allows on-line measurement of stable isotopes $\left({ }^{13} \mathrm{C}\right.$ and $\left.{ }^{15} \mathrm{~N}\right)$. Their abundance $\left(\delta_{\mathrm{x}}\right)$ is expressed using the $\delta$ notation as

$$
\delta_{x}[\% 0]=\frac{R_{\text {sample }}-R_{\text {standard }}}{R_{\text {standard }}} \times 1000
$$

with $R_{\text {sample }}$ and $R_{\text {standard }}$ representing ${ }^{13} \mathrm{C} /{ }^{12} \mathrm{C}$ and ${ }^{15} \mathrm{~N} /{ }^{14} \mathrm{~N}$ ratios of samples and standard, respectively. For ${ }^{13} \mathrm{C}$ PD belemnite and for ${ }^{15} \mathrm{~N}$ atmospheric $\mathrm{N}$ served as the primary standard. Acetanilide $\left(\mathrm{C}_{8} \mathrm{H}_{9} \mathrm{NO}\right.$, Merck, Darmstadt, Germany) was used for internal calibration.

\subsubsection{Calculation of $\Delta{ }^{13} \mathrm{C}$ and $\Delta{ }^{15} \mathrm{~N}$ values}

For analyzing the enrichment in ${ }^{15} \mathrm{~N}$ and ${ }^{13} \mathrm{C}$ of soil animals and fine roots we calculated the difference in delta values between animals and fine roots from labeled and unlabeled trees as $\Delta_{\text {element }}=\delta_{\text {label }}-\delta_{\text {control }}$ with $\Delta_{\text {element }}$ the $\Delta^{13} \mathrm{C}$ and $\Delta^{15} \mathrm{~N}$ values.

Samples with mean $\Delta^{13} \mathrm{C}$ and $\Delta^{15} \mathrm{~N}$ in the range of two standard deviations of $\delta^{13} \mathrm{C}$ and $\delta^{15} \mathrm{~N}$ of control samples were assumed not to be enriched and set to zero. 


\subsubsection{Statistical analysis}

Statistical analyses were performed using R v.3.1.3 (R Core Team 2015) and the 'nlme' package [32]. Stable isotope signatures of fine roots were used as covariate, but as variations in the signatures of the animals were not significantly related to isotope signatures of roots $\left(C: F_{1,6}=0.64, P=0.455 ; N: F_{1,6}=0.34, P=0.579\right)$ of the respective tree, the covariate was removed from the final model. $\Delta^{13} \mathrm{C}$ and $\Delta^{15} \mathrm{~N}$ values of fine roots were analyzed separately using one-factorial ANOVA to test for the effect of tree species on ${ }^{13} \mathrm{C}$ and ${ }^{15} \mathrm{~N}$ enrichment in fine roots. To increase homogeneity of variances $\Delta^{15} \mathrm{~N}$ and $\Delta^{13} \mathrm{C}$ values were log-transformed.

$\Delta^{15} \mathrm{~N}$ and $\Delta^{13} \mathrm{C}$ values of soil animals were analyzed separately using linear mixed effects models including a random effect of tree identity to allow testing for the effect of tree species and $\mathrm{C}$ and $\mathrm{N}$ incorporation into soil animal species avoiding pseudo-replication of soil animal species of the same tree. $\Delta^{15} \mathrm{~N}$ and $\Delta^{13} \mathrm{C}$ values were log-transformed to improve homogeneity of variance. Means given in figures are based on back-transformed means. 


\subsubsection{Results}

Natural abundance ${ }^{15} \mathrm{~N}$ signatures in the five analyzed soil arthropod species increased in the order $P$. conspersum $(-2.40 \pm 0.35 \delta \%)<S$. magnus $(-2.19 \pm 0.51 \delta \%)<X$. tegeocranus $(-2.18 \pm 0.96 \delta \%)<D$. gracilipes $(-0.69 \pm 0.14 \delta \%)<D$. riparius $(-0.57 \pm$ $0.67 \delta \%$ ). Respective values for $\delta^{13} \mathrm{C}$ were $-25.39 \pm 0.66,-20.8 \pm 0.93,-24.26 \pm 0.89$, $25.26 \pm 0.49,-25.61 \pm 1.06 \delta \%$.

${ }^{13} \mathrm{C}$ enrichment in soil animal species $(D$. gracilipes, $D$. riparius, $P$. conspersum, $S$. magnus, $X$. tegeocranus) generally did not differ significantly $\left(F_{4,26}=1.21, P=0.33\right) . \Delta^{13} \mathrm{C}$ values of soil animals differed between tree species $\left(F_{1,6}=20.56, P=0.004\right)$; soil animals under beech generally were not enriched in ${ }^{13} \mathrm{C}$, whereas under ash they were slightly enriched but the enrichment varied strongly $(0.56 \pm 6.21 \%$; Figure $2.5-1)$ between soil animal species. $\Delta^{13} \mathrm{C}$ values of fine roots of beech and ash did not differ significantly, although they were higher in ash $(36.57 \pm 35.15 \%$ ) as compared to beech (19.36 \pm 25.43 $\left.\% ; F_{1,6}=1.32, P=0.295\right)$.

In contrast to ${ }^{13} \mathrm{C}, \Delta{ }^{15} \mathrm{~N}$ values significantly differed between soil animals $\left(\mathrm{F}_{4,26}=3.32, \mathrm{P}=\right.$ 0.025 ) and declined in the order $P$. conspersum $>X$. tegeocranus $>D$. gracilipes $>S$. magnus $>D$. riparius (Figure 2.5-2). Again, in contrast to ${ }^{13} \mathrm{C}, \Delta{ }^{15} \mathrm{~N}$ values of soil animals varied markedly between tree species $\left(F_{1,6}=13.85, P=0.010\right)$; on average soil animals under beech $(74.65 \pm 60.86 \%$ ) were more enriched than those under ash $(43.77 \pm 66.24$ $\%$ ). $\Delta^{15} \mathrm{~N}$ values of fine roots of beech and ash also significantly differed, but contrary to animal signatures; $\Delta^{15} \mathrm{~N}$ values in ash fine roots (727.56 $\pm 727.99 \%$ ) markedly exceeded those in beech fine roots $\left(62.19 \pm 40.37 \% ; F_{1,6}=9.98, P=0.020\right)$. The taxa $(L$. mutabilis, S. acuminata, Chamobates sp. D. onustus and Phthiracarus sp.) which were not replicated over the full design were also not enriched in ${ }^{13} \mathrm{C}$ but highly enriched in ${ }^{15} \mathrm{~N}$ (Table 2.5-1). 


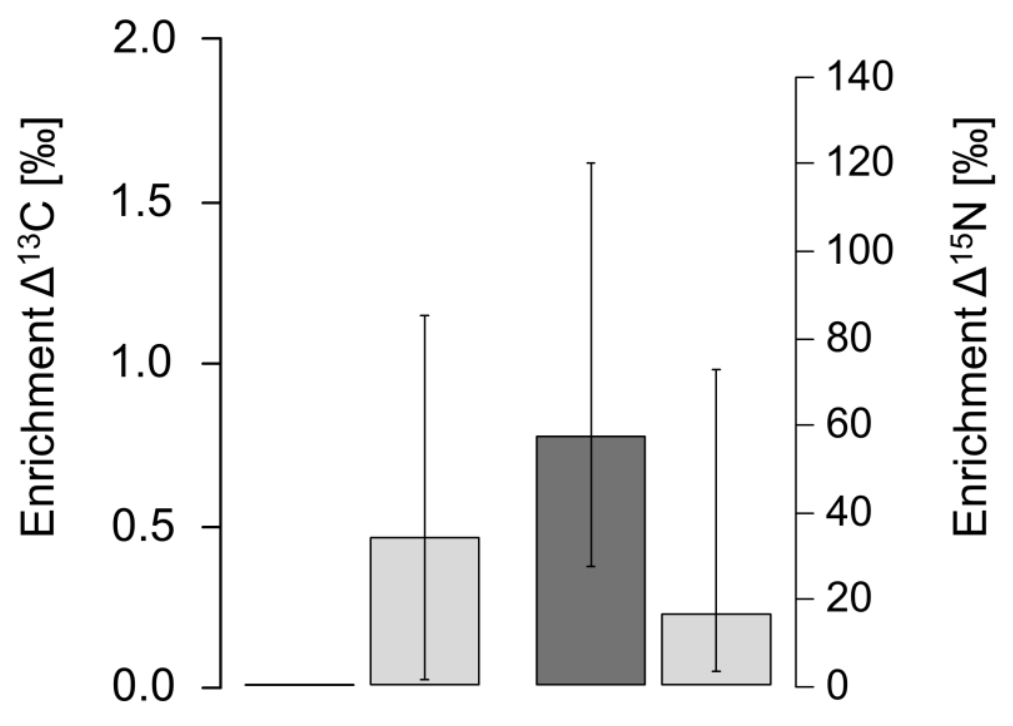

Figure 2.5-1: Enrichment in $\Delta^{13} \mathrm{C}$ and $\Delta^{15} \mathrm{~N}$ in soil animals (average of all species analyzed) under beech (dark grey) and ash (light grey) 20 days after labeling with ${ }^{13} \mathrm{CO}_{2}$ and $\mathrm{Ca}^{15} \mathrm{NO}_{3}$. Means and standard deviation are back-transformed values of logtransformed data.

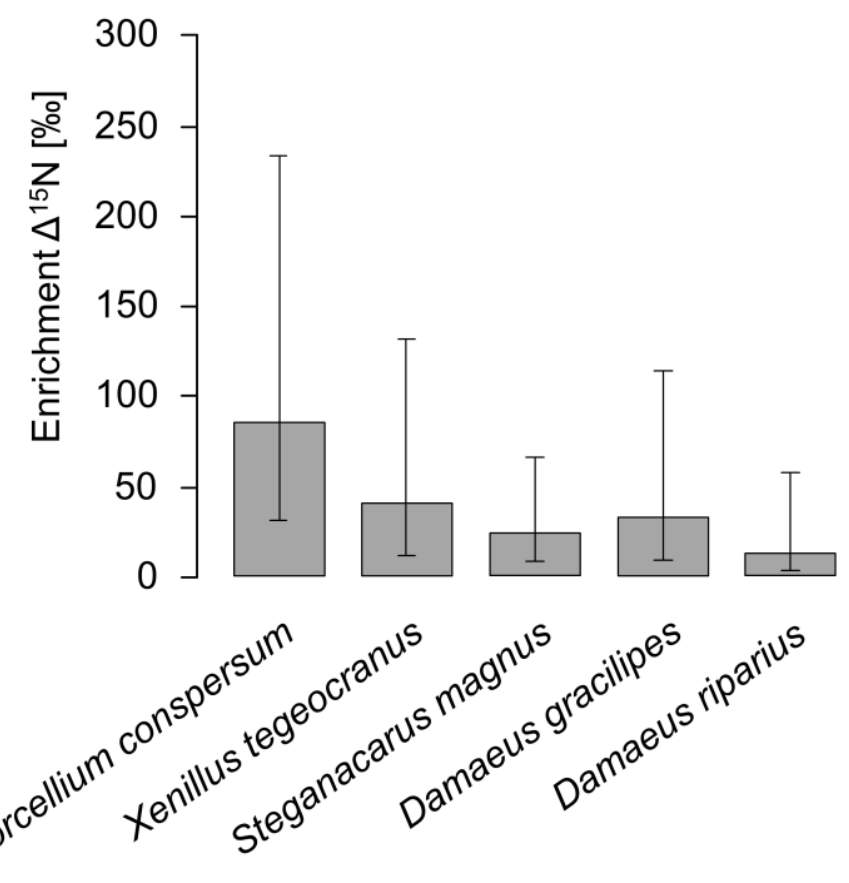

Figure 2.5-2: Enrichment in $\Delta^{15} \mathrm{~N}$ in soil animal species 20 days after labeling with ${ }^{13} \mathrm{CO}_{2}$ and $\mathrm{Ca}^{15} \mathrm{NO}_{3}$. Means and standard deviation are back-transformed values of logtransformed data. 


\subsubsection{Discussion}

\subsubsection{Incorporation of root carbon}

Contrary to our expectations soil animals incorporated little root-derived C. As it is well established that soil animals heavily rely on root-derived $C$ [3-5], the experimental set-up and the amount of ${ }^{13} \mathrm{C}$ for labeling may have been responsible for this result. Compared to most previous studies we used an in situ approach by labeling understory trees in the field. Under these conditions, a number of factors may have contributed to low uptake of ${ }^{13} \mathrm{CO}_{2}$ by the trees, most importantly shading by mature trees resulting in low photosynthetic activity. Further, the amount of label and the duration of the labeling period may not have been sufficient to allow tracing the signal in soil animals as typically only 2-4 $\%$ of the $\mathrm{C}$ fixed by plants is transferred into the soil [33]. Also, heterogeneously distributed roots, typical for field growing trees, and a mismatch between the localities where rhizodeposits were released and where soil animals were captured may have contributed to the low incorporation of root $\mathrm{C}$ into soil animals.

Incorporation of root $\mathrm{C}$ was very low but in the rhizosphere of ash exceeded that in beech where no incorporation was detectable suggesting that our first hypothesis has to be rejected. However, this conclusion presumably may be premature as incorporation of root C may have been too low to detect differences. Nevertheless, the results suggest that incorporation of root $\mathrm{C}$ in tree species differs depending on the type of mycorrhizal association. The low incorporation under beech trees is surprising as extramatrical hyphae of EM fungi associated with these trees enhance $C$ translocation into soil $[22,23,34]$ and the soil food web [35]. Also, seasonal effects might have contributed to the observed pattern as the experiment was conducted in late summer when ash trees enhance allocation of assimilates to roots ( $R$. Thoms, unpubl. results).

\subsubsection{Incorporation of root nitrogen}

In contrast to our second hypothesis soil animals were markedly enriched in ${ }^{15} \mathrm{~N}$ demonstrating that root-derived $\mathrm{N}$ forms part of the resources fueling soil animal food webs. Presumably, via rhizodeposition $\mathrm{N}$ compounds entered the rhizosphere and the surrounding soil $[6,11,36]$. Except for legumes this has been shown mainly for grasses $[10,26]$ but not for trees. Root-derived $N$ compounds are likely to be taken up quickly by microorganisms, and via microbivorous soil animals they are incorporated into the soil animal food web. However, feeding on living or dead roots or rhizosphere microorganisms may also contribute to the flux of root $\mathrm{N}$ into soil animal food webs as some detritivores 
occasionally also feed on roots [37]. In the present experiment $\mathrm{N}$ assimilated by leaves was transferred to the roots [38], which is in agreement with results of an earlier study on beech [39]. As indicated by the ${ }^{15} \mathrm{~N}$ incorporation into soil animals, part of the $\mathrm{N}$ transferred to roots was incorporated into the soil animal food web.

Notably, incorporation of root-derived $\mathrm{N}$ into soil animals varied between species and decreased in the order $P$. conspersum $>X$. tegeocranus $>D$. gracilipes $>S$. magnus $>D$. riparius. According to natural variations in stable isotope signatures in the present experiment $P$. conspersum, $X$. tegeocranus and $S$. magnus function as primary decomposers while $D$. gracilipes and $D$. riparius function as secondary decomposers which conforms to previous studies [18,40,41]. Incorporation of root-derived $N$ into these species was unlikely due to feeding on roots as ${ }^{15} \mathrm{~N}$ signatures of fine roots were not correlated with those of animals (see Material and Methods). Rather, root-derived N likely was taken up by microorganisms and thereby also transferred into leaf litter [42] and, via feeding on litter, it was incorporated into decomposer animals [43,44]. In secondary decomposers root-derived $\mathrm{N}$ likely was incorporated by feeding on microorganisms in particular fungal hyphae. Further, in certain soil mite species such as $S$. magnus rootderived $\mathrm{N}$ may have been incorporated via feeding on microbivorous or root-feeding nematodes [45]. This suggests that root-derived $\mathrm{N}$ propagates quickly into soil decomposers with nematodes likely contributing to this process.

Each of the studied soil animal species incorporated more ${ }^{15} \mathrm{~N}$ under beech as compared to ash and this contrasted the concentrations of ${ }^{15} \mathrm{~N}$ in fine roots of beech and ash. This suggests that rhizodeposition in beech including $\mathrm{N}$ compounds exceeds that in ash which conforms to recent findings $[35,46]$. Supporting this conclusion J. Sommer (unpubl. results) found the transfer of ${ }^{15} \mathrm{~N}$ into rhizosphere soil under beech to exceed that under ash trees. As shown for C, EM fungi may have contributed to higher transfer of rootderived $\mathrm{N}$ into the soil under beech as compared to ash (colonized by AM fungi) $[23,34]$. Notably and in contrast to the view that $\mathrm{N}$ is transferred only from mycorrhiza to roots, in our experiment mycorrhized root tips of beech were enriched in ${ }^{15} \mathrm{~N}$ (M. Rath, unpubl. results) indicating that $\mathrm{N}$ is also transferred from roots to mycorrhiza. This supports our conclusion that EM fungi in part fostered the transfer of $\mathrm{N}$ into the soil animal food web via fungivorous species feeding on the extramatrical mycelium of EM fungi. 


\subsubsection{Conclusions}

Incorporation of root-derived $\mathrm{C}$ into soil animals was low in this experiment, but this likely was due to low uptake of ${ }^{13} \mathrm{CO}_{2}$ by the trees and low transfer of ${ }^{13} \mathrm{C}$ into the rhizosphere. Low ${ }^{13} \mathrm{C}$ addition may have contributed to this findings. Surprisingly, root-derived $\mathrm{N}$ was incorporated into soil animals and this was more pronounced under beech associated with EM as compared to ash associated with AM. The results therefore support recent findings that the effect of EM beech on rhizosphere microorganisms exceeds that of AM ash [35]. Notably, all animal species studied incorporated root-derived $\mathrm{N}$ with the incorporation not varying significantly with animal species or trophic group, suggesting that their resources including EM fungi, saprotrophic microorganisms and nematodes, were labeled to a similar extent. 


\subsubsection{Acknowledgments}

We are grateful to the administration of Hainich National Park for permission to conduct the study in the Hainich National Park. We thank Christian Bluhm, Dieter Nünchert and Bernd Messerschmidt for help in preparing and inserting PE-panels, installing ventilators and Ronny Thoms for help in erecting wooden poles around the trees. Christian Bluhm and Benjamin Klein for help in the destructive sampling of the experiment and the Kompetenzzentrum Stabile Isotope (KOSI, University of Göttingen) for measuring stable isotopes. 


\subsubsection{References}

1. Wardle DA. Communities and Ecosystems: Linking the Aboveground and Belowground Components. Princeton, NJ.: Princeton University Press; 2002.

2. Cebrian J. Patterns in the fate of production in plant communities. The American Naturalist. 1999;154: 449-468. doi:10.1086/303244

3. Ruf A, Kuzyakov Y, Lopatovskaya O. Carbon fluxes in soil food webs of increasing complexity revealed by $14 \mathrm{C}$ labelling and $13 \mathrm{C}$ natural abundance. Soil Biology \& Biochemistry. 2006;38: 2390-2400. doi:10.1016/j.soilbio.2006.03.008

4. Pollierer MM, Langel R, Körner C, Maraun M, Scheu S. The underestimated importance of belowground carbon input for forest soil animal food webs. Ecology Letters. 2007;10: 729-736. doi:10.1111/j.1461-0248.2007.01064.x

5. Eissfeller V, Beyer F, Valtanen K, Hertel D, Maraun M, Polle A, et al. Incorporation of plant carbon and microbial nitrogen into the rhizosphere food web of beech and ash. Soil Biology \& Biochemistry. Elsevier Ltd; 2013;62: 76-81. doi:10.1016/j.soilbio.2013.03.002

6. Curl EA, Truelove B. The Rhizosphere [Internet]. Berlin/Heidelberg: SpringerVerlag; 1986. Available: http://link.springer.com/10.1007/978-3-642-70722-3

7. Jones DL, Nguyen C, Finlay RD. Carbon flow in the rhizosphere: Carbon trading at the soil-root interface. Plant and Soil. 2009;321: 5-33. doi:10.1007/s11104-009-9925-0

8. Rovira AD, Foster RC, Martin JK. Note on terminology: origin, nature and nomenclature of the organic materials in the rhizosphere. In: Harley JL, editor. The SoilRoot Interface. Elsevier; 1979. pp. 1-4. doi:10.1016/B978-0-12-325550-1.50007-0

9. Ayres E, Dromph KM, Cook R, Ostle N, Bardgett RD. The influence of belowground herbivory and defoliation of a legume on nitrogen transfer to neighbouring plants. Functional Ecology. 2007;21: 256-263. doi:10.1111/j.1365-2435.2006.01227.x

10. Wichern F, Eberhardt E, Mayer J, Joergensen RG, Müller T. Nitrogen rhizodeposition in agricultural crops: Methods, estimates and future prospects. Soil Biology \& Biochemistry. 2008;40: 30-48. doi:10.1016/j.soilbio.2007.08.010

11. Bais HP, Weir TL, Perry LG, Gilroy S, Vivanco JM. The role of root exudates in rhizosphere interactions with plants and other organisms. Annual Review of Plant Biology. 2006;57: 233-266. doi:10.1146/annurev.arplant.57.032905.105159

12. Anderson JM. The enigma of soil animal diversity. In: Vaněk J, editor. Progress in Soil Zoology Proceedings of the Fifth International Colloquium of Soil Zoology. Prague: Academia; 1975. pp. 51-58. doi:10.1007/978-94-010-1933-0

13. Scheu S. Linkages Between Tree Diversity, Soil Fauna and Ecosystem Processes. In: Scherer-Lorenzen M, Körner C, Schulze E-D, editors. Forest Diversity and Function. 167th ed. Berlin/Heidelberg: Springer-Verlag; 2005. pp. 211-233. doi:10.1007/3-54026599-6_11

14. Schaefer M. The animal community: diversity and resources. In: Rohrig E, Ulrich B, editors. Temperate Deciduous Forests (Ecosystems of the World). Amsterdam: Elsevier; 1991. pp. 51-120.

15. Digel C, Curtsdotter A, Riede J, Klarner B, Brose U. Unravelling the complex structure of forest soil food webs: Higher omnivory and more trophic levels. Oikos. 2014;123: 1157-1172. doi:10.1111/oik.00865 
16. Ehnes RB, Pollierer MM, Erdmann G, Klarner B, Eitzinger B, Digel C, et al. Lack of energetic equivalence in forest soil invertebrates. Ecology. 2014;95: 527-537. doi:10.1890/13-0620.1

17. Ponsard S, Arditi R. What can stable isotopes ( $\delta 15 \mathrm{~N}$ and $\delta 13 \mathrm{C})$ tell about the food web of soil macro-invertebrates? Ecology. 2000;81: 852-864. doi:10.1890/00129658(2000)081[0852:WCSINA]2.0.CO;2

18. Scheu S, Falca M. The soil food web of two beech forests (Fagus sylvatica) of contrasting humus type: stable isotope analysis of a macro- and a mesofauna-dominated community. Oecologia. 2000;123: 285-296. doi:10.1007/s004420051015

19. Langenbruch $\mathrm{C}$, Helfrich $\mathrm{M}$, Flessa $\mathrm{H}$. Effects of beech (Fagus sylvatica), ash (Fraxinus excelsior) and lime (Tilia spec.) on soil chemical properties in a mixed deciduous forest. Plant and Soil. 2012;352: 389-403. doi:10.1007/s11104-011-1004-7

20. Eissfeller V, Langenbruch C, Jacob A, Maraun M, Scheu S. Tree identity surpasses tree diversity in affecting the community structure of oribatid mites (Oribatida) of deciduous temperate forests. Soil Biology \& Biochemistry. Elsevier Ltd; 2013;63: 154162. doi:10.1016/j.soilbio.2013.03.024

21. Koranda M, Schnecker J, Kaiser C, Fuchslueger L, Kitzler B, Stange CF, et al. Microbial processes and community composition in the rhizosphere of European beech The influence of plant C exudates. Soil Biology \& Biochemistry. 2011;43: 551-558. doi:10.1016/j.soilbio.2010.11.022

22. Esperschütz J, Buegger F, Winkler JB, Munch JC, Schloter M, Gattinger A. Microbial response to exudates in the rhizosphere of young beech trees (Fagus sylvatica L.) after dormancy. Soil Biology \& Biochemistry. 2009;41: 1976-1985. doi:10.1016/j.soilbio.2009.07.002

23. Högberg P, Högberg MN, Göttlicher SG, Betson NR, Keel SG, Metcalfe DB, et al. High temporal resolution tracing of photosynthate carbon from the tree canopy to forest soil microorganisms. New Phytologist. 2008;177: 220-228. doi:10.1111/j.14698137.2007.02238.x

24. Kuzyakov Y, Gavrichkova O. Time lag between photosynthesis and carbon dioxide efflux from soil: a review of mechanisms and controls. Global Change Biology. 2010;16: 3386-3406. doi:10.1111/j.1365-2486.2010.02179.x

25. Subke J-A, Vallack HW, Magnusson T, Keel SG, Metcalfe DB, Högberg P, et al. Short-term dynamics of abiotic and biotic soil $13 \mathrm{CO} 2$ effluxes after in situ $13 \mathrm{CO} 2$ pulse labelling of a boreal pine forest. New Phytologist. 2009;183: 349-357. doi:10.1111/j.14698137.2009.02883.x

26. Hertenberger G, Wanek W. Evaluation of methods to measure differential $15 \mathrm{~N}$ labeling of soil and root $\mathrm{N}$ pools for studies of root exudation. Rapid communications in mass spectrometry : RCM. 2004;18: 2415-2425. doi:10.1002/rcm.1615

27. Jacob M, Viedenz K, Polle A, Thomas FM. Leaf litter decomposition in temperate deciduous forest stands with a decreasing fraction of beech (Fagus sylvatica). Oecologia. 2010;164: 1083-1094. doi:10.1007/s00442-010-1699-9

28. Langenbruch $\mathrm{C}$, Helfrich M, Joergensen RG, Gordon J, Flessa H. Partitioning of carbon and nitrogen during decomposition of ${ }^{13} \mathrm{C}{ }^{15} \mathrm{~N}$-labeled beech and ash leaf litter. Journal of Plant Nutrition and Soil Science. 2014;177: 178-188. doi:10.1002/jpln.201200643

29. Guckland A, Jacob M, Flessa H, Thomas FM, Leuschner C. Acidity, nutrient stocks, and organic-matter content in soils of a temperate deciduous forest with different abundance of European beech (Fagus sylvatica L.). Journal of Plant Nutrition and Soil Science. 2009;172: 500-511. doi:10.1002/jpln.200800072 
30. Mölder A, Bernhardt-Römermann M, Schmidt W. Forest ecosystem research in Hainich National Park (Thuringia): first results on flora and vegetation in stands with contrasting tree species diversity. Waldoekologie online. 2006;3: 83-99. Available: http://publikationen.ub.uni-frankfurt.de/frontdoor/index/index/docld/9374

31. Kempson D, Lloyd M, Ghelardi R. A new extractor for woodland litter. Pedobiologia. 1963;3: 1-21.

32. Pinheiro J, Bates D, DebRoy S, Sarkar D. nlme: Linear and Nonlinear Mixed Effects Models [Internet]. R package ver. 3.1-120. R package; 2013. Available: http://scholar.google.com/scholar?start=10\&q=mixed+effects+model\&hl=en\&as_sdt=2000 \#8

33. Jones DL, Hodge A, Kuzyakov Y. Plant and mycorrhizal regulation of rhizodeposition. New Phytologist. 2004;163: 459-480. doi:10.1111/j.14698137.2004.01130.x

34. Cairney JWG. Extramatrical mycelia of ectomycorrhizal fungi as moderators of carbon dynamics in forest soil. Soil Biology \& Biochemistry. Elsevier Ltd; 2012;47: 198208. doi:10.1016/j.soilbio.2011.12.029

35. Cesarz S, Fender A-C, Beyer F, Valtanen K, Pfeiffer B, Gansert D, et al. Roots from beech (Fagus sylvatica L.) and ash (Fraxinus excelsior L.) differentially affect soil microorganisms and carbon dynamics. Soil Biology \& Biochemistry. Elsevier Ltd; 2013;61: 23-32. doi:10.1016/j.soilbio.2013.02.003

36. Merbach W, Mirus E, Knof G, Remus R, Ruppel S, Russow R, et al. Release of carbon and nitrogen compounds by plant roots and their possible ecological importance. Journal of Plant Nutrition and Soil Science. 1999;162: 373-383. doi:10.1002/(sici)152226210.1002/(SICI)1522-2624(199908)162:4<373::AID-JPLN373>3.0.CO;2-\#

37. Endlweber K, Ruess LR, Scheu S. Collembola switch diet in presence of plant roots thereby functioning as herbivores. Soil Biology \& Biochemistry. 2009;41: 11511154. doi:10.1016/j.soilbio.2009.02.022

38. Sommer J, Dippold MA, Flessa $\mathrm{H}$, Kuzyakov Y. Allocation and dynamics of $\mathrm{C}$ and $\mathrm{N}$ within plant-soil system of ash and beech. Journal of Plant Nutrition and Soil Science. 2016;179: 376-387. doi:10.1002/jpln.201500384

39. Brumme R, Leimcke U, Matzner E. Interception and uptake of NH4 and NO3 from wet deposition by above-ground parts of young beech (Fagus silvatica L.) trees. Plant and soil. 1992;142: 273-279. doi:10.1007/BF00010972

40. Schneider K, Migge S, Norton RA, Scheu S, Langel R, Reineking A, et al. Trophic niche differentiation in soil microarthropods (Oribatida, Acari): evidence from stable isotope ratios $(15 \mathrm{~N} / 14 \mathrm{~N})$. Soil Biology \& Biochemistry. 2004;36: 1769-1774. doi:10.1016/j.soilbio.2004.04.033

41. Maraun M, Erdmann G, Fischer BM, Pollierer MM, Norton RA, Schneider K, et al. Stable isotopes revisited: Their use and limits for oribatid mite trophic ecology. Soil Biology \& Biochemistry. Elsevier Ltd; 2011;43: 877-882. doi:10.1016/j.soilbio.2011.01.003

42. Lummer D, Scheu S, Butenschoen O. Connecting litter quality, microbial community and nitrogen transfer mechanisms in decomposing litter mixtures. Oikos. 2012;121: 1649-1655. doi:10.1111/j.1600-0706.2011.20073.x

43. Rihani M, Cancela da Fonseca JP, Kiffer E. Decomposition of beech leaf litter by microflora and mesofauna. II. Food preferences and action of oribatid mites on different substrates. European Journal of Soil Biology. 1995;31: 67-79. doi:35400005491585.0020

44. David J-F, Gillon D. Annual feeding rate of the millipede Glomeris marginata on holm oak (Quercus ilex) leaf litter under Mediterranean conditions. Pedobiologia. 2002;46: 
42-52. doi:10.1078/0031-4056-00112

45. Heidemann K, Scheu S, Ruess LR, Maraun M. Molecular detection of nematode predation and scavenging in oribatid mites: Laboratory and field experiments. Soil Biology \& Biochemistry. Elsevier Ltd; 2011;43: 2229-2236. doi:10.1016/j.soilbio.2011.07.015

46. Holzwarth FM, Daenner M, Flessa H. Effects of beech and ash on small-scale variation of soil acidity and nutrient stocks in a mixed deciduous forest. Journal of Plant Nutrition and Soil Science. 2011;174: 799-808. doi:10.1002/jpln.201000369 


\title{
2.5.8 Supplementary material
}

\author{
Supplementary material for
}

\section{Beech Beech trees fuel soil animal food webs via root derived nitrogen}

\begin{abstract}
Submitted to PLOS ONE
SARAH L. ZIEGER ${ }^{1 *}$, ANDREA HOLCZINGER ${ }^{1}$, JANINE SOMMER ${ }^{2}$, MICHAELA RATH $^{3}$, YAKOV KUZYAKOV ${ }^{2}$, ANDREA POLLE ${ }^{3}$, MARK MARAUN ${ }^{1}$; STEFAN SCHEU ${ }^{1}$

1J.F. Blumenbach Institute of Zoology and Anthropology, Animal Ecology, Georg August University Göttingen, Berliner Str. 28, 37073 Göttingen, Germany

${ }^{2}$ Büsgen Institute, Soil Science of Temperate Ecosystems, Georg August University Göttingen, Büsgenweg 2, 37077 Göttingen, Germany

${ }^{3}$ Büsgen Institute, Forest Botany and Tree Physiology, Georg August University Göttingen, Büsgenweg 2, 37077 Göttingen, Germany
\end{abstract}

Email of the corresponding author*: szieger@gwdg.de 
Table 2.5-1: $\Delta^{13} C$ and $\Delta^{15} N$ values of species of Acari: Oribatida and Myriapoda: Chilopoda of beech and ash trees 20 days after labelling.

\begin{tabular}{llccccc} 
Animal species & Taxa & $\begin{array}{l}\text { Tree } \\
\text { species }\end{array}$ & Tree no. & $\begin{array}{c}\text { Replicate } \\
\text { no. }\end{array}$ & $\begin{array}{c}\boldsymbol{\Delta}^{13} \mathbf{C} \\
{[\mathbf{\delta} \%]}\end{array}$ & $\begin{array}{c}\boldsymbol{\Delta}^{\mathbf{1 5}} \mathbf{N} \\
{[\mathbf{\delta} \%]}\end{array}$ \\
\hline Phthiracarus sp. & Oribatida & Beech & 004B & 1 & 0,00 & 41,53 \\
Damaeus onustus & Oribatida & Beech & 004B & 1 & 0,00 & 26,33 \\
Damaeus onustus & Oribatida & Beech & 004B & 2 & 0,00 & 49,63 \\
Damaeus onustus & Oribatida & Beech & 004B & 3 & 0,00 & 43,00 \\
Chamobates sp. & Oribatida & Beech & 004B & 1 & 0,51 & 27,03 \\
Lithobius mutabilis & Chilopoda & Ash & 020E & 1 & 0,00 & 0,00 \\
Lithobius mutabilis & Chilopoda & Ash & 020E & 2 & 0,00 & 90,61 \\
Lithobius mutabilis & Chilopoda & Beech & 004B & 1 & 0,00 & 44,09 \\
Lithobius mutabilis & Chilopoda & Beech & 007B & 1 & 0,00 & 0,00 \\
Lithobius mutabilis & Chilopoda & Beech & 007B & 2 & 0,00 & 11,17 \\
Strigamia acuminata & Chilopoda & Ash & 020E & 1 & 0,00 & 15,69 \\
Strigamia acuminata & Chilopoda & Ash & 015E & 1 & 0,00 & 5,30 \\
Strigamia acuminata & Chilopoda & Ash & 008E & 1 & 0,00 & 4,34 \\
Strigamia acuminata & Chilopoda & Beech & 004B & 1 & 0,00 & 36,55 \\
Strigamia acuminata & Chilopoda & Beech & 004B & 2 & 0,00 & 10,81 \\
Strigamia acuminata & Chilopoda & Beech & 007B & 1 & 0,82 & 0,00 \\
Strigamia acuminata & Chilopoda & Beech & 007B & 2 & 0,00 & 0,00 \\
\hline
\end{tabular}




\section{Study 6}

\subsection{Specific $\mathrm{N}_{\min }$ uptake patterns of two widely applied poplar and willow clones for short rotation coppieses - implications for management practices}

\footnotetext{
JANINE SOMMER ${ }^{1 *}$, LINDA HARTMANN ${ }^{1}$, MICHAELA A. DIPPOLD ${ }^{2}$, YAKOV KUZYAKOV ${ }^{1,2}$, NORBERT P. LAMERSDORF

${ }^{1}$ Georg - August - University, Soil Science of Temperate Ecosystems, Büsgenweg 2, 37077 Göttingen, Germany

2 University of Göttingen, Agricultural Soil Science, Büsgenweg 2, 37077 Göttingen, Germany
}

*corresponding author

Department of Soil Science of Temperate Ecosystems, Georg-August-University Göttingen, 37077 Göttingen, Germany

Phone: + 49(0) 551-3933500Fax + 49(0)551393310

email: sommer.janine@yahoo.de

Published in Biomass and Bioenergy

February 2017, Vol 98, Pages: 236-242

DOI: 10.1016/j.biombioe.2017.02.001

The final publication is available at

http://www.sciencedirect.com/science/article/pii/S0961953417300612 


\section{Abstract}

Short rotation coppices (SRCs) are a promising alternative for environmental-friendly biomass production. However, profound understanding of nitrogen $(\mathrm{N})$ uptake and allocation dynamics and their interaction with biomass production of individual tree species is required for their sustainable management.

In-situ ${ }^{15} \mathrm{~N}$ soil pulse labeling of the widely applied willow cv. Tordis and poplar cv. Max 1 allowed tracing their uptake of $\mathrm{N}_{\min }$ and to evaluate the effect of $\mathrm{N}$ nutrition on their growth. A pulse of either ${ }^{15} \mathrm{NH}_{4} \mathrm{NO}_{3}$ or $\mathrm{NH}_{4}{ }^{15} \mathrm{NO}_{3}$ was applied to the soil of four replicate trees of each species in a pot experiment. Leaf, twigs, stem, root were analyzed to quantify the uptake and allocation of ${ }^{15} \mathrm{~N}$ after labeling.

Summarizing all compartments of poplar, almost all of ${ }^{15} \mathrm{NO}_{3}{ }^{-}(97 \%)$ from the $\mathrm{N}$ soil pool could be recovered, but only a third of the ${ }^{15} \mathrm{NH}_{4}{ }^{+}(34 \%)$. In contrast, willow incorporated exactly the same amount of ${ }^{15} \mathrm{~N}(49 \%)$ from both tracers i.e. showing no preference for a certain $\mathrm{N}_{\min }$ species. Poplar did not only have the higher $\mathrm{N}_{\min }$ uptake but also showed a higher total biomass (12.2 $\mathrm{g} \cdot$ tree $\left.^{-1}\right)$ production than willow $\left(10.2 \mathrm{~g} \cdot\right.$ tree $\left.^{-1}\right)$ in first 56 days, which goes along which its higher allocation of $\mathrm{N}$ into leaves.

We conclude that the poplar cv. Max 1 might be a better choice for biomass production, especially at arable sites with high $\mathrm{N}$ contents as well as for protecting from all negative impacts of non-closed $\mathrm{N}$ cycles as typical for classical agricultural managed sites (e.g. nitrate leaching or $\mathrm{N}_{2} \mathrm{O}$ emissions).

Key words: ${ }^{15} \mathrm{~N}$ labeling, short rotation coppices, willow, poplar, ammonium, nitrate leaching 


\subsubsection{Introduction}

Natural ecosystems such as deciduous forest are characterized by relatively closed nutrient cycles - a fact which is especially relevant for nitrogen $(N)$ if $N$ is limiting $[1,2]$. In contrast, agricultural systems frequently receive high amounts of $\mathrm{N}$ via fertilization, on which anthropogenic $\mathrm{N}$ deposition from industrial and agricultural sources adds on top and therefore frequently display a high annual loss of $\mathrm{N}$ [3]. SRCs can be regarded as an intermediate system, which are hypothesized to bring the advantages of forests nutrient dynamics at least partially into agroecosystems. However, the degree to which advantageous, which means more closed nutrient cycling can be gained by SRC is hardly investigated up to now - and surely strongly dependent on the management. Classical SRC systems consist either of successfully selected clones of poplar and willow trees or combination of both, and aim the production of high amounts of woody biomass in a short period of time. This biomass yield should be achieved with low fertilizer requirements, which will be possible in case of high $\mathrm{N}$-use efficiency and low $\mathrm{N}$ losses. Such closer $\mathrm{N}$ cycles compared to conventional annual crops imply many advantages [4]: Gaseous as well as leaching losses - e.g. the greenhouse gas $\mathrm{N}_{2} \mathrm{O}$ will be reduced as well as the groundwater contaminating nitrate leaching is likely to be reduced. However, both processes, denitrification releasing $\mathrm{N}_{2} \mathrm{O}$ and nitrate leaching, are strongly favored under high nitrate concentrations $[5,6]$ - and thus a maximal closure of the $\mathrm{N}$ cycle in SRC can be achieved by such species and clones reducing nitrate concentrations in soil solution strongest, i.e. having a strong preference for the nitrate uptake.

Poplar (Populus spp.) and willows (Salix spp.) are known for their fast growth and frost hardiness and are therefore appropriate species for intensive forestry on arable land in temperate and boreal climates [7]. However, willow yield is highly dependent on clone and site and the willow cv. Tordis ranked consistently as best clones regarding high-yielding genotypes to achieve high yield and profitability in willow (Salix spp.) SRC on different sites [8, 9]. The poplar cv. Max 1 displayed higher biomass productivity and better initial growth in comparison to other clones in Germany [10-12]. Thus, these two widely applied genotypes were chosen for a pot experiments to achieve above- and belowground physiological traits of willow versus popular. The chosen pot experiment will not only allow for growth-physiological characterization of promising clones but also enable, based on isotope labeling to assess $\mathrm{N}$ dynamics and cycles in the respective systems prior to extensive field evaluation [9, 13]. Whereas nitrate versus ammonium nutrition is intensively studied for herbaceous plants and tree species like beech, spruce, ash and oak [14-16], very little is known about the in situ $\mathrm{N}$ uptake of willow and poplar. Neither 
studies from forest nor from agroecosystems can be transferred to SRC as the tree - soil system is quite complex due to the differences to forests in leaf area index, transpiration rate, root distribution, root depth and effects on microclimate in the soil. Furthermore, especially for trees extreme species specific $\mathrm{N}$ and $\mathrm{C}$ allocation pattern have been identified $[17,18]$, suggesting that investigations of $\mathrm{N}$ uptake as well as allocation has to be performed species specific or even for each of the relevant clones used widely in SRCs. Consequently, the $\mathrm{N}$ dynamics during the initial growth period of two SRC genera poplar and willow - have been investigated in this study. $\mathrm{N}$ uptake from various sources, $\mathrm{N}$ allocation within the plant as well as the avoidance of $\mathrm{N}$ limitation during the initial growth period are key objectives of this study focusing on the link between SRC N dynamics and the tree biomass production of willow and poplar. 


\subsubsection{Material and Methods}

\subsubsection{Soil characteristics and soil sampling setup}

Pots (PVC-tubes) with a height of $30 \mathrm{~cm}$ and an inner diameter of $6.5 \mathrm{~cm}$ were filled with $4.2 \mathrm{~kg}$ soil. The soil was taken from the site of a field experiment, which was established

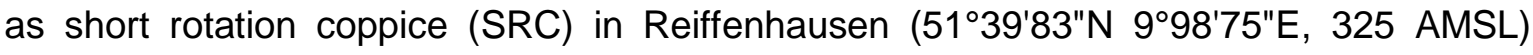
located southeast of Göttingen, Lower Saxony, Germany. An area of 1.6 hectares was established with cuttings of the commercial poplar Cv. Max 1 (Populus nigra L. $x$. maximowiczii Henry) and the willow cv. Tordis ((Salix viminalis L. $x$ Salix Schwerinii Wolf) x S. viminalis) in March 2011. The area of the field experiment, were soils was taken from, had been ploughed twice to a depth of $20 \mathrm{~cm}$ in autumn 2010 and once again in Feb. 2011 resulting in a homogenized layer of $20 \mathrm{~cm}$ depth like in the pots of the presented experiment. The climate is maritime temperate (Cfb Köppen climate classification) with a mean annual precipitation of $642 \mathrm{~mm}$ and a mean annual temperature of $9.2^{\circ} \mathrm{C}$. The soil texture is a loamy sand ( $12 \%$ clay, $23 \%$ silt, $65 \%$ fine sand) developed from loess and was classified as stagnic Cambisol [19] [20]. The soil was taken from the upper ploughed $20 \mathrm{~cm}$ between the area of willow and poplar just in front of the future SRC and identic for both tree species.

The initial mineral nitrogen $\left(\mathrm{N}_{\text {min }}\right)$ concentration was determined after $\mathrm{K}_{2} \mathrm{SO}_{4}$ extraction. 60 $\mathrm{ml} 0.5 \mathrm{M} \mathrm{K}_{2} \mathrm{SO}_{4}$ solution was added to $15 \mathrm{~g}$ field moist soil, shaken (60 min., 130 revs/minute) and filtrated. The extracts were analyzed by continuous flow injection colorimetry (Cenco/Skalar Instruments, Netherlands). The total soil nitrogen content, measured by a C-N-analyzer, (CHN-O-Rapide, VarioEL, Elementar, Hanau, Germany) was $0.6 \mathrm{mg} \mathrm{g}^{-1}( \pm 0.03)$. To determine the total cation exchange capacity a procedure described by Meiwes [21] was used and the $\mathrm{pH}$ of the soil was measured with a digital $\mathrm{pH}$-meter (inolab, WTW, Weilheim, Germany) in water and KCl.

The mean $\mathrm{pH}$ of the soil used in all treatments varied between 7.9 , measured in water and 7.2, measured in $\mathrm{KCl}$ (Table 2.6-1). The mean concentration of organic carbon $\left(\mathrm{C}_{\mathrm{org}}\right)$ was $4.5 \pm 0.3 \mathrm{mg} \mathrm{g}^{-1}$ and the carbonate content $\left(\mathrm{CaCO}_{3}\right)$ was $3.5 \pm 0.2 \%$. Total nitrogen $\left(\mathrm{N}_{\mathrm{t}}\right)$ was $0.6 \pm 0.02 \mathrm{mg} \mathrm{g}^{-1}$. The mean $\mathrm{C}_{\text {org }} / \mathrm{N}_{\mathrm{t}}$ ratio was $7.2 \pm 0.4$ (Table 2.6-1). Mean plant available $\mathrm{NO}_{3}^{-}\left(\mathrm{K}_{2} \mathrm{SO}_{4}\right.$ extraction) was $5.2 \pm 0.7 \mathrm{mg} \mathrm{kg}^{-1}$ whereas $\mathrm{NH}_{4}^{+}$concentrations were below the detection limit. The total cation exchange capacity $\left(\mathrm{CEC}_{\mathrm{t}}\right)$ was $131.5 \pm$ $1.0 \mathrm{mmol}_{\mathrm{c}} \mathrm{kg}^{-1}$. 
Table 2.6-1: Chemical soil properties at the beginning of the experiment $(N=3) \pm$ SEM.

\begin{tabular}{|c|c|c|c|c|c|c|c|c|c|}
\hline & $\begin{array}{l}\mathrm{pH} \\
\mathrm{H}_{2} \mathrm{O}\end{array}$ & $\begin{array}{l}\mathrm{pH} \\
\mathrm{KCl}\end{array}$ & $\begin{array}{l}\mathrm{C}_{\text {org }} \\
\mathrm{mg} \mathrm{g}^{-1}\end{array}$ & $\begin{array}{l}\mathrm{N}_{\mathrm{t}} \\
\mathrm{mg} \mathrm{g}^{-1}\end{array}$ & $\mathrm{C}_{\text {org }} / \mathrm{N}_{\mathrm{t}}$ & $\begin{array}{l}\mathrm{CaCO}_{3} \\
\%\end{array}$ & $\begin{array}{l}\mathrm{CEC}_{\mathrm{t}} \\
\mathrm{mmol}_{\mathrm{c}} \mathrm{kg}^{-1}\end{array}$ & $\begin{array}{l}\mathrm{NH}_{4}^{+} \\
\mathrm{mg} \mathrm{kg}^{-1}\end{array}$ & $\begin{array}{l}\mathrm{NO}_{3}^{-} \\
\mathrm{mg} \mathrm{kg}^{-1}\end{array}$ \\
\hline Mean & 7.9 & 7.2 & 4.5 & 0.6 & 7.2 & 3.5 & 131.5 & 0.0 & 5.2 \\
\hline SEM & 0.1 & 0.1 & 0.3 & 0.02 & 0.4 & 0.2 & 1.0 & 0.0 & 0.7 \\
\hline
\end{tabular}

\subsubsection{Experimental design and ${ }^{15} \mathrm{~N}$ labeling}

Each pot was prepared in the laboratory containing soil amounts resulting from the respective bulk densities quantified in the field $\left(1.2 \mathrm{~g} \mathrm{~cm}^{-3}\right)$. To obtain a uniform bulk density, each of the $5 \mathrm{~cm}$ layers was compacted separately by application of uniaxial pressure. The pots were placed in an outdoor area of the Georg - August University for 2 month for reestablishment and then 12 Poplar cv. Max 1 (Populus nigra x Populus maximowiczii) and 12 willow cv Tordis (Salix viminalis $x$ Salix schwerinii) $x$ Salix viminalis) cuttings with an average diameter of $1.2 \mathrm{~cm}( \pm 0.1 \mathrm{~cm})$ and height of $19.6 \mathrm{~cm}( \pm 0.3 \mathrm{~cm})$ were immersed into the soil. Overall 24 plants, 12 willow cuttings and 12 poplar cuttings, were grown for 49 days plus seven days after the labeling and the water content was adjusted weekly by weighing and irrigating to be greater than $50 \%$ of field capacity. At day $49{ }^{15} \mathrm{NH}_{4} \mathrm{NO}_{3}, \mathrm{NH}_{4}{ }^{15} \mathrm{NO}_{3}$ (99.23 atom\% ${ }^{15} \mathrm{~N}$, Campro Scientific $\mathrm{GmbH}$, Berlin, Germany) or non- ${ }^{15} \mathrm{~N}$-enriched $\mathrm{NH}_{4} \mathrm{NO}_{3}$ were applied as labeling or natural abundance reference solutions with $5 \mathrm{mg}$ of ammonium nitrate in two $10 \mathrm{ml}$ injections in $10 \mathrm{~cm}$ soil depth per pot using a needle syringe next to the stem. The reference treatment was performed by adding the non- ${ }^{15} \mathrm{~N}$-enriched $\mathrm{NH}_{4} \mathrm{NO}_{3}$ solution to maintain identical treatment.

Seven days after the labeling all trees were cut down and all leaves, twigs and stems were separated. Then, the soil was sampled in 3 depth $(0-10 \mathrm{~cm}, 10-20 \mathrm{~cm}$ and below 20 $\mathrm{cm}$ ) and sieved to $2 \mathrm{~mm}$. Water content was determined in a subsample of the 3 depth levels. The trees were then entirely uprooted to make sure the roots belong to the labeled trees and roots were separated into different sizes. All leaves, stems, twigs and roots were washed after removal and dried at $60^{\circ} \mathrm{C}$ to a constant mass and soil was dried at 40 ${ }^{\circ} \mathrm{C}$. All samples were weighed and grounded (plant compartments: Retsch ZM 1000, Retsch Haan Germany; soil: PM 4000, Retsch, Haan, Germany). The nutrients phosphorous, potassium, calcium and magnesium in plant compartments were analyzed by ICP-OES (Spectro Analytical Instruments, Kleve, Germany) after pressure digestion in $65 \%$ concentrated $\mathrm{HNO}_{3}$ [22]. 3 to $5 \mathrm{mg}$ of dried plant material were weighed into tin capsules and measured by elemental analyzer NA1500 (Fison-Instruments, Rodano, Milano, Italy) coupled to a Delta plus isotope ratio mass spectrometer (Finnigan MAT, 
Bremen, Germany) through a ConFlo III interface (Thermo Electron Corporation, Bremen, Germany) at the Centre for Stable Isotope Research and Analysis, Georg - August University.

\subsubsection{Calculation of ${ }^{15} \mathrm{~N}$ uptake}

The ${ }^{15} \mathrm{~N}$ uptake by plants from sources of different isotopic composition alters their $\delta^{15} \mathrm{~N}$ value, which follows a two-component mixing model between the ${ }^{15} \mathrm{~N}$ natural abundance isotopic signature and the signature of the incorporated tracer-derived ${ }^{15} \mathrm{~N}$ according to Gearing et al. [23], as shown in Eq. (1):

$$
[N]_{\text {rectracer }}=[N]_{\text {compartment }} \cdot \frac{a t \%_{\text {labelled }}-a t \%_{\text {ref }}}{a t \%_{15 N-\text { Tracer }}-a t \%_{\text {ref }}}
$$

with:

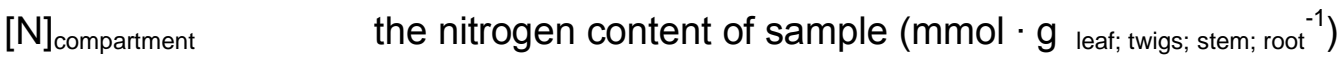

$[\mathrm{N}]_{\text {recTracer }} \quad$ recovered amount of ${ }^{15} \mathrm{~N}$ incorporated into the plant $(\mathrm{mmol} \cdot \mathrm{g}$ leaf; twigs; stem ;root $\left.{ }^{-1}\right)$

atom \%labelled ${ }^{15} \mathrm{~N}$ values of the labeled sample of the tree (leaf, twigs, stem, root)

atom $\%$ ref ${ }^{15} \mathrm{~N}$ values of the non-labeled reference sample of the tree (leaf, twigs, stem, root)

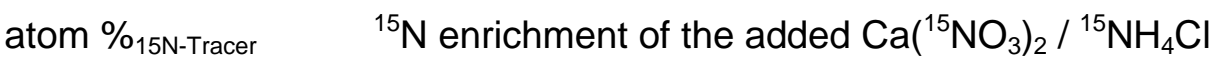

Dilution of the tracer with the respective soil-derived nitrogen source (only relevant for nitrate as ammonium was not detectable) was considered by calculating the at $\%{ }^{15} \mathrm{~N}$ Tracer value as the mixed pool of natural abundance nitrate in soil and enriched tracer added.

Allocation of the recovered ${ }^{15} \mathrm{~N}$ was calculated by dividing the recovery into a certain plant compartment through the sum of total ${ }^{15} \mathrm{~N}$ recovered in all plant pools. This value was displayed as $\%$ of ${ }^{15} \mathrm{~N}$ allocation by multiplying it with $100 \%$.

\subsubsection{Statistics}

Field replicates were tested for normal distribution using the Kolmogorov Smirnoff test, for homogeneous variances using Levene's test. As the presented dataset fulfills these assumptions it was corrected for outliers using the Nalimov outlier test with significance levels of 95\% [24]. A t-test using Statistica (version 7, Statsoft GmbH, Hamburg, Germany) with a significance level of $p<0.05$ was used to inspect the effects of tree 
species and applied $\mathrm{N}$ form on plant compartments. The error bars in graphs show standard errors of the mean (SEM) of the four replicates. 


\subsubsection{Results}

\subsubsection{Clone biomass and nutrient status}

The mean height of willow was $37.1 \pm 3.6 \mathrm{~cm}$ after 56 days of initial growth. Poplar grew in the same time $36.1 \pm 2.4 \mathrm{~cm}$. Poplar had the higher total biomass $\left(12.2 \mathrm{~g} \cdot\right.$ tree $\left.^{-1}\right) 56$ days after the cutting were placed in the soil than willow $\left(10.2 \mathrm{~g} \cdot \operatorname{tree}^{-1}\right)$ in its initial growth period (Figure 2.6-1). Dry matter yields of leaves of poplar $\left(2.3 \pm 0.1 \mathrm{~g} \cdot\right.$ tree $\left.^{-1}\right)$ were significantly higher than the leaves of willow $\left(1.2 \pm 0.1 \mathrm{~g} \cdot\right.$ tree $\left.^{-1}\right)$ (Figure 2.6-1). The foliar analyses revealed species-specific differences in the nutrient contents but for nearly each of the quantified nutrients $(\mathrm{N}, \mathrm{K}, \mathrm{Mg}, \mathrm{Ca}$ and $\mathrm{P}$ ) a sufficient-to-excellent supply compared to reference values could be found. The only exception was phosphorous $(P)$ for willow being significantly lower than required for an optimal nutrient supply [25] (Table 2.6-2).

Table 2.6-2: Mean ( \pm SEM) nutrient content of poplar leaves and willow leaves $(N=12) \pm S E M$, optimal nutrient supply according to Röhricht and Ruscher [25].

$\begin{array}{llllll}\text { Tree } & \mathrm{N} & \mathrm{K} & \mathrm{Mg} & \mathrm{Ca} & \mathrm{P}\end{array}$

mg g dry weight $)^{-1}$

$\begin{array}{llllll}\text { Willow } & 29.1(1.0) & 18.6(0.5) & 2.5(0.1) & 18.3(0.6) & 2.8(0.1) \\ \text { Optimal nutrient supply } & \mathbf{2 6 - 3 2} & \mathbf{1 6 - 1 8} & \mathbf{1 . 8 - 2 . 3} & \mathbf{1 1 - 1 4} & \mathbf{3 . 5}-\mathbf{5} \\ & & & & & \\ \text { Poplar } & 26.4(0.9) & 17.5(0.6) & 1.9(0.1) & 13.5(1.7) & 2.9(0.2) \\ \text { Optimal nutrient supply } & \mathbf{1 8 - 2 5} & \mathbf{1 2 - 1 8} & \mathbf{2 - 3} & \mathbf{3 - 1 5} & \mathbf{1 . 8 - 3}\end{array}$




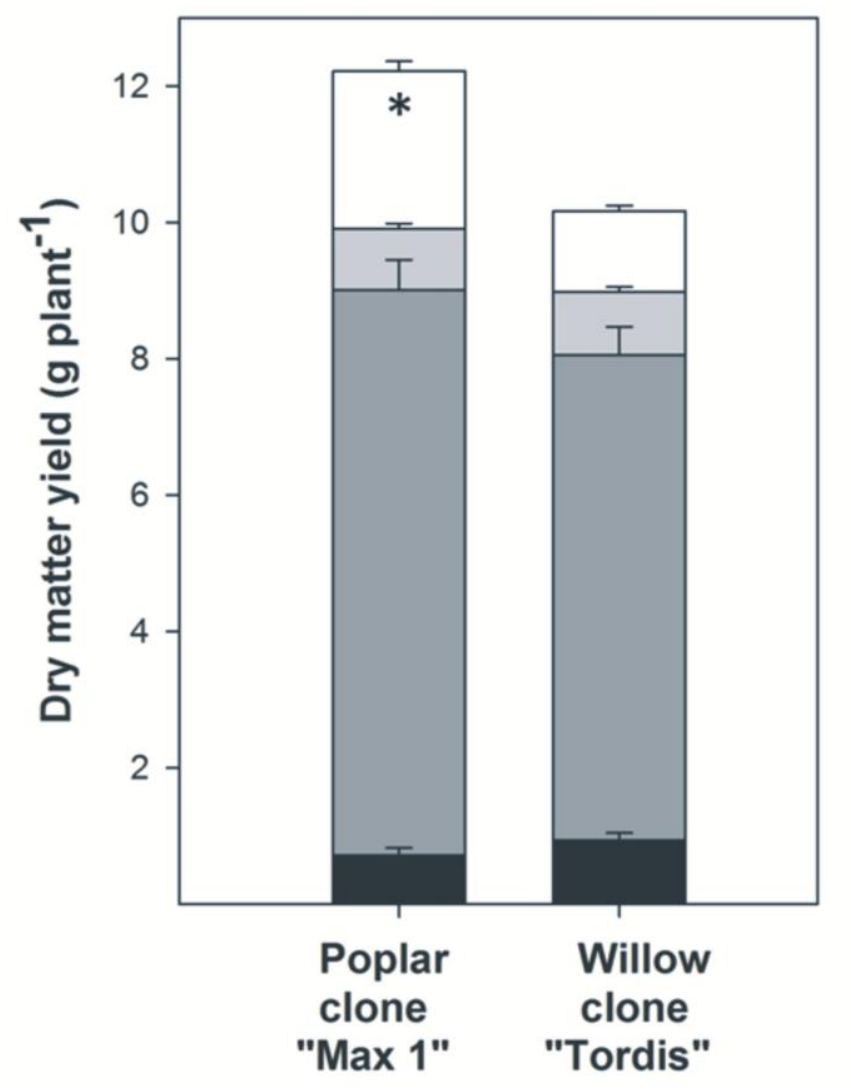

Figure 2.6-1: Dry matter yield of poplar cv. Max 1 and willow cv. Tordis after 56 days of growth ( $N=12)$; leaves (white), twigs (grey), stems (dark grey) and roots (black). Stars shows significant differences $(p<0.05)$ of dry matter content between the tree species. Error bars show SEM.

\subsubsection{2 $\quad{ }^{15} \mathrm{~N}$ recovery into plant compartments}

The overall ${ }^{15} \mathrm{~N}$ recovery from the soil-derived ${ }^{15} \mathrm{~N}_{\text {min }}$ into poplar was higher for ${ }^{15} \mathrm{NO}_{3}{ }^{-}$ (97\%) than for ${ }^{15} \mathrm{NH}_{4}{ }^{+}(34 \%)$. In contrast, recovery of both $\mathrm{N}_{\text {min }}$-species was identical for the willow cv. Tordis (49\%) (Figure 2.6-2). The highest ${ }^{15} \mathrm{~N}$ recovery from ${ }^{15} \mathrm{NO}_{3}^{-}$was found in poplar leaves $(70 \pm 1 \%)$ and was almost three times higher than ${ }^{15} \mathrm{~N}^{-\mathrm{NO}_{3}}{ }^{-}$ recovery in willow leaves (25 $\pm 1 \%$ ) (Figure 2.6-2). Irrespective of the $\mathrm{N}_{\min }$-species, leaves recovered the most ${ }^{15} \mathrm{~N}$ in both tree species followed by twigs, stem and roots (Figure 2.6-2). For twigs and stem, the ${ }^{15} \mathrm{~N}$ recovery from the ${ }^{15} \mathrm{NH}_{4}{ }^{+}$was only half in poplar than in willow.

Comparing the two $\mathrm{N}_{\min }$-species reveals that poplar recovered more than twice of the ${ }^{15} \mathrm{NO}_{3}{ }^{-}$than of the ${ }^{15} \mathrm{NH}_{4}{ }^{+}$in leaves, twigs and stem (Figure 2.6-2, Supplementary Table 2.6-3). Willow recovered also twice of the ${ }^{15} \mathrm{NO}_{3}{ }^{-}$than of the ${ }^{15} \mathrm{NH}_{4}{ }^{+}$in its roots but less of the ${ }^{15} \mathrm{NO}_{3}{ }^{-}$than of the ${ }^{15} \mathrm{NH}_{4}{ }^{+}$in the stem, slightly more in the twigs and identical amounts 
in the leaves (Figure 2.6-2, Supplementary Table 2.6-3). In summary, total uptake of soil nitrate was twice as high in poplar (97\%) than in willow (49\%).

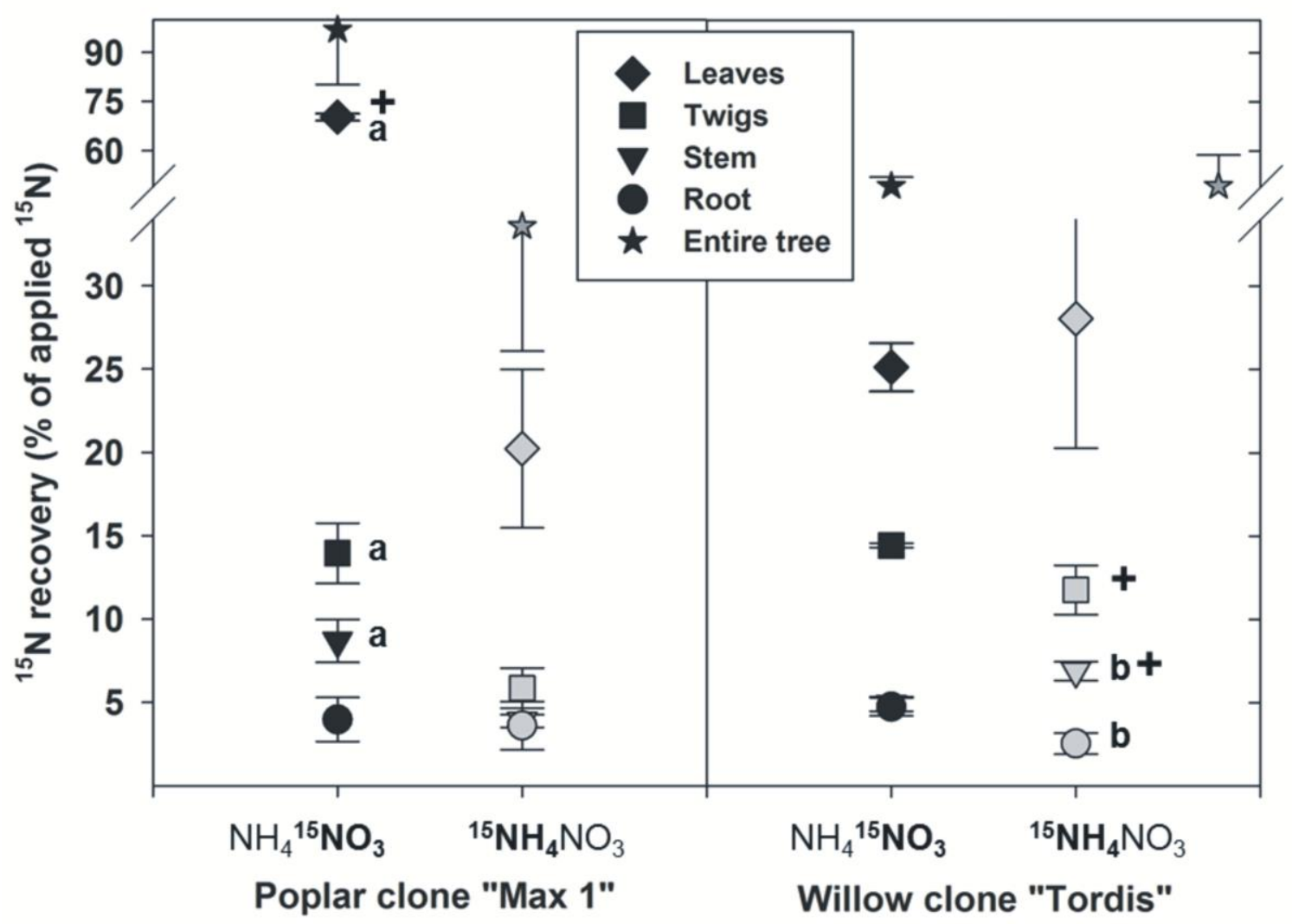

Figure 2.6-2: ${ }^{15} \mathrm{~N}$ recovery in \% of applied $\mathrm{NH}_{4}{ }^{15} \mathrm{NO}_{3}$ (black symbols; $\mathrm{N}=4$ ) and ${ }^{15} \mathrm{NH}_{4} \mathrm{NO}_{3}$ (grey symbols; $N=4$ ) seven days after the start of the labeling for poplar (left) and willow (right) in leaves (diamonds), twigs (squares), stem (triangle), roots (circles) and the all measured compartments of the tree (star). Error bars show SEM. Plus (+) shows significant differences $(p<0.05)$ of ${ }^{15} \mathrm{~N}$ in that plant compartment between the tree species. Lower case letters show significant differences $(p<0.05)$ of ${ }^{15} \mathrm{~N}$ in that plant compartment between the $N_{\min }$-species in poplar (a) and willow (b).

\subsubsection{3 $\quad{ }^{15} \mathrm{~N}$ allocation into tree compartments}

Poplar cv. Max 1 and willow cv. Tordis had the same allocation patterns seven days after the start of the labeling. The vast majority of the ${ }^{15} \mathrm{~N}$ from both tracer forms was allocated into the leaves, followed by the twigs, stem and roots (Figure 2.6-3).

Poplar cv Max 1 allocated $73 \%$ of the assimilated ${ }^{15} \mathrm{NO}_{3}{ }^{-}$in the leaves which is $30 \%$ more ${ }^{15} \mathrm{NO}_{3}{ }^{-}$in comparison to willow cv. Tordis $(51 \%)$, which allocates instead twice as much of 
the ${ }^{15} \mathrm{NO}_{3}{ }^{-}$in roots $(10 \%)$ and twigs (30\%) as poplar (Supplementary Table 2.6-4). The allocation of the ${ }^{15} \mathrm{NH}_{4}{ }^{+}$had also its maximum in the leaves but with similar allocation of $60 \%$ in poplar and in willow.

Comparing the two $\mathrm{N}_{\min }$-species reveals no significantly different allocation pattern for poplar (Supplementary Table 2.6-4). However, willow allocates twice as much ${ }^{15} \mathrm{NO}_{3}{ }^{-}$in its roots in comparison to ${ }^{15} \mathrm{NH}_{4}^{+}$and twice as much ${ }^{15} \mathrm{NH}_{4}{ }^{+}$in its stem compared to ${ }^{15} \mathrm{NO}_{3}{ }^{-}$ (Figure 2.6-3, Supplementary Table 2.6-4).

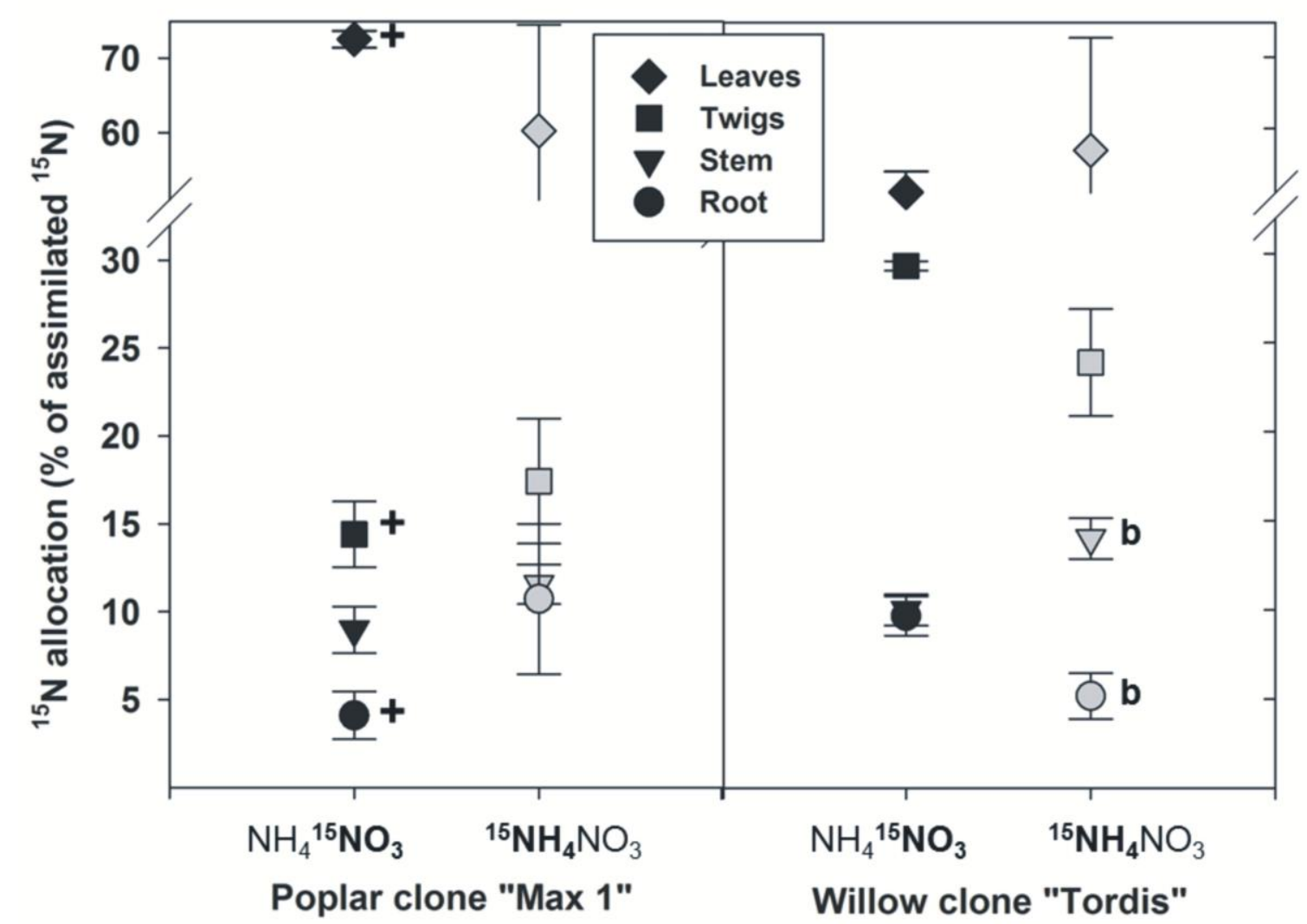

Figure 2.6-3: ${ }^{15} \mathrm{~N}$ allocation in \% of assimilated ${ }^{15} \mathrm{NO}_{3}$ (black symbols; $\mathrm{N}=4$ ) and ${ }^{15} \mathrm{NH}_{4} \mathrm{NO}_{3}$ (grey symbols; $\mathrm{N}=4$ ) seven days after the start of the labeling for poplar (left) and willow (right) in leaves (diamonds), twigs (squares), stem (triangle), roots (circles). Error bars show SEM. Plus (+) shows significant differences $(p<0.05)$ of ${ }^{15} \mathrm{~N}$ in that plant compartment between the tree species. Lower case letters show significant differences ( $p$ $<0.05$ ) of ${ }^{15} \mathrm{~N}$ in that plant compartment between the $N_{\text {min }}$-species in poplar (a) and willow (b). 


\subsubsection{4 $\quad{ }^{15} \mathrm{~N}$ incorporation of $\mathrm{N}$ pools}

Poplar and willow had different incorporation patterns seven days after the start of the labeling. Willow incorporated the most ${ }^{15} \mathrm{~N}$ from ${ }^{15} \mathrm{NO}_{3}{ }^{-}$per stem $\mathrm{N}(14.6 \pm 1.3 \%)$ and per twigs $\mathrm{N}(10.8 \pm 0.4 \%)$ whereas stem and leaves were the most important $\mathrm{N}$ pools in poplar where ${ }^{15} \mathrm{~N}$ was incorporated $(6.9 \pm 0.5 \%$ and $6.2 \pm 0.9 \%$, respectively). The willow incorporation of nitrate ${ }^{15} \mathrm{~N}$ was twice as much as poplar for stem twigs and root and only for leaves poplar incorporated more nitrate-derived ${ }^{15} \mathrm{~N}$ than poplar did (Supplementary Table 2.6-5).

Incorporation of $\mathrm{NH}_{4}{ }^{+}$-derived $\mathrm{N}$ into the twig and stem $\mathrm{N}$ pool of willow exceeded the one in poplar for more than twice (Figure 2.6-4, Supplementary Table $2.6-5$ ). ${ }^{15} \mathrm{~N}$ incorporation of the pool differed in all plant compartments between the $\mathrm{N}_{\min }$-species in poplar and willow, except the roots in willow (Supplementary Table 2.6-5 ).

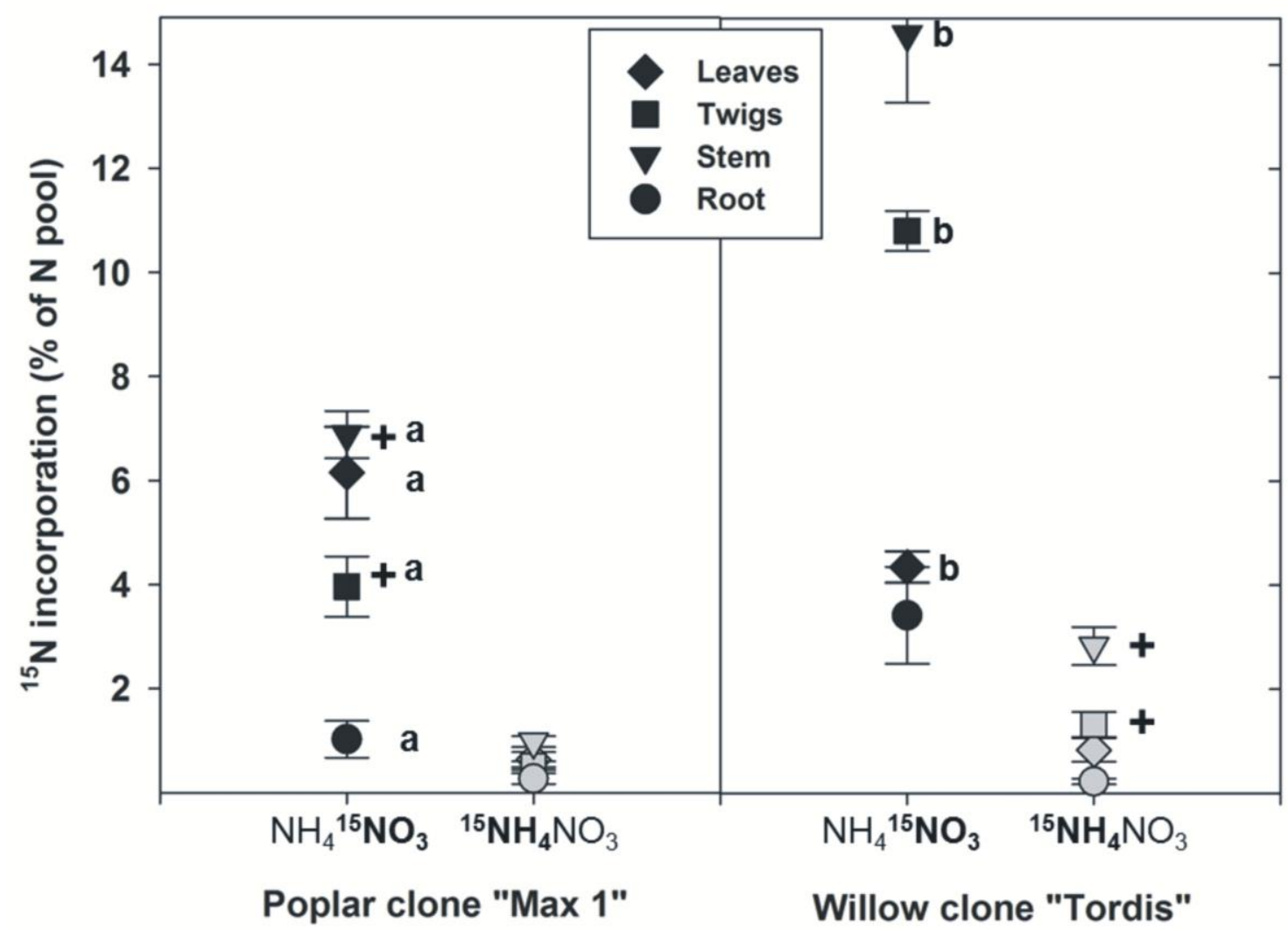

Figure 2.6-4: ${ }^{15} \mathrm{~N}$ incorporation in \% of $\mathrm{N}$ pool, ${ }^{15} \mathrm{NO}_{3}$ (black symbols; $\mathrm{N}=4$ ) and ${ }^{15} \mathrm{NH}_{4} \mathrm{NO}_{3}$ (grey symbols; $N=4$ ) seven days after the start of the labeling for poplar (left) and willow (right) in leaves (diamonds), twigs (squares), stem (triangle), roots (circles). Error bars show SEM. Plus $(+)$ shows significant differences $(p<0.05)$ of ${ }^{15} \mathrm{~N}$ in that plant 
compartment between the tree species. Lower case letters show significant differences ( $p$ $<0.05$ ) of ${ }^{15} \mathrm{~N}$ in that plant compartment between the $\mathrm{N}_{\text {min }}$-species in poplar (a) and willow (b). 


\subsubsection{Discussion}

\subsubsection{Species-specific uptake of ammonium and nitrate}

Poplar clones and willow clones are well adapted to slightly acidic to neutral soils [25-27] despite nutrient speciation can be different under deviating conditions. Our results show that poplar cv. Max 1 and willow cv. Tordis have the ability to meet their $\mathrm{N}$ demand from both $\mathrm{N}_{\text {min }}$-species of the soil solution, $\mathrm{NH}_{4}{ }^{+}$as well as $\mathrm{NO}_{3}{ }^{-}$. This observation may partly explain the distribution of the genera over a wide geographical and ecological range [28, 29]

High $\mathrm{pH}$, ambient temperature and good oxygen supply support nitrifying microorganisms in soils, resulting in high rates of net nitrification [30-34]. In our study, neutral soil reaction $(\mathrm{pH}>7)$ and intensively ploughed A horizon led to nitrification rates much higher than the ammonification rates resulting in ammonia concentrations below the detection limit. Under such conditions in the field it was shown that nitrate leaching is higher under willow than under poplar [35]. This might be explained by the results of this pot experiment demonstrating that willow takes up less nitrate than ammonium which may account for higher nitrate soil solution concentrations and higher leaching under willow [35, 36].

Summing up over the entire poplar plant almost all of ${ }^{15} \mathrm{NO}_{3}{ }^{-}(97 \%)$ from the $\mathrm{N}$ soil pool and only a third of the ${ }^{15} \mathrm{~N}(34 \%)$ from ${ }^{15} \mathrm{NH}_{4}{ }^{+}$was recovered. This supports the general notion that deciduous trees prefer nitrate in contrast to conifers which are well adapted to ammonium [16, 37, 38]. ${ }^{15} \mathrm{~N}$ recovery from $\mathrm{NH}_{4}{ }^{+}$varies in conifers from $10-65 \%{ }^{15} \mathrm{~N}$ and is always greater than $\mathrm{NO}_{3}{ }^{-}$in the initial growth period [39-41]. However, willow incorporated exactly the same amount (49\%) of ${ }^{15} \mathrm{~N}$ from both tracers and was in the range of the ${ }^{15} \mathrm{~N}$ recovery of conifers. This suggests that willow might display similar properties than conifers, i.e. not showing a nitrate preference and being able to maintain a similar good $\mathrm{N}$ nutrition independent of the $\mathrm{N}_{\min }$ source. Such ecological ability can be advantageous for a broad distribution of a species as the dominant $\mathrm{N}_{\min }$ species or a certain site does not play any role for the respective species. In consequence, for the establishment of SRC it can be stated that willows $\mathrm{N}$ nutrition is site-independent whereas poplar may suffer on sites where $\mathrm{N}_{\min }$ is predominantly existing in the ammonium form. As willow was able to take up $30 \%$ more of the applied $\mathrm{NH}_{4}{ }^{+}$than poplar, willow may be the better choice if low $\mathrm{pH}$, low temperature and poor oxygen supply cause high soil solution $\mathrm{NH}_{4}{ }^{+}$values - a management suggestions which needs be proven by field experiments. 


\subsubsection{Species-specific $\mathbf{N}$ allocation and incorporation pattern}

Both tree species allocated more than half of the incorporated ${ }^{15} \mathrm{~N}$ of both $\mathrm{N}_{\text {min }}$ species into the leaves and poplar allocated even $30 \%$ more of the assimilated ${ }^{15} \mathrm{NO}_{3}{ }^{-}$in the leaves. Leaves are highly active plant components and the high allocation of $\mathrm{N}_{\min }$-derived nitrogen into the foliar is supported by recent findings of $\mathrm{N}$ allocation patterns in trembling, hybrid aspens, Douglas fir and Scots pine $[42,43]$. The high $\mathrm{N}_{\min }$ uptake and efficient allocation into leaves of poplar might be one of the reasons for the twice as high dry matter yields of leaves in field experiments [20] confirmed by significantly higher leave dry biomass of poplar in this study (Figure 2.6-1). However this study did not include the competition caused by the differences tree stand density in willow and poplar plantations. This study was a subproject of the research program "BEST - Bioenergie-Regionen stärken" where poplar was planted with a density of 8.890 cuttings per ha and willow 11.850 cuttings per ha and this probably also relates on how the plant allocates their resources and might explain lower yield increments in individual plants in willow than in poplar [20]. For each of the two species the smallest amount of both $\mathrm{N}_{\text {min }}$-forms could be detected in the roots [44, 45] with poplar allocating only half of the ${ }^{15} \mathrm{NO}_{3}$ in the roots in comparison to willow. Although $\mathrm{NH}_{4}{ }^{+}$is frequently discussed as the less mobile $\mathrm{N}$ species not only in soil but also after plant uptake $[46,47]$ no clear evidence for that could be found in this study. Poplar shows a trend towards higher retention of $\mathrm{NH}_{4}{ }^{+}$in the roots but willow has significantly higher nitrate- than ammonium-derived $\mathrm{N}$ in its roots, despite total recovery i.e. uptake of the two $\mathrm{N}$ species was similar for willow. Immediate nitrate reduction in willow roots can also not account for the observed differences, as such an immediate reduction would cause a similar allocation pattern of nitrate and ammonium, which might be the case for poplar but not for willow. The root cortex was previously recognized as main place for the uptake of $\mathrm{NO}_{3}{ }^{-}[48]$ and some $\mathrm{NO}_{3}{ }^{-}$transporters are expressed in the epidermis [47, 49]. Both ions $\mathrm{NO}_{3}{ }^{-}$and $\mathrm{NH}_{4}{ }^{+}$get actively absorbed into root cells at low external concentrations and two high-affinity transport systems are present for $\mathrm{NO}_{3}{ }^{-}$and one high-affinity transport system for $\mathrm{NH}_{4}{ }^{+}$and the influx of both ions is responsive to plant $\mathrm{N}$ status and subject to diurnal regulation [47]. However, willow does not only seem to have uptake mechanisms enabling equal nutrition on both $\mathrm{N}_{\min }$ species but likely has also ecophysiological adaptations for an elaborated allocation of both $\mathrm{N}$ species within the plant, in case a mixed $\mathrm{N}_{\min }$-nutrition on ammonium and nitrate is possible in a certain ecosystem. Furthermore, might the higher dry matter allocation on roots in willow indicate larger yield increments in the following years relative to poplar and might be compensated along time, which may also be explanation for a partially lower $\mathrm{N}$ uptakes, as the leave system of willow seems to be less developed than the roots. Therefore experiment 
observing growth strategy over longer periods of time would give more insights in ecophysiological processes.

The overall high $\mathrm{N}$ allocation towards the leaves can be explained by the fact that canopy establishment takes precedence over root development in the first two month of the initial growth. However, the remobilization of resources seemed to be primarily a shift from leaves to stems in willow, with only a small amount being remobilized from above-ground biomass to below-ground biomass [50]. The resource investment shifts towards the stems and roots in autumn and the stem is the major $\mathrm{N}$ reserve during winter dormancy of SRC willow [50]. Our ${ }^{15} \mathrm{~N}$ pulse labeling experiment was carried out on young cuttings were the shoot to root ratios in comparison to adult trees might vary [51]. Nevertheless, poplar outgrows willow even in the first 2 month in regard to biomass production, caused by the higher $\mathrm{N}$ uptake but maybe also by its more efficient $\mathrm{N}$ allocation pattern towards the leaves. However, the lower absolute uptake rates and leave allocations of willow do not imply that willow suffers from $\mathrm{N}$ malnutrition (Table 2.6-1): Determining the relative ${ }^{15} \mathrm{~N}$ incorporation of the plant compartments' $\mathrm{N}$ pool (Figure 2.6-4), willow even exceeds poplar for most of the compartments except leaves. This suggests a sufficient supply of all plant compartments with the newly incorporated $\mathrm{N}_{\text {min }}$-derived $\mathrm{N}$ and according to Table 2.6-1 even no malnutrition in the less $\mathrm{N}$-supplied leaves.

Shoot biomass yields from short-rotation willow plantations commonly increase after the first cutting cycle and the amount of increase can vary among clones [52]. Therefore, our results cannot be transferred on the second growth of poplar or willow. Considering that $\mathrm{N}$ taken up by poplar and willow was allocated differently by both species to build up aboveground biomass, this will have consequences for $\mathrm{N}$ retention in the ecosystem after harvest. Long-term studies over entire growth periods should focus towards $\mathrm{N}$ allocation in roots or stem bases serving as permanent $\mathrm{N}$ sinks in such ecosystems versus $\mathrm{N}$ allocation in leaves, twigs and upper stem, which will get lost from the system after harvest.

\subsubsection{Criteria for selection of poplar versus willow for SRCs}

To maintain biodiversity and ecosystem functions in the face of climate change and increasing demand for wood products it is mandatory to ensure conservation and appropriate management for all wood orientated land use systems [53]. Forest are not only a major sink for atmospheric $\mathrm{CO}_{2}$ but tree species influence the storage of $\mathrm{C}$ and $\mathrm{N}$ and therefore ecosystem processes such as plant biomass production, decomposition and especially nutrient cycling [54-56]. During the last decades, the focus in forest productivity has shifted from tree and stand timber production to tree and stand biomass production, 
differentiated for all tree compartments [57]. Hence the choice of tree species for land use systems, like SRCs, is not just important for the demanded biomass production but may also play an increasing role in facing ecological challenges like climate change, loss of biodiversity and enhanced nitrogen loads, especially in agro-ecosystems. Thereby a recent study already showed that SRC may providing a substantial capacity for renewable energy from economically competitive arable sites while generating ecological synergies [36].

Not only in this pot experiment, but also in field studies balsam poplar ( $P$. trichocarpa cv. Muhle Larsen) had higher production in comparison to willow spp. and did not need any fertilization or pesticide treatment for over 10 years [58]. Choosing poplar might have further advantages as poplar wood is lighter and more brittle than willow wood, but produces fewer and heavier stems when coppiced [59], which may have a considerable impact on harvesting performance [60]. The willow cv. Tordis is very sensitive to drought especially in the first two years [20,58,61, 62], and might thus not be the appropriate choice in regions facing an increased drought. This might especially have consequences for the $\mathrm{N}$ cycle considering that rewetting after drought causes a nitrification peak and willow has the lower preference for this $\mathrm{N}$ species compared to poplar. Thus, rewetting events with strong precipitation under suffering willow stands may be followed by intensive nitrate leaching - a phenomenon which might be reduced in poplar SRC. Nevertheless, it has to be considered that ecosystems with ammonium-dominance in the soil solution may cause $\mathrm{N}$ limitation in poplar-based SRC in the initial growth period, due to the intensive preference of poplar for nitrate nutrition and might be preferred in such cases. However, most newly established SRCs are converted from former agriculturally fields, managed by annual crops and intensive fertilization, and thus displaying high nitrate concentrations in soil solution. In such a case the poplar hybrid is not only the better choice for biomass production but also to fix an excess of nitrate from arable fields. So economical production consideration may go hand in hand with ecological considerations for immobilization of a $\mathrm{N}_{\text {min }}$ surplus thereby reducing the risk of $\mathrm{N}$ leaching. This is of special importance in groundwater-endangered areas with intensive agriculture. However, differences in experimental conditions, plant nutrient status at the time of application, seedling age and stages of growth might alter the $\mathrm{N}$ cylce in SRC and requires further investigations. 


\subsubsection{Conclusion}

This pot experiment proved species-specific preferences of poplar cv. Max 1 and willow cv. Tordis for uptake but also allocation of the two $\mathrm{N}_{\min }$ species nitrate and ammonium an observation which implies consequences for management practice of SRC. Soil properties and climatic conditions need to be taken into account deciding for poplar versus willow as preferred species. So soils with high nitrification intensity, leading to strong nitrate dominance over ammonium, are better feeding the $\mathrm{N}$ nutrition preferences of poplar cv. Max 1- and as shown in this experiment lead to higher biomass yields of poplar cv. Max 1. We conclude that the poplar cv. Max 1 might be a better choice for biomass production, especially at arable sites with high $\mathrm{N}$ contents. Simultaneously planting the poplar cv. Max 1 might be the more appropriate way to prevent from all negative impacts of high soil nitrate concentrations such as $\mathrm{N}$ losses due to leaching to the groundwater or $\mathrm{N}_{2} \mathrm{O}$ emissions. This is likely to be the case for the majority of limed (high $\mathrm{pH}$ ), intensively fertilized (high $\mathrm{N}$ supply) and ploughed (high $\mathrm{O}_{2}$ supply) former agricultural fields, where SRCs are frequently established on. However, especially under the purpose of I reducing all ecological risks arising from non-closed $\mathrm{N}$ cycles as typical for classical agricultural managed sites with annual plants.,many additional ecophysiological preferences and adaptation of poplar and willow need to be taken into account and future field studies with more replicates have to demonstrate their interactions with the species-specific effects on the $\mathrm{N}$ cycle.

Therefore, we need additional information about $\mathrm{N}$ demand and $\mathrm{N}$ cycling on different sites with various soil-climatic conditions to establish practical fertilization strategies for fast growing trees like poplar and willow. However, regarding climatic changes and increasing environmental problems SRC as alternative to the depletion of fossil resources are a promising perspective. 


\subsubsection{Acknowledgements}

This study was a subproject of the research program "BEST - Bioenergie-Regionen stärken" and was funded by the Federal Ministry of Education and Research (BMBF) (033L033A), Germany. We thank the laboratory and technical staff of the Centre for Stable Isotope Research and Analysis and Soil Science of temperate Ecosystems, Georg - August University for their support. 


\subsubsection{References}

[1] Lukac M, Godbold LD. Soil Ecology in Northern Forests: A Belowground View of a Changing World: Cambridge University Press; 2011.

[2] Schulze ED. Carbon and Nitrogen Cycling in European Forest Ecosystems. Berlin, Heidelberg: Springer; 2000.

[3] van Kessel C, Clough T, van Groenigen J-W. Dissolved Organic Nitrogen: An Overlooked Pathway of Nitrogen Loss from Agricultural Systems? Journal of Environmental Quality 2009;38:393.

[4] Schmidt-Walter P, Lamersdorf NP. Biomass Production with Willow and Poplar Short Rotation Coppices on Sensitive Areas-the Impact on Nitrate Leaching and Groundwater Recharge in a Drinking Water Catchment near Hanover, Germany. BioEnergy Research 2012;5:546.

[5] Mosier AR, Doran JW, Freney JR. Managing soil denitrification. Journal of Soil and Water Conservation 2002;57:505.

[6] Friedl J, Scheer C, Rowlings DW, McIntosh HV, Strazzabosco A, Warner DI, et al. Denitrification losses from an intensively managed sub-tropical pasture - Impact of soil moisture on the partitioning of $\mathrm{N}_{2}$ and $\mathrm{N}_{2} \mathrm{O}$ emissions. Soil Biol Biochem 2016;92:58.

[7] Weih M. Intensive short rotation forestry in boreal climates: present and future perspectives. Canadian Journal of Forest Research-Revue Canadienne De Recherche Forestiere 2004;34:1369.

[8] Larsen SU, Jorgensen U, Laerke PE. Willow Yield Is Highly Dependent on Clone and Site. Bioenergy Research 2014;7:1280.

[9] Weih M, Nordh N-E. Characterising willows for biomass and phytoremediation: growth, nitrogen and water use of 14 willow clones under different irrigation and fertilisation regimes. Biomass Bioenerg 2002;23:397.

[10] Biertümpfel A, Rudel H, Werner A, A V. 15 Jahre Energieholzversuche in Thüringen. Thüringer Landesanstalt für Landwirtschaft 2009:1.

[11] Vetter A, Werner A, Reinhold G. Leitlinie zur effizienten und umweltverträglichen Erzeugung von Energieholz. Thüringer Landesanstalt für Landwirtschaft 2000;1:1.

[12] Hering T, Reinhold G, Biertümpfel A, Vetter A. Leitlinie zur effizienten und umweltverträglichen Erzeugung von Energieholz Thüringer Landesanstalt für Landwirtschaft 2013;4:1.

[13] Weih M. Evidence for increased sensitivity to nutrient and water stress in a fastgrowing hybrid willow compared with a natural willow clone. Tree Physiology $2001 ; 21: 1141$.

[14] Schulz H, Hartling S, Stange CF. Species-specific differences in nitrogen uptake and utilization by six European tree species. Journal of Plant Nutrition and Soil Science 2011;174:28.

[15] Buchmann N, Schulze ED, Gebauer G. ${ }^{15} \mathrm{~N}$ ammonium and ${ }^{15} \mathrm{~N}$ nitrate uptake of a 15-year-old Picea abies plantation. Oecologia 1995;102:361.

[16] Nadelhoffer KJ, Colman BP, Currie WS, Magill A, Aber JD. Decadal-scale fates of ${ }^{15} \mathrm{~N}$ tracers added to oak and pine stands under ambient and elevated $\mathrm{N}$ inputs at the Harvard Forest (USA). Forest Ecology and Management 2004;196:89. 
[17] Sommer J, Dippold MA, Flessa H, Kuzyakov Y. Allocation and dynamics of $\mathrm{C}$ and $\mathrm{N}$ within plant-soil system of ash and beech. Journal of Plant Nutrition and Soil Science 2016;179:376.

[18] Benesch M, Glaser B, Dippold M, Zech W. Soil microbial C and N turnover under Cupressus lusitanica and natural forests in southern Ethiopia assessed by decomposition of ${ }^{13} \mathrm{C}$ - and ${ }^{15} \mathrm{~N}$-labelled litter under field conditions. Plant Soil 2015;388:133.

[19] WRB. World Reference Base for Soil Resources 2006. Rome, Italy: FAO; 2006.

[20] Hartmann L, Richter F, Busch G, M. Ehret, Jansen M, Lamersdorf N.

Establishment of short rotation coppices in the South of Lower Saxony and in Central Thuringia in the context of the BEST-research framework - Site characteristics and initial biomass production. Forstachiv 2014;85:126.

[21] Meiwes K-J. Chemische Untersuchungsverfahren für Mineralboden, Auflagehumus und Wurzeln zur Charakterisierung und Bewertung der Versauerung in Waldböden.

Berichte des Forschungszentrums Waldökosysteme, Waldsterben 1984;7:142.

[22] Zang U, Lamersdorf N, Borken W. Response of the fine root system in a Norway spruce stand to 13 years of reduced atmospheric nitrogen and acidity input. Plant and Soil 2011;339:435.

[23] Gearing PJ, Gearing JN, Maughan JT, Oviatt CA. Isotopic distribution of carbon from sewage sludge and eutrophication in the sediments and food web of Estuarine ecosystems. Environmental Science \& Technology 1991;25:295.

[24] Gottwald W. Statistik für Anwender: WILEY-VCH Verlag GmbH; 2000.

[25] Röhricht C, Ruscher KL. Anbauempfehlungen für schnellwachsende Baumarten. Sächsische Landesanstalt für Landwirtschaft 2009:58.

[26] Werner A, Vetter A, Reinhold G. Leitlinie zur effizienten und umweltverträglichen Erzeugung von Energieholz. Thüringer Landesanstalt für Landwirtschaft Jena 2002:21.

[27] Ihl C. Schnellwachsende Baumarten auf landwirtschaftlichen Flächen in Niedersachsen. 3N-Kompetenzzentrum Niedersachsen Netzwerk Nachwachsende Rohstoffe Werlte 2010:23.

[28] Stobrawa K. Poplars (Populus spp.): Ecological Role, Applications and Scientific Perspectives in the 21st Century. Baltic Forestry 2014;20:204.

[29] Schreiber R, Eichhorn F-J. Die wirtschaftliche Situation im größeren Privat-und Körperschaftswald im Jahr 1997. LWF-aktuell 1999;17:22.

[30] Stark JM, Hart SC. High rates of nitrification and nitrate turnover in undisturbed coniferous forests. Nature 1997;385:61.

[31] Vitousek PM, Gosz JR, Grier CC, Melillo JM, Reiners WA. A comparative-analysis of potential nitrification and nitrate mobility in forest ecosystems. Ecological Monographs 1982;52:155.

[32] Eviner VT, Chapin FS. Nitrogen cycle - Plant-microbial interactions. Nature 1997;385:26.

[33] Garnett TP, Smethurst PJ. Ammonium and nitrate uptake by Eucalyptus nitens: effects of $\mathrm{pH}$ and temperature. Plant and Soil 1999;214:133.

[34] DesRochers A, van den Driessche R, Thomas BR. Nitrogen fertilization of trembling aspen seedlings grown on soils of different $\mathrm{pH}$. Canadian Journal of Forest Research 2003;33:552.

[35] Hartmann L, Lamersdorf N. Site Conditions, Initial Growth and Nutrient and Litter Cycling of Newly Installed Short Rotation Coppice and Agroforestry Systems, in Bioenergy from Dendromass for the Sustainable Development of Rural Areas. In: Manning DB, A. 
Bemmann A, Bredemeier N, Lamersdorf N, Ammer C, editors. Weinheim, Germany: Wiley-VCH Verlag GmbH \& Co. KG; 2015, p. 132.

[36] Bredemeier M, Busch G, Hartmann L, Jansen M, Richter F, Lamersdorf NP. Fast Growing Plantations for Wood Production - Integration of Ecological Effects and Economic Perspectives. Frontiers in Bioengineering and Biotechnology 2015;3:1.

[37] Min X, Siddiqi MY, Guy RD, Glass ADM, Kronzucker HJ. Induction of nitrate uptake and nitrate reductase activity in trembling aspen and lodgepole pine. Plant, Cell \& Environment 1998;21:1039.

[38] Kronzucker HJ, Siddiqi MY, Glass ADM. Conifer root discrimination against soil nitrate and the ecology of forest succession. Nature 1997;385:59.

[39] Lamontagne S, Schiff SL, Elgood RJ. Recovery of ${ }^{15} \mathrm{~N}$-labelled nitrate applied to a small upland boreal forest catchment. Canadian Journal of Forest Research 2000;30:1165.

[40] Islam MA, Macdonald SE. Current uptake of ${ }^{15} \mathrm{~N}$-labeled ammonium and nitrate in flooded and non-flooded black spruce and tamarack seedlings. Annals of Forest Science 2009;66:102.

[41] Salifu KF, Timmer VR. Nitrogen Retranslocation Response of Young Picea mariana to Nitrogen-15 Supply. Soil Science Society of America Journal 2003;67:309.

[42] Koopmans CJ, Tietema A, Boxman AW. The fate of ${ }^{15} \mathrm{~N}$ enriched throughfall in two coniferous forest stands at different nitrogen deposition levels. Biogeochemistry 1996;34:19.

[43] Choi W-J, Chang SX, Hao X. Soil retention, tree uptake, and tree resorption of ${ }^{15} \mathrm{NH}_{4} \mathrm{NO}_{3}$ and $\mathrm{NH}_{4}{ }^{15} \mathrm{NO}_{3}$ applied to trembling and hybrid aspens at planting. Canadian Journal of Forest Research 2005;35:823.

[44] Muñoz N, Guerri J, Legaz F, Primo-millo E. Seasonal uptake of 15N-nitrate and distribution of absorbed nitrogen in peach trees. Plant and Soil 1993;150:263.

[45] Mugasha AG, Pluth DJ. Distribution and recovery of ${ }^{15} \mathrm{~N}$-urea in a tamarack/black spruce mixed stand on a drained minerotrophic peatland. Forest Ecology and Management 1994;68:353.

[46] Ghaly AE, Ramakrishnan VV. Nitrogen Sources and Cycling in the Ecosystem and its Role in Air, Water and Soil Pollution: A Critical Review. Journal of Pollution Effects and Control 2015;3:136.

[47] Glass ADM, Britto DT, Kaiser BN, Kinghorn JR, Kronzucker HJ, Kumar A, et al. The regulation of nitrate and ammonium transport systems in plants. Journal of Experimental Botany 2002;53:855.

[48] Siddiq MY, Glass ADM, Ruth TJ. Journal of Experimental Botany. 1991;42:1455.

[49] Robinson D. Resource capture by localized root proliferation: Why do plants bother? Annals of Botany 1996;77:179.

[50] Brereton NJB, Pitre FE, Shield I, J. SJHS, Ray MJ, Murphy JR, et al. Insights into nitrogen allocation and recycling from nitrogen elemental analysis and ${ }^{15} \mathrm{~N}$ isotope labelling in 14 genotypes of willow. Tree Physiology 2013;00:1.

[51] Gessler A, Schneider S, Von Sengbusch D, Weber P, Hanemann U, Huber C, et al. Field and laboratory experiments on net uptake of nitrate and ammonium by the roots of spruce (Picea abies) and beech (Fagus sylvatica) trees. New Phytologist 1998;138:275.

[52] Hytonen J. 10-year biomass production and stand structure of Salix aquaica energy forest plantation in Southern Finland. Biomass Bioenerg 1995;8:63. 
[53] Schulze ED, Aas G, Grimm GW, Gossner MM, Walentowski H, Ammer C, et al. A review on plant diversity and forest management of European beech forests. European Journal of Forest Research 2016;135:51.

[54] Heinrich S, Dippold MA, Werner C, Wiesenberg GL, Kuzyakov Y, Glaser B. Allocation of freshly assimilated carbon into primary and secondary metabolites after in situ ${ }^{13} \mathrm{C}$ pulse labelling of Norway spruce (Picea abies). Tree Physiology 2015;35:1176.

[55] Gamfeldt L, Hillebrand $\mathrm{H}$, Jonsson PR. Multiple functions increase the importance of biodiversity for overall ecosystem functioning. Ecology 2008;89:1223.

[56] Hooper DU, Chapin FS, Ewel JJ, Hector A, Inchausti P, Lavorel S, et al. Effects of biodiversity on ecosystem functioning: A consensus of current knowledge. Ecological Monographs 2005;75:3.

[57] Parresol BR. Assessing tree and stand biomass: A review with examples and critical comparisons. Forest Science 1999;45:573.

[58] Hofmann-Schielle C, Jug A, Makeschin F, Rehfuess KE. Short-rotation plantations of balsam poplars, aspen and willows on former arable land in the Federal Republic of Germany. I. Site-growth relationships. Forest Ecology and Management 1999;121:41.

[59] Tharakan PJ, Volk TA, Abrahamson LP, White EH. Energy feedstock characteristics of willow and hybrid poplar clones at harvest age. Biomass Bioenerg 2003;25:571.

[60] Spinelli R, Nati C, Magagnotti N. Using modified foragers to harvest short-rotation poplar plantations. Biomass Bioenerg 2009;33:817.

[61] Weih M, Nordh N-E. Characterising willows for biomass and phytoremediation: growth, nitrogen and water use of 14 willow clones under different irrigation and fertilisation regimes. Biomass and Bioenergy 2002;23:397.

[62] Weih M, Nordh NE. Determinants of biomass production in hybrid willows and prediction of field performance from pot studies. Tree Physiology 2005;25:1197. 


\title{
2.6.8 Supplementary material
}

\author{
Supplementary material for
}

\section{Specific Nmin uptake patterns of two widely applied poplar and willow clones for short rotation coppieses - implications for management practices}

\author{
Biomass and Bioenergy \\ Janine Sommer ${ }^{1^{*}}$, Michaela Dippold ${ }^{2}$, Heiz Flessa ${ }^{3}$, Yakov Kuzyakov ${ }^{1,2}$
}

1 Soil Science of Temperate Ecosystems, University of Göttingen 37077 Göttingen, Germany

2 Agricultural Soil Science, Georg-August-University Göttingen, 37077 Göttingen, Germany

${ }^{3}$ Institute of Climate-Smart Agriculture, Thünen Institute, 38116 Braunschweig, Germany

Email of the corresponding author*: sommer.janine@yahoo.de 
Table 2.6-3: T-test for independent samples of results for the ${ }^{15} \mathrm{~N}$ recovery of the applied tracer and their differences between tree species and between the $N_{\text {min }}{ }^{-}$ species in poplar cv. Max 1 and willow cv. Tordis of different plant compartments.

Source of variation

Degrees of Significance (t-value) Freedom level

(df)

(p)

\section{Leaves}

Between poplar and willow, ${ }^{15} \mathrm{NO}_{3}^{-}$ $-23.23$

5

0.00

Between poplar and willow, ${ }^{15} \mathrm{NH}_{4}{ }^{+}$

0.86

6

0.42

Between ${ }^{15} \mathrm{~N}_{\min }$-species in poplar

8.76

5

0.00

Between ${ }^{15} \mathrm{~N}_{\min }$-species in willow

$-0.37$

6

0.73

\section{Twigs}

Between poplar and willow, ${ }^{15} \mathrm{NO}_{3}{ }^{-}$

0.23

5

0.83

Between poplar and willow, ${ }^{15} \mathrm{NH}_{4}{ }^{+}$

3.11

6

0.02

Between ${ }^{15} \mathrm{~N}_{\text {min }}$-species in poplar

3.73

6

0.01

Between ${ }^{15} \mathrm{~N}_{\min }$-species in willow

1.52

5

0.19

\section{Stem}

Between poplar and willow, ${ }^{15} \mathrm{NO}_{3}{ }^{-}$

Between poplar and willow, ${ }^{15} \mathrm{NH}_{4}{ }^{+}$

Between ${ }^{15} \mathrm{~N}_{\text {min }}$-species in poplar

Between ${ }^{15} \mathrm{~N}_{\min }$-species in willow

\section{Root}

Between poplar and willow, ${ }^{15} \mathrm{NO}_{3}{ }^{-}$

0.56

6

0.60

Between poplar and willow, ${ }^{15} \mathrm{NH}_{4}{ }^{+}$

$-0.59$

5

0.58

Between ${ }^{15} \mathrm{~N}_{\text {min }}$-species in poplar

0.19

6

0.86

Between ${ }^{15} \mathrm{~N}_{\min }$-species in willow

2.65

5

0.05 
Table 2.6-4: T-test for independent samples of results for the ${ }^{15} \mathrm{~N}$ allocation of assimilated tracer and their differences between tree species and between the $N_{\text {min }}$-species in poplar cv. Max 1 and willow cv. Tordis of different plant compartments.

Source of variation

Degrees of Freedom

(df)
Significance level

(p)

\section{Leaves}

Between poplar and willow, ${ }^{15} \mathrm{NO}_{3}{ }^{-}$

Between poplar and willow, ${ }^{15} \mathrm{NH}_{4}{ }^{+}$

Between ${ }^{15} \mathrm{~N}_{\min }$-species in poplar

0.73

5

Between ${ }^{15} \mathrm{~N}_{\text {min }}$-species in willow

\section{Twigs}

Between poplar and willow, ${ }^{15} \mathrm{NO}_{3}{ }^{-}$

Between poplar and willow, ${ }^{15} \mathrm{NH}_{4}{ }^{+}$

Between ${ }^{15} \mathrm{~N}_{\text {min }}$-species in poplar

Between ${ }^{15} \mathrm{~N}_{\min }$-species in willow

\section{Stem}

Between poplar and willow, ${ }^{15} \mathrm{NO}_{3}{ }^{-}$

Between poplar and willow, ${ }^{15} \mathrm{NH}_{4}{ }^{+}$

Between ${ }^{15} \mathrm{~N}_{\text {min }}$-species in poplar

Between ${ }^{15} \mathrm{~N}_{\text {min }}$-species in willow

\section{Root}

Between poplar and willow, ${ }^{15} \mathrm{NO}_{3}{ }^{-}$

Between poplar and willow, ${ }^{15} \mathrm{NH}_{4}{ }^{+}$

Between ${ }^{15} \mathrm{~N}_{\text {min }}$-species in poplar 
Table 2.6-5: T-test for independent samples of results for the ${ }^{15} \mathrm{~N}$ incorporation of the $N$ pool and their differences between tree species and between the $N_{\text {min }}{ }^{-}$ species in poplar cv. Max 1 and willow cv. Tordis of different plant compartments.

Source of variation

Degrees of Freedom

(df)
Significance level

(p)

\section{Leaves}

Between poplar and willow, ${ }^{15} \mathrm{NO}_{3}{ }^{-}$

Between poplar and willow, ${ }^{15} \mathrm{NH}_{4}{ }^{+}$

0.72

6

0.50

Between ${ }^{15} \mathrm{~N}_{\text {min }}$-species in poplar

Between ${ }^{15} \mathrm{~N}_{\mathrm{min}}$-species in willow

$-6.16$

6

0.00

\section{Twigs}

Between poplar and willow, ${ }^{15} \mathrm{NO}_{3}{ }^{-}$

Between poplar and willow, ${ }^{15} \mathrm{NH}_{4}{ }^{+}$

Between ${ }^{15} \mathrm{~N}_{\text {min }}$-species in poplar

Between ${ }^{15} \mathrm{~N}_{\min }$-species in willow

\section{Stem}

Between poplar and willow, ${ }^{15} \mathrm{NO}_{3}{ }^{-}$

Between poplar and willow, ${ }^{15} \mathrm{NH}_{4}{ }^{+}$

Between ${ }^{15} \mathrm{~N}_{\text {min }}$-species in poplar

Between ${ }^{15} \mathrm{~N}_{\min }$-species in willow

\section{Root}

Between poplar and willow, ${ }^{15} \mathrm{NO}_{3}{ }^{-}$

Between poplar and willow, ${ }^{15} \mathrm{NH}_{4}{ }^{+}$

Between ${ }^{15} \mathrm{~N}_{\min }$-species in poplar

Between ${ }^{15} \mathrm{~N}_{\text {min }}$-species in willow 


\section{Acknowledgements}

I sincerely thank my supervisor Prof. Dr. Y. Kuzyakov for offering this very interesting research topic and for giving me the opportunity for this dissertation. Yakov, you were always fair and I very much appreciate your positive attitude. I will never forget your quote "There are no problems just solutions!". Thank you very much!

Special thanks go to Dr. M. Dippold, who well supported Yakov with the supervision. Michaela, your door was always open whenever I needed professional advice. Thank you!

I also want to show my gratitude to A. Handke and M. Holz for conducting their Bachelor thesis with me. Without their help it would have never been possible to finish this work. Furthermore, I have been supported by an outstanding student assistant in the lab, A. Meyer and the generous strong helping hands of $\mathrm{K}$. Schünke in the forest. Furthermore, I thank S. Zieger and R. Thoms for their teamwork in joint experiments.

I thank my colleagues from the PGZ, PTS and Agricultural Soil Science. I felt well integrated because of colleagues like C. Apostel, K. Langs, A. Kriegel, S. Grube. And special thanks to I. Ostermeyer and S. Enzmann who always provided me with the little things and words I needed most. I would also like to thank Dr. P. Gernandt, Dr C. Ahl, Dr. F. Richter, Prof. Dr. N. Lamersdorf, Dr. M. Jansen and C. Döring, Dr. N. Loftfield, D. Böttger for the ever-open door, and that you stood by me with advice and technical support.

Some of the labeling was done in cooperation with the Labor für Radioisotopes. I sincerely thank Prof. Dr. A. Polle, T. Klein and especially B. Kopka, who were always there to help when technical problems arose. I have also produced a vast number of samples and the staff of the Kosi always dealt with them quickly and reliably: Thank you to Dr. J. Dyckmans, R. Langel, E. Pommerening-Dehnhard and L. Szwec.

Last but not least I also want to thank my doctoral committee, Prof. Dr. Ammer and Prof. Dr. Scherber for their support and especially Prof. Dr. A. Carminati for being my second referee. I thank the DFG for the funding of my project and the National Park Service for the opportunity to research in the Hainich. 


\section{Curriculum Vitae}

\section{SOMMER JANINE}

Personal Information

Date of Birth: 03/22/1978

Place of Birth: Querfurt

Marital status: Single

PH. D. Studies

Since 06/2011

Ph. D. studies at the Department of Soil Science of Temperate Ecosystems, Georg-August-University, Göttingen, Germany

GRANDS

Under supervision of Prof. Dr. Y. Kuzyakov

08.2014

$06.2011-05.2014$

$06.2011-05.2014$

$10.2008-12.2008$

$12.2007-03.2008$

HigER EDUCATION

$10.2004-05.2010$

$07.2007-11.2008$

12.2010

$09.1996-07.1999$
Congress Travel Grant IsoEcol, Perth, Australia, donated by Georg-August University

Research Grant donated by Deutschen

Forschungsgemeinschaft

Congress Travel Grant Eurosoil, Bari, Italy, donated by Deutscher Akademischer Austauschdienst (DAAD)

Research Grant donated by Deutscher Akademischer Austauschdienst

Research Grant of the Biodiversity Conservation Centre, Kings Park and Botanic Garden, Perth, Australia

Studies of Biology, University Bayreuth, Germany

Studies of Conservation Biology and Biodiversity, University of Western Australia, Australia

Science degree at the Department of Isotope

Biogeochemistry, University of Bayreuth, Germany Title of Diploma Thesis: „Carbon and nitrogen sources and fungal partners of selected Western Australian orchids",

Technical School of Physiotherapy, Novum Bildung und Wissen $\mathrm{GmbH}$, Germany 


\begin{tabular}{|c|c|}
\hline $09.1984-07.1991$ & Primary School, Querfurt \\
\hline $09.1991-06.1996$ & Secondary School, Gymnasium Querfurt, \\
\hline 06.1996 & Higher Education Entrance Qualification, Abitur \\
\hline EMPLOYMENT HISTORY & DURING THE ACADEMIC PERIOD \\
\hline $10.2015-06.2016$ & Physiotherapist, Praxis Sandra Rose, Kranichfeld, Germany \\
\hline 09.2015 & Physiotherapist, SLL-W Studio, Querfurt, Germany \\
\hline $10.2014-02.2015$ & $\begin{array}{l}\text { Consultant at Association of Statutory Health Insurance } \\
\text { Physicians, Leipzig, Germany }\end{array}$ \\
\hline $06.2014-09.2014$ & Physiotherapist, SLL-W Studio, Querfurt, Germany \\
\hline $07.2011-02.2012$ & $\begin{array}{l}\text { Student Assistant at the Department of Soil Science of } \\
\text { Temperate Ecosystems, Georg-August-University Göttingen, } \\
\text { Germany }\end{array}$ \\
\hline $01.2011-05.2011$ & $\begin{array}{l}\text { Research Assistant at the Department of Animal Ecology, } \\
\text { Philipps-University Marburg, Germany }\end{array}$ \\
\hline $04.2005-02.2010$ & $\begin{array}{l}\text { Student Assistant at the Department of Plant Ecology, } \\
\text { Ecological Botanical Gardens, Chair for Process } \\
\text { Biotechnology; Laboratory of Isotope Biochemistry; Soil } \\
\text { Physics Group; a total of over } 780 \text { h, University Bayreuth, } \\
\text { Germany }\end{array}$ \\
\hline $07.2009-08.2009$ & $\begin{array}{l}\text { Student Assistant at the Student Assistant at Royal Botanic } \\
\text { Gardens, Kew, United Kingdom }\end{array}$ \\
\hline $12.2007-03.2008$ & $\begin{array}{l}\text { Research Assistant at Kings Park, Botanic Gardens, Perth, } \\
\text { Australia }\end{array}$ \\
\hline & \\
\hline
\end{tabular}

How to write a review paper, Bayreuth, Germany (28.01. - 01.02. 2013)

Successful and Authentic Self Presentation, Göttingen, Germany (14.09.2012)

Central European Meeting for Isotope Users, Bremen, Germany (16. - 17.12.2013

\section{PUPLICATIONS}

Sommer,J., Hartmann, L., Dippold, M.A., Lamersdorf, N.P. (2017). Specific $N_{\min }$ uptake patterns of two widely applied poplar and willow clones for short rotation coppices Implications for management practices Biomass and Bioenergy, 98, 236-242.

Sommer, J., Dippold, M.A., Flessa, H., Kuzyakov,Y. (2016). Allocation and dynamics of C and $\mathrm{N}$ within plant-soil system of ash and beech. Journal of Plant and Soil Science 179, 376-387 
Sommer, J., Pausch, J., Brundrett, M.C., Dixon, K.W., Bidartondo, M.I. and Gebauer, G. (2012). Limited carbon and mineral nutrient gain from mycorrhial fungi by adult Australian orchids. American Journal of Botany 99, 1133-1145.

Sommer, J., Dippold, M.A., Kuzyakov,Y. (2017). How to decide the nitrogen leave labeling tracer for broadleaved trees. Journal of Plant and Soil Science (Minor revisions)

Sommer, J., Davis, B., Lim, W.-H., Gube, M., Kuzyakov, Y., Dixon, K.W. (2017). Mechanisms of phosphate acquisition by mycorrhiza. Submitted to Mycological Progress

Zieger, S.L., Holczinger, A., Sommer, J., Rath, M., Kuzyakov, Y., Polle, A., Maraun, M., Scheu, S. (2017) Beech trees fuel soil animal food webs via root-derived nitrogen. Submitted to Basic and Applied Ecology

\section{Oral Presentations}

Sommer, J., Kuzyakov, Y. (2014). The effect of tree species on the carbon and nitrogen allocation in forest soil. International Conference on Applications of Stable Isotope Techniques to Ecological Studies, Perth, Australia (05.08.2014)

Sommer, J., Dixon, K., Bidartondo, M., Gebauer, G. (2012). Stable isotopes in orchid mycorrhiza associations. Workshop "Application of Stable Isotopes in Hydrological Studies and plant ecology", Gunung Walat University Forest, Indonesia (02.12.2012)

Sommer, J., Kuzyakov, Y. (2012). Is there a tree-species effect on the carbon an nitrogen cycle in the soil of a deciduous forest?. Joint Workshop on Biodiversity Research, Institute Pertanian Bogor, Indonesia (30.11.2012)

Sommer, J., Dixon, K., Bidartondo, M., Gebauer, G. (2010). Carbon and nitrogen sources and fungal partners of selected Western Australian orchids. ETH Zürich, Switzerland (8.12.2010)

\section{Poster Presentations}

Sommer, J., Kuzyakov, Y. (2012). Translocation of $\mathrm{C}$ and $\mathrm{N}$ to forest soils as affected by Fraxinus excelsior L. and Fagus sylvatica L.. Joint European Stable Isotope Users group meeting, Leipzig, Germany (03. - 07.09.2012)

Sommer, J., Kuzyakov, Y. (2012). Effects of tree diversity on transformation and translocation of carbon and nitrogen in forest soil. International Congress of the European Confederation of soil science societies, Bari, Italy (02. - 06.06.2012)

Sommer, J., Dixon, K., Bidartondo, M., Gebauer, G. (2010). Myco-heterotrophy in selection of Australian orchids. International conference for Genetic and isotopic fingerprinting methods practical tools to verify the declared origin of wood, Eschborn, Germany (03. - 04.11.2010)

Sommer, J., Dixon, K., Bidartondo, M., Gebauer, G. (2009). Myco-heterotrophy in selection of Australian orchids. Ecological Society meeting, Bayreuth, Germany (14. - 18.09.2009) 
Sommer, J., Dixon, K., Bidartondo, M., Gebauer, G. (2009). Myco-heterotrophy in selection of Australian orchids. German Association for Stable Isotope Research, Postdam, Germany (05. - 07.10.2009)

\section{Declaration of originality and certificate of authorship}

I, Janine Sommer, hereby declare, to the best of my knowledge and belief, that this thesis contains no material previously published or written by another person, except where due reference has been made in the text of the thesis. I furthermore declare that this work has not been submitted elsewhere in any form as part of another dissertation procedure.

\section{Erklärung}

Hiermit erkläre ich, die vorliegende Arbeit selbst verfasst, keine anderen als die angegebenen Quellen und Hilfsmittel benutzt sowie alle wörtlich und sinngemäß übernommenen Stellen in der Arbeit gekennzeichnet zu haben. Ferne erkläre ich, dass ich nicht anderweitig mit oder ohne Erfolg versucht habe, eine Dissertation einzureichen oder mich einer Doktorprüfung zu unterziehen. 